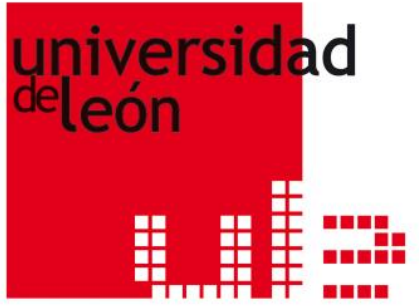

\title{
APLICACIONES DE LA BIOFOTÓNICA A LA TERAPÉUTICA DE LEISHMANIA
}

ESTEFANÍA CALVO ÁLVAREZ DPTO. CIENCIAS BIOMÉDICAS ÁREA DE TOXICOLOGÍA LEÓN, SEPTIEMBRE DE 2014 



\section{ÍNDICE}

ABREVIATURAS $\quad 4$

\begin{tabular}{lr} 
RESUMEN & 11 \\
\hline
\end{tabular}

\begin{tabular}{lr} 
SUMMARY & 14 \\
\hline
\end{tabular}

REVISIÓN BIBLIOGRÁFICA $\quad 19$

1.1. LAS ENFERMEDADES INFECCIOSAS: PASADO, PRESENTE Y FUTURO 19

1.1.1. INFECCIONES PARASITARIAS: LOS PRIMEROS ESCRITOS 21

1.1.2. VISIÓN HISTÓRICA DE LA LEISHMANIOSIS

1.2. LAS ENFERMEDADES TROPICALES DESATENDIDAS (ETDS) 25

1.3. LEISHMANIOSIS $\quad \mathbf{2 7}$

1.3.1. EPIDEMIOLOGÍA DE LA ENFERMEDAD Y PRINCIPALES FACTORES DE RIESGO 27

1.3.2. DIAGNÓSTICO, PREVENCIÓN Y TRATAMIENTO DE LA LEISHMANIOSIS 30

1.3.3. SITUACIÓN DE LA LEISHMANIOSIS EN ESPAÑA 31

1.4. EL GÉNERO LEISHMANIA

1.4.1. CICLO BIOLÓGICO DE LEISHMANIA SPP.

1.4.2. LEISHMANIOSIS: FORMAS CLÍNICAS DE LA ENFERMEDAD

1.5. RELACIÓN PARÁSITO-HOSPEDADOR $\mathbf{5 2}$

1.5.1. MECANISMOS DE EVASIÓN PARASITARIA EN EL VECTOR INVERTEBRADO

1.5.2. RESPUESTA INMUNE Y EVASIÓN EN EL HOSPEDADOR DEFINITIVO

1.6. INMUNOPATOGÉNESIS DE LA LEISHMANIOSIS: MODELOS ANIMALES 58

1.7. TRATAMIENTO DE LA LEISHMANIOSIS Y APARICIÓN DE RESISTENCIAS $\mathbf{6 4}$

1.7.1. QUIMIOTERAPIA ACTUAL Y PASADA 65

1.7.2. NUEVAS DIANAS TERAPÉUTICAS

1.7.3. CO-INFECCIÓN LV Y VIH

1.7.4. VACUNAS CONTRA LA LEISHMANIOSIS

1.8. LA BIOFOTÓNICA EN EL ESTUDIO DE LA LEISHMANIOSIS $\mathbf{7 6}$

1.8.1. REPORTEROS FLUORESCENTES VS. BIOLUMINISCENTES 76

1.8.2. GENERACIÓN DE CEPAS MODIFICADAS DE LEISHMANIA QUE SOBREEXPRESAN GENES
FLUORESCENTES O BIOLUMINISCENTES

1.8.3. EVOLUCIÓN DE LAS PROTEÍNAS FLUORESCENTES

1.9. EMPLEO DE PARÁSITOS TRANSGÉNICOS PARA EL DESCUBRIMIENTO Y EL DESARROLLO DE NUEVOS FÁRMACOS CONTRA LA LEISHMANIOSIS 88

1.9.1. ESTUDIOS HTS EN LEISHMANIA

1.9.2. EMPLEO DE PARÁSITOS TRANSGÉNICOS EN INFECCIONES IN VIVO DE IMAGEN A TIEMPO REAL 91

1.10. INTERCAMBIO GENÉTICO EN TRIPANOSOMÁTIDOS 93

1.10.1. ¿TEORÍA CLONAL O REPRODUCCIÓN SEXUAL? 94

1.10.2. PLOIDÍA E INTERCAMBIO GENÉTICO EN LEISHMANIA 95

1.10.3. EMPLEO DE CEPAS FLUORESCENTES EN ESTUDIOS DE INTERCAMBIO GENÉTICO 97

\begin{tabular}{lr} 
OBJETIVOS & 102 \\
\hline
\end{tabular}

\begin{tabular}{lr} 
ARTÍCULO 1 & 105 \\
\hline
\end{tabular}

\begin{tabular}{lr} 
ARTÍCULO 2 & 115 \\
\hline
\end{tabular}

\begin{tabular}{lr} 
ARTÍCULO 3 & 128 \\
\hline
\end{tabular}

RESULTADOS Y DISCUSIÓN $\quad 140$ 
1.1. ARTÍCULO 1: “GIMATECAN AND OTHER CAMPTOTHECIN DERIVATIVES POISON LEISHMANIA DNA-TOPOISOMERASE IB LEADING TO A STRONG LEISHMANICIDAL EFFECT"

1.2. ARTÍCULO 2: “APPRAISAL OF A LEISHMANIA MAJOR STRAIN STABLY EXPRESSING MCHERRY FLUORESCENT PROTEIN FOR BOTH IN VITRO AND IN VIVO STUDIES OF POTENTIAL DRUGS AND VACCINE AGAINST CUTANEOUS LEISHMANIASIS"

1.3. ARTÍCULO 3: "FIRST EVIDENCE OF INTRACLONAL GENETIC EXCHANGE IN TRYPANOSOMATIDS USING TWO LEISHMANIA INFANTUM FLUORESCENT TRANSGENIC CLONES"

1.1. ARTÍCULO 1: “GIMATECAN AND OTHER CAMPTOTHECIN DERIVATIVES POISON LEISHMANIA DNA-TOPOISOMERASE IB LEADING TO A STRONG LEISHMANICIDAL EFFECT"

1.2. ARTÍCULO 2: “APPRAISAL OF A LEISHMANIA MAJOR STRAIN STABLY EXPRESSING MCHERRY FLUORESCENT PROTEIN FOR BOTH IN VITRO AND IN VIVO STUDIES OF POTENTIAL DRUGS AND VACCINE AGAINST CUTANEOUS LEISHMANIASIS"

1.3. ARTÍCULO 3: "FIRST EVIDENCE OF INTRACLONAL GENETIC EXCHANGE IN TRYPANOSOMATIDS USING TWO LEISHMANIA INFANTUM FLUORESCENT TRANSGENIC CLONES”

1.1. ARTICLE 1: “GIMATECAN AND OTHER CAMPTOTHECIN DERIVATIVES POISON LEISHMANIA DNA-TOPOISOMERASE IB LEADING TO A STRONG LEISHMANICIDAL EFFECT"

1.2. ARTICLE 2: "APPRAISAL OF A LEISHMANIA MAJOR STRAIN STABLY EXPRESSING MCHERRY FLUORESCENT PROTEIN FOR BOTH IN VITRO AND IN VIVO STUDIES OF POTENTIAL DRUGS AND VACCINE AGAINST CUTANEOUS LEISHMANIASIS" 1.3. ARTICLE 3: "FIRST EVIDENCE OF INTRACLONAL GENETIC EXCHANGE IN TRYPANOSOMATIDS USING TWO LEISHMANIA INFANTUM FLUORESCENT TRANSGENIC CLONES" 



\section{ABREVIATURAS}

a.C. antes de Cristo

ABC Transportador de Unión al Casette de ATP

ADN Ácido Desoxirribonucleico

APCs Células Presentadoras de Antígeno

Ara Arabinosa

ARNm Ácido Ribonucleico mensajero

ARNr Ácido Ribonucleico ribosomal

ATP Adenosín Trifosfato

BCG Bacilo Calmette-Guerin

BFP Proteína Fluorescente Azul

BphPs Bacteriofitocromos

BT1 Transportador de Biopterina 1

camCB Gen de la Calmodulina A

CBD Dominio de Unión al Cromóforo

CC50 $_{50} \quad$ Concentración Citotóxica 50

CCD Dispositivo de Carga Acoplada

CCL2 Factor Quimiotáctico 2

CFP Proteína Fluorescente Cian

CL1 Banda de "cleavage" 1

CPA Cisteín Proteinasa A

CR1 Receptor del Complemento 1

Ct Dominio C-terminal

CTL Linfocito T Citotóxico

d.C. Después de Cristo

DC Célula Dendrítica

DHFR Dihidrofolato Reductasa

DMSO Dimetilsulfóxido

DNDi Drugs for Neglected Diseases initiative

DTT Ditiotreitol

EDs Enfermedades Desatendidas

EDTA Ácido Etildiaminotetraacético

EGFP Proteína Fluorescente Verde Aumentada 


\begin{tabular}{|c|c|}
\hline $\mathbf{E P}$ & Sonda Externa \\
\hline ESTs & Marcador de Secuencia Expresada \\
\hline ETDs & Enfermedades Tropicales Desatendidas \\
\hline FACS & Clasificación de Células Activadas por Fluorescencia \\
\hline FCS/FBS & Suero Fetal Bovino \\
\hline FISH & Hibridación Fluorescente In Situ \\
\hline FRET & Transmisión de Energía de Resonancia \\
\hline Gal & Galactosa \\
\hline GFP & Proteína Fluorescente Verde \\
\hline GIPLs & Lípidos del ácido Glicofosfatidilinositol \\
\hline Gly & Glicina \\
\hline $\mathbf{H b}$ & Hemoglobina \\
\hline HbO & Oxihemoglobina \\
\hline HbR & Receptor de Hemoglobina \\
\hline HCS & Cribado de Alto Contenido \\
\hline HEPES & Ácido 4-(2-hidroxietil)-1-piperazinetanosulfónico \\
\hline His & Histidina \\
\hline HMGs & Genes Homólogos de Meiosis \\
\hline Hsp70 & Proteína de Choque Térmico 70 \\
\hline HTS & Cribado de Alto Rendimiento \\
\hline $\mathbf{I}+\mathrm{D}+\mathbf{i}$ & Investigación, Desarrollo e Innovación \\
\hline $\mathbf{I C}_{50}$ & Concentración Inhibitoria 50 \\
\hline ICAM-1 & Molécula de Adhesión Intercelular 1 \\
\hline IFN- $\gamma$ & Interferón gamma \\
\hline IL-6 & Interleucina 6 \\
\hline iNOS & Óxido Nítrico Síntasa inducible \\
\hline IPK & Instituto Pasteur de Korea \\
\hline ISPF & 1-Fenil-1,2-propanodiona-2-oxima \\
\hline ISPs & Inhibidores de Serin-proteasas \\
\hline JAK & Quinasa de Janus \\
\hline L-Amb & Anfotericina B liposomal \\
\hline LAMP-1 & Proteína de Membrana Asociada al Lisosoma 1 \\
\hline LC & Leishmaniosis Cutánea \\
\hline LD & Desequilibrio de Ligamiento \\
\hline LDA & Ensayo de Dilución Límite \\
\hline
\end{tabular}


LDAU Unidades del Ensayo de Dilución Límite

LDC Leishmaniosis Difusa Cutánea

LdMT Transportador de Miltefosina de Leishmania donovani

LDPK Leishmaniosis Dérmica Post Kala-azar

LIT1 Transportador de Hierro de Leishmania 1

LMC Leishmaniosis Mucocutánea

LmSTI1 Factor de Iniciación de Elongación 1 de Leishmania major

LOH Pérdida de Heterozigosis

LPG Lipofosfoglicano

LPS Lipopolisacárico

LV Leishmaniosis Visceral

Lys Lisina

LYST Proteína de Tráfico Lisosomal

MA Antimonio de Meglumina

Man Manosa

MAPK Quinasas Activadas por Mitógenos

MDR1 Gen de la Proteína de Resistencia a Multifármacos

NNN Medio Neal, Nory y Nicolle

Met Metionina

MF Miltefosina

MHC Complejo Mayor de Histocompatibilidad

MP Matriz Peritrófica

mRFP Proteína Fluorescente Roja monomérica

MSF Médicos sin Fronteras

MTs Tipos de Cruzamiento

NADPH Nicotinamida Adenina Dinucleótido Fosfato

NO Óxido Nítrico

Nt Dominio N-terminal

OMS Organización Mundial de la Salud

ONGs Organizaciones No Gubernamentales

ORF Marco de Lectura Abierto

PBS Tampón Fosfato Salino

PCE Evolución Clonal Predominante

PCR Reacción en Cadena de la Polimerasa 
PIB Producto Interior Bruto

pLEXSY Sistema de Expresión en Leishmania

PM Paromomicina

PMA Forbol 12-miristato 13-acetato

PPG Proteofosfoglicano

PTR1 Pteridín Reductasa

RFLPs Polimorfismos de Longitud de Fragmentos de Restricción

rhIL-12 Citoquina Humana Recombinante IL-12

rHuGM-CSF Factor de Crecimiento Humano Recombinante y Factor Estimulante de Colonias de Granulocito/Monocito

ROI Región de Interés

ROS Especies Reactivas de Oxígeno

sAP Fosfatasa Ácida secretada

SARS Síndrome Respiratorio Agudo Severo

SCID Inmunodeficiencia Severa Combinada

SCMT S-adenosil-l-methionina:C-24- $\Delta$-sterol-metiltransferasa

SDS Dodecil Sulfato Sódico

Ser Serina

SHM Hipermutación Somática

SI Índice Selectivo

SIDA Síndrome de Inmunodeficiencia Adquirida

SNPs Polimorfismos de Nucleótido Simple

SOCS-1 Proteína Supresora de la Señalización de Citocinas 1

spp Especie

SPPG Proteofosfoglicano secretado

SSG Estibogluconato de Sodio

STAT Proteína de Señal de Transducción y Transcripción

TAD Test de Aglutinación Directa

TARGA Terapia Antirretroviral de Gran Actividad

Tet Tetraciclina

TGF- $\beta$ Factor de Crecimiento Transformante beta

Th1, Th2 Linfocitos T "helper" 1 y 2

Thr Treonina

TLR Receptores de tipo Toll

TNF- $\boldsymbol{\alpha} \quad$ Factor de Necrosis Tumoral alfa 
TopIA Topoisomerasa IA

TopIB Topoisomerasa IB

TSA Antioxidante Específico de Tiol

Tyr Tirosina

Tyr222 Tirosina 222

UTRs Regiones no Traducidas

VCAM-1 Molécula de Adhesión Vascular 1

VIH Virus de la Inmunodeficiencia Adquirida Humana

wpi Semanas Post-Infección

WT Cepa Silvestre

YFP Proteína Fluorescente Amarilla

Zn Zinc 



\section{RESUMEN}




\section{RESUMEN}

Los protozoos de la Familia Trypanosomatidae son parásitos unicelulares responsables de algunas de las enfermedades que afectan a las poblaciones más empobrecidas e indefensas del planeta, lo que no supone, en términos generales, un desafío prioritario para las grandes empresas farmacéuticas. La tripanosomiasis humana africana, la enfermedad de Chagas y las distintas formas de leishmaniosis, se encuentran en la lista de la Organización Mundial de la Salud (OMS) de las denominadas "Enfermedades Tropicales Desatendidas" (ETDs). Estas enfermedades reducen de manera permanente el potencial humano, manteniendo a más de mil millones de personas sumidas en la pobreza, y suponen, por tanto, una enorme carga económica para los países endémicos. Aunque la patogénesis de estas enfermedades se debe principalmente a una desregulación del sistema inmune del hospedador, en la actualidad no existen vacunas efectivas en el mercado $\mathrm{y}$, además, los tratamientos farmacológicos presentan una toxicidad elevada, un alto coste $\mathrm{y}$, en muchos casos, requieren de una administración intravenosa, por lo que la adherencia al mismo se ve reducida significativamente. Por todo ello, las estrategias de control están basadas en la prevención y en el uso de la quimioterapia.

Sin embargo, algunas iniciativas como el DNDi (Drugs for Neglected Diseases initiative), una organización sin ánimo de lucro fundada por la ONG Médicos sin Fronteras (MSF), y otras instituciones públicas, además de la fundación Tres Cantos Open Lab, respaldada por la empresa farmacéutica GlaxoSmithKline - la cual posee miles de compuestos procedentes de distintas librerías a disposición de los investidagores -, son algunas de las iniciativas internacionales creadas con el único objetivo de erradicar las ETDs durante esta década. Por todo ello, existe una necesidad urgente de desarrollar sistemas de alto rendimiento (High Throughput Screening, HTS) fiables y eficientes que permitan cribar cantidades ingentes de compuestos potenciales contra estas enfermedades infecciosas.

Los estudios que emplean patógenos modificados genéticamente que expresan proteínas fluorescentes o bioluminiscentes han experimentado un crecimiento exponencial durante los últimos años (Reguera y col., 2014). Esta metodología supone un añadido de vital importancia para los "screenings" HTS (Freitas-Junior y col., 2012), y para los estudios in vivo a tiempo real de la patogénesis y las terapias potenciales contra las enfermedades parasitarias (Saeij y col., 2005; Franke-Fayard B. y col., 2006). Otra aplicación reciente de las cepas fluorescentes en combinación con análisis genómicos, es el descubrimiento de procesos de intercambio genético en tripanosomátidos, al igual que la aparición de nuevas cepas en las poblaciones naturales (Miles y col., 2009).

El presente trabajo está centrado en los parásitos del género Leishmania, los cuales son organismos heteroxenos que presentan dos formas principales en su ciclo biológico: la forma extracelular o promastigote, móvil y flagelada, que se desarrolla en el interior del vector invertebrado; y la forma intracelular o amastigote, redondeada, aflagelada y, por tanto, inmóvil, diferenciada en el interior de los macrófagos del hospedador mamífero. Estos parásitos son los responsables de un 
amplio rango de enfermedades que afectan las membranas mucosas y la piel cepas cutáneas y mucocutáneas-, y los órganos internos -cepas viscerales-. Los tres estudios que se presentan tienen en común el empleo de parásitos de Leishmania spp. modificados genéticamente para conseguir la expresión estable de distintas proteínas fluorescentes. Esta metodología nos ha permitido llevar a cabo estudios HTS empleando un modelo ex vivo de esplenocitos murinos infectados y el seguimiento in vivo a tiempo real de una infección cutánea por L. major, además de demostrar por primera vez el intercambio genético intraclonal en L. infantum. Los reporteros fluorescentes deberían expresarse a lo largo de todo el ciclo biológico del parásito, por lo que, todos los marcadores fluorescentes fueron integrados en el ARN ribosomal (ARNr) 18S, lo que aseguró unos niveles de transcripción elevados y constitutivos en todas las fases del ciclo (Millington y col., 2010). Además, la integración de un gen exógeno supone una estrategia eficiente para garantizar una expresión estable en aquellos casos en los que la ausencia de antibióticos de selección sea requerida, como los estudios in vivo en animales. Cabe tener en cuenta que la modificación genética de los parásitos no debe alterar la patogenicidad y la virulencia de los mismos, ni crear resistencias.

El primer trabajo titulado "Gimatecan and other camptothecin derivatives poison Leishmania DNA-topoisomerase IB leading to a strong leishmanicidal effect", establece, tanto in vitro como ex vivo, la actividad leishmanicida de compuestos inhibidores de la ADN topoisomerasa IB de Leishmania (TopIB), mediante el empleo de una cepa fluorescente de L. infantum que sobreexpresa la proteína infrarroja IFP 1.4. La actividad de todos los compuestos fue analizada en promastigotes extracelulares y en un modelo ex vivo de esplenocitos murinos infectados con los amastigotes fluorescentes de dicha cepa, un modelo HTS que había sido previamente validado para el descubrimiento de nuevos fármacos (Osorio y col., 2011).

En el segundo trabajo, "Appraisal of a Leishmania major strain stably expressing mCherry fluorescent protein for both in vitro and in vivo studies of potential drugs and vaccine against cutaneous leishmaniasis", se establece un método alternativo más rápido y económico para la monitorización a tiempo real del inicio y la progresión de una infección cutánea en ratones BALB/c empleando una cepa fluorescente de L. major. Esta cepa transgénica fue modificada para que expresara la proteína roja fluorescente mCherry para la cuantificación in vivo de la carga parasitaria a través de la emission de fluorescencia, y para evaluar la efectividad de una vacuna experimental.

Por último, el artículo titulado "First evidence of intraclonal genetic exchange in trypanosomatids using two Leishmania infantum fluorescent transgenic clones", supone la primera demostración de la existencia de intercambio genético intraclonal entre dos cepas de L. infantum en el interior del vector flebotomino Phlebotomus perniciosus. En este estudio se generaron dos cepas fluorescentes de L. infantum BCN 150 que fueron empleadas como cepas parentales en los experimentos de co-infección en la mosca. Dichas cepas expresaban de forma estable las proteínas fluorescentes Citrina y mCherry, y los marcadores de resistencia antibiótica a hibromicina $\mathrm{B}$ y a blasticidina, respectivamente. Aunque el intercambio genético es un proceso poco frecuente, los cuatro marcadores se intercambiaron en el interior del vector invertebrado y dos clones híbridos fueron 
recuperados. También se analizó la viabilidad de la progenie híbrida durante todo el ciclo biológico, y se infectaron ratones BALB/c estableciéndose la virulencia de los clones híbridos tanto in vitro como in vivo, aunque con un fenotipo de virulencia reducida en comparación con las cepas parentales. El intercambio genético es un fenómeno de vital importancia ya que puede ser el responsable de la aparición de cepas con una virulencia alterada o resistentes a fármacos en las poblaciones naturales.

En conclusión, el empleo de estas cepas fluorescentes de Leishmania spp. supone un gran avance en el estudio de la biología y la patología de esta enfermedad infecciosa. Algunas de las ventajas que presenta el empleo de parásitos transgénicos son: i) llevar a cabo estudios in vivo de imagen a tiempo real, los cuales permiten el estudio in situ de los tejidos infectados de un animal; ii) desarrollar sistemas HTS para la evaluación de miles de fármacos potenciales contra las leishmaniosis, apareciendo como una alternativa más adecuada a los métodos clásicos; iii) igualmente, supone una herramienta extremadamente sensible para el estudio a tiempo real del desarrollo de una infección, especialmente en las etapas más tempranas del proceso; y iv) pueden ser empleados como marcadores fenotípicos complementarios para evaluar procesos de intercambio genético en Leishmania. Por último, cabe destacar que esta técnica presenta ventajas bioéticas importantes ya que reduce de forma significativa el empleo de animales de experimentación necesarios para obtener resultados estadísticamente significativos. 
Trypanosomatidae is a Family of unicellular protozoan parasites responsible for some of the costliest and challenging poverty-related diseases. Sleeping sickness, Chagas disease, as well as the different forms of leishmaniasis, are all included in the list of the so-called "Neglected Tropical Diseases" (NTDs). All these diseases disable, debilitate, and often kill, one in six people worldwide, including half a billion children in low and lower middle income countries. Although the pathogenesis of these diseases is mainly due to deregulation in the normal immune system balance of the host, there are no effective vaccines currently on the market and, moreover, current pharmacological treatments are toxic, expensive or require intravenous administration, which hinders patient treatment adherence. Because of this, control strategies are based on prevention and chemotherapy. Since NTDs mainly affect people living in economic poverty, big pharma industry usually shows little interest in developing novel treatments to eradicate them.

The Drugs for Neglected Diseases initiative (DNDi), a non-profit R\&D organization founded by the NGO Medecins Sans Frontiers (MSF) and other public research Institutions, as well as the Tres Cantos Open Lab Foundation supported by GlaxoSmithKline - that provide thousands of compounds from different drug libraries to be tested by academic researchers -, are two international initiatives created with the aim to defeat NTDs by the end of this decade. Consequently, there is an urgent need to develop novel and reliable High Throughput Screening (HTS) systems that permit myriads of molecules to be tested using robotic facilities.

Scientific literature regarding pathogens that express fluorescent or bioluminescent proteins has experienced exponential growth during the last decade (Reguera et al., 2014). This methodology has been proved to be a powerful "add-on" for rapid in-vitro HTS (Freitas-Junior et al., 2012). Furthermore, it represents a major stride forward in the real-time in vivo study of both pathogenesis and potential therapies against parasitic diseases (Saeij et al., 2005; Franke-Fayard et al., 2006). Finally, the use of such fluorescent strains in combination with deep genomic analysis has led to the discovery of genetic exchange in trypanosomatids as well as the emergence of novel strains (Miles et al., 2009).

The present work is mainly focused on Leishmania parasites. Leishmania spp. is a heteroxenous parasite, either as motile promastigote form developing in sand fly guts or as a non-motile intracellular amastigote form in the definitive host macrophages of the mammalian host, including the human being. They cause a large spectrum of diseases affecting the skin mucous membranes and viscera. The three manuscripts presented here involve the genetic modification of Leishmania parasites in order to stably express different fluorescent proteins into the parasite's genome. This approach allowed us to perform an ex vivo HTS platform and an in vivo appraisal of a cutaneous infection, both for drug screening purposes, and to demonstrate for the first time the intraclonal genetic exchange in $L$. infantum. Fluorescent reporters should be expressed during the complete parasite life cycle. To this end, all reporters were integrated into the 18S rRNA locus, under the control of rRNA promoter, which is known to present high-level transcription 
rates (Millington et al., 2010). Moreover, the integration of the reporter gene represents an efficient and effective strategy to guarantee a stable expression when the parasites need to be grown in the absence of selection drugs for both in vitro screenings and in mice infections. In addition, transgenic parasites should guarantee no modification of virulence or drug resistance levels when compared to those found in the wild-type counterpart.

The first manuscript entitled "Gimatecan and other camptothecin derivatives poison Leishmania DNA-topoisomerase IB leading to a strong leishmanicidal effect", assesses, both in vitro and ex vivo, the leishmanicidal activity of DNA topoisomerase IB (TopIB) inhibitors by using a fluorescent L. infantum strain which overexpresses the infrared protein IFP 1.4. The activity of the compounds was studied on extracellular promastigotes and on an ex vivo murine model of infected splenocytes with L. infantum fluorescent amastigotes, a validated HTS platform for drug discovery (Osorio et al., 2011).

By its part, the second work "Appraisal of a Leishmania major strain stably expressing mCherry fluorescent protein for both in vitro and in vivo studies of potential drugs and vaccine against cutaneous leishmaniasis", establishes an easier and cheaper tool of choice for real-time monitoring of the establishment and progression of a cutaneous infection in BALB/c mice by a fluorescent L. major strain. This transgenic strain was engineered to express the mCherry redfluorescent protein for in vivo follow-up of the parasitic load via measurement of fluorescence emission, and to assess the clinical progression of the infection after an experimental vaccine therapy.

Lastly, the article entitled "First evidence of intraclonal genetic exchange in trypanosomatids using two Leishmania infantum fluorescent transgenic clones", is the first report that addresses the intraclonal genetic exchange between two $L$. infantum fluorescent strains in its natural vector Phlebotomus perniciosus. This study involves two fluorescent $L$. infantum BCN 150 strains, engineered to express either the Citrine and mCherry fluorescent proteins and the hygromycin B and blasticidin $\mathrm{S}$ resistance cassettes, respectively. Although the genetic exchange is a rare process, all biomarkers were exchanged in the sand fly resulting in two hybrid clones. We also showed that the hybrid progeny were viable, can infect BALB/c mice and were virulent both in vitro and in vivo but with a lower virulence comparing to the parental strains. Genetic exchange appears as a phenomenon of extraordinary importance that can be responsible for the emergence of new virulent or drug resistance strains in natural populations.

In conclusion, the use of such fluorescent Leishmania strains represents a major stride forward in the study of the biology and pathology of this infectious disease. The use of these transgenic parasites introduces many advantages: i) in vivo imaging is useful when studying tissue harvested from infected animals since parasites can be individually identified; ii) it also permits to easily develop new platforms for the screening of potential new drugs by analysing libraries of thousands of compounds against leishmaniasis; therefore it may be an effective alternative to the tedious and time-consuming staining methods; iii) it is an extremely sensitive real-time tool to investigate the development of an infection, especially at the earlier phases of the infectious process; and iv) it can be used as a 
complementary phenotypic biomarker to evaluate the genetic-exchange occurrence in Leishmania. Last but not least, this technique is more ethical and humane as it significantly reduces the number of experimental animals to obtain similar statistical representativeness when compared to other approaches. 



\section{REVISIÓN BIBLIOGRÁFICA}




\section{REVISIÓN BIBLIOGRÁFICA}

\subsection{LAS ENFERMEDADES INFECCIOSAS: PASADO, PRESENTE Y FUTURO}

"Not a single year passes without [which]...we can tell the world: here is a new disease!" Rudolf Virchow, 1867

Ya en 1867 el médico alemán Rudolf Virchow, pionero en la definición moderna de patología, planteó la idea de la aparición de nuevas enfermedades debido simplemente al paso del tiempo (Virchow, 1879). A lo largo de nuestra "corta vida" en este planeta, los seres humanos hemos adquirido un número realmente elevado de patógenos. Una pequeña proporción de estos agentes son los causantes de las enfermedades humanas más importantes por lo que, inevitablemente, se encuentran entre los que más atención han atraído y siguen atrayendo. Nuestro conocimiento acerca de las enfermedades infecciosas no puede separarse del conocimiento intrínseco de la historia de la raza humana, ya que la distribución actual de muchas especies de patógenos a nivel mundial ha sido el resultado de las actividades humanas a lo largo de la historia, desde la salida de los primeros Homo sapiens de África y la colonización de nuevas tierras, hace ya más de 15.000 años (Templeton, 2002).

Algunos de estos agentes son parte de la herencia de nuestros antepasados primates, mientras que otros han sido adquiridos a través de distintas especies animales con las que hemos estado en contacto durante nuestra evolución, acuñándose el término zoonosis. Las enfermedades consideradas zoonóticas son aquéllas originadas por bacterias, virus, hongos o parásitos que pueden ser transmitidas de animales al ser humano. De igual modo, los asentamientos de población y el desarrollo de las primeras ciudades facilitaron la transmisión de infecciones, y la apertura de las rutas comerciales resultó en una rápida y amplia diseminación de estas enfermedades infecciosas. El comercio de esclavos, el cual se mantuvo activo durante más de tres siglos, promovió el traspase de especies patógenas nuevas desde el Viejo Mundo al Nuevo Mundo (Cox, 2002).

Nuestros ancestros, Homo sapiens sapiens, aparecieron en el este de África hace tres millones y medio de años, tras lo cual migraron a Europa, Asia y, por último, al continente americano, comenzando así el proceso de diferenciación (Nozais, 2003). El cambio en el estilo de vida nómada al sedentarismo tuvo lugar en Oriente Medio en torno al año 8.000 a.C. Las guerras y las migraciones, tanto espontáneas como forzadas (esclavitud), originaron importantes mezclas de población en Europa y África, lo que favoreció la diseminación de numerosas enfermedades parasitarias. Las tres especies causantes de malaria (Plasmodium falciparum, $P$. vivax y $P$. malariae) llegaron a la región mediterránea desde África con las primeras migraciones humanas. Por otro lado, los animales han jugado un papel clave en la transmisión y el mantenimiento de distintas especies parasitarias. El perro ha actuado como reservorio de las especies causantes de la leishmaniosis visceral, Leishmania infantum y L. donovani, al haber sido domesticado para uso humano durante miles de años. Otras especies de leishmaniosis cutánea como son L. major o L. tropica, han permanecido en contacto con los seres humanos al actuar como reservorios en especies de roedores salvajes. 
En las últimas dos décadas la parasitología humana ha estado fuertemente influenciada por la aparición de inmunodeficiencias adquiridas o secundarias, las cuales hacen particularmente vulnerables a los individuos que las padecen a contraer infecciones oportunistas, entre ellas, distintos tipos de leishmaniosis, toxoplasmosis o criptosporidiosis (Ambroise-Thomas, 2001). Además, algunas parasitosis típicas de animales, desconocidas en humanos, han pasado a considerarse zoonóticas y, en algunos casos, antroponóticas.

A lo largo del siglo XX los esfuerzos por luchar contra las enfermedades infecciosas han sido cuantiosos. A pesar de esto, desde la década de 1980 han surgido epidemias cuyos signos clínicos no habían sido documentados previamente (Ampel, 1991). La aparición de enfermedades nuevas puede deberse a distintos motivos, entre los que se encuentran mutaciones en los agentes patógenos, la aparición de cepas más virulentas y/o resistentes, o la introducción del agente infeccioso en poblaciones altamente susceptibles; factores ambientales o de comportamiento, tanto en el patógeno como en el hospedador, pueden influir en la aparición de una enfermedad olvidada o la modificación de una ya existente, comenzando así un nuevo ciclo de infección.

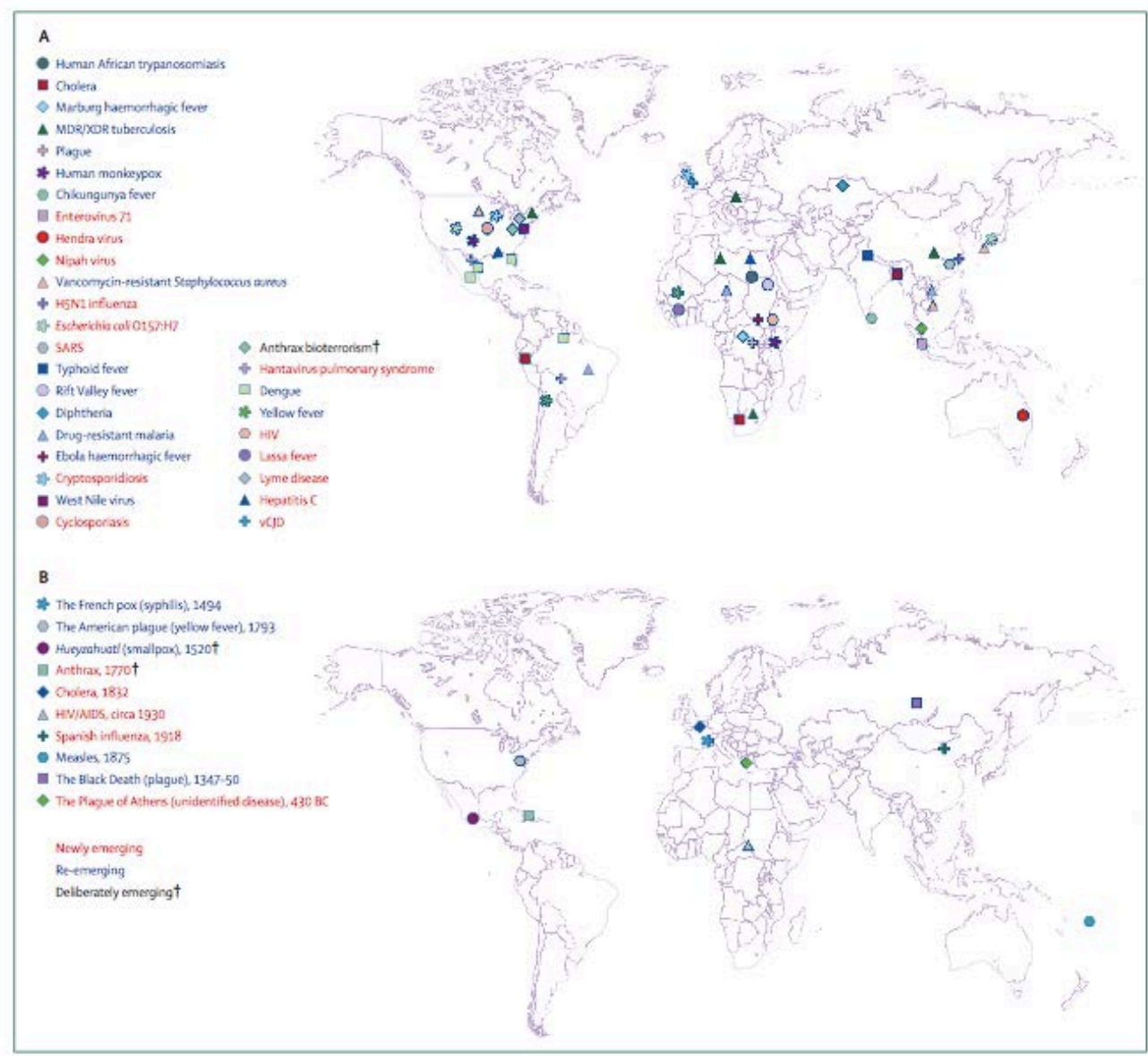

Figura 1.1. Distribución geográfica de enfermedades infecciosas "emergentes" (nuevas), "reemergentes" (ya conocidas) y "deliberadamente emergentes" (bioterrorismo) (Morens y col., 2008). 
En los últimos años podemos hablar de las leishmaniosis como enfermedades "reemergentes", debido a la frecuente aparición de epidemias en distintas zonas del planeta. Las regiones que se han visto afectadas en mayor medida por la leishmaniosis visceral (LV), la forma más seria de la enfermedad, incluyen Etiopía (2005-2006), Kenia (2008) y Sudán del Sur (2009-2012). Ésta última causó unos 28.300 casos y cerca de 900 muertes.

En la década de 1984 a 1994 tuvo lugar en Sudán una epidemia devastadora de LV. Al ser la primera en la zona, la población era altamente susceptible, estimándose unas 100.000 muertes como consecuencia de la enfermedad en una población de aproximadamente 300.000 personas. En algunos pueblos y aldeas, más de la mitad de los habitantes murieron de LV. Esta catástrofe provocó en 1997 una incidencia de nuevos casos de LV en Sudán del 400\% en comparación al año anterior, lo que causó una falta de abastecimiento de los tratamientos y el agotamiento de los stocks de los medicamentos de primera línea.

También han tenido lugar epidemias de leishmaniosis cutánea (LC) antroponótica recientemente. Uno de los lugares más afectados es Afganistán, donde las continuas guerras han creado un ambiente realmente propicio para la extensión de la enfermedad. En 2002 se reportaron 100.000 casos en Kabul, pero no es la única región en riesgo, también merecen especial atención zonas como de Pakistán (2004), Irán (2003), Siria, Alepo o Sudán.

Entre ellas se encuentran varias enfermedades infecciosas clásicas, como lo son las rabias o las originadas por las bacterias del género Rickettsia, o algunas enfermedades "nuevas" como las causadas por el virus del SIDA, la enfermedad de Lyme o el Síndrome Respiratorio Agudo Severo (SARS), causado por un tipo de coronavirus (Weiss, 2008). Los patógenos responsables de algunas zoonosis tales como las criptosporidiosis, toxoplasmosis o leishmaniosis han adquirido seria importancia debido a su capacidad para atacar a pacientes inmunodeprimidos afectados con el virus del SIDA. La mayoría de las enfermedades parasitarias clásicas debidas a helmintos, trematodos, cestodos o protozoos son zoonóticas (Krauss y James, 2003). Factores como la sobrepoblación, las migraciones, las actuaciones militares o la falta de abastecimiento de agua potable y de comida en buen estado en aún demasiados lugares del planeta, son los responsables de la alta incidencia de enfermedades zoonóticas en los últimos años.

De igual modo, avances médicos tales como los xenotransplantes o el uso de células animales en la producción de agentes terapéuticos pueden ser los responsables de la aparición de nuevas infecciones zoonóticas. Tanto el trasplante de órganos como las transfusiones de sangre han estado asociadas a la transmisión de distintos tipos de enfermedades infecciosas como lo son la leishmaniosis o la enfermedad de Chagas, debido a la presencia de estos parásitos en los donantes.

\subsubsection{Infecciones parasitarias: los primeros escritos}

Los parásitos (del latín parasītus, y este del griego $\pi \alpha \rho \alpha ́$ oı $\tau o \varsigma$, comensal) son organismos que viven a costa de otro, el hospedador, del que obtienen un hábitat y los nutrientes adecuados para sobrevivir. Los primeros escritos en los que se hace referencia a infecciones parasitarias datan del periodo comprendido entre los años 3.000 al 400 anterior a nuestra era en el antiguo Egipto. Tiene gran importancia el 
Papiro Ebers, uno de los tratados médicos más antiguos conocidos, descubierto en 1862 entre los restos de una momia en Luxor, estando fechado en torno al año 1500 a.C. (Bryan, 1974). Más tarde aparecen distintas descripciones detalladas de enfermedades que pueden ser o no causadas por parásitos, en concreto, diversas fiebres en escritos griegos (800-300 a.C.) como los recogidos en los trabajos de Hipócrates y también los encontrados en otras civilizaciones como en China (3.000-300 a.C.), India (2.500-200 a.C.), Roma (700-400 a.C.) o el imperio árabe musulmán en la última parte del primer milenio. Con el paso del tiempo, las descripciones de las infecciones comenzaron a ser más concretas y exactas, destacando los escritos de médicos árabes como Rhazes (850-923 d.C.) o Avicena (980-1037 d.C.), en los que claramente se describían enfermedades causadas por parásitos.

En Europa, la Edad Media se caracterizó por la existencia de fuertes creencias religiosas y supersticiones, lo que dejó los avances médicos relegados a un segundo plano; no fue hasta el Renacimiento cuando tuvieron lugar algunos descubrimientos de vital importancia los cuales marcaron el final del siglo XIX y comienzos del siglo XX. Algunos incluían la demolición de la teoría de la generación espontánea por Louis Pasteur, con la demostración de que las enfermedades podían ser causadas por microorganismos como las bacterias, el descubrimiento de los virus por Pierre-Paul Emile Roux, la prevención de las enfermedades causadas por microorganismos descrita por Robert Koch o la incriminación de los vectores en la transmisión de los parásitos llevada a cabo por Patrick Manson. Los inicios de la Microbiología y la Parasitología estaban comenzando a escribirse (Cox, 2002).

\subsubsection{Visión histórica de la leishmaniosis}

Las enfermedades conocidas como leishmaniosis están causadas por varias especies de protozoos parásitos del género Leishmania, transmitidas por la picadura de vectores flebotominos y diseminadas en el Viejo y el Nuevo Mundo. Los parásitos son organismos digenéticos con un ciclo vital complejo, los cuales penetran en el hospedador mamífero a través de la picadura del insecto vector e infectan y se multiplican dentro de células del sistema fagocitario, los macrófagos, los cuales son ingeridos de nuevo por el vector durante una nueva picadura, repitiéndose así el ciclo. La enfermedad presenta distintas formas clínicas pasando desde las ulceraciones típicas de la leishmaniosis cutánea (LC), la destrucción de tejidos cutáneos y subcutáneos por la leishmaniosis mucocutánea (LMC) o la afectación de órganos internos como bazo e hígado por las especies causantes de leishmaniosis visceral (LV).

Desde un punto de vista histórico es más fácil considerar las formas procedentes del Viejo Mundo como las primeras en aparecer en textos e ilustraciones antiguas. La LC en el Viejo Mundo es una enfermedad antigua conocida como "úlcera oriental", referenciada en tablillas de la famosa biblioteca del rey asirio Asurbanipal en torno al siglo VII a.C.; algunas de estas descripciones detalladas de los efectos de la enfermedad se creen que pueden proceder de textos anteriores datados de entre los años 1.500-2.500 a.C. (Manson-Bahr, 1933). Avicena y otros médicos árabes describieron las llamativas lesiones cutáneas en el siglo X d.C., las cuales recibieron el nombre de "úlcera de Balkh" en la zona del norte de Afganistán y otros lugares de Oriente Medio incluyendo Bagdad y Jericó; otras de 
las manifestaciones recibieron nombres locales por los cuales aún se siguen reconociendo. En el Nuevo Mundo aparecen lesiones cutáneas y deformaciones faciales principalmente en los labios superiores y en las fosas nasales de formas antropomorfas llamadas "huacos", encontradas en piezas de cerámica y artesanía halladas en los asentamientos de las culturas Mochica (1.330 a.C.- 500 d.C.) y Chimú (1.000-1.400 d.C.), en lo que hoy en día conocemos como Perú y Ecuador, manifestaciones típicas de la LC o LMC (Rabello E., 1925 12). Para obtener una descripción clínica de la enfermedad se tuvo que esperar hasta el siglo XVI, durante la Conquista Española del Nuevo Mundo. Fernando de Oviedo (1.535), Pedro Pizarro (1.571) y Fernando de Santillán (1.572) relataron cómo una "lepra blanca" azotaba a los indígenas en la ladera este de la Cordillera de los Andes, así como en los valles calientes y húmedos en los que se llevaba a cabo el cultivo de la coca. Esas úlceras, parecidas a las lesiones causadas típicamente por la lepra, recibieron el nombre de "lepra blanca", "enfermedad de los Andes" o "enfermedad del valle" (Lainson, 1983). En 1908 el médico peruano Edmundo Escomel indicó el gran parecido existente entre la fisionomía de las imágenes de huacos y la gente que padecía leishmaniosis cutánea (Escomel, 1929).

Ese mismo año aparece un alto número de personas aquejadas de padecer la enfermedad en la Santa Casa de São Paulo, recibiendo la enfermedad distintas denominaciones ("úlcera de Bauru", "lesión del noreste"), pero sin haberse identificado aún el agente etiológico. Sería el 30 de marzo de 1909 cuando Adolfo Lindenberg anunciara el descubrimiento del parásito causante de la leishmaniosis cutánea (Lindenberg, 1909). Originariamente se pensó que las leishmaniosis del Nuevo Mundo y la del Viejo Mundo eran las mismas, pero en 1911 Gaspar Vianna descubrió que los parásitos procedentes de América del Sur diferían de los encontrados en África o la India, apareciendo así una nueva especie, L. braziliensis (Vianna G., 1912). En ese mismo año, Pedroso y Dias da Silva, utilizando el medio Neal, Nory y Nicolle (NNN) obtuvieron cultivos de Leishmania procedentes de úlceras de Bauru (Pedroso y Silva, 1911). En 1922 y 1923 se realizaron las primeras infecciones experimentales con éxito empleando parásitos de $L$. braziliensis, inoculados en animales y, posteriormente, en humanos.

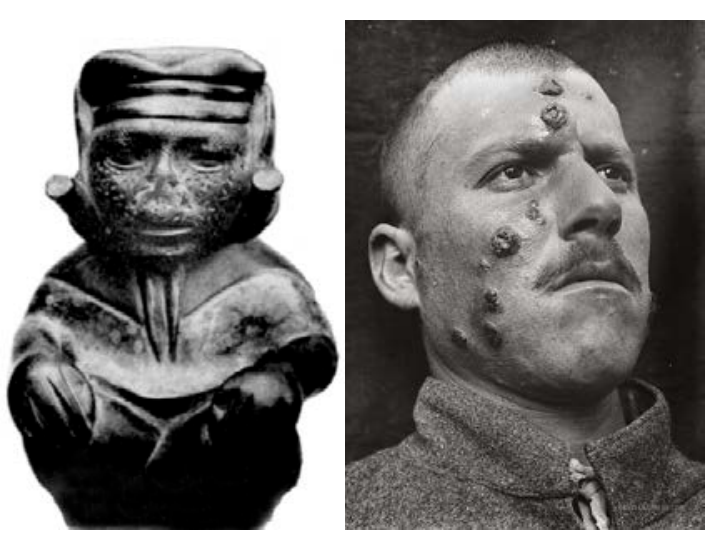

Figura 1.2. Huaco mochica exhibiendo la mutilación de la nariz y labio superior como consecuencia de infección cutánea. Soldado británico infectado con leishmaniosis cutánea en Oriente Medio, conocida como "botones de Jericó" (1917). 
La leishmaniosis visceral o "kala azar", se caracteriza por decoloraciones de la piel, fiebre y un agrandamiento del bazo o esplenomegalia, síntomas que llevaban a confusión con otras enfermedades, especialmente con la malaria. En 1756 el médico escocés Alexander Russell destinado en Alepo (Siria), hizo un avance importante en el descubrimiento de la leishmaniosis tras examinar a un paciente turco. Según sus propias palabras: "Después de que cicatriza, la herida deja una fea cicatriz que permanece de por vida, y durante varios meses presenta un color vivo. Si no se irrita apenas causa dolor alguno"; Russell llamó a esta enfermedad "botón de Alepo", la cual quedó recogida en su obra "La Historia Natural de Alepo" (Russell, 1756).

El kala azar o "fiebre negra" como también se la conocía, fue identificado por primera vez en la India en 1824 en pacientes que padecían de fiebres muy altas pero no respondían al tratamiento clásico de la malaria, la quinina. En 1862 la enfermedad se había extendido al noreste del país, a Bardhaman, alcanzando proporciones de epidemia (Gibson, 1983). Por aquel entonces la causa seguía siendo desconocida y varios de los médicos más eminentes como Ronald Ross, estaban convencidos de que el kala azar era una forma virulenta de malaria (Ross, 1899). No fue hasta 1900 cuando un médico militar escocés, William Leishman (Leishman, 1903 21), y un profesor de fisiología de la Universidad de Madrás en la India, Charles Donovan (Donovan, 1903), descubrieron al mismo tiempo y de forma independiente la verdadera naturaleza de la enfermedad al descubrir el agente responsable de la misma en bazos de pacientes infectados (Hoare, 1938). William Leishman sirviendo en la Armada Británica en la India, desarrolló una de las primeras tinciones de Leishmania en 1901.

En Dum Dum, una ciudad cercana a Calcuta, descubrió la presencia de cuerpos ovoides en el bazo de un soldado inglés que había muerto aquejado de súbitas fiebres, anemia, atrofia muscular y agrandamiento del bazo. Leishman describió la enfermedad como "fiebre dum dum" y consideró que se trataba de alguna especie de Trypanosoma. Por su parte, Charles Donovan también reconoció los mismos síntomas en otro paciente aquejado de kala azar y publicó sus hallazgos pocas semanas después que Leishman. Tras examinar el parásito empleando la tinción de Leishman, las formas intracelulares o amastigotes fueron conocidos como "corpúsculos de Leishman-Donovan", aunque sería el médico británico nacido en la India, Ronald Ross, quien propondría estas formas redondeadas y pequeñas como parte del ciclo de vida del nuevo parásito, siendo él quien dio el nombre de Leishmania donovani al agente responsable en honor a Leishman y Donovan (Ross, 1903). La enfermedad se convirtió en un problema importante para las tropas aliadas mientras luchaban en Sicilia en la Segunda Guerra Mundial y sería un protozoológo e investigador británico, Leonard Goodwin, quien buscaría un tratamiento para tratar a los soldados británicos infectados con leishmaniosis; se le atribuye el cálculo de la dosis de fármaco administrada a una persona para curar la infección o "índice quimioterapeútico", la introducción del hámster sirio como modelo animal de leishmaniosis visceral y el tratamiento efectivo con la droga Pentostam (Goodwin, 1995). 


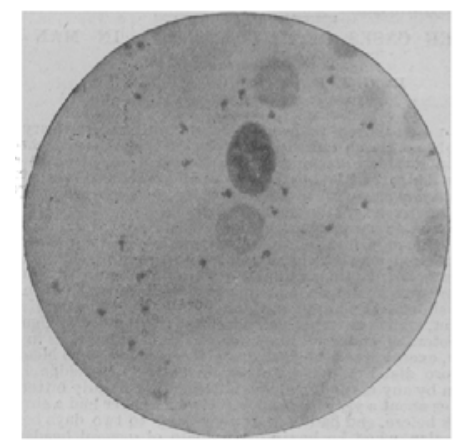

Figura 1.3. Preparación procedente de un bazo de un hombre aquejado de "dum dum", realizada 38 h después de la muerte del individuo mediante tinción de Romanowsky (Leishman, 1903). Se trata de la primera visualización de amastigotes, definidos por el mismo Leishman como "pequeños cuerpos circulares u ovalados".

El descubrimiento de los parásitos causantes de la LC en el Viejo Mundo sigue siendo controvertido ya que fueron varios los que describieron estructuras que podían atribuirse o no al parásito en cuestión. El descubrimiento del parásito se le atribuye al médico americano James Homer Wright (Wright, 1903), aunque no hay duda de que el médico escocés David Cunningham (Cunningham, 1885) ya lo había visualizado en 1885 pero sin ser capaz de relacionar el agente infeccioso con la enfermedad. En 1898 el cirujano militar ruso P.F. Borovsky realizó estudios sobre la etiología del kala azar en Tashkent (Uzbekistán), localmente conocida como "dolencia Sart", y en 1898 publicó en una revista rusa la primera descripción precisa del agente causal, relacionando exitosamente el parásito con los tejidos afectados de los pacientes (Hoare, 1938).

La búsqueda del vector fue más compleja. La idea de la participación de un vector como responsable de la propagación del parásito surgió de Presat en 1905, quien señaló como principales sospechosos a los mosquitos del género Phlebotomus; aunque no es hasta 1921 cuando existe una prueba experimental de la transmisión a humanos por estos flebotomos, demostrado por los hermanos Edouard y Etienne Sergent (Sergent y col., 1921). Nicolle y Comple descubrieron el papel de los animales salvajes y domésticos como reservorios de la infección en 1908 al encontrar un perro tunecino infectado por leishmaniosis visceral. Parte del ciclo biológico que afecta al modo en que el mosquito transmite los parásitos al hospedador a través de la picadura no fue demostrado hasta 1941 (Adler y Ber, 1941). Tras el descubrimiento del vector responsable de la transmisión del parásito en el Viejo Mundo se asumió erróneamente que en el Nuevo Mundo eran también los mosquitos del género Phlebotomus los que transmitían la enfermedad, aunque en 1922 se atribuyó este hecho a los mosquitos del género Lutzomyia.

\subsection{LAS ENFERMEDADES TROPICALES DESATENDIDAS (ETDS)}

Según la Organización Mundial de la Salud (OMS) en su último informe actualizado en enero de 2014, existen aproximadamente 1,3 millones de casos nuevos de leishmaniosis a nivel mundial, con unos datos de mortalidad estimados entre las 20.000-30.000 muertes anuales. La enfermedad afecta a las poblaciones más 
pobres del planeta, estando asociada con estados de desnutrición, desplazamientos de población, un sistema inmune debilitado, ausencia de una vivienda correctamente acondicionada, y falta de recursos en general. Otros cambios ambientales como son la deforestación, la construcción de presas, los sistemas de riego y los procesos de urbanización influyen en la distribución del vector y, por tanto, en la transmisión de la enfermedad. Igualmente el calentamiento global facilita la presencia de los vectores en zonas templadas en las que nunca antes habían sido detectadas (Desjeux, 2004). Sin embargo, desde 1993 lo que parecía una enfermedad de países pobres o en vías de desarrollo, se ha extendido a países del llamado "Primer Mundo" como Francia, Alemania, España, etc.

Las leishmaniosis se engloban entre las Enfermedades Tropicales Desatendidas (ETDs), las cuales son un grupo diverso de enfermedades causadas por distintos patógenos, entre ellos, bacterias, protozoos y helmintos, principalmente. El concepto "desatendidas" se refiere a que afectan casi exclusivamente a las poblaciones más pobres y marginadas del planeta y que han sido prácticamente erradicadas, y por lo tanto olvidadas, en las regiones más ricas para las que no constituyen una amenaza importante. Estas enfermedades incapacitan y matan a millones de personas, por lo que representan una urgencia sanitaria importante que sigue sin ser atendida, como demuestra la escasez de fondos destinados al desarrollo de nuevos fármacos. Aunque las enfermedades tropicales y la tuberculosis sean responsables del 11,4\% del cómputo global de enfermedades padecidas por la población mundial, sólo $21(1,3 \%)$ de los 1556 nuevos medicamentos registrados entre 1975 y 2004, fueron desarrollados específicamente para su tratamiento (Chirac y Torreele, 2006). Un estudio reciente sobre la financiación mundial en innovación para las ETDs, reveló que menos del $5 \%$ se invirtió en el grupo de enfermedades extremadamente olvidadas como la enfermedad del sueño, la leishmaniosis visceral y la enfermedad de Chagas, a pesar de que más de 500 millones de personas las padecen. Un dato esperanzador es que el acceso a la quimioterapia preventiva para al menos una de las enfermedades desatendidas en el año 2011 fue de 728 millones de personas.

Las 17 ETDs priorizadas por la OMS afectan a más de 1 billón de personas en todo el mundo y son endémicas en 149 países. El 7 de abril de este año 2014 se celebró el Día Mundial de la Salud cuyo tema principal fue las enfermedades transmitidas por vectores, entre las que se encuentran siete de las 17 ETDs, destacando la enfermedad de Chagas (causada por el protozoo flagelado Trypanosoma cruzi), la tripanosomiasis humana africana o "enfermedad del sueño" (causada por los tripanosomátidos T. brucei gambiense y T. b. rhodesiense) o las leishmaniosis. Se estima que hoy en día más de la mitad de la población mundial está en riesgo de contraer alguna de las enfermedades transmitidas por vectores.

Los intentos por controlar y erradicar las enfermedades tropicales comenzaron hace ya más de 10 años en la primera reunión organizada por la OMS que tuvo lugar en Berlín en el año 2003. Aunque las reuniones se mantuvieron durante dos años más, la estrategia elegida cambiaba la perspectiva anterior, ya que el Nuevo enfoque iba a ir en concordancia con las necesidades humanas y sanitarias y las comunidades más empobrecidas y marginadas. Desde entonces se han llevado a cabo y se siguen manteniendo cinco estrategias principales: 
* Quimioterapia preventiva: persigue una distribución a gran escala de medicinas gratuitas, de calidad y empleadas a concentración única, tanto solas como en combinación con otras.

* Administración innovadora e intensiva de las enfermedades: control a través de la gestión de casos de las enfermedades que son difíciles de diagnosticar y de tratar, y que en la mayoría de los casos provocan manifestaciones y complicaciones clínicas graves.

* Control de los vectores y manejo de los plaguicidas: busca una gestión segura y prudente de los plaguicidas en la salud pública para lograr el control del vector.

* Disponibilidad de agua potable, servicios de saneamiento y de higiene básica y educación: este ambicioso objetivo persigue la priorización de un saneamiento mejorado combinado con la administración de quimioterapia preventiva y la educación para la salud para sostener las reducciones en la prevalencia de muchas de estas enfermedades.

* Control de enfermedades zoonóticas: entre ellas, los distintos tipos de leishmaniosis; se busca la aplicación de las ciencias veterinarias e intervenciones para proteger y mejorar la salud humana (también conocida como la salud pública veterinaria).

La hoja de ruta dibujada hace ya una década dejaba entrever la necesidad de sistemas de prevención y control de la enfermedades tropicales desde un punto de vista integrado, priorizando en todo momento las necesidades de salud pública de las poblaciones más pobres del planeta, así como la existencia de mecanismos de actuación a un coste adecuado. En enero del año 2013, la OMS publicó su segundo informe sobre las Enfermedades Tropicales Desatendidas, en el cual se destacaban los enormes progresos conseguidos desde 2010 y que había permitido estar cercanos a desaparición de algunas de las 17 enfermedades infecciosas, como la erradicación total de la dracunculiasis en 2015 o la frambesia en 2020, o la eliminación de la lepra, la filariasis o la tripanosomiasis africana en 2020.

\subsection{LEISHMANIOSIS}

\subsubsection{Epidemiología de la enfermedad y principales factores de riesgo}

Las leishmaniosis son un grupo de enfermedades causadas por los protozoos parásitos del género Leishmania. Más de 20 especies de Leishmania son capaces de infectar a humanos transmitiéndose el parásito a través de la picadura de hembras de flebotomos. Existen tres formas principales de leishmaniosis: i) la forma visceral (LV), conocida comúnmente como kala-azar y la forma más seria y peligrosa de la enfermedad, mortal si no se trata; ii) leishmaniosis cutánea (LC), la forma más común; iii) la forma mucocutánea (LMC) y iv) una forma cutánea que aparece como secuela tras padecer LV, denominada leishmaniosis dérmica post kala-azar (LDPK). 
Como se apuntó en el apartado anterior, la enfermedad afecta principalmente a las poblaciones más empobrecidas del planeta, entre ellas, África, Asia y América del Sur, siendo endémica en más de 98 países. Se estima que aproximadamente cada año aparecen entre 0,2-0,4 millones de nuevos casos de LV y entre 0,7-1,2 millones de personas infectadas de novo de LC.
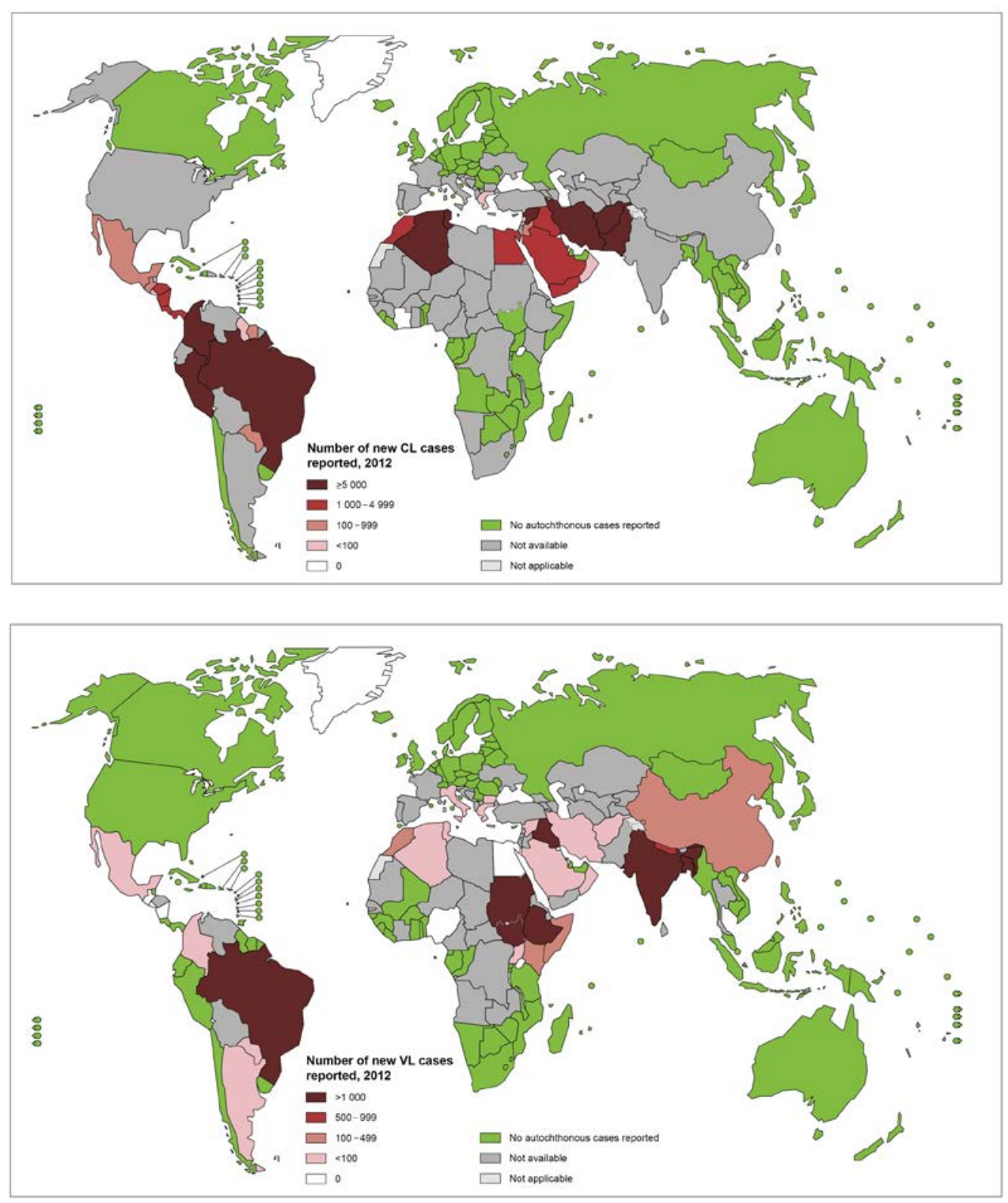

Figura 1.4. Distribución de los casos endémicos de leishmaniosis cutánea y visceral a nivel mundial (OMS, 2012).

La LV es altamente endémica en la India y el este de África y con estimaciones de unos 200.000-400.000 casos nuevos a nivel mundial cada año. Más del $90 \%$ de estos casos nuevos se encuentran distribuidos en seis países: Bangladesh, Brasil, Etiopía, India, Sudán del Sur y Sudán. La afectación cutánea posterior a la LV, LDPK, tiene lugar principalmente en el este de África y en la India, donde hasta el 50\% y 
el $5-10 \%$ de los pacientes con $\mathrm{LV}$, respectivamente, podrían desarrollar la enfermedad.

En cuanto a la LC, la población aquejada de padecer la enfermedad presenta una distribución más amplia; sin embargo, en torno a un tercio de los casos aparecen en tres regiones epidemiológicas diferenciadas: América, la cuenca del Mediterráneo y Asia occidental desde el Medio Oriente hasta Asia Central. La epidemiología de la LC en el continente americano es realmente compleja, existiendo variaciones intra e interespecíficas en los ciclos de transmisión, en los animales que actúan como reservorios, los vectores y diferentes manifestaciones clínicas y respuestas a los tratamientos causado, en parte, por la presencia de múltiples especies de Leishmania en la misma zona geográfica. Los diez países con mayor número de casos son Afganistán, Argelia, Brasil, Colombia, Costa Rica, Etiopía, Irán, Perú, Sudán y Siria, y en conjunto representan el 70 y el 75\% de la incidencia mundial estimada de CL. Por otra parte, casi el $90 \%$ de los casos de LMC tienen lugar en Bolivia, Brasil y Perú.

Sin embargo, los datos oficiales de que se dispone subestiman la realidad debido a varios factores limitantes: a) la distribución de las zonas de transmisión en áreas endémicas es frecuentemente discontinua, b) no son diagnosticados o no son declarados numerosos casos, c) la mayoría de los datos oficiales se obtienen exclusivamente a partir de la detección pasiva de los casos, d) el número de personas asintomáticas infectadas es mucho mayor que el de casos clínicos manifiestos (Riera y col., 2008).

* Como se comentó anteriormente, algunos de los principales factores de riesgo para contraer la enfermedad son:

* Factores socioeconómicos: La pobreza aumenta el riesgo de infección. Malas condiciones sanitarias como por ejemplo, la ausencia de gestión de residuos o de alcantarillado o el hacinamiento, se convierten en hábitats ideales para el desarrollo del flebotomo, así como su acceso al ser humano. Otros comportamientos humanos como dormir al aire libre o en el suelo, pueden aumentar el riesgo. El uso de mosquiteros tratados con insecticidas lo reduce.

* Desnutrición: Las dietas que poseen niveles bajos de proteínas, hierro, vitamina A y zinc aumentan el riesgo de que una infección progrese a kalaazar.

* Movimientos de población: Las epidemias de las dos principales formas de leishmaniosis están a menudo asociados con la migración y el desplazamiento de población susceptible a áreas con ciclos de transmisión existentes. La exposición ocupacional, así como la deforestación generalizada siguen siendo factores importantes. Por ejemplo, las personas que se establecen en zonas que antes eran bosques pueden estar moviéndose cerca del hábitat natural de los flebotomos. Esto puede conducir a un rápido aumento de los casos.

* Cambios ambientales: Los cambios ambientales que pueden afectar la incidencia de leishmaniosis incluyen la urbanización, la domesticación del 
ciclo de transmisión y la incursión de las explotaciones agrícolas y asentamientos en las zonas boscosas.

* Cambio climático: La leishmaniosis es extremadamente sensible al clima. El calentamiento global y la degradación de la tierra influyen conjuntamente en la epidemiología de la enfermedad; los cambios en la temperatura, las precipitaciones y la humedad pueden tener un gran efecto en vectores y reservorios, modificando su distribución ya que influyen en su supervivencia y el tamaño de las poblaciones. De esta manera, pequeñas fluctuaciones en la temperatura puede tener un profundo efecto en el ciclo de desarrollo de los promastigotes en los flebotomos, lo que permitiría la transmisión del parásito en zonas que antes no eran endémicas para la enfermedad.

\subsubsection{Diagnóstico, prevención y tratamiento de la leishmaniosis}

El diagnóstico de la LV se realiza mediante la combinación de signos clínicos en los análisis parasitológicos o serológicos llevados a cabo (pruebas de diagnóstico rápido y otros). Las pruebas serológicas para identificar las leishmaniosis cutánea y mucocutánea tienen una validez muy limitada. Si bien es cierto que las manifestaciones clínicas en los análisis parasitológicos confirma el diagnóstico de padecer LC. El tratamiento de la leishmaniosis depende de varios factores, incluyendo el tipo de enfermedad, especie de parásito involucrada y la ubicación geográfica. La leishmaniosis es una enfermedad tratable y curable. Todos los pacientes con diagnóstico de leishmaniosis visceral requieren un tratamiento inmediato y completo.

La prevención y el control de la leishmaniosis requiere una combinación de estrategias de intervención debido a que la transmisión involucra un sistema biológico complejo que incluye el hospedador definitivo, el parásito, el vector invertebrado y, en algunos casos, el animal que actúa como reservorio. Alguna de las principales estrategias incluyen:

* Diagnóstico temprano y efectivo de la enfermedad: Reduce la prevalencia de la enfermedad y previene posibles discapacidades o minusvalías y, en los peores casos, la muerte. Actualmente existen medicamentos efectivos y seguros contra la LV y el acceso a los mismos está mejorando en los últimos años.

* Control del vector invertebrado: Ayuda a reducir o interrumpir la transmisión de la enfermedad. Algunos de los métodos de control incluyen el empleo de insecticidas, mosquiteros rociados con insecticidas, la gestión ambiental y la propia protección personal. No sólo son necesarias las fumigaciones periódicas de las áreas endémicas sino también el conocimiento de la biología y naturaleza de los flebotomos, ya que estos insectos adquieren resistencias que perjudican el control de la enfermedad e indirectamente afectan a la sostenibilidad medioambiental.

* Control de reservorios: En las formas zoonóticas americanas la posibilidad de actuar contra los reservorios es prácticamente nula dado su carácter selvático. En las leishmaniosis con reservorios domésticos (como es el caso 
de nuestro país) o peridomésticos, se aconseja el control de los animales en los focos zoonóticos, mediante exámenes serológicos de los perros sospechosos y su tratamiento en el caso de que no se acepte su eliminación.

* Movilización social y educación de la comunidad: Fomento de la sensibilización sobre la morbilidad de la enfermedad y un acceso equitativo a los servicios de salud para su prevención y tratamiento, sin olvidar el impulso de las investigaciones relacionadas con el control de la leishmaniosis y la difusión de sus resultados.

El acceso a los medicamentos para el tratamiento de la leishmaniosis sigue siendo un problema de vital importancia en los países más pobres donde existe el mayor número de afectados por la enfermedad, a pesar de los esfuerzos realizados por la OMS, organizaciones no gubernamentales (ONGs) y empresas privadas. La problemática viene originada por los siguientes factores:

* Los tratamientos siguen siendo relativamente caros para estas poblaciones.

* Muchos de ellos siguen sin estar incluidos en las listas nacionales de fármacos esenciales en estos países.

* El suministro de medicinas no es siempre continuo al no existir una planificación de las necesidades mundiales de los medicamentos, lo que se traduce en escasez de fármacos, problemas con la calidad de los lotes y baja capacidad de producción al estar controlada la mayor parte del mercado por una única empresa farmacéutica.

En la 63aㅡ Asamblea Mundial de la Salud del 25 de marzo de 2010, la campaña de promoción de la OMS referente al acceso equitativo a los servicios de salud, en particular al acceso a los medicamentos, anunció dos grandes logros: el abaratamiento de dos de los cinco medicamentos existentes (un $90 \%$ la anfotericina B liposómica y un 60\% el antimoniato de meglumina) y la inclusión de dos nuevos medicamentos en la Lista Modelo OMS de Medicamentos Esenciales, la paromomicina en 2007 y la anfotericina B liposómica en 2008.

En diciembre de 2011, la OMS firmó un acuerdo con Gilead Sciences para la donación de inyecciones de anfotericina B liposómica para el tratamiento de distintos casos de LV en los países endémicos con peores expectativas durante el periodo 2012-2017.

\subsubsection{Situación de la leishmaniosis en España}

La leishmaniosis es una enfermedad considerada hipoendémica en nuestro país, con una prevalencia de 0,41 casos cada 100.000 habitantes. El agente causal de la misma es L. infantum, los vectores invertebrados principales son Phlebotomus perniciosus y P. ariasi y el perro aparece como reservorio principal. Entre febrero de 1982, cuando la enfermedad fue considerada de declaración obligatoria, y diciembre de 1995, fueron notificados 1.574 casos de leishmaniosis sin diferenciar entre casos de LC y LV (Alvar, 2001). Sin embargo, es manifiesta la subdeclaración de esta infección, entre el $25-40 \%$ de los casos de LV y de casi un $100 \%$ de los casos de LC, por lo que la incidencia real es desconocida y se calcula que como 
mínimo es dos veces superior si tenemos en cuenta los casos no declarados (Schönian y col., 2008).

Sin embargo, desde julio de 1996 y gracias a un sistema mejorado de vigilancia en las distintas Comunidades Autónomas, la enfermedad dejó de considerarse de obligada notificación en todo el país. Durante el periodo comprendido entre 19972008, se concluyó que un tercio de los casos estaban coinfectados con el Virus de la Inmunodeficiencia Adquirida (VIH), siendo las zonas de la Comunidad de Madrid y la costa mediterránea las regiones con una incidencia más elevada de personas infectadas. Durante esos 12 años de estudio la tasa de mortalidad fue del 3,31\% y el coste económico supuso unos 13 millones de euros (6.740 euros por paciente) (Gil-Prieto y col., 2011).

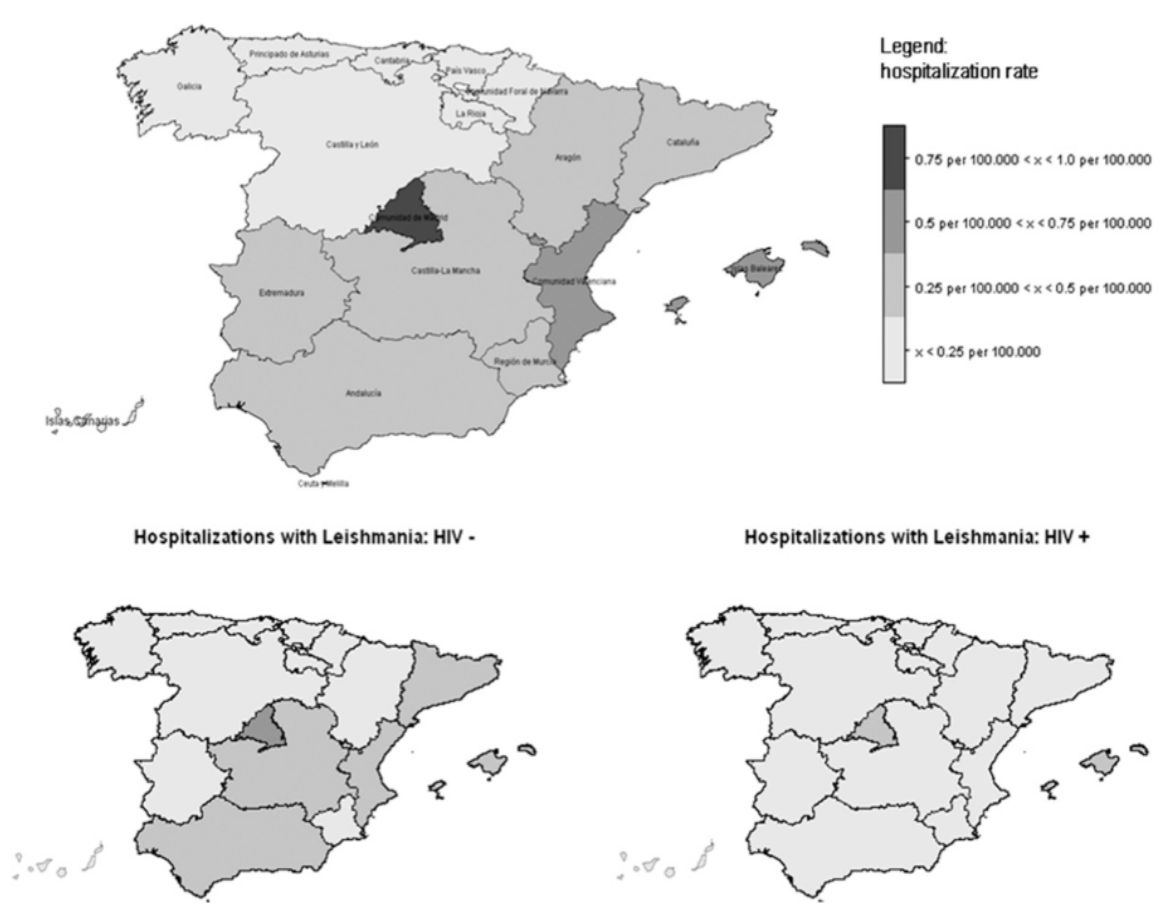

Figura 1.5. Incidencia de hospitalización por casos de leishmaniosis asociada o no al virus VIH en el periodo comprendido entre los años 1997-2008 (Gil-Prieto y col., 2011).

La mayoría de los casos de co-infección ocurrió en hombres adultos, con una edad comprendida entre los 25-35 años, siendo el 74\% drogodependientes (Alvar y col., 1997; López-Vélez y col., 1998). La leishmaniosis en pacientes inmunocomprometidos se debe a la reactivación de las infecciones subclínicas, pero también puede transmitirse mediante el uso de jeringuillas infectadas por vía intravenosa (Cruz y col., 2002). El número de personas coinfectadas alcanzó un pico en 1994 y disminuyó significativamente a menos de 10 casos en el año 2008 debido a la introducción de la Terapia Antiretroviral de Gran Actividad o TARGA (López-Vélez y col., 2001; Alvar y col., 2008). 


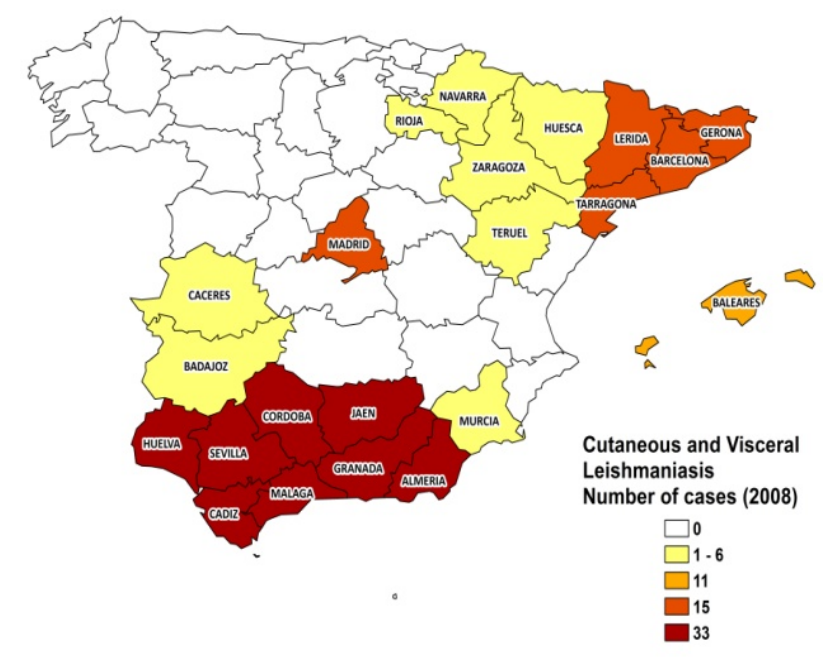

Figura 1.6. Distribución geográfica de los casos de leishmaniosis cutánea y visceral en España en el año 2008.

En la Comunidad de Madrid los casos de leishmaniosis humana cutánea y visceral comenzaron a aumentar durante los años 2010-2011 notificándose 204 casos, 100 casos de LC y 104 de LV. Recientemente, ha surgido un brote de leishmaniosis en Fuenlabrada (Madrid), aumentando su prevalencia rápidamente de 3 casos/100.000 habitantes en 2010 a 55,7/100.000 habitantes en 2011. Lo interesante de este brote es que, tal y como ha sido demostrado, liebres (Lepus granatensis) aparentemente sanas pero infectadas con L. infantum sirvieron como reservorio silvestre del parásito previo paso al mosquito vector $P$. perniciosus (Molina y col., 2012). Por su parte, la LV canina es endémica y su prevalencia varía entre el 4-35\% de perros seropositivos, con un 7,8\% de perros seropositivos en la Comunidad de Madrid y una alta proporción de éstos apareciendo como asintomáticos (Miró y col., 2007).

\subsection{EL GÉNERO LEISHMANIA}

El género Leishmania se clasifica dentro del orden Kinetoplastida, familia Trypanosomatidae, cuya característica representativa es la presencia de un orgánulo positivo a la tinción de Feulgen denominado kinetoplasto. Todas las especies de Leishmania son protozoos parásitos digenéticos que se caracterizan por: i) poseen un único flagelo que presenta una invaginación, la bolsa flagelar, ii) el kinetoplasto se localiza en el interior de una única mitocondria y iii) poseen una red de microtúbulos subpelicular que conforma la mayor parte del citoesqueleto (Ashford, 2000).

Son parásitos heteroxenos que requieren de la presencia de dos hospedadores para completar su ciclo biológico: un vector invertebrado, una hembra de díptero de los géneros Phlebotomus (en el Viejo Mundo) o Luztomyia (en el Nuevo Mundo); y un hospedador vertebrado definitivo (ya sea el perro, algún mamífero salvaje o el hombre). El parásito presenta diferencias morfológicas y bioquímicas según se encuentre en uno $u$ otro hospedador. La forma residente en el insecto se denomina 
promastigote y es un parásito móvil, fusiforme, muy parecido a un hemoflagelado; por su parte, el amastigote es una forma intracelular redondeada y carente de flagelo que reside en el interior de células del sistema monocítico-fagocitario del hospedador definitivo.

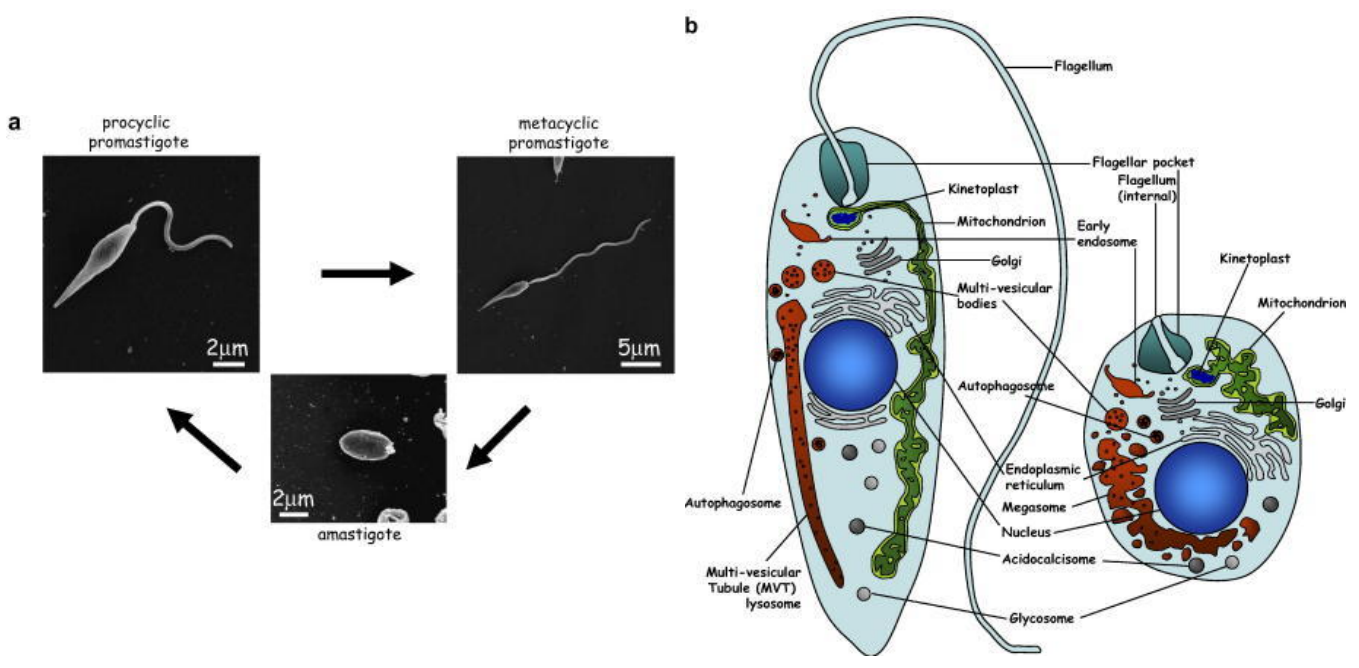

Figura 1.7. Cambios morfológicos durante el ciclo de los parásitos del género Leishmania. A. Imágenes de microscopía electrónica de los tres estadios más importantes del ciclo biológico del parásito: promastigote procíclico, promastigote metacíclico y amastigote. B. Representación esquemática de los principales orgánulos intracelulares de un promastigote (izquierda) y de un amastigote (derecha) (Besteiro y col., 2007).

La superficie de los promastigotes de Leishmania está recubierta por un glicocálix formado por moléculas importantes para la supervivencia del parásito y la patogénesis. De entre ellas destaca el lipofosfoglicano (LPG), el proteofosfoglicano (PPG), la metaloproteinasa gp63 y lípidos del ácido glicofosfatidilinositol (GIPLs). Una característica que diferencia la superficie de los parásitos de las células del huésped es la unión de muchas moléculas a anclajes de glicosilfosfatidilinositol (McConville y Ferguson, 1993; McConville y col., 2002). Leishmania también secreta moléculas de fosfoglicano como el proteofosfoglicano (sPPG) y la fosfatasa ácida (sAP) (Sacks y Kamhawi, 2001).

El LPG constituye el glicoconjugado más abundante de la superficie de los promastigotes de Leishmania. Está unido a la membrana del parásito mediante anclaje a una molécula de glicosilfosfatidilinositol seguido de un núcleo de heptasacárido al que a su vez se une un polímero compuesto de 15-30 unidades repetidas de galactosa y manosa [6-Gal $(\beta 1,4) \operatorname{Man}(\alpha 1)-P 04-]$, y un oligosacárido terminal (Descoteaux y Turco, 1999). La composición de los azúcares de las unidades repetidas varía en función de la especie y de la fase de desarrollo del parásito. 


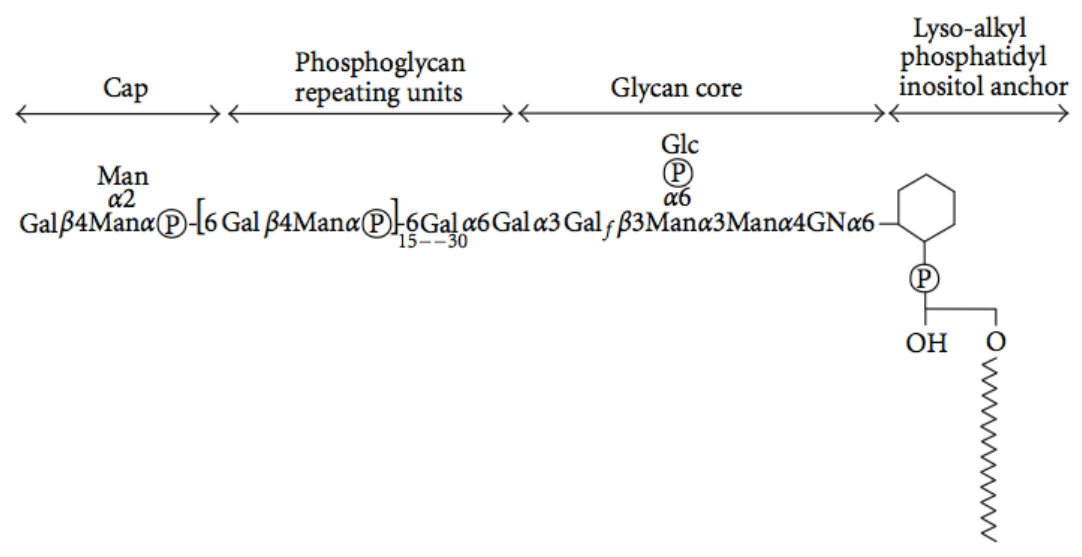

Figura 1.8. Estructura del LPG de la superficie de L. donovani formado por el anclaje de fosfatidilinositol, el núcleo de heptasacárido, las repeticiones de Gal y Man y la caperuza terminal (Franco y col., 2012).

Los promastigotes procíclicos y metacíclicos de Leishmania expresan grandes cantidades de LPG en su superficie, en contraste con la expresión atenuada en amastigotes de LPG y la expresión aumentada de PPG en el interior de los macrófagos (Turco y Sacks, 1991). En promastigotes el LPG juega un papel crucial para la supervivencia del parásito en el interior del vector invertebrado $\mathrm{y}$, de igual modo, en la interacción con los macrófagos del vector mamífero definitivo.

Los genomas completos de tres de las especies principales de Leishmania (L. major, L. infantum y L. braziliensis) han sido secuenciados recientemente, mostrando la existencia de más de 8.300 genes codificadores de proteínas, de los cuales únicamente un 35\% tienen asignada una función concreta, así como de 900 genes de ARN. Casi el 40\% de los genes codificadores de proteínas se pueden clasificar dentro de 662 familias con entre 2 y 500 miembros. Los genes grandes suelen estar dispersos a lo largo de todo el genoma en formaciones en tándem en diferentes loci, mientras que la mayoría de familias de genes pequeños forman grupos de uno a tres genes (Myler y Fasel, 2008).

Las especies de Leishmania del Viejo Mundo poseen 36 cromosomas, mientras que las del Nuevo Mundo tienen 34 o 35. Leishmania spp. presenta una organización genómica única dentro de los organismos eucariotas: sus genes no poseen intrones, y además, aunque el tamaño de los cromosomas es menor que el de otros organismos, presentan un mayor número de genes altamente empaquetados. Dichos genes se pueden organizar en una o en ambas hebras de ADN, formando transcritos policistrónicos a partir de promotores no definidos. El proceso de "trans-splicing" o transempalme está presente en el género Leishmania, y éste representa un paso necesario para el procesado de ARNm en los eucariotas inferiores mediante el empalme de exones de dos transcritos primarios distintos, con la consiguiente formación de un ARN híbrido (Kazemi, 2011).

Las distintas especies de Leishmania presentan las mismas características morfológicas cuando se emplean los métodos clásicos de diagnóstico, tales como la examinación microscópica o el cultivo de los parásitos. Por ello, históricamente estos parásitos se han clasificado en base a su distribución geográfica, la 
especificidad en cuando al vector invertebrado que los transmite, el tropismo tisular y las manifestaciones clínicas (Pratt y David, 1981). Recientemente, Fraga y colaboradores (2010) han propuesto una nueva nomenclatura para las diferentes especies de Leishmania empleando las secuencias de la proteína de choque térmico 70, Hsp70, altamente conservada. Según estos autores, dentro del complejo de $L$. donovani, únicamente L. donovani mantendría el nivel de especie y L. donovani infantum debería ser considera como una subespecie. De forma similar, solamente L. tropica y no L. aethiopica conservaría el nivel de especie, mientras que L. major se consideraría una especie independiente.

TABLA 1.1. Nueva propuesta de nomenclatura de Leishmania spp. basada en la secuencia del gen hsp70 (Antinori y col., 2012).

\begin{tabular}{|c|c|c|c|c|}
\hline Genus & Complex & Species & Geographic distribution & $\begin{array}{l}\text { Species according } \\
\text { to } h s p 70 \text { analysis }\end{array}$ \\
\hline \multirow[t]{10}{*}{ L. (Leishmania) } & \multirow[t]{4}{*}{ L. donovani } & L. donovani & $\begin{array}{l}\text { China, Indian subcontinent, Ethiopia, Sudan, Kenya, Iran, } \\
\text { Saudi Arabia, Yemen }\end{array}$ & \multirow[t]{4}{*}{ L. donovani } \\
\hline & & L. infantum & $\begin{array}{l}\text { Albania, Algeria, France, Greece, Italy, Morocco, } \\
\text { Portugal, Spain, Syria, Tunisia, Turkey, Yemen }\end{array}$ & \\
\hline & & L. chagasi & $\begin{array}{l}\text { Argentina, Bolivia, Brazil, Colombia, Ecuador, E1 Salvador, } \\
\text { Guadalupe, Guatemala, Honduras, Martinique, Mexico, } \\
\text { Nicaragua, Paraguay, Suriname, Venezuela }\end{array}$ & \\
\hline & & L. archibaldi & India, Sudan, Ethiopia, Lebanon, Israel & \\
\hline & \multirow[t]{3}{*}{ L. tropica } & L. tropica & $\begin{array}{l}\text { Afghanistan, Algeria, Azerbaijan, Greece, Iran, Iraq, } \\
\text { Israel, Morocco, Tunisia, Turkey, Yemen }\end{array}$ & \multirow[t]{2}{*}{ L. tropica } \\
\hline & & L. aethiopica & Ethiopia, Kenya & \\
\hline & & L. major & $\begin{array}{l}\text { Afghanistan, Algeria, Chad, Iran, Iraq, Israel, Libya, } \\
\text { Mauritania, Morocco, Syria, Sudan }\end{array}$ & L. major \\
\hline & \multirow[t]{3}{*}{ L. mexicana } & L. mexicana & $\begin{array}{l}\text { Belize, Colombia, Costa Rica, Dominican Republic, } \\
\text { Ecuador, Guatemala, Honduras, Mexico, Panama, Venezuela }\end{array}$ & \multirow[t]{3}{*}{ L. mexicana } \\
\hline & & L. amazonensis & $\begin{array}{l}\text { Bolivia, Brazil, Colombia, Costa Rica, Ecuador, French Guyana, } \\
\text { Panama, Peru, Venezuela }\end{array}$ & \\
\hline & & L. garnhami & Venezuela & \\
\hline \multirow[t]{6}{*}{ L. (Viannia) } & \multirow[t]{3}{*}{ L. guyanensis } & L. guyanensis & $\begin{array}{l}\text { Brazil, Colombia, Ecuador, French Guyana, Peru, Suriname, } \\
\text { Venezuela }\end{array}$ & \multirow[t]{2}{*}{ L. guyanensis } \\
\hline & & L. panamensis & $\begin{array}{l}\text { Belize, Colombia, Costa Rica, Ecuador, Honduras, Nicaragua, } \\
\text { Panama, Venezuela }\end{array}$ & \\
\hline & & L. naiffi & Brazil, French Guyana, Ecuador, Peru & L. naiffi \\
\hline & \multirow[t]{3}{*}{ L. braziliensis } & L. braziliensis & $\begin{array}{l}\text { Argentina, Belize, Bolivia, Brazil, Colombia, Costa Rica, } \\
\text { Ecuador, Guatemala, Honduras, Nicaragua }\end{array}$ & \multirow[t]{2}{*}{ L. braziliensis } \\
\hline & & L. peruviana & Peru & \\
\hline & & L. lainsoni & Brazil, Bolivia, Peru & L. lainsoni? \\
\hline
\end{tabular}

El origen y la evolución del género Leishmania sigue siendo hoy en día un tema que genera controversia y numerosas discrepancias. Se distinguen tres subgéneros: (L.) Leishmania, (L.) Viannia y (L.) Sauroleishmania, atendiendo al lugar en el que se desarrolla el parásito dentro del vector flebotomino. En el subgénero Leishmania se incluyen las especies del parásito que se desarrollan en el intestino medio del vector, como las especies del Viejo Mundo y el complejo mexicana del Nuevo Mundo, mientras que en el subgénero Viannia se agrupan las especies que se desarrollan en el intestino posterior, a la altura del triángulo pilórico, e incluye al resto de las especies del Nuevo Mundo (Lainson y Shaw, 1987). El subgénero (L.) Sauroleishmania incluye especies no patogénicas para los seres humanos cuyo hospedador definitivo son especies de reptiles, destacando entre ellas $L$. tarentolae; a pesar de haber sido excluido en varias ocasiones como subgénero, 
estudios filogenéticos basados en secuencias de ADN parecen haberlo situado claramente en su lugar (Orlando y col., 2002).

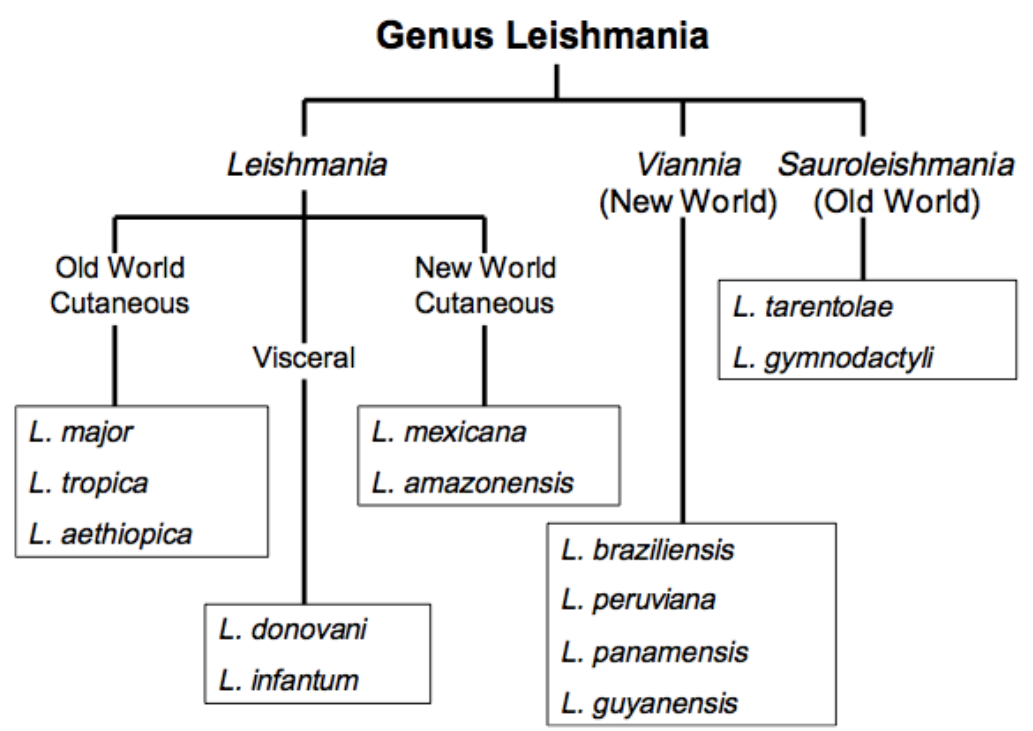

Figura 1.9. Clasificación de los subgéneros y las principales especies de los mismos en el campo de la investigación biomédica (Bates, 2007).

\subsubsection{Ciclo biológico de Leishmania spp.}

El ciclo infectivo de los parásitos obligados del género Leishmania comprende dos estadios morfológicos bien diferenciados: el promastigote flagelado y extracelular que prolifera en el vector invertebrado, y el amastigote intracelular aflagelado, el cual se multiplica en el interior de los macrófagos del hospedador mamífero definitivo ya sea el hombre, ciertos roedores salvajes o el perro.

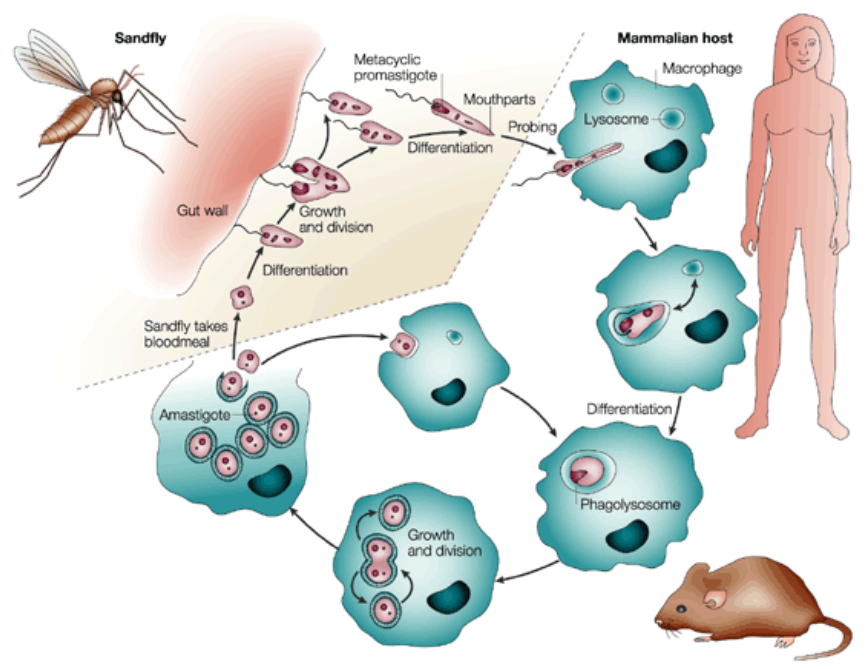

Figura 1.10. Ciclo biológico de Leishmania spp. (Sacks y Noben-Trauth, 2002). 
La etapa del ciclo que tiene lugar en el vector se inicia cuando los flebotomos ingieren sangre que contiene macrófagos infectados con amastigotes. Los flebotominos son una subfamilia de dípteros conocidos vulgarmente como moscas de las arenas (en inglés "sand flies'). Sólo las hembras son hematófagas, ya que la digestión de la sangre ingerida facilita la maduración de los oocitos y la oviposición (Klowden y Lea, 1978). Estos insectos se encuentran principalmente en regiones tropicales y subtropicales; además, son nocturnos, por lo que su momento de mayor actividad se registra al atardecer. No son activos a temperaturas inferiores a 16ㅇ $\mathrm{C}$ y en climas templados su actividad se desarrolla desde principios de verano a finales de otoño. De las más de 700 especies de flebotomos descritas, únicamente 70 son vectores probados o sospechosos de transmitir la leishmaniosis, y entre ellos las hembras de los géneros Phlebotomus y Lutzomyia son especies patogénicas para el ser humano (Killick-Kendrick, 1999).

La localización exacta de los parásitos en el interior del vector invertebrado varía entre los subgéneros (L.) Leishmania y (L.) Viannia. El subgénero del Nuevo Mundo (L.) Viannia accede a la parte posterior del intestino del insecto antes de alcanzar la parte media del mismo, lo que contrasta con las especies del subgénero (L.) Leishmania, cuyo desarrollo en el insecto queda restringido al intestino medio (Lainson y col., 1977). El paso de los parásitos desde el vector mamífero al insecto conlleva una serie de cambios como son el descenso de la temperatura y el aumento del pH, lo que origina distintas transformaciones morfológicas asociadas a cambios genéticos y bioquímicos (Charest y Matlashewski, 1994; Langford y col., 1994) necesarios para que los parásitos sobrevivan en el vector invertebrado.

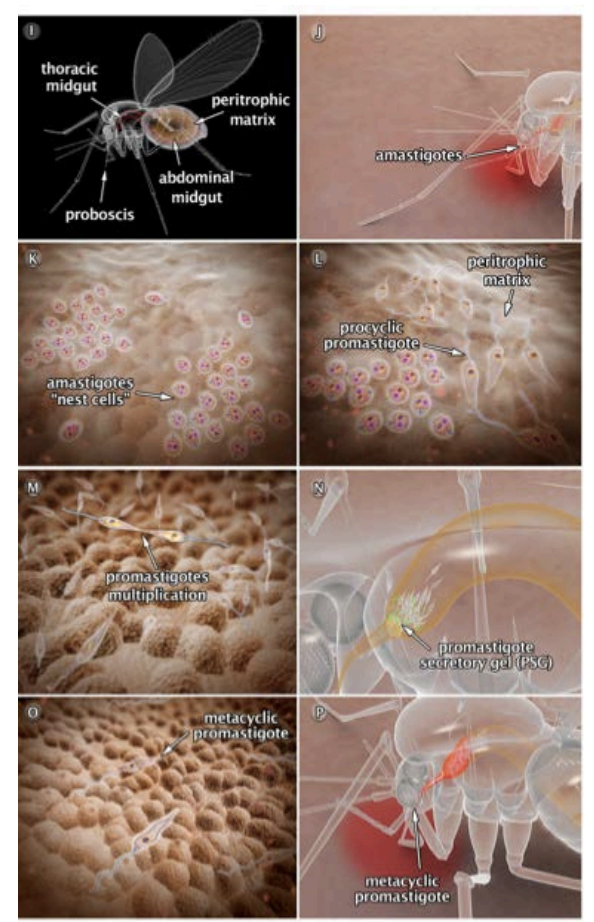

Figura 1.11. Representación de las fases de interacción entre los parásitos del género Leishmania y el vector invertebrado desde la succión de sangre que contiene macrófagos infectados con amastigotes hasta su transformación completa en promastigotes metacíclicos que serán transmitidos a un nuevo hospedador en la siguiente alimentación del insecto (Teixeira y col., 2013). 
La Figura 1.12 ejemplifica los distintos cambios morfológicos y los movimientos y migraciones de los parásitos en el interior del insecto. Los amastigotes se transforman en promastigotes procíclicos, poco móviles con un flagelo corto, siendo éstos las primeras formas replicativas que proliferan de manera más temprana tras la ingesta de sangre y que además se encuentran "atrapados" en el interior de la matriz peritrófica intestinal, secretada como barrera física por el epitelio intestinal. El intestino medio del vector flebotomino está compuesto por un epitelio de una sola capa recubierto por microvellosidades, las cuales rodean el lumen. Por su parte, el intestino anterior (incluyendo la válvula estomodeal), y el intestino posterior (que incluye el triángulo pilórico), están recubiertos de quitina. Tras 48-72 h, los parásitos comienzan a ralentizar su replicación y se diferencian enérgicamente a promastigotes nectomónadas, los cuales son muy alargados y altamente móviles (Rogers y col., 2002). Su acumulación en la parte anterior de la matriz provocará la ruptura de la misma por degradación enzimática; entonces las nectomónadas libres escaparán hacia la abertura posterior y se adherirán a las microvellosidades del intestino medio. Se moverán hacia la válvula estomodeal para diferenciarse a promastigotes leptomónadas, más cortos que los anteriores (Bates, 2007). La última diferenciación que tendrá lugar será la transformación de las formas leptomónadas en promastigotes metacíclicos infectivos o su adhesión a la capa de quitina de la válvula estomodeal como haptomónadas.

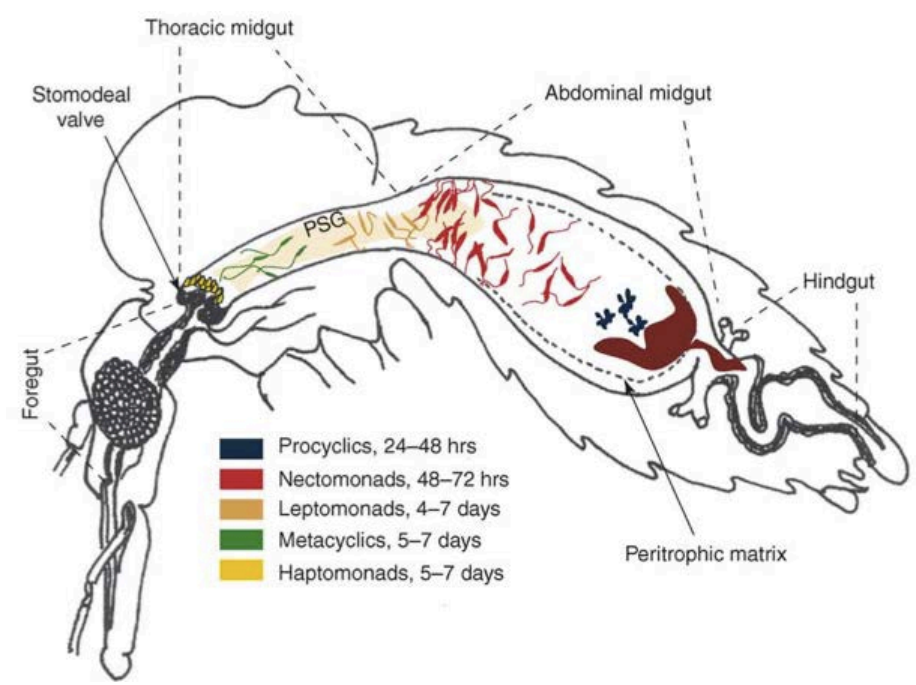

Figura 1.12. Desarrollo de los parásitos de Leishmania en el tracto digestivo del vector invertebrado (Kamhawi, 2006).

La transformación de los promastigotes no infectivos en parásitos altamente virulentos recibe el nombre de metaciclogénesis. Los promastigotes metacíclicos son más pequeños, delgados, con un flagelo más largo, dotados de gran movilidad y que migran hacia la parte anterior del tracto digestivo del insecto, ubicándose en la probóscide y por tanto listos para ser inoculados al hospedador en una nueva ingestión de sangre (Sacks y Perkins, 1984). In vitro la metaciclogénesis se induce al reducir el $\mathrm{pH}$ y restringir la cantidad de nutrientes disponibles, y entre ellos, 
parece ser que niveles bajos de tetrahidrobioterina actúan como señal para la diferenciación de los parásitos (Bates, 2008; Cunningham y col., 2001).

Este proceso de pre-adaptación del parásito para su transmisión al hospedador le confiere resistencia a la lisis por complemento (Handman, 1999) ya que, además de los cambios morfológicos, se sintetizan moléculas que se expresan exclusivamente en el promastigote infectivo (Moody, 1993; Coulson y Smith, 1990), destacando el LPG y la glicoproteína gp63 de la superficie de los promastigotes infectivos (ver apartado 1.4). Durante la metaciclogénesis, los principales cambios que tienen lugar en la molécula de LPG son un incremento de tamaño y la modificación en la composición de sus azúcares (Guha-Niyogi y col., 2001). Entre los papeles atribuidos al LPG se encuentra el de protección del parásito contra las enzimas proteolíticas del vector y la adhesión de los promastigotes al epitelio del intestino medio del insecto. Esta última propiedad parece exclusiva de los promastigotes procíclicos que posteriormente maduran hacia promastigotes metacíclicos infectivos y gracias a modificaciones en los azúcares terminales del LPG, se desprenden del epitelio y migran hacia la faringe y la cavidad bucal del díptero. En el hospedador definitivo el LPG posee importantes funciones; estudios realizados por Späth y colaboradores en 2003 empleando un mutante de L. major defectivo en LPG (L. major lpg1-), confirmaron los papeles determinantes de esta molécula en la virulencia del parásito, su resistencia al complemento, su capacidad para inhibir la fusión del fagolisosoma y la resistencia que confiere ante agentes oxidativos. Por otra parte, la proteína gp63 es una Zn-metaloproteasa (leishmaniolisina) de $63 \mathrm{kDa}$ que forma parte de la cubierta del parásito, proporcionándole resistencia a la lisis mediada por complemento y facilitando el reconocimiento de la zona de entrada al macrófago y la superviviencia del promastigote en el interior del fagolisosoma (Yao, 2010).

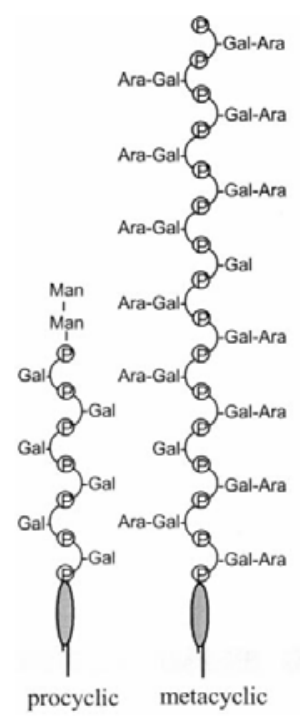

Figura 1.13. Representación de la molécula de LPG en promastigotes procíclicos y metacíclicos de L. major. El LPG se inserta en la membrana mediante unión a una molécula de fosfatidilinositol seguido de repeticiones de unidades de galactosa (Gal) y manosa-fosfato (Man) y una caperuza terminal de manosa. En los parásitos metacíclicos algunas modificaciones incluyen la duplicación de las unidades de fosfodisacárido y las cadenas laterales de galactosa (Gal) y arabinosa (Ara) (modificado de Späth y Beverley, 2001). 
Durante esta última fase en el interior del vector invertebrado, grandes cantidades de nectomónadas y de metacíclicos se acumulan en la zona anterior del intestino medio. Parece ser que las formas nectomónadas secretan proteofosfoglicano, creando un tapón de gel en el que se empaquetan los parásitos metacíclicos y que, además, obstruye el intestino a ese nivel (Rogers y col., 2004; Rogers y Bates, 2007). Las formas haptomónadas adheridas a la quitina de la válvula estomodeal contribuirán al colapso del intestino y dañarán la válvula por degradación enzimática al secretar quitinasas (Rogers y col., 2008). Por tanto, la transmisión de los parásitos sucede como consecuencia de la regurgitación de los mismos tras la obstrucción de la faringe del insecto por la alta densidad parasitaria, la secreción de moléculas de proteofosfoglicano que taponan el intestino medio torácico y la destrucción de la válvula estomodeal (Sacks y Perkins, 1985; Dostalova and Volf, 2012).

El grupo de Kimblin y colaboradores (2008), cuantificó el número de parásitos de L. major que eran transmitidos por el vector natural $P$. duboscqi; la mayor parte de las hembras depositaban una dosis infectiva baja ( $<600$ parásitos), mientras que el resto transmitía dosis más elevadas, lo que se correspondía con la presencia de altos porcentajes de parásitos presentes en el intestino medio antes de la succión de sangre. Mimetizando esta transmisión bimodal, inocularon una dosis elevada y otra baja en las orejas de ratones BALB/c mediante inyección intradérmica. Los animales que habían recibido el inóculo más alto desarrollaron lesiones mayores en un tiempo más reducido, mientras que los ratones inoculados con una menor carga parasitaria presentaron una patología menor pero con títulos parasitarios más elevados en la fase crónica de la enfermedad. En las especies viscerales el grupo de Maia y colaboradores (2011) observó cargas parasitarias más elevadas en una infección experimental con una cepa de L. infantum que tenía un tropismo dérmico en comparación con una cepa viscerotrópica de la misma especie.

Finalmente, el vector invertebrado introduce los promastigotes metacíclicos durante la succión de la sangre del mamífero. Estos parásitos metacíclicos estarán embebidos en la saliva infectiva del insecto, la cual contiene numerosos compuestos inmunomoduladores y bioactivos que facilitan el proceso de transmisión, destacando de entre ellos el maxadilano, el cual causa una marcada dilatación arterial (Moro y Lerner, 1997; Gillespie y Titus, 2000). Además, este proceso induce la secreción de las citoquinas antiinflamatorias IL-6, IL-1 $\beta$ e IL-10 (Wheat y col., 2008) y la activación de la cascada del complemento a través de las vías clásica o alternativa según la especie.En este momento el LPG y la proteína gp63 presentan un papel clave en el proceso de infección; las cadenas peptídicas de mayor longitud en las formas metacíclicas de este glicoconjugado son capaces de prevenir la unión de las proteínas C5b y C9 del complemento, mientras que la glicoproteína gp63 es capaz de convertir la proteína C3b en su forma inactiva C3bi, que se une a la superficie del protozoo evitando así el ataque de la proteína C5 del complemento (Sacks y col., 1995). Además, las proteínas C3b y C3bi favorecen la opsonización, atrayendo a los macrófagos hacia los promastigotes, que se unen a los receptores CR1 y CR3 de los macrófagos de los tejidos locales para ser fagocitados, formando una vacuola parasitófora y fusionándose con los lisosomas (Späth y col., 2003). 
Tras la picadura del mosquito, los parásitos tienen contacto con una gran variedad de tipos celulares: neutrófilos, células de Langerhans, células dendríticas, queratinocitos y macrófagos tisulares (Kaye y Scott, 2011). Los neutrófilos son rápidamente reclutados hacia el sitio de inoculación, siendo independiente este proceso de la presencia o no de parásitos, sino como consecuencia del daño tisular generado en la picadura. Peters y colaboradores (2008), demostraron cómo estos neutrófilos fagocitan de forma masiva los promastigotes metacíclicos, los cuales son liberados de neutrófilos apoptóticos, estando así disponibles para que los macrófagos los ingieran. Este estudio sugiere que el modelo del "caballo de Troya" (van Zandbergen y col., 2004) no refleja fielmente el principal mecanismo de la transferencia parasitaria in vivo, sino que favorece el modelo del "conejo de Troya", en el cual los parásitos escapan de los neutrófilos apoptóticos para infectar los macrófagos (Ritter y col., 2009). La fagocitosis de los parásitos metacíclicos por parte de los neutrófilos se produce por activación del complemento y por rutas dependientes e independientes de opsonina (Ofek y col., 1995; Uthaisangsook y col., 2002).

Las especies causantes de LC permanecen contenidas en el lugar de inyección multiplicándose en la piel o en zonas mucosas mientras que las formas viscerales se diseminan hacia los órganos internos diana, el hígado, el bazo y la médula ósea (Forestier, 2013). En el caso de las especies cutáneas, otras células importantes del sistema inmunitario durante el proceso de infección son las células dendríticas. Otro estudio demostró que tras la inyección de parásitos de L. major en la piel, las células dendríticas que son capaces de migrar a los nódulos linfáticos, responden específicamente ante la infección en las primeras horas, reduciendo su capacidad de migración y aumentando su actividad fagocítica contra los promastigotes de Leishmania para luego migrar a los ganglios linfáticos vecinos drenantes de la región afectada (Ng y col., 2008).

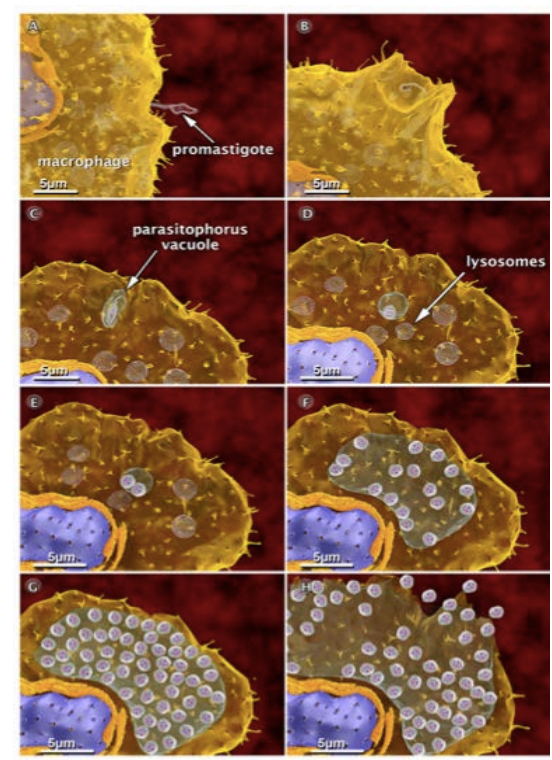

Figura 1.14. Representación de las fases de interacción entre los parásitos del género Leishmania en vector mamífero definitivo, tras la inoculación de los promastigotes metacíclicos por parte del vector invertebrado (Teixeira y col., 2013). 
Sin embargo, el proceso de inoculación de especies causantes de LV en la piel y los mecanismos que causan su visceralización sigue siendo un tema desconocido en muchos aspectos. Aunque se ha confirmado la rápida infiltración de los neutrófilos en la zona y la infección subsiguiente de macrófagos de la piel tras la inyección de promastigotes de L. infantum, no existe aún prueba de que estos eventos contribuyan a la infectividad de las especies viscerales o en su diseminación en órganos internos (Thalhofer y col., 2011). Es posible que la diseminación de las especies causantes de LV esté mediada por células infectadas de la piel u otro tipo de células o mediante la liberación de parásitos libres, promastigotes o amastigotes, hacia órganos cuya función principal es la de filtrar la sangre, como el bazo, estando evidenciada esta hipótesis por estudios en los que se encontraron amastigotes en el torrente sanguíneo de hámsteres infectados (Paraguai de Souza y col., 2001).

El modo en que los promastigotes interactúan con las células del huésped en primer lugar ha originado distintos estudios, muchos de ellos con resultados contradictorios entre sí. Muchos de ellos apuntaban a una entrada de los parásitos tanto por la zona anterior o posterior del flagelo (Chang, 1978; Courret, 2002), lo que parecía indicar una adhesión al azar por parte de los parásitos extracelulares y un proceso pasivo de infección, cuyo resultado final recaía directamente en la capacidad fagocitaria de las células del sistema inmune del hospedador. Forestier y colaboradores en el año 2011, establecen una entrada predominante de los parásitos a través de la punta flagelar. Además, dado que los parásitos muertos o inmovilizados no son capaces de invadir los macrófagos de forma eficiente, se sugiere que la fagocitosis de los parásitos responde a un proceso activo que requiere una interacción adecuada de los promastigotes vivos con la superficie de la célula huésped.

Los promastigotes metacíclicos son fagocitados por los macrófagos y encerrados en el interior de los fagosomas, compartimentos ácidos que expresan la Proteína de Membrana Asociada al Lisosoma 1 y 2 (LAMP), una glicoproteína que aporta selectinas con ligandos para carbohidratos, como es el caso del LPG de la superficie del parásito, y las catepsinas B, D, H y L (Lang y col., 1994). Esta internalización tiene lugar debido a la interacción del flagelo de la Leishmania con la superficie de la célula hospedadora. A continuación el parásito comienza a sacudirse dentro de la vesícula gracias al movimiento del flagelo primero hacia la periferia celular, con lo que consigue una ruptura de la membrana plasmática celular. Es entonces cuando los lisosomas proximales son reclutados hacia la zona y mediante exocitosis vuelven a sellar la membrana dañada y permiten que se finalice la formación completa de la vacuola que alberga a los parásitos. Finalmente, la movilidad del flagelo cesa y el fagolisosoma que contiene a la Leishmania se acerca al núcleo del macrófago donde pierde su capacidad de fusión (Forestier y col., 2011).

La forma metacíclica del parásito es capaz de resistir el efecto de los fagolisosomas gracias de nuevo a la presencia del LPG y de la proteína de superficie gp63 (Olivier y col., 2005) que degrada las enzimas lisosomales destinadas a destruir los parásitos (Lodge y Descoteaux, 2008). El LPG retarda la maduración del fagolisosoma, protege de las enzimas lisosomales y neutraliza las formas reactivas de oxígeno (ROS), mientras que las peridoxinas 1 y 2 y la superóxido dismutasa 
previenen la formación de ROS y óxido nítrico, molécula vital en la supervivencia o mortalidad de los parásitos intracelulares en el interior de las células infectadas. La diferenciación celular a la forma amastigote en el interior de las células hospedadoras supone una marcada reordenación ultraestructural en los parásitos (Akiyama y McQuillen, 1972), incluyendo la pérdida del flagelo y un cambio del LPG de la superficie celular (Moody y col., 1993). En el interior de las vacuolas parasitóforas los promastigotes se transforman a amastigotes y tiene lugar la fusión de los lisosomas y la vacuola parasitófora. Los amastigotes, resistentes al pH ácido de la vacuola se multiplicarán en su interior por fisión binaria generándose un número tan alto de parásitos intracelulares que la célula que los alberga se lisará liberándolos al espacio extracelular donde serán capaces de infectar nuevos macrófagos/monocitos de otros tejidos que podrán ser aspirados en otra succión de sangre por parte del vector invertebrado (Teixeira y col., 2013), volviendo así al inicio del ciclo vital de los parásitos del género Leishmania.

\subsubsection{Leishmaniosis: formas clínicas de la enfermedad}

El término leishmaniosis abarca diversos síntomas y formas clínicas de la enfermedad. En función de la especie implicada, tanto del Viejo como del Nuevo Mundo, y la respuesta inmune del hospedador (Pintado y López-Vélez, 2001), se han descrito cinco manifestaciones clínicas principales en el ser humano (Ashford, 2000):

Leishmaniosis cutánea (LC): Es la forma más común y está normalmente causada por distintas especies. En el Viejo Mundo los agentes etiológicos incluyen L. tropica, L. major y L. aethiopica; las principales especies en el Nuevo Mundo son las que conforman el complejo L. mexicana (L. mexicana, L. amazonensis y L. venezuelensis), o el subgénero (L) Viannia (L. panamensis, L. guyanensis, L. peruviana o $L$. braziliensis), pero puede estar causada por cualquier especie de Leishmania patogénica para el ser humano, como L. infantum o L. donovani.

* Leishmaniosis mucocutánea (LMC): Está causada normalmente por $L$. braziliensis, y aparece tras haber padecido LC.

* Leishmaniosis cutánea difusa (LCD): Dos especies aparecen como responsables de la enfermedad, L. aethiopica y L. amazonensis.

* Leishmaniosis visceral (LV): Puede afectar de manera restringida a niños, estando causada en este caso por L. donovani infantum o no presentar ningún tipo de especificidad por la edad del individuo, interviniendo $L$. $d$. donovani. L. d. infantum afecta a personas de todas las edades que padezcan algún tipo de enfermedad que cause un estado de inmunosupresión. Se ha sugerido la participación de L. tropica como agente causativo de LV.

* Leishmaniosis dérmica post kala azar (LDPK): Está causada por L. $d$. donovani, y los síntomas aparecen tras la cura aparente de la afectación visceral.

Las especies de Leishmania que producen manifestaciones cutáneas y mucocutáneas (dermotrópicas) son sensibles a temperaturas mayores a $35^{\circ} \mathrm{C} \mathrm{y} \mathrm{se}$ multiplican únicamente en áreas expuestas de la piel. Las especies que ocasionan las manifestaciones viscerales de la enfermedad (viscerotrópicas), requieren $37^{\circ} \mathrm{C}$ 
para su diferenciación a amastigotes, por eso migran a la médula ósea, al bazo y al hígado (Alvar, 2001). Todas las formas descritas pueden alternar entre afectaciones asintomáticas o severas; la LC y LMC pueden causar cierta morbilidad, mientras que la LV puede llevar a la muerte del individuo en ausencia de un tratamiento eficaz.

TABLA 1.2. Especies de Leishmania causantes de las formas clínicas más comunes de la enfermedad (McCall y col., 2013).

\begin{tabular}{lll}
\hline Fenotipo & Agente etiológico \\
\hline Leishmaniosis cutánea & spp. comunes & L. major \\
& & L. tropica \\
& & L. amazonensis \\
& & L. mexicana \\
& spp. raras & L. braziliensis \\
\hline Leishmaniosis mucocutánea & spp. comunes & L. braziliensis \\
\hline spp. raras & L. panamensis \\
\hline Leishmaniosis visceral & & L. guyanensis \\
\hline & spp. comunes & L. donovani \\
\hline & & L. infantum \\
& & L. chagasi \\
& & L. tropica \\
\hline & & L. amazonensis \\
\hline & &
\end{tabular}

\subsubsection{Leishmaniosis cutánea}

Si no se especifica, la LC hace referencia a la forma localizada de la enfermedad y no a otras formas menos frecuentes como la LC "difusa" o "diseminada". Típicamente en la LC tras la picadura del insecto, ésta persiste en el tiempo. De forma gradual la lesión inicial comienza a agrandarse, manteniendo un color rojizo, pero sin dolor aparente. La desaparición de la lesión incluye la migración de leucocitos, los cuales aíslan el área afectada permitiendo la necrosis de los tejidos infectados y la formación de un granuloma cicatrizante en el centro de la lesión. El proceso necrótico puede ser rápido, causando una úlcera relativamente grande, humedecida y abierta (característico de L. major, L. panamensis y L. braziliensis), o puede ser más indoloro sin una ulceración tan evidente (causado por las especies $L$. tropica, L. aethiopica, L. peruviana).

Las lesiones típicamente evolucionan desde pápulas a placas nodulares y a lesiones ulcerantes, las cuales suelen presentar un borde elevado y una depresión central de la zona; algunas lesiones persisten en el tiempo como nódulos.

La cura natural sin necesidad de tratamiento puede llevar más o menos tiempo en función de la especie de Leishmania involucrada y el lugar de la lesión. De forma similar, el tamaño de la lesión puede variar entre unos pocos milímetros a varios centímetros de diámetro. No es inusual, especialmente para las infecciones 
causadas por L. major, en las cuales pueden aparecer numerosas lesiones de forma simultánea o lesiones "satélite".

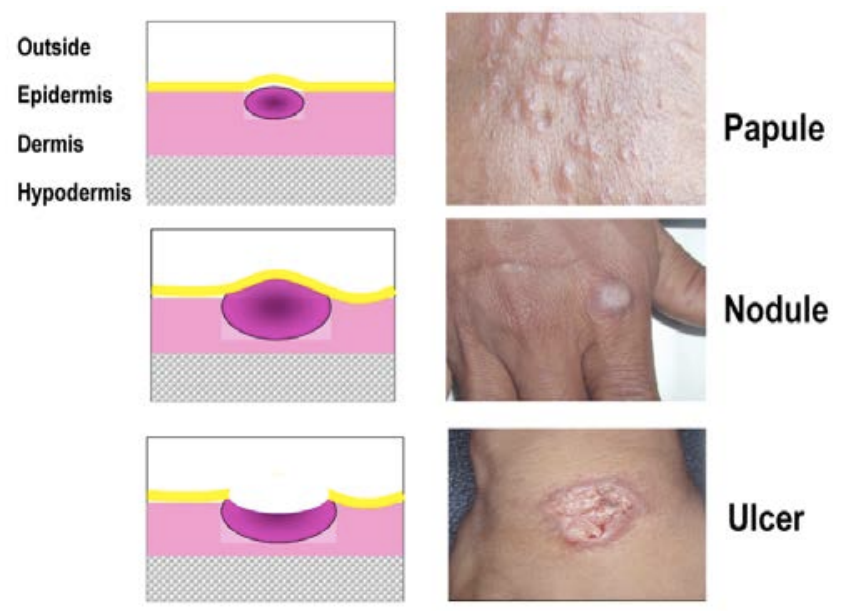

Figura 1.15. Formas típicas de la leishmaniosis cutánea (Olliaro y col., 2013).

La LC no se asocia normalmente con signos o síntomas sistémicos, pero los ganglios linfáticos drenantes de la región afectada pueden verse agrandados e inflamados y las lesiones pueden expandirse por los vasos linfáticos ( $L$. guyanensis); a veces la linfadenopatía se diagnostica antes de que las lesiones proliferen. Por su parte, la LC causada por L. tropica o L. major no genera una respuesta serológica detectable; previa a la cura de la zona, el test de la piel da positivo para estas especies. Los pacientes curados desarrollan una respuesta inmune eficaz a una infección homóloga durante varios años.

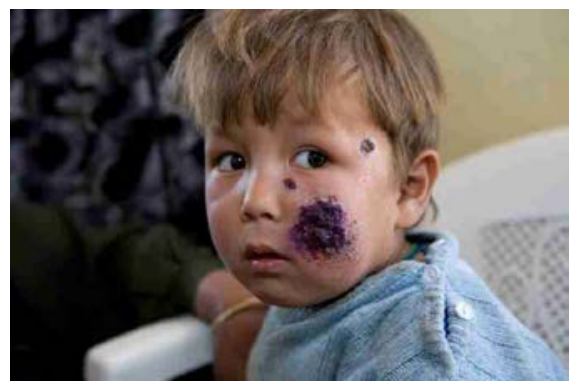

Figura 1.16. Niño con leishmaniosis cutánea esperando por tratamiento en Kabul, Afghanistán (OMS).

\subsubsection{Leishmaniosis mucocutánea}

La leishmaniosis mucocutánea (LMC) es una enfermedad mucho más dañina y está causada por especies del complejo L. braziliensis en el Nuevo Mundo y en algunos casos puede resultar mortal. La mayor parte de los casos son declarados en Sudán y otros focos del Viejo Mundo. Las lesiones se suelen localizar en el sitio de la 
picadura o zonas cercanas a las superficies mucosas. Se ha informado de casos de LMC con L. infantum como agente causal ocasional, habiéndose encontrado el parásito en las amígdalas o en la mucosa bucal, por lo que parece que la razón principal pudo ser la inhalación accidental de los insectos infectados (Ashford, 2000).

Sin embargo, la LMC clásica o "espundia" aparece como una secuela metastática de una infección cutánea curada aparentementetras, a veces varios años después, que resulta en una diseminación de los parásitos desde la piel hacia la mucosa orofaríngea. Las mucosas y los cartílagos asociados se erosionan gradualmente hasta que la mayor parte de la cara puede verse afectada, siendo una enfermedad altamente deformante. Se cree que un tratamiento sistémico adecuado de la LC inicial puede reducir el riesgo de la enfermedad mucosa consiguiente, aunque tanto la magnitud como los determinantes de contraer la infección (especie parasitaria y estado inmune del hospedador), que determinarán la enfermedad per se no se conocen en profundidad.
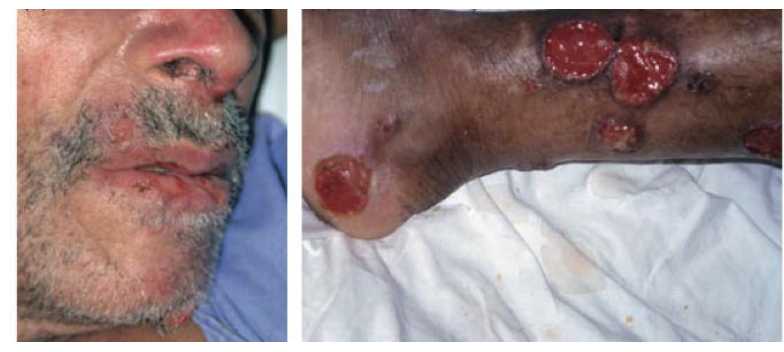

Figura 1.17. Lesiones causadas por la leishmaniosis mucocutánea. Pápulas y placas alrededor de la nariz y los labios causada por L. braziliensis. Úlceras en las piernas del mismo paciente (David y Craft, 2009).

\subsubsection{Leishmaniosis cutánea difusa}

La leishmaniosis difusa cutánea (LDC) está restringida en Venezuela y la República Dominicana en America Latina y en Etiopía y Kenia en el continente africano. Los primeros casos descritos en estos lugares fueron diagnosticados erróneamente como lepra lepromatosa. Se trata infección causada por parásitos responsables de LC simple, asociada con la existencia de una anergia específica o la ausencia de respuesta inmunológica adecuada (Ashford, 2000). Las lesiones pueden aparecer localizadas en una zona determinada o diseminarse por todo el cuerpo, siendo éstas indoloras en muchos casos pero altamente deformantes. Se caracteriza por la presencia de cantidades elevadas de parásitos en las zonas lesionadas.

\subsubsection{Leishmaniosis visceral}

La leishmaniosis visceral (LV) o "kala azar" está causada por L. donovani y $L$. infantum y afecta órganos internos tales como el hígado, el bazo, la médula ósea y los ganglios linfáticos. Es la forma más dañina de los distintos tipos de leshmaniosis, llegando a ser mortal en ausencia de tratamiento, debido a la enfermedad por si misma o a otras complicaciones como la hemorragia o infecciones bacterianas secundarias. Los signos sistémicos típicos como episodios 
irregulares de fiebre, anemia, esplenomegalia y hepatomegalia o la caquexia progresiva pueden aparecer tras semanas o incluso años después de la infección (Ashford, 2000). Otros síntomas incluyen la pérdida de peso, la linfadenopatía o la diarrea y la afectación del tracto gastrointestinal en pacientes coinfectados con el virus del SIDA.

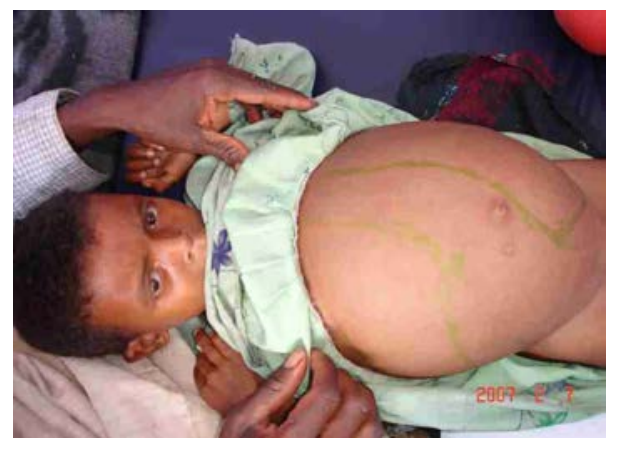

Figura 1.18. Niña infectada con leishmaniosis visceral en Etiopía. Las marcas en el abdomen indican signos de agrandamiento del bazo y el hígado (OMS).

Es una enfermedad mortal en ausencia de tratamiento, aunque se conocen casos de personas infectadas que se han recuperado espontáneamente, tal vez debido a que no desarrollaron la enfermedad en su totalidad (Ali y Ashford, 1994). La proporción de estos casos subclínicos varía desde el 100\% en infecciones causadas por L. infantum en adultos sanos, hasta menos del 25\% durante epidemias de kala azar en África. Aunque como se ha comentado, la LV puede llegar a ser fatal, está asociada con una respuesta serológica fuerte, de tal modo que el ratio albúmina/globulina se revierte al existir una hipergammaglobulinemia. El aumento de las proteínas séricas se emplea para realizar un diagnóstico no específico en el test de formol. Los casos curados tras el tratamiento presentan un resultado positivo al test de la piel, aunque se sabe que esta reacción puede desaparecer en pocos años.

\subsubsection{Leishmaniosis dérmica post kala azar}

La leishmaniosis dérmica post kala azar (LDPK) aparece como una secuela de la LV estando causada principalmente por L. donovani tras la finalización del tratamiento (6 meses o 1-2 años después), y la aparente curación de la enfermedad. Aunque existen algunos casos de LDPK de personas que no habían padecido LV con anterioridad (Hashim y col., 1995). Las personas afectadas de LDPK son consideradas una fuente potencial de infección de LV al actuar como reservorios del parásito.

La enfermedad comienza con la aparición de pequeñas máculas hipopigmentadas, pápulas o nódulos que aparecen en la cara y aumentan gradualmente de tamaño aunque no suelen alcanzar más de $1 \mathrm{~cm}$ de diámetro. Estas lesiones iniciales se extienden a la parte superior del tronco, los brazos, antebrazos, los muslos, las piernas, el cuello y la espalda. Estas múltiples lesiones pueden llegar a unirse formando lesiones más grandes lo que puede conducir a la ampliación de rasgos 
faciales como la nariz y los labios, dando una apariencia similar a la lepra. En estos casos la enfermedad puede llegar a ser altamente deformante, siendo particularmente grave si las lesiones se extienden a las superficies de la mucosa del tabique nasal, el paladar, la orofaringe o la laringe; si alcanza los párpados o la córnea, puede conducir a una ceguera permanente del individuo que la padece (Ramesh y col., 2008).

\subsubsection{Leishmania vs VIH}

En los últimos años la co-infección Leishmania-VIH está ganando importancia como una enfermedad emergente en regiones tropicales y subtropicales de todo el mundo, incluyendo Etiopía, Brasil, Sudán, India y el sur de Europa. En zonas con una alta prevalencia de leishmaniosis como son África y la India, la expansión de la enfermedad está alcanzando dimensiones de pandemia (Okwor y Uzonna, 2013). De hecho, se espera que el número de casos de co-infección aumente debido a la coincidencia de la distribución geográfica de las dos infecciones por separado (Cruz y col., 2006). En sudoeste de Europa existe una incidencia creciente de casos de co-infección (especialmente con LV) en países como Francia, Italia, España y Portugal.

De entre estos países, España posee el mayor número de casos de co-infección, lo que está relacionado con diversos factores como la reactivación de infecciones asintomáticas o el solapamiento geográfico de ambas infecciones en comparación con otros países europeos (Alvar y col., 2008). En nuestro país, un alto porcentaje de individuos asintomáticos obtienen resultados positivos en el test de la piel para Leishmania (Alvar y col., 1996), lo que indica su exposición repetitiva al parásito, aunque la respuesta inmune efectiva de estas personas evita la aparición y el desarrollo de la enfermedad. Además, cabe destacar que el 68\% de la personas coinfectadas eran drogodependientes, teniendo lugar la infección debido al empleo de las mismas jeringuillas infectadas entre varios individuos.

En el sur de Europa hasta el 70\% de los casos de LV en adultos están asociados con la infección con el VIH; de hecho, la co-infección con L. infantum se ha convertido en la tercera infección más frecuente en individuos infectados con el virus en zonas endémicas para la LV (Desjeux y Alvar, 2003). De hecho, se ha demostrado que la infección con el VIH aumenta el riesgo de desarrollar LV de 100 a 2.300 veces en áreas endémicas, reduce la probabilidad de una respuesta terapéutica efectiva con independencia del fármaco/s empleado/s (Marques y col., 2008), e incrementa en gran medida la posibilidad de recaída tras el tratamiento con una probabilidad del $52 \%$ (Sindermann y col., 2004). Estudios clínicos han revelado que la leishmaniosis promueve la carga viral y la progresión a padecer el Síndrome de Inmunodeficiencia Adquirida (SIDA), lo que reduce la esperanza de vida en los pacientes co-infectados. Ambos patógenos ejercen un efecto sinérgico en la reducción de las respuestas inmunes humorales y celulares al establecer la infección en los mismos tipos celulares del hospedador (Moreno y col., 2000). Además, en muchas ocasiones la curación de la leishmaniosis está relacionada con la persistencia de los parásitos en los sitios de infección y los ganglios linfáticos drenantes durante largos periodos de tiempo, lo que permitiría que la inmunosupresión causada por el virus (debido a la disminución de los linfocitos $\mathrm{T}$ CD4+), pudiera llevar a la reactivación de la infección parasitaria latente en estos individiuos inmunodeprimidos. 
El Virus de la Inmunodeficiencia Humana (VIH) es un virus ARN de doble cadena perteneciente a la familia Retroviridae. El virus infecta células del sistema inmune del hospedador, replicándose principalmente en el interior de los linfocitos T CD4+, macrófagos y células dendríticas, los cuales acaban siendo destruidos como consecuencia de la multiplicación del virus en su interior y su liberación al medio; esto conlleva la disminución drástica de este tipo de células, lo que resulta en un estado de inmunodeficiencia. Este estado de inmunosupresión aumenta la posibilidad de contraer infecciones oportunistas (Greene, 2007).

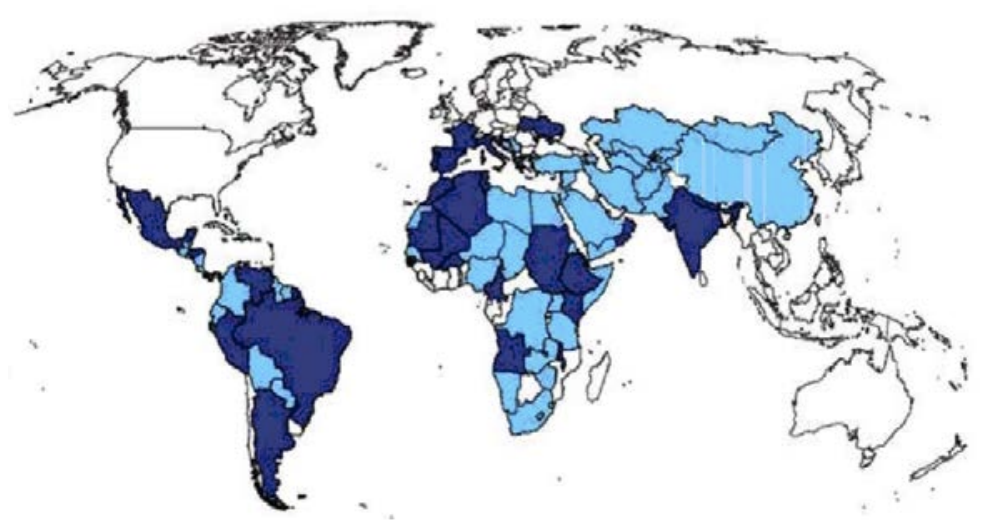

Figura 1.19. Distribución geográfica de países con leishmaniasis (azul claro) y países con casos de co-infección Leishmania-VIH (azul oscuro) (Desjeux y Alvar, 2003).

La existencia de ambos agentes infecciosos en la misma célula afecta la multiplicación de uno o ambos organismos (Bernier y col., 1995), ya que se cree que existe una relación de simbiosis entre los parásitos de Leishmania y el VIH. Leishmania estimula la activación crónica del sistema inmune, lo que resulta en el aumento de la carga viral con una progresión más rápida hacia padecer SIDA (Bentwich, 2003). Sin embargo, un estudio reciente realizado por el grupo de Santos-Oliveira y colaboradores (2010), demostró la activación del sistema inmune sin la necesidad del aumento de la carga viral en los pacientes coinfectados. De igual modo, la inmunosupresión causada por el VIH es muy favorable para la multiplicación descontrolada de los parásitos de Leishmania (Alvar y col., 2008).

Como ya se comentó anteriormente, Leishmania y el VIH infectan e interaccionan con las células dendríticas y los macrófagos del huésped, pero no sólo interaccionan a nivel celular sino también a nivel molecular (Murray y col., 2005). Sin embargo, se ha sugerido que Leishmania y el VIH actúen sobre las células dendríticas al modular moléculas de la superficie celular, inhibiendo su función, liberando al medio distintos factores solubles o retrasando la fusión de los lisosomas y las actividades citotóxicas intracelulares (Garg y col., 2007).

Cuando las células dendríticas y los macrófagos interaccionan con un antígeno, éstas procesan y presentan sus péptidos en la superficie y migran hacia los ganglios linfáticos drenantes más cercanos donde realizan la presentación antigénica a las células $\mathrm{T}$ colaboradoras naïve o linfocitos $\mathrm{T}$ "helper" CD4+ 
(Kedzierska y Crowe, 2002). El pérfil de citoquinas secretadas por los linfocitos Th polariza la respuesta inmune hacia una predominantemente citotóxica o celular (Th1) o hacia el otro extremo predominantemente humoral (Th2). Si el individuo presenta un sistema inmune fuerte y con capacidad de respuesta a pesar de la infección por Leishmania, las células T activadas secretarán citoquinas Th1 como el interferón gamma (IFN- $\gamma$ ) o la interleuquina IL-12; este perfil Th1 llevará a la destrucción del parásito mediada por la liberación de óxido nítrico en los macrófagos infectados (por la liberación de IL-2), la diferenciación de los linfocitos T citotóxicos o CD8+ (IFN- $\gamma$ ), o la producción de inmunoglobulinas por los linfocitos B (IL-12). En condiciones de co-infección con el virus VIH y, por tanto, de inmunosupresión, el balance inmune tenderá a generar respuestas de tipo Th2; el parásito no será capaz de activar a las células dendríticas y las células Th2 secretarán la interleuquina antiinflamatoria IL-4, activándose la respuesta humoral que llevará al progreso de la enfermedad como consecuencia de la ausencia de activación de los macrófagos que alberguen los amastigotes de Leishmania (Ezra y col., 2010).

Igualmente se ha demostrado que la infección con el VIH afecta a la fagocitosis y la replicación de los parásitos de Leishmania en el interior de los macrófagos; un ejemplo de ello es como la proteína transactivadora del VIH (Tat), aumenta la expresión de la prostanglandina E2, la ciclooxigenasa 2 y el factor de crecimiento transformante beta (TGF- $\beta$ ) en los macrófagos y las células dendríticas, lo que puede aumentar la replicación de los parásitos en estas células (Barreto-de-Souza y col., 2006).

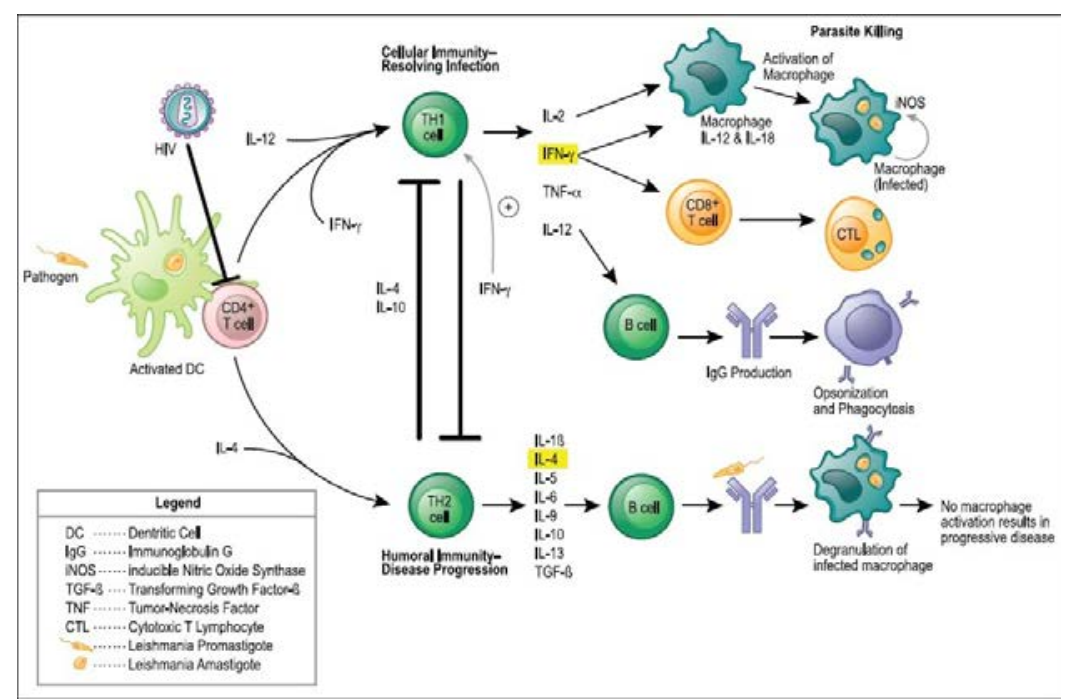

Figura 1.20. Balance inmunológico durante la co-infección del parásito Leishmania con el virus VIH (Ezra y col., 2010).

Un ejemplo de sinergia de la infección vírica es cómo los amastigotes de $L$. infantum promueven la proliferación del VIH en co-cultivos de células dendríticas humanas y linfocitos T CD4+ al inducir la secreción de las citoquinas IL-6 y el factor de necrosis tumoral alfa (TNF- $\alpha$ ) (Olivier y col., 2003). L. donovani puede 
también promover la replicación del cirus en células linfoides y monocíticas tanto in vitro como en individuos co-infectados. Sin embargo, no todas las especies de Leishmania se han encontrado en personas co-infectadas.

En este contexto, el LPG de la superficie de los parásitos de Leishmania juega un papel crítico en la supervivencia del parásito y el establecimiento de la infección en el interior de los macrófagos, modulando muchas de las funciones de estas células presentadoras de antígenos. Bernier y colaboradores (1995), demostraron como el LPG de L. donovani era capaz de regular positivamente la expresión del VIH empleando dos líneas celulares monocíticas que presentaban una infección vírica latente.

La alteración de las funciones efectoras de las células inmunes y, en general, el estado de inmunosupresión parece influir también en la reactivación de la enfermedad en pacientes co-infectados, como se ha observado en pacientes coinfectados con el VIH y especies cutáneas de Leishmania. Un paciente co-infectado con VIH y LC puede exhibir una presentación clínica de LC más grave de lo normal y atípica en cuanto a número de lesiones ( $>200$ ), laz zonas corporales y los tipos de lesión que presente (lesiones pápulonodulares o placas eritematosas) (Lindoso y col., 2009). Pueden aparecer lesiones en los genitales, el trato gastrointestinal o el tracto respiratorio (Piscopo y Mallia, 2006). Además, los pacientes co-infectados tienden a dar falsos negativos en el Test de Aglutinación Directa (TAD) empleado para detectar anticuerpos anti-Leishmania (Deniau y col., 2003), presentar altas cargas parasitarias en sangre y en la médula ósea, una baja sensibilidad a los tests serológicos y una tasa elevada de fallo del tratamiento (Niamba y col., 2007). En el caso de co-infección con LV, la típica esplenomegalia puede estar ausente (Paredes y col., 2003). Es interesante comentar que además de la inmunosupresión causada por el VIH, la leishmaniosis visceral es capaz de causar inmunosupresión por sí misma, lo que se ha relacionado con la inmunoregulación de la citoquina antiinflamatoria IL-10, encontrada en altos niveles en el suero de los pacientes infectados (Nylen y Sacks, 2007). En resumen, todos los descubrimientos e investigaciones de la co-infección de Leishmania y el virus VIH sugieren una regulación recíproca de la patogénesis de ambas enfermedades por los dos agentes infecciosos.

\subsection{RELACIÓN PARÁSITO-HOSPEDADOR}

\subsubsection{Mecanismos de evasión parasitaria en el vector invertebrado}

Existen barreras naturales del vector invertebrado al desarrollo de los parásitos en su interior durante los primeros días tras la ingesta de sangre, como los son la secreción de enzimas proteolíticas, la existencia de la matriz peritrófica que rodea y aísla la ingesta de sangre infectada y reacciones inmunes del propio flebotomo (Dostalova y Volf, 2012), todas ellas superadas por los parásitos de Leishmania en esta fase de su ciclo vital. Además, estos factores críticos representan dianas atractivas para evitar la transmisión de los parásitos desde el vector invertebrado, pudiéndose sintetizar moléculas específicas o fármacos que lo eviten. 


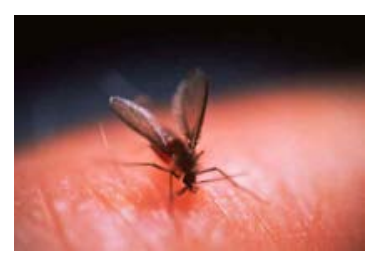

Figura 1.21. Imagen del vector invertebrado alimentándose de sangre humana (OMS).

En el intestino medio de los insectos apenas existe actividad proteolítica. La ingesta de sangre infectada produce un aumento de la actividad proteasa con un pico de actividad a las 18-48 h. Las principales proteínas involucradas son tripsinas y chimiotripsinas, habiéndose identificado en ensayos con inhibidores específicos y más recientemente, mediante secuenciación de ESTs (marcador de secuencia expresada) (Telleria y col., 2010; Dostalova y col., 2011). Las enzimas digestivas afectan al desarrollo de Leishmania en el vector invertebrado como han evidenciado distintos estudios en los que se mostraban cargas parasitarias bajas e incluso parásitos muertos en el interior de especies "no compatibles" de mosquitos durante las fases iniciales de la infección (Schlein y Jacobson, 1998). Pero también se ha observado que, incluso en el interior de vectores "compatibles", hasta el 50\% del inóculo inicial de amastigotes muere durante el primer día tras la ingesta de sangre (Rogers y col., 2002; Pimenta y col., 1997).

Por ello, los parásitos del género Leishmania han tenido que desarrollar mecanismos para luchar contra este ambiente hostil durante las fases iniciales en el insecto, tras la ingesta de la sangre infectada. Los grupos de Schlein y Romano (1986), y Dillon y Lane (1993), demostraron la habilidad de los parásitos de $L$. major para suprimir o retrasar los picos de actividad tripsina y aminopeptidasa en el intestino medio del vector; estudios de transcriptómica han determinado cómo los parásitos son capaces de controlar y modular la expresión de las proteasas del vector (Dostalova y col., 2011). Otro mecanismo por el cual los parásitos afectan la actividad proteolítica del intestino del insecto y que ha sido demostrado in vitro puede ser la expresión de inhibidores de serin-proteasas (ISPs), encontrados en $L$. major (Morrison y col., 2012).

Se ha postulado también la posibilidad de que Leishmania posea mecanismos que aumenten su resistencia al ataque proteolítico sin necesidad de inhibir la actividad de las enzimas del intestino del vector, como comprobaron Pimenta y colaboradores (1997), en estudios in vitro con lisados de la sangre ingerida por $P$. papatasi; este grupo estableció la resistencia de los amastigotes y los promastigotes totalmente diferenciados a las enzimas proteolíticas del vector. También se ha identificado moléculas que parecen jugar un papel en la defensa del parásito ante este ataque enzimático, como el LPG, el PPG o el sPPG (ver apartado 1.4) (Sacks y Kamhawi, 2001). El papel del PPG fue demostrado por Secundino y colaboradores (2010), los cuales identificaron esta molécula como clave en la resistencia al ataque proteolítico en los promastigotes procíclicos de L. major, ya que i) cepas delecionadas eran más susceptibles in vitro, ii) este efecto se revertía en parte mediante la adición de PPG purificado y iii) por la adición de inhibidores de tripsina al medio. 
La matriz peritrófica (MP) es una envuelta extracelular compuesta principalmente por quitina que separa físicamente el lumen intestinal del epitelio del intestino medio; una modificación de ésta es secretada por el epitelio intestinal en respuesta directa a la distensión que sufre dicho epitelio tras la ingestión de sangre (Shao y col., 2001), con el fin de rodear el bolo de sangre. Con el paso del tiempo la matriz se modifica en composición (se incluyen proteínas y glicoproteínas al esqueleto de quitina), hasta tener un aspecto más rugoso y comenzar a descomponerse (Sadlova y Volf, 2009). Diversos estudios establecen la función dual de la MP en el desarrollo de Leishmania; por un lado, protege los parásitos ante el ataque proteolítico y, por otro, actúa como una barrera que los paraliza. Por ejemplo, el bloqueo de la formación de la MP lleva al aumento del número de parásitos muertos de L. major en pocas horas tras la ingesta de sangre por P. papatasi (Pimenta y col., 1997); así la MP limita la exposición de los parásitos a la enzimas proteolíticas durante las fases iniciales de diferenciación parasitaria, cuando los parásitos son más vulnerables al daño enzimático. Sin embargo, durante las últimas etapas la MP parece actuar evitando el desarrollo de los parásitos. Walters y colaboradores (1992), observaron la paralización de L. panamensis en el espacio endoperitrófico de P. papatasi. Existen estudios que apoyan la idea de la sobreexpresión de una quitinasa del parásito para conseguir la evasión de la MP (Schlein y col., 1991; Rogers y col., 2008), aunque también los resultados de otros autores son ciertamente contradictorios; un ejemplo de ello es la inhibición de la quitinasa de Leishmania por la hemoglobina (Schlein y Jacobson, 1994). Existe cierta controversia en este aspecto, y parece ser que el mecanismo real por el cual los parásitos escapan de la MP al descomponerse ésta, no está completamente definido.

Por último, cabe destacar la existencia de proteínas y péptidos responsables de una respuesta inmune innnata en el intestino de insectos chupadores de sangre para controlar infecciones bacterianas y parasitarias (Hao y col., 2001; Feldhaar y Gross, 2008). Aunque la literatura en este aspecto es bastante limitada, se han descrito moléculas que reciben el nombre de "defensinas" en el intestino medio del insecto $P$. duboscqi, las cuales se inducen ante la presencia de bacterias o parásitos, en este caso, L. major (Boulanger y col., 2004). Recientemente, el grupo de Telleria (2013), ha analizado la expresión del gen que codifica una defensina en L. longipalpis, el vector natural de la LV en el Nuevo Mundo. Estos resultados sugieren que la activación de una respuesta inmune puede controlar el desarrollo de Leishmania en el vector invertebrado.

\subsubsection{Respuesta inmune y evasión en el hospedador definitivo}

Desde la entrada de los promastigotes metacíclicos en el torrente sanguíneo tras la picadura del insecto hasta que alcanzan su diana celular en el hospedador definitivo donde se transforman en amastigotes, existe una lucha que puede llevar al establecimiento de la enfermedad o, por el contrario, a la erradicación de los parásitos del organismo; ambos posibles destinos van a estar mediados en gran medida por la habilidad de los parásitos de Leishmania para evadir el sistema inmune del hospedador, tanto la inmunidad innata como el sistema inmune adaptativo (Gupta y col., 2013). El conocimiento de los mecanismos de evasión del sistema inmune del hospedador por los parásitos abre una vía importante para el desarrollo de tratamientos inmunoterapeúticos que puedan tener aplicación tanto 
a nivel preclínico como clínico en la cura de las leishmaniosis. La capacidad de Leishmania para mantener un estado crónico de la enfermedad radica principalmente en su potencial para evadir el sistema inmune del huésped. Estos mecanismos de lucha decidirán el destino del parásito en el interior del hospedador definitivo.

Uno de los principales mecanismos de evasión es la modificación del sistema del complemento. Los promastigotes metacíclicos previenen la inserción del complejo de ataque a la membrana haciéndolos altamente resistentes a la lisis mediada por complemento (Puentes y col., 1990), gracias a la modificación de la molécula de LPG durante la metaciclogénesis (Sacks y col., 1995). Estos parásitos poseen una expresión elevada de proteínas quinasa, las cuales fosforilan las proteínas C3, C5 y C9 del complemento, lo que resulta en la inactivación de las rutas clásica y alternativa (Hermoso y col., 1991). De la misma manera, la proteína de superficie gp63 es capaz de inactivar la proteína C3b a la forma C3bi en la superficie del parásito, impidiendo la formación de la convertasa C5 (Brittingham y col., 1995). La forma inactiva C3bi actúa también como una opsonina, facilitando una "entrada silente" de los parásitos en los macrófagos al unirse al receptor 3 del complemento (CR3) (Da Silva y col., 1989). Esta evasión facilitada por el receptor CR3 ha sido estudiada en ratones BALB/c deficientes, demostrándose la resistencia del hospedador a una infección de L. major en ausencia de la proteína (Carter y col., 2009).

Aunque los macrófagos son los responsables de la erradicación de los parásitos, también son las células en cuyo interior tiene lugar la proliferación del parásito. Ciertas moléculas de la superficie de Leishmania facilitan su reconocimiento por los macrófagos, la adhesión a los mismos y la consiguiente fagocitosis, como el LPG, la proteína gp63 o los GIPLs (Culley y col., 1996; Brittingham y col., 1995; Suzuki y col., 2002). Por su parte, los amastigotes de Leishmania pueden ser internalizados a través de las moléculas de fosfatidilserina y receptores Fc (Weingartner y col., 2012).
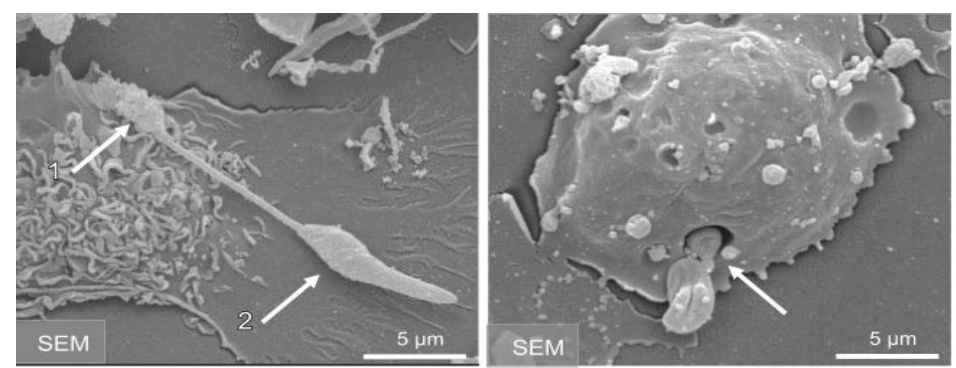

Figura 1.22. Imagen de microscopía electrónica de un promastigote y un amastigote de L. major siendo internalizados por macrófagos humanos (Wenzel y col., 2012).

Otro mecanismo por el cual los parásitos escapan del control del sistema inmune del huésped es la alteración de diversas rutas de señalización, como la ruta de los repectores de tipo Toll (TLR) o las cascadas de señalización celular. Los TLRs son receptores que se expresan en la superficie de las células de la inmunidad innata y 
tienen un papel crítico en el reconocimiento y la interacción inicial con los parásitos (Faria y col., 2012). Por ejemplo, el receptor TLR2 reconoce el LPG de los promastigotes, lo que resulta en la inducción de las citoquinas proinflamatorias TNF- $\alpha$ e IL-12, óxido nítrico y especies reactivas de oxígeno (ROS) para el control de la infección (Flandin y col., 2006; Kavoosi y col., 2009; Kavoosi y col., 2010). Sin embargo, L. major es capaz de reclutar moléculas que regulan negativamente la inducción de citoquinas por TLR2, como las proteínas SOCS-1 y SOCS-3 (de Veer y col., 2003). Leishmania ha desarrollado mecanismos para alterar las rutas de señalización de otros receptores tipo Toll, como es el caso de TLR4. Durante la infección de L. donovani, la activación de los macrófagos mediada por TLR4 es inhibida a través de la liberación de TGF- $\beta$, lo que favorece el establecimiento de la infección (Das y col., 2012), o el caso de la infección con parásitos de L. mexicana, los cuales bloquean la ruta de señalización de TLR4 al inhibir la producción de IL12 por los macrófagos infectados (Shweash y col., 2011).

Leishmania interfiere también con las cascadas de señalización celular que llevan a la síntesis de factores microbicidas, como es el caso de las especies reactivas de oxígeno (ROS), activadas por el complejo NADPH oxidasa (De Leo y col., 1996). En macrófagos infectados con $L$. donovani la activación de la NADPH oxidasa es bloqueada debido a la alteración de la ruta de señalización de la proteína quinasa $\mathrm{C}$ (PKC), inactivada a su vez por las moléculas de LPG de la superficie del parásito (Descoteaux y Turco, 1999). La síntesis de IFN- $\gamma$ es crítica para la destrucción de los amastigotes internalizados en los macrófagos infectados. El IFN- $\gamma$ activa la cascada JAK/STAT que lleva a la inducción de la síntesis de óxido nítrico, pero Leishmania es capaz de inactivar esta ruta cuando los promastigotes metacíclicos inactivan la proteína JAK2, lo que conlleva una disminución de la producción de óxido nítrico y, por tanto, la proliferación de los parásitos (Blanchette y col., 2009).

Como se comentó anteriormente, la supervivencia de los promastigotes metacíclicos en el interior de los macrófagos depende de la adaptación de los parásitos a las condiciones extremas de $\mathrm{pH}$, temperatura y el estrés oxidativo creadas por los fagocitos. Los promastigotes previenen la fusión del fagosoma y los lisosomas al retrasar o inhibir la maduración de los endosomas, lo que se ha observado por la expresión tardía de las proteínas Rab7 y LAMP-1 (Olivier y col., 2005; Scianimanico y col., 1999). El LPG de los promastigotes inhibe la maduración de los endosomas (Holm y col., 2001), y previene la acidificación del fagosoma, lo que facilita la transformación de los parásitos en amastigotes resistentes (Vinet y col., 2009). Leishmania también regula la proteína de tráfico lisosomal (LYST) para diluir el efecto del óxido nítrico, lo que resulta en la formación de vacuolas parasitóforas más grandes (Wilson y col., 2008).

Además, los amastigotes de Leishmania activan sus propios transportadores de hierro (LIT1 y LIT2), nutriente indispensable para su metabolismo y replicación, compitiendo así con el sistema de secuestro de hierro del hospedador (Kaye y Scott, 2011). Algo similar ocurre con la disponibilidad de arginina para los amastigotes, necesaria para la síntesis de poliaminas, pero indispensable para los macrófagos para la producción de óxido nítrico (Iniesta y col., 2002). La arginasa codificada en el genoma del parásito aporta nutrientes esenciales para su crecimiento y, además, atenúa el mecanismo de muerte parasitaria dependiente de la óxido nítrico sintasa inducible (iNOS) de los macrófagos, al competir con la 
arginina disponible en el interior de los fagocitos (Reguera y col., 2009). La interferencia con las rutas de señalización de las células del huésped permiten a varias especies de Leishmania modular el perfil de expresión de distintos tipos de citoquinas en su beneficio. Las citoquinas proinflamatorias, como IL-12, son esenciales para la generación de una respuesta inmune efectiva antes Leishmania; la síntesis de estas citoquinas suele ser suprimida por la entrada "silente" de los parásitos en los macrófagos (Belkaid y col., 2000). Por otra parte, IL-10, esencial para la supervivencia del parásito y la pogresión de la enfermedad es inducida por Leishmania en macrófagos y monocitos infectados (Chandra y Naik, 2008).

Además, Leishmania expresa ortólogos de citoquinas que modulan las células del sistema inmune; un ejemplo es un ortólogo de un factor inhibidor de la migración de los macrófagos producido por L. major, el cual inhibe la apoptosis del fagocito contribuyendo a la persistencia del parásito en su interior (Kamir y col., 2008). Además de la modulación de la expresión de citoquinas, los parásitos del genéro Leishmania son los responsables de alterar el perfil de expresión de quimiocinas y de los receptores de quimiocinas. En la leishmaniosis cutánea humana la forma difusa de la enfermedad se ha relacionado con la presencia de niveles bajos del factor quimiotáctico CCL2 (Ritter y col., 1996). Como CCL2 induce una actividad antiparasitaria en los macrófagos infectados, la inhibición de esta quimiocina por Leishmania podría facilitar su supervivencia. El LPG puede también inhibir la migración de los monocitos a través de la pared endotelial al inhibir la síntesis de CCL2 y la expresión de moléculas de adhesión, entre ellas la selectina E, ICAM-1 y VCAM-1 por las células endoteliales (Lo y col., 1998 184). También se ha descrito la inhibición de receptores de quimiocinas como CCR4 y CCR5, involucradas en la adhesión de los macrófagos, durante la infección con Leishmania (Pinheiro y col., 2006). Un estudio realizado por Katzman y Fowell (2008), mostró la inducción por L. major de la expresión de la quimiocina CCL7 en el lugar de la infección, permitiendo la acumulación de células $\mathrm{T}$ efectoras productoras de la citoquina antiinflamatoria IL-4, pero no IFN- $\gamma$. Por otra parte, en un modelo crónico de LV, $L$. donovani era capaz de inhibir la migración de las células dendríticas hacia zonas del bazo donde se concentran linfocitos $\mathrm{T}$, debido a una expresión atenuada del receptor CCR7. Además, la transferencia de células dendríticas que expresaban CCR7 en ratones infectados, reducía la carga parasitaria de forma significativa (Ato y col., 2002).

Leishmania posee también la habilidad de inhibir la presentación antigénica de las células del huésped a otros componentes del sistema inmune (Reiner y col., 1987). Esta capacidad es exclusiva de los promastigotes metacíclicos, ya que los macrófagos infectados con promastigotes procíclicos son capaces de presentar de forma eficiente el antígeno LACK (Courret y col., 1999). Otros estudios han mostrado que $L$. donovani inhibe la presentación antigénica al reprimir la expresión del complejo de histocompatibilidad de clase II (MHC II), de forma basal y particularmente tras la estimulación con IFN- $\gamma$ (De Almeida y col., 2003; Reiner y col., 1987). Acorde con la localización de los parásitos en el interior de los fagosomas, el MHC de clase II parece tener una mayor importancia que el MHC de clase I. Estudios realizados con ratones deficientes en el MHC de tipo I son resistentes a la infección por L. major, mientras que los ratones que carecen del MHC de tipo II se vuelven altamente susceptibles (Huber y col., 1998; Locksley y col., 1993). 
Por último, cabe destacar la capacidad de los parásitos de Leishmania para modificar y alterar las respuestas de las células T. La células Th1 juegan un papel vital en la eliminación de los parásitos a través de la secreción de IFN- $\gamma$ y CD40L, los cuales activan la producción de óxido nítrico por los macrófagos. Estudios recientes han demostrado que algunos factores secretados por L. major poseen propiedades inmunosupresivas, pudiendo alterar la capacidad de linfoproliferación de las células $\mathrm{T}$ y su polarización hacia un fenotipo susceptible Th2 (Tabatabaee y col., 2011). La habilidad de Leishmania para suprimir respuesta inmunes antiparasitarias por las células $\mathrm{T}$ reguladoras ha sido descrito en modelos animales de LV y LC, además de en el ser humano. Las células T reguladoras funcionan como reguladores de respuestas mediadas por células inmunes, previniendo el desarrollo de la patología debido a una actividad efectora de células $\mathrm{T}$ descontrolada. Aunque esto presenta aparentemente ventajas para el hospedador, también puede ser aprovechado por Leishmania al evitar la completa erradicación del parásito por las células Th1. Las células $\mathrm{T}$ reguladoras se encuentran recluidas en el lugar de la infección donde secretan IL-10 y TGF- $\beta$, los cuales regulan negativamente la respuesta Th1 y la actividad de los macrófagos (Peters y Sacks, 2006).

\subsection{INMUNOPATOGÉNESIS DE LA LEISHMANIOSIS: MODELOS ANIMALES}

Como se comentó anteriormente, las enfermedades conocidas como leishmaniosis presentan distintas manifestaciones clínicas que van desde infecciones asintomáticas o subclínicas, pasando por las formas cutáneas o mucosas altamente desfigurantes, hasta la enfermedad visceral, la cual es potencialmente fatal en ausencia de tratamiento. Este polimorfismo de la infección ha sido relacionado con la cepa de Leishmania, el inóculo inyectado, la ruta de infección, los efectos inmunorregulatorios de la saliva de la mosca y el fondo genético y la respuesta inmune del hospedador (De Almeida y col., 2003; Doherty y Coffman, 1996; Lang y col., 2003; Lima y Titus, 1996). Los aspectos inmunológicos de la enfermedad han sido estudiados en distintos modelos animales como el ratón, el hámster, el perro o los primates no humanos. Aunque estos modelos animales permiten tener control sobre la genética del parásito y del huésped empleados, ninguno de ellos reproduce fielmente los aspectos inmunopatológicos de la enfermedad humana, particularmente las formas asintomáticas y subclínicas, además de aquéllas que curan espontáneamente o las que cronifican en el individuo infectado, apareciendo éstos como reservorios (Handman, 2001).

El empleo de roedores salvajes, los cuales aparecen como reservorios primarios, podría ser muy interesante para elucidar su papel como reservorios naturales y para mejorar nuestro conocimiento sobre la relación parásito-hospedador, con el fin de extrapolar los resultados a la enfermedad humana. El empleo de modelos animales sigue siendo una alternativa adecuada para el diseño de estudios inmunológicos, ya que debido a consideraciones éticas no pueden ser realizados en el ser humano. Sin embargo, ningún modelo hasta la fecha es capaz de desarrollar todos las posibles infecciones con Leishmania spp. o reproducir completamente la enfermedad en el ser humano. Existen aún demasiadas incógnitas y preguntas sin responder que permitan encontrar estrategias para controlar la enfermedad o desarrollar programas eficaces de vacunación. 
El ratón de laboratorio debe gran parte de su popularidad como organismo modelo en la investigación biomédica a la existencia de gran cantidad de cepas consanguíneas, lo que supone el empleo de clones genéticos obtenidos tras generaciones de cruces entre hermanos; además, la diversidad genética entre las distintas cepas de ratón permite estudiar casi cualquier fenotipo (Szatkiewicz y col., 2008). Las infecciones experimentales con promastigotes de L. major han permitido elucidar los mecanismos que determinan la resistencia (cepa C57BL/6), o la susceptibilidad (cepa BALB/c) a la infección (Aguilar-Torrentera y Carlier, 2001); mecanismos relacionados con una respuesta inmune de tipo Th1 o Th2, respectivamente (Sacks y Noben-Trauth, 2002). La cepa C57BL/6 resiste la infección mediante la producción de IFN- $\gamma$ y TNF- $\alpha$ por las células Th1 CD4+, las cuales estimulan la síntesis de óxido nítrico que destruye los parásitos (Murray y Delph-Etienne, 2000). Por su parte, los ratones BALB/c desarrollan lesiones severas que llevan a una enfermedad progresiva y letal en muchos casos. Este fenotipo está asociado con una respuesta inmune Th2 caracterizada por la expresión aumentada de citoquinas antiinflamatorias como IL-4, IL-10 o TGF- $\beta$ (Roberts y col., 2005).

Sin embargo, el uso de distintas especies, diferentes sitios de inoculación (almohadilla plantar, oreja o base de la cola), y distintas dosis de promastigotes metacíclicos han llevado a una gran variedad de experimentos los cuales no reproducen exactamente la infección natural y, por ello, no permiten comparar con la infección humana. Debido a que en las infecciones naturales la mosca introduce en el hospedador un número bajo de parásitos junto con la saliva bioactiva, se están empleando dosis bajas de promastigotes metacíclicos mezclados con saliva del vector invertebrado en inyecciones intradérmicas en las orejas de los ratones, con lo que se consiguen lesiones que proliferan más rápidamente y alcanzan tamaños mayores (Belkaid y col., 1998).

Se ha demostrado que la pre-exposición frecuente a las picaduras del vector flebotomino no infectado protege contra la infección por L. major, estimulando la producción de anticuerpos neutralizantes contra las proteínas de la saliva del insecto (Rogers y col., 2009). Sin embargo, incluso para las mismas cepas de ratón se han identificado distintos factores de virulencia en función de la especie de Leishmania empleada en las infecciones experimentales. Por ejemplo, ratones C57BL/6 o C3H, los cuales son capaces de curar las lesiones causadas por L. major, desarrollan una enfermedad crónica al ser infectados con L. amazonensis o $L$. mexicana (McMahon-Pratt y Alexander, 2004). Es interesante comentar como las lesiones crónicas causadas por L. amazonensis en ratones C57BL/6 o C57BL/10 son independientes de la expresión de IL-4, típica de la respuesta Th2 (Jones y col., 2000). Estos resultados establecen las marcadas diferencias existentes entre las especies del Nuevo y del Viejo Mundo en cuanto a la interacción parásitohospedador y la respuesta inmune asociada a cada infección. El desarrollo de inmunoterapias o vacunas para el tratamiento de la LC no puede quedarse únicamente en el patrón de infección causada por L. major, sino que la inmunobiología asociada con otras especies de Leishmania debe tenerse en consideración. 


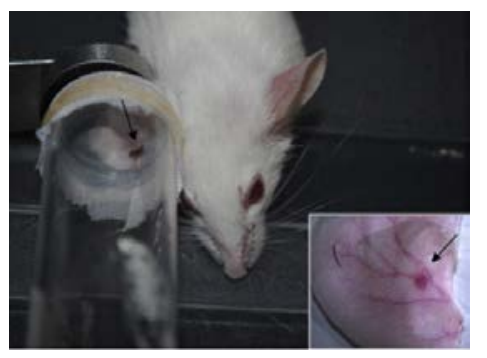

Figura 1.23. Infección experimental con el vector L. longipalpils infectado con L. infantum en la oreja de un ratón BALB/c. En el margen inferior se observa la picadura del insecto en la oreja diseccionada (Secundino y col., 2012).

De igual modo, se han empleado modelos animales basados en el uso de ratón para estudiar la LV causada por L. donovani y L. infantum. De entre las cepas de ratón más utilizadas, los ratones BALB/c son los más susceptibles aunque son capaces de controlar la enfermedad visceral al desarrollar una respuesta inmune específica del órgano afectado (Murray y col., 1982; Wilson y col., 2005). Durante las primeras semanas de infección los parásitos se multiplican principalmente en el hígado, pero 4 semanas después los ratones desarrollan una respuesta Th1, eliminan los parásitos y se vuelven resistentes a la reinfección, estando asociada la resistencia hepática a la aparición de granulomas (Beattie y col., 2010). Sin embargo, la infección persiste en el bazo y progresa durante un periodo de tiempo mucho más largo, incluso durante toda la vida del animal, lo que se relaciona con la ausencia de granulomas y una marcada esplenomegalia (Kumar y Nylén, 2012). Por ello, debido a que la infección visceral en ratones BALB/c es crónica y no fatal, sería más apropiado emplear este modelo para estudiar la infección subclínica, porque aunque es cierto que no permite una extrapolación exacta con la infección subclínica en humanos, ha sido útil en la identificación de genes de resistencia, como el gen $N R A M P 1$, el cual se expresa en la membrana de los macrófagos infectados de los ratones BALB/c y restringe la multiplicación de los amastigotes al aumentar el efecto de la iNOS (Blackwell y col., 2011).

Otro modelo animal empleado es el hámster sirio (Mesocricetus auratus), el cual es altamente susceptible a las infecciones con L. donovani y L. infantum y se considera el mejor modelo para estudiar la LV, ya que reproduce las características clínicas y patológicas de la enfermedad humana. Sin embargo, el uso del hámster presenta problemas debido a la falta de anticuerpos, citoquinas o marcadores celulares disponibles para estudiar la respuesta inmune de la enfermedad (Gupta y Nishi, 2011; Melby y col., 2001). En este sentido, las secuencias de genes codificantes de citoquinas en el hámster (IL-2, IL-4, IFN- $\gamma$, TNF- $\alpha$, IL-10, IL-12 y TGF- $\beta$ ), fueron clonadas para analizar su expresión. Este modelo de infección se caracteriza por la expresión temprana y aumentada de citoquinas típicas Th1 (IL-2 e IFN- $\gamma$ ). La expresión de la citoquina antiinflamatoria IL-10 aumenta en el bazo durante las primeras cuatro semanas de infección lo que sugiere que esta molécula puede contribuir a la aparición de la enfermedad progresiva en el hámster (Melby y col., 1998). Durante la infección progresiva tiene lugar una replicación incontrolada de los parásitos en el hígado, el bazo y la médula ósea, lo que puede explicarse, en parte, por la supresión de la respuesta linfoproliferativa (Goto y Prianti, 2009). 
También se ha relacionado la infección con L. donovani con la incapacidad de las células presentadoras de antígeno (APCs) de estimular células T, la producción de TGF- $\beta$ que genera la muerte apoptótica de los linfocitos y la desregulación de la actividad de la proteína quinasa C (Rodrigues Júnior y col., 1992; Banerjee y col., 2010; Mookerjee y col., 2003). Además, el resultado fatal de la enfermedad se ha relacionado con la pérdida de funciones efectoras por parte de los macrófagos. Así, la falta de producción de óxido nítrico se debe a un defecto en la activación transcripcional de la enzima NOS2, y al igual que el promotor humano NOS2, el mismo promotor en el hámster tiene una actividad basal e inducida por IFN$\gamma /$ LPS bajas, lo que no ocurre en el promotor murino. Esta parece ser la causa más probable de la falta de control de la infección parasitaria en el hámster (Perez y col., 2006). Hasta la fecha, la enfermedad progresiva en el hámster ha sido desarrollada mediante dosis infectivas elevadas e inyecciones intravenosas, intracardiacas o intraperitoneales, las cuales no mimetizan las condiciones naturales de infección. La inmunización con 16 plásmidos que codificaban para proteínas salivares permitió la identificación de la proteína LJM19, la cual protegía al hámster del resultado fatal de la LV causada por L. infantum. La posterior inmunización de los animales con la proteína LJM19 mantenía cargas parasitarias bajas, relacionadas con un ratio elevado entre IFN- $\gamma /$ TGF- $\beta$ y una expresión elevada de la iNOS en el hígado y el bazo tras cinco meses de infección (da Silva y col., 2011).

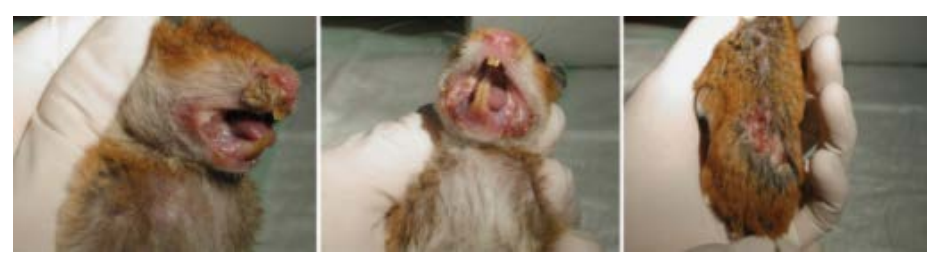

Figura 1.24. Lesiones externas en hámsteres sirios infectados con $10^{7}$ promastigotes de $L$. infantum tras siete meses de infección.

En el estudio de la leishmaniosis es inevitable no hacer referencia al perro como principal reservorio de LV causada por L. infantum en la zona mediterránea, Oriente Medio, las regiones asiáticas o América Latina. La leishmaniosis visceral canina es una enfermedad multisistémica caracterizada por la aparición de síntomas clínicos variables. Algunos perros infectados desarrollan una fuerte infección que puede acabar en la muerte del animal, mientras que otros se mantienen asintomáticos o desarrollan uno o más síntomas leves que los clasifica como oligosintomáticos (Ciaramella y col., 1997). La enfermedad se caracteriza desde un punto de vista histopatológico en la piel, hígado y bazo por una reacción inflamatoria granulomatosa asociada con la presencia de amastigotes en los macrófagos (Baneth y col., 2008). Estudios realizados en perros infectados experimentalmente han demostrado que después de tres años, tanto los animales asintomáticos como los resistentes son capaces de responder a antígenos de $L$. infantum en ensayos de linfoproliferación in vitro $\mathrm{y}$ en reacciones de hipersensibilidad, aunque no existen anticuerpos específicos en el suero de los mismos. 
El mecanismo principal involucrado en la respuesta inmune protectora en perros infectados con L. intantum es la activación de los macrófagos por la síntesis de IFN$\gamma$ y TNF- $\alpha$, lo que lleva a la muerte parasitaria mediante la producción de óxido nítrico (Vouldoukis y col., 1996). La respuesta local de citoquinas en perros infectados de forma natural con L. infantum ha sido estudiada, revelándose una acumulación de transcritos de IFN- $\gamma$ que ha sido correlacionado con una respuesta humoral (IgG1) a los antígenos del parásito. Además, otros estudios han descrito la existencia de un perfil mixto de citoquinas con niveles elevados de IFN- $\gamma$, TNF- $\alpha$ e IL-13 en la piel de perros asintomáticos infectados de forma natural. De igual modo, la enfermedad asintomática ha sido relacionada con niveles elevados de expresión de factores de transcripción como GATA-3 o FOXP3 (Menezes-Sousa y col., 2011), o el papel de los linfocitos T CD8+ citotóxicos, ausentes en animales susceptibles (Pinelli y col., 1995). Otro aspecto importante a tener en cuenta es la infección de perros domésticos con especies cutáneas de Leishmania, como $L$. braziliensis, L. peruviana, L. panamensis, L. colombiensis y L. mexicana en el Nuevo Mundo (Dantas-Torres, 2009), aunque hasta la fecha no hay pruebas sólidas de que el perro actúe como reservorio de la LC (Reithinger y Davies, 1999).

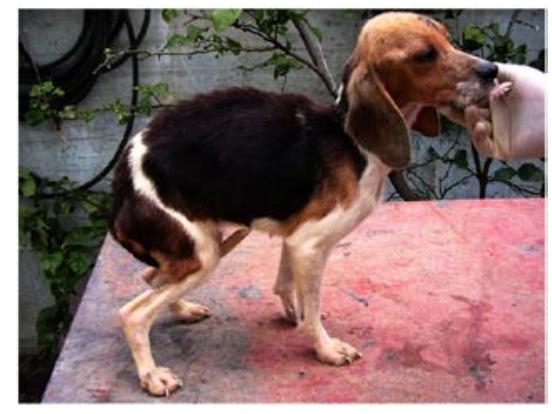

Figura 1.25. Pérdida de peso severa y atrofia muscular causada por la infección con L. infantum en un Beagle tras 18 meses desde la infección natural (Foglia Manzillo y col., 2013).

El último modelo animal empleado en el estudio de la leishmaniosis es el uso de primates no humanos; estos animales constituyen modelos valiosos en la investigación biomédica debido a su parecido en aspectos anatómicos, inmunológicos y fisiológicos con el ser humano. El empleo de primates no humanos como modelo de leishmaniosis está limitado por razones éticas y económicas (Real Decreto 53/2013 que ampara y protege a los primates no humanos en experimentación animal); su uso sólo puede estar justificado en aquellos casos en los que otros modelos animales no puedan emplearse. Estos animales son normalmente los últimos empleados en experimentación, principalmente para estudios de seguridad y eficacia de vacunas y nuevos fármacos. Sin embargo, existen estudios que evidencian la susceptibilidad de estos animales ante infecciones con Leishmania, como el empleo de macacos asiáticos (Macaca mulatta), los cuales desarrollan una enfermedad similar a la humana, poseen anticuerpos anti-Leishmania, respuestas inmunes de células T tanto in vitro como in vivo y una protección efectiva ante estudios de vacunación (Grimaldi Jr, 2008). La progresión y la resolución de las lesiones cutáneas causadas por especies como L. amazonensis o L. braziliensis son bastante similares a las encontradas en el 
ser humano, caracterizadas por la presencia de células T CD4+ y CD8+ productoras de IFN- $\gamma$, TNF- $\alpha$ e IL-10 y la presencia de granulomas (De Campos y col., 2010; Souza-Lemos y col., 2011). Los macacos han sido empleados en el estudios de las infecciones con L. major; los animales infectados desarrollan lesiones cutáneas simples que progresan hacia úlceras y una resolución completa tras unos tres meses de infección, lo que se asocia con una inflamación crónica específica y una reacción granulomatosa.

Además, estos animales adquieren distintos niveles de resistencia contra reinfecciones homólogas, como ocurre en el ser humano. Por ello, la importancia de este modelo para el estudio de la LC radica en la reproducción de los aspectos clínicos e histopatológicos comunes en las infecciones humanas con L. major y en la resistencia a las infecciones secundarias, lo que indica el desarrollo de la inmunidad adquirida (Amaral y col., 2001). Otros primates procedentes del Nuevo Mundo como los micos nocturnos (Aotus trivirgatus), los monos ardilla (Saimiri sciureus) o los titíes (Callithrix jaccus jaccus), se han considerado hospedadores potenciales para el estudio de la LV. Los micos nocturnos desarrollan una enfermedad visceral caracterizada por la pérdida de peso, anemia y hepatoesplenomegalia y una alta susceptibilidad a la infección por L. donovani (Broderson y col., 1986). Por otra parte, el mono ardilla desarrolla una LV al infectarse con $L$. donovani pero es capaz de recuperarse y resistir la infección (Dennis y col., 1986).

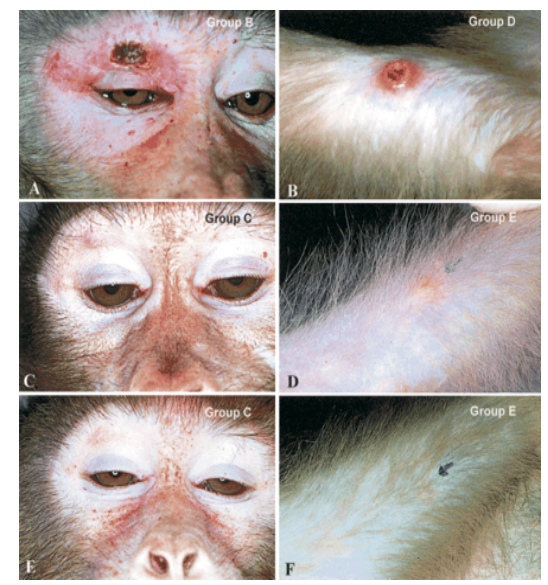

Figura 1.26. Nivel de protección cruzada en macacos entre distintas especies de Leishmania $(L$. amazonensis -grupos A y B-, L. guyanensis -grupo C y D-, y L. braziliensis -grupo E y F-), inoculadas tras 11 semanas de la infección inicial con L. major (Porrozzi y col., 2004).

Aunque no se conoce demasiado sobre la respuesta inmune a la infección en monos, hay diversos estudios en los que se ha evaluado la eficacia de vacunas. En macacos se ha estudiado la seguridad, la inmunogenicidad y la eficacia de una vacuna inactivada de L. amazonensis combinada con la presencia de la citoquina humana recombinante IL-12 (rhIL-12), y un hidróxido de aluminio en gel como adyuvantes. La vacunación por vía subcutánea fue segura y generó una respuesta inmune eficaz aunque en el sitio de vacunación se observó la aparición de un pequeño nódulo que desapareció con el tiempo (Kenney y col., 1999). Igualmente, 
se ha intentado reproducir la LV humana debido a L. donovani en monos verdes (Chlorocebus pygerythrus), observándose infecciones sintomáticas y asintomáticas (Gicheru y col., 1995).

En conclusión, los futuros esfuerzos para obtener modelos animales que mimeticen la enfermedad humana deberían incluir el uso de dosis infectivas bajas, el empleo de salivas de los vectores invertebrados con una alta carga en componentes bioactivos para realizar las infecciones experimentales, o el empleo reservorios naturales, todo ello con el fin de ampliar nuestro conocimiento de las leishmaniosis y evaluar posibles tratamientos, inmunoterapias o vacunas.

\subsection{TRATAMIENTO DE LA LEISHMANIOSIS Y APARICIÓN DE RESISTENCIAS}

En estos últimos años, debido a la crisis en el ámbito de la investigación y la innovación en la industria farmacéutica y, en concreto, la ausencia de nuevos fármacos diseñados específicamente contra las "enfermedades desatendidas" (EDs) que afectan a los países menos desarrollados del planeta, se ha convertido en un problema que preocupa a nivel mundial (Chirac y Torreele, 2006). Desde 1975 hasta 2004, 1.556 nuevos fármacos fueron comercializados y de entre ellos tan sólo 21 iban dirigidos a tratar las principales enfermedades infecciosas humanas, destacando la miltefosina como el primer fármaco oral para el tratamiento de la leishmaniosis.

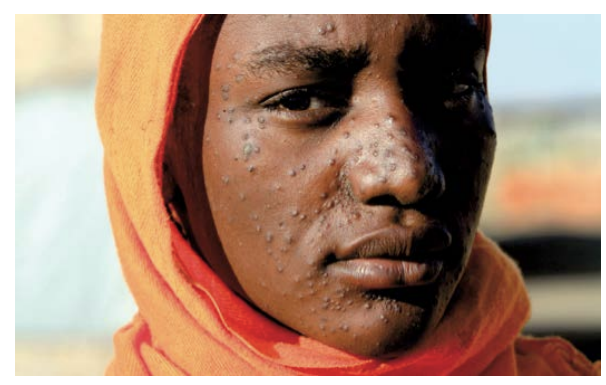

Figura 1.27. Erupción típica causada por le leishmaniosis visceral o kala-azar (Hayden, 2014).

Estos números representan el $1 \%$ de los nuevos medicamentos lanzados al mercado por las grandes empresas farmacéuticas en este periodo de 30 años (Troullier y Olliaro, 1999). Un informe de la Organización Mundial de la Salud en el año 2012 estableció que si todos los países invirtieran el 0,01\% de su Producto Interior Bruto (PIB) en estas enfermedades desatendidas, se doblaría el presupuesto disponible hasta los 6 billones de dólares anuales; actualmente sólo Estados Unidos lo está llevando a cabo y otras economías emergentes como China, Brasil y la India han aumentado su inversión (Hayden, 2014). Sin embargo, sigue existiendo una gran disparidad entre el gasto en $\mathrm{I}+\mathrm{D}+\mathrm{i}$ para tratar las enfermedades de los "ricos" como el cáncer o el infarto de miocardio, y las que padecen las poblaciones más pobres del planeta, a pesar de los esfuerzos llevados a cabo por organizaciones como el DNDi (Drugs for Neglected Diseases Initiative) o la Fundación Bill \& Melinda Gates. 


\subsubsection{Quimioterapia actual y pasada}

El acceso a las medicinas disponibles para el tratamiento de la leishmaniosis sigue siendo un desafío en los países más pobres del planeta, los cuales tienen los mayores índices de infección. Muchos de estos países endémicos para la enfermedad, poseen sistemas sanitarios deficientes $y$, en muchos casos, inexistentes, lo que agrava la situación. El control de la infección por Leishmania spp. se ha basado principalmente en la quimioterapia al no existir hasta la fecha una vacuna y/o programas de control del vector flebotomino eficaces. En la actualidad todo el subcontinente de la India presenta resistencia a los antimoniales pentavalentes, los cuales han sido los fármacos de elección en el tratamiento de la LC y la LV durante décadas debido a que son los únicos que tienen un precio asequible (Sundar y col., 2002). En la India hay unos 200 millones de personas en riesgo de contraer la leishmaniosis, lo que supone el $67 \%$ de la población mundial en riesgo (Chappuis y col., 2007). En esta región la disponibilidad de fármacos antiLeishmania sin coste alguno para el paciente aumenta las probabilidades de realizar un empleo erróneo de los mismos, lo que incrementa la aparición de resistencias (Croft y col., 2006). La segunda línea de fármacos disponibles para tratar la LV incluyen la anfotericina B o la pentamidina. Otras medicinas que se administran por vía oral como la miltefosina o el fluconazol se han empleado en el tratamiento de la LV y la LC, respectivamente. Sin embargo, estos fármacos de segunda línea se emplean con menor frecuencia en los países en desarrollo debido a su elevado coste, los efectos secundarios y la necesidad de hospitalizar al paciente. Por tanto, existe una necesidad real y urgente de desarrollar nuevos fármacos anti-Leishmania que permitan un uso preventivo y profiláctico de los mismos, con el fin de conseguir reducir los casos de infección en estas zonas endémicas, empobrecidas y debilitadas.

Desde hace más de 60 años los antimoniales pentavalentes como el estibogluconato de sodio (Pentostam), siguen siendo la principal vía de tratamiento de la leishmaniosis. El mecanismo de acción no se conoce con claridad, pero se sabe que la forma pentavalente es inactiva frente a Leishmania spp. En el interior del macrófago la molécula se reduce a la forma trivalente al emplear los tioles del parásito y de la superficie de la célula de mamífero, actuando por tanto sobre los amastigotes intracelulares (Singh, 2006). En 1920 el científico indio Bramhachari sintetizó por primera vez el antimonio pentavalente y lo empezó a emplear como quimioterápico en el tratamiento de la LV (Haldar y col., 2011). Inicialmente una dosis de $10 \mathrm{mg} / \mathrm{Kg}$ durante 6-10 días conseguía una cura clínica del $90 \%$ en los pacientes infectados de LV. Con el tiempo se aumentó la dosis y se prolongó el tratamiento ( $20 \mathrm{mg} / \mathrm{Kg}$ durante 30 días), aunque ya no se pudo evitar la aparición de resistencias; por el contrario, se comenzaron a seleccionar cepas cada vez más resistentes, alcanzando dimensiones de epidemia en Bihar (India) como la consiguiente diseminación al resto del subcontinente debido a la transmisión antroponótica (Mishra y col., 1992). Aunque actualmente el empleo de los antimoniales en la India está prohibido, se emplean como fármacos de primera línea en las zonas endémicas de todo el mundo. La sensibilidad varía con la especie de Leishmania; L. braziliensis es más sensible en comparación con L. mexicana, por ejemplo (Navin y col., 1992). Algunos de los factores responsables de la resistencia al tratamiento en el hospedador incluyen i) una disminución en la absorción de la droga; ii) la presencia de una concentración baja de la misma en el interior de los 
macrófagos; iii) la inhibición de la activación del compuesto; iv) la inactivación de la forma activa o v) un metabolismo aumentado de los grupos tiol, ya que e exceso la molécula de tiol incrementa el estrés oxidativo previniendo la formación de la especie trivalente activa (Haldar y col., 2011).

Otro compuesto ampliamente empleado en el tratamiento de los pacientes infectados con Leishmania es la anfotericina B, un antifúngico poliénico sintetizado por la bacteria Streptomyces nodusus, y considerado tratamiento de segunda línea. Está disponible en dos formas principales, la anfotericina B clásica y la anfotericina B liposómica (AmBisome), siendo ésta última mejor tolerada y menos tóxica (Sundar y col., 2010). La anfotericina B presenta un mecanismo de acción multifacético, presentando distintas dianas terapéuticas. La molécula se une a las moléculas de esterol y forma poros en la membrana celular permitiendo la fuga del contenido celular seguido de la muerte de la célula. También participa en la generación de especies reactivas de oxígeno (ROs), las cuales dañan la célula hasta su completa destrucción. Esta molécula aparece como un quimioterápico eficaz contra la leishmaniosis aunque existen algunos estudios que indican la aparición de resistencias al tratamiento, sobre todo en la India. Purkait y colaboradores (2012), establecieron un mecanismo a nivel molecular para explicar la aparición de resistencias. El grupo describió como los esteroles de la superficie de los amastigotes de las cepas resistentes eran reemplazados por un precursor debido a un error en el proceso de trans-metilación de la enzima SCMT, de la cual existen dos isoformas, SCMT A y SCMT B (S-adenosil-l-methionina:C-24- $\Delta$-sterolmetiltransferasa); en las cepas resistentes los transcritos de la SCMT A están ausentes. Esta alteración de la composición de la membrana causa una disminución de la unión de las moléculas de anfotericina $\mathrm{B}$ y, por tanto, de su inclusión en la célula. Igualmente se ha descrito una expresión aumentada de los genes MDR1 de los transportadores $\mathrm{ABC}$ en las cepas resistentes y una regulación exacerbada de las ROs. El efecto acumulativo de todos estos procesos puede disminuir la concentración de anfotericina B en el interior celular, contribuyendo a su resistencia.

Por su parte, la miltefosina (hexadecilfosfocolina), fue el primer fármaco oral para el tratamiento de la LV con un $94 \%$ de éxito en la cura de la enfermedad (OMS, 2010). Ha demostrado ser eficaz en casos de pacientes de LV y LDPK resistentes al antimonio (Ramesh V. y col., 2008), siendo el tratamiento de primera línea en la India para el control de la LV (Joshi y col., 2008). Su mecanismo de acción no se conoce en profundidad; la molécula de miltefosina se une a la membrana celular y es internalizada mediante dos proteínas de membrana descritas en cepas como $L$. donovani, el transportador de miltefosina (LdMT) y la proteína Ros3 (LdRos3) (Maltezou, 2010), alterando el metabolismo lipídico del parásito y causando la muerte por apoptosis. Sin embargo, debido a la transmisión antroponótica en la India, su uso abusivo y su elevada vida media, la aparición de resistencias preocupa en la actualidad, ya que se han descrito casos de personas resistentes en Nepal (Pandey y col., 2012). Parece ser que el mecanismo de resistencia es la inactivación de los genes responsables de la internalización de la miltefosina en la célula ( $L d M T$ y $L d R o s 3$ ), en los que mutaciones puntuales causan una respuesta variable al tratamiento con la droga. Sin embargo, no se han encontrado diferencias genómicas en estos genes entre las cepas sensibles y las resistentes, por lo que otros factores deben estar involucrados en el mecanismo de resistencia. 
Otro compuesto quimioterápico frente a varias especies de Leishmania es el antibiótico de amplio espectro paromomicina, sintetizado por $S$. rimosus. En el año 2002 fue introducido como droga anti-Leishmania en la forma de paromomicina sulfato (Williams y col., 1998) Se considera un candidato potencial a convertirse en fármaco de primera línea para el tratamiento de la LV al estar caracterizado por su bajo coste, pocos efectos secundarios, buena eficacia y tiempos cortos de administración (Sundar y col., 2009). La paromomicina pertenece al grupo de los antibióticos aminoglicósidos por lo que su mecanismo de acción es la inhibición de la síntesis proteica. Parece ser que existe probabilidad de adquirir resistencia al tratamiento único con paromomicina sulfato; actualmente nuevas formulaciones como la paromomicina sulfato encapsulada en microesferas de albúmina o la paromomicina sulfato liposomal están exhibiendo mejores resultados que la molécula original (Khan y col., 2013).

Entre los fármacos de segunda línea destaca la pentamidina, una diamina aromática empleada en el tratamiento de la LV en forma de sales de isotionato y metasulfonato. Se empleó inicialmente para tratar a pacientes refractarios tras el tratamiento con antimoniales pentavalentes en la India, aunque finalmente su uso fue reducido debido a la falta de eficacia y el alto riesgo de adquirir resistencias. Parece funcionar mejor en combinación con otros fármacos. El grupo de Das (2001), llevó a cabo un estudio en un paciente que no respondía al tratamiento con antimoniales, el cual fue tratado con una combinación de una dosis baja de pentamidina y alopurinol; este esquema de tratamiento resultó en una mejor efectividad, una menor toxicidad y una cura del 73\%. Además, su efectividad depende de la especie de Leishmania a combatir, siendo eficaz en infecciones con $L$. panamensis o L. guyanensis (Reveiz y col., 2013), pero no en pacientes infectados con L. braziliensis en Perú (Andersen y col., 2005). Aunque el mecanismo de acción no se conoce de forma precisa, hay estudios que atribuyen su entrada en los parásitos de L. donovani a través de transportadores de arginina y poliaminas (Kandpal y Tekwani, 1997). Este compuesto se acumula en la mitocondria y aumenta la eficacia de los inhibidores de la cadena respiratoria mitocondrial, con lo que se disminuye su potencial de membrana; también se ha descrito su papel como inhibidor de la topoisomerasa mitocondrial de tipo II (Basselin y col., 1998). La adquisición de resistencias al tratamiento con pentamidina no está descrito en su totalidad pero en los amastigotes la proteína PRP1 de los transportadores ABC juega un papel importante (Coelho y col., 2007).

Existen otros fármacos empleados en clínica como los azoles, el alopurinol o el sitamaquine. Los imidazoles y triazoles son antifúngicos que poseen actividad leishmanicida contra ciertas especies al interferir en la biosíntesis de esterol de la membrana celular del parásito. Destacan el fluconazol, empleado frente a infecciones con L. major (Alrajhi y col., 2002), o el ketoconazol en infecciones de $L$. panamensis y L. mexicana (Saenz y col., 1990). La actividad anti-Leishmania del alopurinol, un análogo de la purina, fue descubierta hace 30 años. La molécula es sustrato de distintas enzimas de la ruta de las purinas en tripanosomátidos, y se incorpora selectivamente a los ácidos nucleicos del parásito. Debido a su biodisponibilidad oral, el fármaco ha sido candidato en ensayos clínicos de LV y LC en humanos, pero sin demasiado éxito. Sin embargo, en los últimos años se ha considerado como terapia de mantenimiento en la leishmaniosis canina (Koutinas y col., 2001). Por otra parte, el sitamaquine (WR6026), es un análogo 
aminoquinolínico activo por vía oral, desarrollado por el Walter Reed Army Institute en colaboración con la empresa farmacéutica GlaxoSmithKline (Yeates, 2002), inicialmente pensado para combatir la malaria. Debido a que estudios preliminares en animales habían obtenido buenos resultados ante la LV, se llevaron a cabo ensayos clínicos, los cuales finalmente no demostraron una buena eficacia en tratamientos durante 28 días (Dietze y col., 2001).
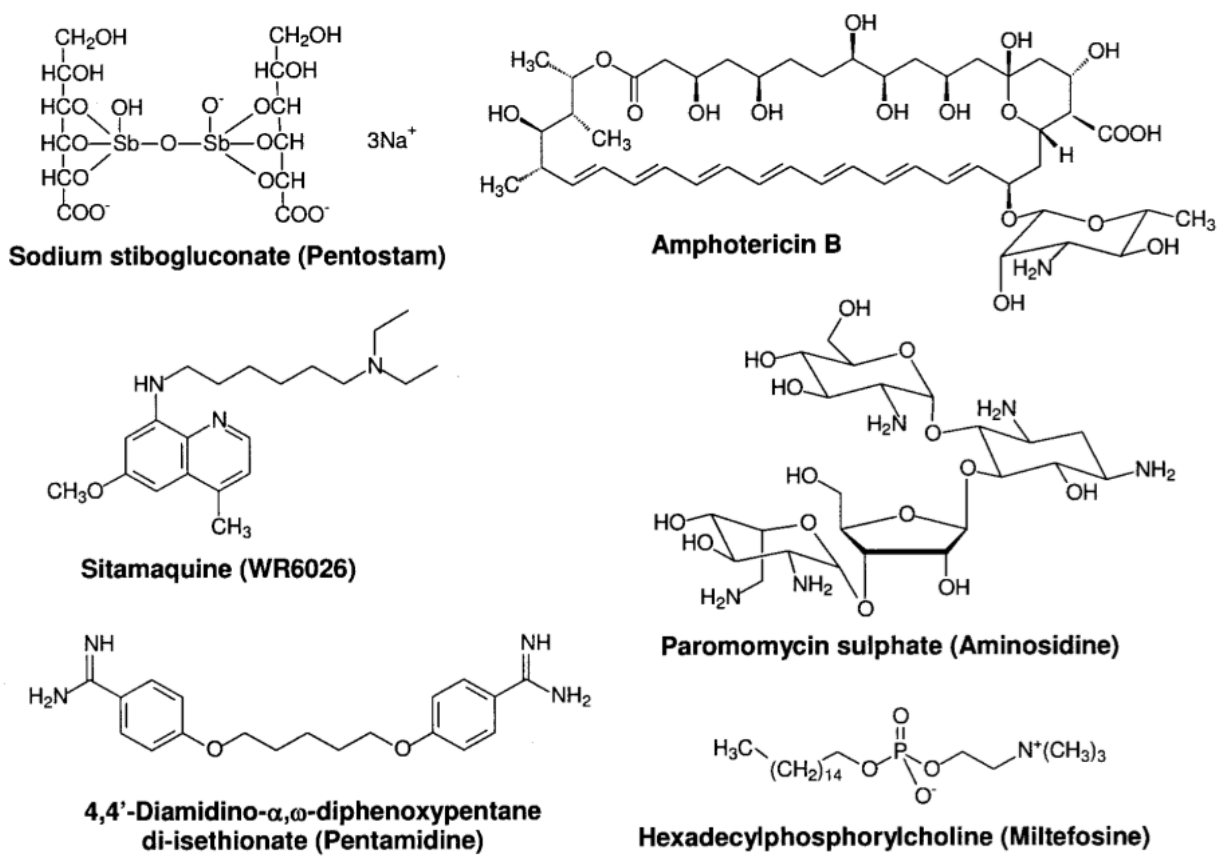

Figura 1.28. Fármacos empleados en el tratamiento de la leishmaniosis (Croft y col., 2006).

Con el fin de combatir la aparición de resistencias de la monoterapia, la combinación de fármacos para tratar la LV puede ampliar el espectro de actuación de las drogas, aumentar la actividad de las mismas mediante métodos aditivos o sinérgicos, disminuir la duración y las dosis, los efectos secundarios y el coste del tratamiento (Mohapatra, 2014). Por ejemplo, recientemente un estudio llevado a cabo en África comparó el tratamiento con paromomicina $(20 \mathrm{mg} / \mathrm{Kg} /$ día durante 21 días) o estibogluconato de sodio (30 mg/Kg durante 30 días), con la combinación de ambos $(15 \mathrm{mg} / \mathrm{Kg} /$ día de paromomicina y $20 \mathrm{mg} / \mathrm{Kg} /$ día de estibogluconato de sodio durante 17 días); la combinación de los dos fármacos durante 17 días fue igual de eficaz y seguro que los 30 días por separado (Musa y col., 2012). Desde el año 2011 se ha iniciado un ensayo de fase III que observará la seguridad y la eficacia del tratamiento con miltefosina, miltefosina en combinación con anfotericina B liposomal o estibogluconato de sodio en combinación con anfotericina B liposomal en pacientes de LV en África (Omollo y col., 2011).

\subsubsection{Nuevas dianas terapéuticas}

A pesar de todos los esfuerzos llevados a cabo en los tratamientos quimioterapéuticos para los distintos tipos de leishmaniosis, todos los fármacos englobados en este grupo presentan limitaciones como su precio, su seguridad, la 
eficacia, su toxicidad, los efectos secundarios y la aparición de resistencias. Por ello se intenta evitar la monoterapia y sustituirla por un tratamiento combinado como es el caso de la anfotericina B liposomal junto con la miltefosina, la paromomicina y la anfotericina B liposomal o la paromomicina y los antimoniales pentavalentes, en la India y en otras partes del mundo. Cabe destacar que la leishmaniosis es la única enfermedad tropical tratada por fármacos que no han sido diseñados específicamente contra el parásito Leishmania. Por ello y debido a la ausencia de una vacuna eficaz y de antígenos o inmunógenos potenciales, la identificación de nuevas dianas terapéuticas de rutas bioquímicas o metabólicas aparece como la mejor opción en la actualidad.

Algunas de estas dianas metabólicas son las enzimas de la biosíntesis de poliaminas, peptidasas, enzimas de la maquinaria glicosómica, del metabolismo de los tioles, quinasas dependientes de ciclinas, proteínas de la biosíntesis de esterol, quinasas activadas por mitógenos (MAPK), la dihidrofolato reductasa, las metacaspasas o las topoisomerasas. Las poliaminas no sólo promueven el crecimiento del parásito y su diferenciación, sino que también regulan la peroxidación lipídica generada por las ROs y facilitan su supervivencia en condiciones de estrés. En Leishmania, la arginina es convertida a L-ornitina por la enzima arginasa; la L-ornitina es descarboxilada a putrescina por la ornitina descarboxilasa, y más adelante transformada en espermidina y espermina, moléculas responsables de la muerte celular y la proliferación de los parásitos, al igual que de la respuesta inmune Th2 necesaria para la supervivencia de los patógenos en el hospedador definitivo (Balaña-Fouce y col., 2012a). Hazra y colaboradores (2013), evaluaron un derivado de la diospirina (D17), como un agente inhibidor de la ornitina descarboxilasa de L. donovani in vitro e in vivo. El tratamiento experimental de ratones BALB/c infectados con L. donovani con una dosis de $2 \mathrm{mg} / \mathrm{Kg}$ del compuesto redujo la carga parasitaria del hígado al 38\%; además, estudios de docking establecieron la inhibición no competitiva de la ornitina descarboxilasa de Leishmania por el D17.

Los inhibidores de peptidasas han sido empleados con éxito en el tratamiento de distintas enfermedades, entre ellas el SIDA, la hipertensión, la pancreatitis o el mieloma múltiple. En el genoma de L. major se han encontrado un total de 154 peptidasas; las más estudiadas han sido las cisteín peptidasas, formadas por las peptidasas tipo catepsina L (CPA y CPB), y las de tipo B (CPC). Las únicas que parecen esenciales para la supervivencia de Leishmania son las CPB, las cuales se han descrito como factores de virulencia en L. mexicana (Mottram y Coombs, 1998). Los genes que codifican para las CPB de L. mexicana están agrupados en tándem, y de entre ellos el gen CPB2.8 se ha descrito como el involucrado en aspectos de la patogenicidad de los parásitos. Schröder y colaboradores (2013), evaluaron una librería de compuestos potenciales contra la CPB 2.8 de L. mexicana mediante estudios de alto rendimiento (High Throughput Screening, HTS), e identificaron tres inhibidores nuevos de la enzima, los semicarbazones, tiosemicarbazones y los nitrilos de triazina.

Otra proteína básica en la supervivencia de los parásitos es la dihidrofolato reductasa (DHFR), la cual reduce el dihidrofolato a tetrahidrofolato utilizando NADPH como cofactor; está involucrada en la producción de timidina y, por tanto, un inhibidor de la enzima bloquearía la síntesis de ADN. Esta enzima fue 
cristalizada en L. major y T. cruzi, lo que puede ser aprovechado para comparar la estructuras con las de la enzima humana y diseñar drogas específicas (Liang y Anderson, 1998; Senkovich y col., 2009). Actualmente se está intentando buscar inhibidores de la DHFR en combinación con inhibidores de la proteína pteridín reductasa (PTR1). La PTR1 está involucrada en la reducción de biopterina a dihidrobiopterina y tetrahidrobiopterina, pero también es capaz de reducir dihidrofolato a tetrahidrofolato. Corona y colaboradores (2012), optimizaron un método por el cual eran capaces de obtener derivados de inhibidores de la PTR1 basándose en la estructura del compuesto. Cuando las moléculas inhibidoras seleccionadas fueron testadas junto con la pirimetamina, un inhibidor de la DHFR, observaron un efecto sinérgico en uno de ellos.

Por último cabe destacar la importancia de las ADN topoisomerasas como dianas terapéuticas en el tratamiento de la leishmaniosis y por su papel en el presente trabajo. Las ADN topoisomerasas son enzimas necesarias para eliminar el estrés de torsión y la tensión generada en el ADN al introducir cortes en la doble hélice, bien en una de las hebras (tipo I) o en las dos (tipo II). Las topoisomerasas son las dianas principales en cáncer y en la quimioterapia contra enfermedades causadas por bacterias (Schneider y col., 1990; Heisig, 2001), y la topoisomerasa IB (TopIB) ha sido identificada como una diana potencial contra Leishmania y otros tripanosomatidos (Bakshi y Shapiro, 2003; Balaña-Fouce y col., 2006; BalañaFouce y col., 2008), al ser una proteína esencial en la replicación del ADN, la recombinación y los mecanismos de reparación. La elección de la TopIB se basa en dos razones principales: i) la enzima tiene una expresión constitutiva y creciente a lo largo del ciclo de vida del parásito, de forma similar a las células tumorales y, principalmente, ii) debido a que la enzima de Leishmania posee una estructura diferente a la del hospedador definitivo (Villa y col., 2003).

Nuestro grupo descubrió que, a diferencia de la enzima monomérica humana, la TopIB de L. donovani estaba formada por dos subunidades diferentes, cada una codificada por genes distintos, las cuales debían ensamblarse en el parásito para reconstituir la enzima activa. Una de las subunidades contiene cuatro aminoácidos del centro activo, los cuales están muy conservados desde un punto de vista filogenético. La otra subunidad contiene el aminoácido catalítico (Tyr222), el cual es el encargado de cortar una de las hebras del ADN en una secuencia nucleotídica específica (Díaz-González y col., 2008). La TopIB de Leishmania posee dos regiones no conservadas, una en el extremo C-terminal del protómero mayor y la otra en el extremo N-terminal del protómero de menor tamaño, la cual determina la sensibilidad a los distintos tipos de venenos contra la enzima (Díaz-González y col., 2007). 


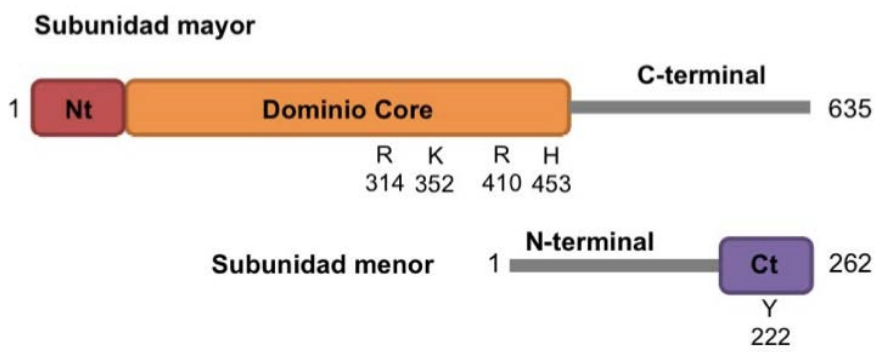

Figura 1.29. Representación esquemática de la TopIB de L. donovani. Nt se refiere al dominio Nterminal y $\mathrm{Ct}$ al dominio C-terminal. Los aminoácidos señalados constituyen los residuos del centro activo y la Tyr222 catalítica.

Las drogas desarrolladas contra la TopIB actúan i) interfiriendo con las propiedades catalíticas de la enzima (inhibidores), o ii) estabilizando los complejos ADN-enzima (venenos). Los venenos de la ADN topoisomerasa evitan el paso de religación y finalmente producen un corte en una de las hebras del ADN al colisionar con el anillo de replicación durante la síntesis del ADN (Pommier, 2006). El veneno más estudiado es la camptotecina (CPT) y sus derivados, entre ellos, el topotecan (Hycantim), el profármaco irinotecan (Camptosar) o su metabolito activo SN-38, los cuales han sido empleados contra ciertos tumores (Teicher, 2008).

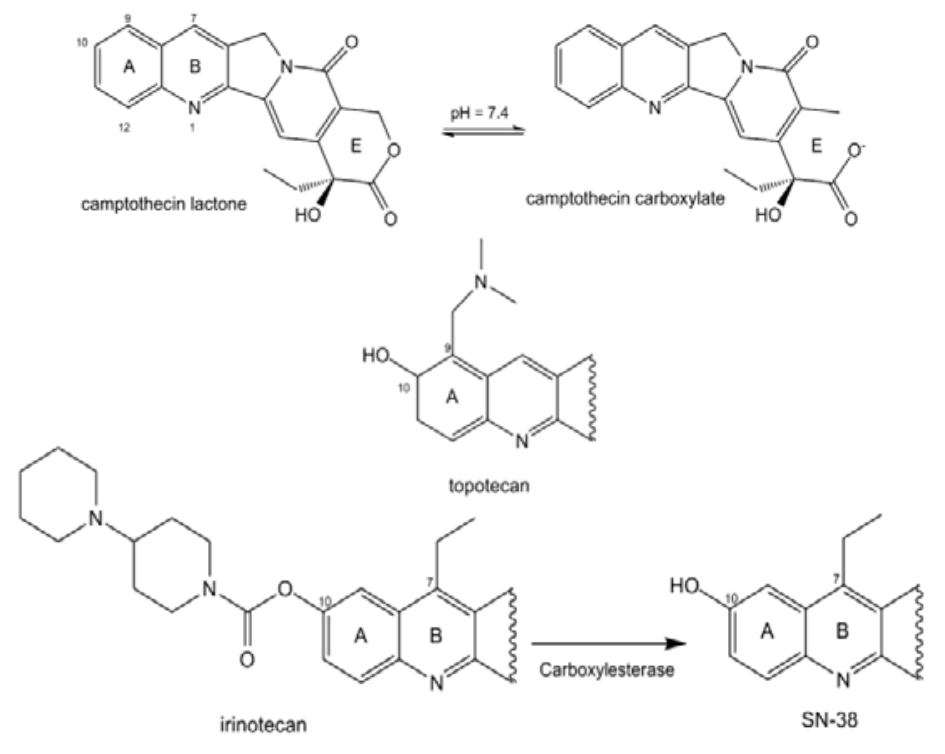

Figura 1.30. Estructuras químicas de los venenos de la TopIB de Leishmania, la CPT y sus derivados topotecan, el profármaco irinotecan y su metabolito activo SN-38 (Prada y col., 2013).

Otros compuestos que actúan como venenos de la TopIB y no son derivados de la CPT son los indolcarbazoles (como la droga intercalante rebecamicina), o las indenoisoquinolinas, desarrolladas inicialmente como antitumorales con una capacidad importante para estabilizar los complejos de corte de la enzima y el ADN (Antony y col., 2007; Prudhomme y col., 2003). Estudios llevados a cabo por 
nuestro grupo de investigación establecieron el potencial terapeútico de dos nuevas indenoisoquinolinas, el indotecan (LMP400) y el AM13-55, en el tratamiento de la LV; para ello se infectaron ratones BALB/c susceptibles a la infección por L. infantum, los cuales recibieron una dosis de $2.5 \mathrm{mg} / \mathrm{Kg}$ de indotecan o AM13-55 cada dos días durante dos semanas. La reducción de la carga parasitaria en el bazo y el hígado para el indotecan fue del $80 \%$, mientras que en el caso del AM13-55 tan sólo se redujo en el bazo (70-90\%), incluso doblando la dosis a $5 \mathrm{mg} / \mathrm{Kg}$; la resistencia de los parásitos del hígado puede ser debida a transformaciones metabólicas del compuesto a productos intermediarios inactivos (Balaña-Fouce y col., 2012b).

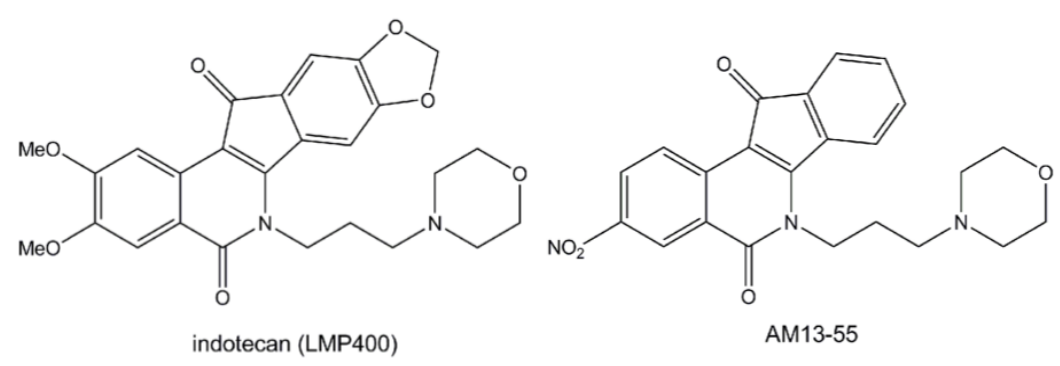

Figura 1.31. Estructuras químicas de los inhibidores indenoisoquinolínicos de la TopIB de Leishmania indotecan (LMP400) y AM13-55 (Balaña-Fouce y col., 2012b).

\subsubsection{Co-infección LV y VIH}

Los pacientes co-infectados de leishmaniosis visceral y el virus VIH presentan formas atípicas de la enfermedad y las recaídas son frecuentes. La presencia del virus en el organismo infectado con Leishmania dificulta la respuesta al tratamiento, especialmente en los pacientes que poseen un número de linfocitos inferior a 200 células/mL. Debido a los escasos ensayos clínicos llevados a cabo y al hecho de que los que se han realizado han involucrado únicamente infecciones causadas por L. infantum, existen actualmente muchas preguntas sin respuesta en cuando a la droga a emplear, la dosis, la duración del tratamiento, la profilaxis o la eficacia de la terapia combinada en estas personas (Monge-Maillo y López-Vélez, 2013). En Etiopía se hizo un ensayo clínico al azar en el que se comparó la eficacia de la miltefosina (100 mg/día durante 28 días) y el estibogluconato de sodio (20 $\mathrm{mg} / \mathrm{Kg} /$ día durante 30 días), en una población con una alta prevalencia de VIH; los autores concluyeron que la miltefosina oral fue más segura pero menos efectiva que el antimonio pentavalente en los pacientes co-infectados (Ritmeijer K. y col., 2006). Dos ensayos clínicos europeos compararon el antimonio con la anfotericina B y con la anfotericina B liposomal, obteniendo porcentajes de respuesta al tratamiento de 65,9 y $37 \%$ para los antimoniales pentavalentes, respectivamente (Laguna y col., 1999 y 2003). Sinha y colaboradores (2011), realizaron un estudio en la India empleando la anfotericina B liposomal a dosis de $20-25 \mathrm{mg} / \mathrm{Kg}$ durante 4-15 días; al principio todos los pacientes respondieron al tratamiento con una cura final del $85 \%$ después de 1 o 2 años del final del mismo. Por otra parte, la eficacia de la pentamidina o de la paromomicina no se ha establecido aún, al menos en regímenes del fármaco por separado. Muchos expertos están a favor de la 
terapia combinada en pacientes con recaídas múltiples (Alvar y col., 2008). Existen datos de un paciente seropositivo co-infectado con LV en Italia que fue tratado con una combinación de anfotericina $B$ liposomal $(4 \mathrm{mg} / \mathrm{Kg} /$ día durante 5 días consecutivos y durante los días $10,14,17,31$ y 38) y el factor de crecimiento humano recombinante junto con el factor estimulante de colonias de granulocito/monocito (rHuGM-CSF, $150 \mu \mathrm{g}$ por vía subcutánea, 2 veces a la semana durante 12 semanas). No se observaron efectos secundarios y tras dos años de seguimiento el paciente seguía curado de la enfermedad (Mastroianni, 2004).

\subsubsection{Vacunas contra la leishmaniosis}

La vacunación es la estrategia más económica y efectiva de controlar las enfermedades infecciosas. Una posibilidad para combatir las distintas formas de leishmaniosis es el desarrollo de vacunas que actúen tanto de forma terapéutica como profiláctica. Aunque no existe en la actualidad una vacuna humana en el mercado, distintos estudios que han empleado parásitos muertos o vivos o la combinación de distintos antígenos del parásito o de la saliva del vector invertebrado, con o sin adyuvantes, han demostrado cierto grado de eficacia en los ensayos de inmunización. El hecho de que la leishmaniosis es un complejo de enfermedades causadas por distintas especies de Leishmania, análisis genómicos indican la existencia de un alto grado de homología entre especies, lo que sugiere que la generación de una vacuna eficaz es posible (Kumar y Engwerda, 2014). Además, debido al fallo de los tratamientos actuales en referencia a su efectividad, precio, los efectos tóxicos secundarios y las vías no demasiado cómodas de administración junto con la aparición de resistencias, la obtención de una vacuna para controlar la leishmaniosis aparece como la mejor alternativa disponible hoy en día. Algunas de las formas de leishmaniosis se caracterizan por un estado de inmunidad parcial seguido de la resolución completa de la enfermedad, lo que indica que la inducción de la inmunidad protectora es posible.

La adquisición de una inmunidad protectora ante la infección con Leishmania spp. requiere el desarrollo de una respuesta inmune Th1 dependiente de IL-12 y caracterizada por la producción de IFN- $\gamma$ y TNF- $\alpha$ por las células T CD4+. Estas citoquinas proinflamatorias son necesarias para la generación de ROs y óxido nítrico por los macrófagos infectados lo que resulta en la eliminación de los parásitos intracelulares (Reed y col., 2003). Estudios recientes han descubierto que la IL-10 producida por las células T CD4+ es un inhibidor de la producción de IFN- $\gamma$ y promueve la persistencia de los parásitos en el bazo de los pacientes aquejados de LV (Gautam y col., 2011).

El proceso de "leishmanización" mediante el cual se inducía la infección local al inocular parásitos vivos de lesiones activas fue empleado de manera satisfactoria en la antigua Unión Soviética, Oriente Medio o Israel (Khamesipour y col., 2005); esta práctica se abandonó en la mayor parte de los países debido a problemas logísticos y de seguridad, ya que muchos individuos desarrollaron lesiones que no se curaban e inmunosupresión (Nadim y col., 1983).

El siguiente paso fue el empleo de parásitos muertos, ya en las primeras décadas del siglo XX. Convit y colaboradores (2004), desarrollaron una vacuna que contenía promastigotes muertos de Leishmania junto con el bacillo de la 
tuberculosis como coadyuvante (bacilo Calmette-Guerin, BCG), con la que trataron a 11532 pacientes infectados de CL en Venezuela, de los cuales evaluaron 5341 al azar y pertenecientes a distintas zonas geográficas. Las tasas de curación tuvieron una media del $18-78 \%$ y las reacciones adversas fueron muy leves. Sin embargo, los resultados del empleo de parásitos muertos son inconsistentes entre sí y las comparaciones imposibles debido a las grandes diferencias en la producción de las vacunas, las distintas especies parasitarias utilizadas y los protocolos empleados. Además, ninguno de los métodos empleados en la fabricación de estas vacunas de primera generación incluyen la ausencia de componentes bovinos en el medio de cultivo, procedentes del bacilo de la tuberculosis Mycobacterium bovis.

Por otra parte, el empleo de parásitos atenuados ha sido evaluado en distintos modelos animales. Estos parásitos son reconocidos por las células del huésped de la misma manera que las cepas virulentas y persisten durante cierto tiempo sin replicarse, tiempo que el hospedador emplea para crear una respuesta inmune fuerte y potente contra la infección. El grupo de Nakashi empleó una cepa de $L$. donovani que poseía una tasa de replicación intracelular deficiente para inducir inmunidad contra la LV. Dicha cepa poseía un defecto en su replicación como amastigotes tanto in vitro como ex vivo en macrófagos humanos debido a una deleción en el gen centrin1 que codifica para una proteína involucrada en la división celular de parásitos como Leishmania, Trypanosoma o Plasmodium (Selvapandiyan y col., 2009). Su seguridad fue demostrada por la ausencia de parásitos en el bazo y el hígado de ratones BALB/c susceptibles, ratones SCID inmunocomprometidos y hámsteres tras 10 semanas de infección. La inmunización con dicha cepa LdCen $1^{(-/)}$protegió a los animales desafiados incluso después de 16 semanas de la "vacunación"; además, esta inmunidad fue adquirida también por ratones infectados con L. braziliensis, agente causante de la LMC. Existen otros ejemplos de cepas en las que se han realizado deleciones génicas que han resultado en el desarrollo de cepas atenuadas de Leishmania. Entre las vacunas candidatas para tratar la LC, destaca la propuesta por el grupo de Grimaldi Jr, los cuales emplearon una cepa de L. major deficiente en el gen de la dihidrofolato reductasa timidilato sintasa $\left(d h f r-t s^{-}\right)$que protegía a ratones BALB/c pero no a monos Rhesus (Amaral y col., 2002).

Otra cepa modificada de L. major deficiente en el gen lipofosfoglicano (lpg) era incapaz de sobrevivir en el vector invertebrado y en el interior de los macrófagos pero mantenía la habilidad de persistir en el ratón de forma indefinida y de proteger ante los desafíos con una cepa virulenta de L. major, incluso en ausencia de una respuesta fuerte Th1 (Späth y col., 2003; Uzonna y col., 2004). Sin embargo, con el paso del tiempo este parásito recuperó de forma inesperada su virulencia (Späth y col., 2004). Por otro lado, una cepa de L. mexicana deficiente en los genes que codifican para las cisteín proteinasas $(\Delta c p a$ y $\Delta c p b)$, confería resistencia a ratones y hámsteres contra infecciones homólogas (Alexander y col., 1998; Saravia y col., 2006). En cuanto a los intentos por obtener cepas delecionadas como vacunas potenciales contra la $\mathrm{LV}$, destacan los estudios de inmunización realizados con una cepa de L. donovani deficiente para el gen del transportador de biopterina (BT1) (Papadopoulou y col., 2002). Las deleciones incompletas de genes pueden resultar en la reaparición de la virulencia de la cepa y, por tanto, la imposibilidad de su uso como vacuna segura al persistir el riesgo de reactivación de la enfermedad. 
Otras aproximaciones incluyen la combinación de distintos antígenos, con o sin adyuvantes, que induzcan la respuesta inmune en el hospedador, llamadas vacunas por "subunidades" (Coler y Reed, 2005). A diferencia de otros organismos patógenos, muchos de estos antígenos están muy conservados entre las distintas especies y aislados de Leishmania y, además, la variación antigénica no aparece como un problema determinante en estos parásitos. Coler y colaboradores (2007), evaluaron la eficacia de la vacuna recombinante Leish-111f formada por tres proteínas del parásito, un antioxidante específico de tiol (TSA), la proteína inducible por estrés de L. major (LmSTI1) y el factor de iniciación de la elongación de L. braziliensis (LeIF), los cuales habían demostrado por separado ser eficaces contra la LC y LMC en ratones, primates no humanos y humanos. Este grupo evaluó la respuesta inmune y la protección inducida por Leish-111f formulada con una emulsión estable del lípido A (Leish-111f MPL-SE) en ratones y hámsteres infectados con L. infantum; la inmunización con la vacuna provocó reducciones de la carga parasitaria del 99,6\%, junto con una respuesta inmune aumentada Th1. Es la primera vacuna que progresa a estudios clínicos de fase I y II en voluntarios sanos en América del Sur, pacientes de LC y LV en Brasil y Perú y pacientes curados de LV en la India (Nascimento y col., 2010; Chakravarty y col., 2011).

Por último, se encuentran las vacunas de ADN para prevenir los distintos tipos de leishmaniosis, las cuales cuentan con ciertas ventajas como los bajos costes de producción, su estabilidad, la expresión de uno o varios antígenos en la misma construcción o la generación de una respuesta inmune efectora y de memoria eficaz (Donnelly y col., 1997).

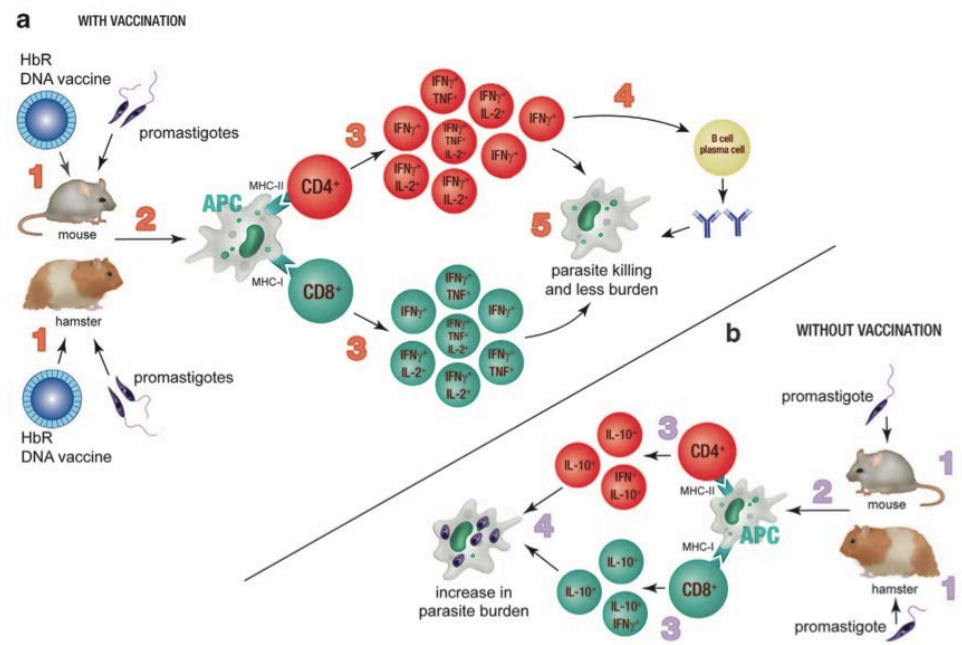

Figura 1.32. Representación esquemática de la vacunación con el ADN del receptor de hemoglobina de Leishmania (HbR). A) Ratones BALB/c y hámsteres fueron inmunizados y posteriormente infectados con L. donovani. Los parásitos fueron completamente eliminados gracias a la respuesta celular de las células T CD4+ y CD8+ y los anticuerpos producidos por las células B.

B) En ausencia de vacunación previa a la infección, la proliferación limitada de las células T y la liberación de IL-10 llevó a la persistencia y la supervivencia de los parásitos intracelulares (Kumar y Engwerda, 2014). 
Recientemente se ha descrito el empleo del ADN del receptor de hemoglobina de Leishmania (HbR) como posible vacuna para tratar la LV (Guha y col., 2013). Leishmania spp. requiere el grupo hemo para distintas actividades metabólicas pero estos parásitos son incapaces de sintetizarlo de forma endógena, por lo que son dependientes del producido por el hospedador. Este receptor está conservado entre distintas cepas del parásito y el anticuerpo anti-HbR se ha detectado en pacientes enfermos de kala-azar. La inmunización de ratones BALB/c y hámsteres con el ADN codificante del receptor $\mathrm{HbR}$ protegió contra la infección con $L$. donovani, además de estimular una respuesta inmune de células $\mathrm{T}$ mediante la producción de IL-12, IFN- $\gamma$ y TNF- $\alpha$ junto con una regulación negativa de las citoquinas Th2 IL-10 e IL-4. Sin embargo, y a pesar del potencial de las vacunas de ADN, aún no han sido testadas en el ser humano y tampoco existen ensayos clínicos que hayan pasado la fase II en humanos.

\subsection{LA BIOFOTÓNICA EN EL ESTUDIO DE LA LEISHMANIOSIS}

Durante la última década ha tenido lugar una revolución científica capitaneada por el empleo de parásitos que expresan proteínas fluorescentes o bioluminiscentes, en inmunología, en interacciones parásito-hospedador, en el testado masivo de nuevos fármacos o HTS (High-Throughput Screening), o en estudios in vivo de imagen a tiempo real de la patogénesis y de las terapias potenciales contra la enfermedades causadas por tripanosomátidos (Saeij y col., 2005; Franke-Fayard y col., 2006). Los distintos tipos de leishmaniosis no han sido una excepción, sino que el empleo de la biofotónica en modelos in vitro, ex vivo e in vivo en pequeños animales es actualmente uno de los pilares en el desarrollo y el descubrimiento de nuevos fármacos y vacunas potenciales contra estas enfermedades parasitarias. Finalmente, el empleo de cepas fluorescentes en combinación con potentes análisis genómicos ha llevado al descubrimiento de procesos de intercambio genético en tripanosomátidos.

Debido al papel crítico de las proteínas fluorescentes en el presente trabajo, más adelante se describirá su evolución desde el descubrimiento de la proteína fluorescente verde (GFP), hasta la aparición de las distintas variantes de la misma y las proteínas rojas e infrarrojas, siendo éstas últimas la nueva generación de reporteros fluorescentes en la actualidad.

\subsubsection{Reporteros fluorescentes vs. bioluminiscentes}

Los genes reporteros codifican un producto génico que permite obtener un fenotipo cuantificable y fácilmente distinguible sobre el fondo celular endógeno (Dube y col., 2009). En función de su aplicación, un gen reportero ideal debería:

* Estar ausente en la célula original.

* Ser inerte y no afectar la fisiología de la célula del parásito.

* Representar un método simple, sensible y barato para cuantificar la expresión del reportero. 
La gran utilidad de los parásitos modificados genéticamente que expresan reporteros fluorescentes o bioluminiscentes se ha puesto de manifiesto en las distintas áreas del estudio de las enfermedades parasitarias. Por ejemplo, ha mejorado notablemente técnicas clásicas como los métodos de tinción y contaje microscópico, los cuales son lentos y requieren de un gran trabajo por parte del investigador. Sin embargo, el empleo de proteínas fluorescentes ha experimentado un incremento exponencial a expensas de la bioluminiscencia, la cual ha sufrido un estancamiento en los últimos años.

El gen de la luciferasa ha sido clonado principalmente de la luciérnaga (Photinus pyralis), y el pensamiento de mar (Renilla reniformis) (Bronstein y col., 1994). La bioluminiscencia posee restricciones en comparación con las proteínas fluorescentes; la luciferasa cataliza la oxidación de la luciferina en presencia de iones $\mathrm{Mg}^{2+}$ y ATP a oxiluciferina, produciendo una ráfaga de luz de corta duración (hasta 30 minutos para la luciferasa de P. pyralis y 10 minutos para la de $R$. reniformis); por tanto, la bioluminiscencia requiere de la adición de un sustrato específico que debe ser captado por las células diana, y las placas o tejidos deben ser fijados y permeabilizados para obtener la señal, lo que unido a la corta vida media de la luz emitida una vez añadido el sustrato, hace imposible obtener medidas repetidas de la misma muestra. Por su parte, las proteínas fluorescentes emiten luz de forma intrínseca, y debido a que cubren casi la totalidad del espectro visible, permite seleccionar la mejor proteína para un experimento concreto, o una combinación de dos o más proteínas para estudios en los que se pretenda identificar distintos procesos o la interacción entre ellos (Shcherbakova y col., 2012). Cabe destacar, sin embargo, la superioridad de las proteínas bioluminiscentes en estudios in vivo con cepas viscerales de Leishmania debido a las propiedades ópticas de los propios tejidos (Lang y col., 2009).

\subsubsection{Generación de cepas modificadas de Leishmania que sobreexpresan genes fluorescentes o bioluminiscentes}

Para conseguir que las cepas sean completamente funcionales, los genes reporteros deben expresarse de forma constitutiva y a lo largo de todo el ciclo biológico del parásito. Además, aspectos como la virulencia, la resistencia a fármacos o la fisiología en general de los parásitos transgénicos deben permanecer intactos en comparación con las cepas salvajes. En este sentido, la transfección de los parásitos puede ser transitoria o estable; aunque es cierto que los vectores episomales poseen una tasa de replicación mayor, también favorece una expresión desigual debido a la alta variación del número de copias del mismo (Lang y col., 2009; Mißlitz y col., 2000; Roy y col., 2000); además, los vectores episomales requieren de la adición del antibiótico de selección de manera continua para evitar la pérdida del transgén. Por su parte, la integración del reportero en el genoma del parásito previene de la pérdida del mismo, lo que tiene una vital importancia en estudios en los que se requiere el pase de los parásitos por el vector mamífero para recuperar virulencia o en estudios de imagen in vivo en animales (Pulido y col., 2012; Mehta y col., 2008; Millington y col., 2010).

Muchos estudios han demostrado cómo la tasa de expresión del gen reportero bajo el promotor del ARN ribosómico 18S (ARNr), depende de la fase del ciclo del parásito; los amastigotes de L. amazonensis modificados para que expresaran el gen de la luciferasa en el ARNr 18S mostraban una expresión 10 veces menor 
comparada con la de los promastigotes (Lang y col., 2005). Las razones de esta regulación negativa en la fase intracelular parecen estar relacionadas con diferencias metabólicas entre las distintas fases del ciclo de vida del parásito, diferencias en la composición del medio de cultivo, el pH ácido de fagolisosoma en el interior de los macrófagos infectados o una inhibición por proteasas. También se ha estudiado el papel de las regiones no traducidas (UTRs) que flanquean los genes reporteros, ya que están involucradas en la regulación post-transcripcional de los mismos. Mißlitz y colaboradores mostraron que la que la expresión de la EGFP (Enhanced GFP) era de 2-10 veces mayor en amastigotes de L. mexicana y L. major que en promastigotes tras la inserción de la región 3' UTR del gen de la cisteína proteinasa B 2.8 (CPB 2.8) aguas abajo del gen fluorescente (Mißlitz y col., 2000). La generación de nuevos vectores debería incluir distintos fragmentos de regiones intergénicas de genes que se sobreexpresen en la fase amastigote; en este sentido, tecnologías como la secuenciación de ARN mensajeros (ARNm) pueden aportar información vital del transcriptoma del parásito (Rastrojo y col., 2012; Holzer y col., 2006).

\subsubsection{Evolución de las proteínas fluorescentes}

Ya han pasado más de dos décadas desde la clonación del gen de la proteína fluorescente verde (GFP) (Prasher y col., 1992), aislado del genoma de la medusa bioluminiscente Aequorea victoria, y 20 años desde la primera demostración de su utilidad como chivato fluorescente para monitorear la expresión génica o la localización de proteínas in vivo (Chalfie y col., 1994). Estos descubrimientos sentaron las bases del empleo de ésta y otras proteínas fluorescentes en casi la totalidad de los campos de la ciencia moderna. Por ello, los hombres que lo hicieron posible fueron merecedores del Premio Nobel de Química en el año 2008 "por el descubrimiento y el desarrollo de la proteína fluorescente verde, GFP", un premio compartido por los científicos Osamu Shimomura, Martin Chalfie y Roger Y. Tsien. El japonés Osamu Shimomura es el responsable del descubrimiento de la GFP en 1962 y de la descripción de los tres aminoácidos que conforman el cromóforo de la misma (Ser65-Tyr66-Gly67). En el verano de 1961, Shimomura y Frank Johnson en la Universidad de Princeton (Nueva Jersey, USA), purificaron una proteína bioluminiscente de la zona terminal del paraguas de la medusa a la que denominaron "aequorina", la cual al interaccionar con los iones de calcio presentes en el agua de mar emitía una luz azul y no verde (Shimomura y col., 1962).

En el artículo de 1962 ya mencionaban que habían aislado también una proteína que era verdosa a la luz del día, amarillenta bajo la luz de una bombilla y verde fluorescente bajo luz UV o luz azul; era la primera descripción de la GFP. La fluorescencia verde de la GFP tenía lugar cuando la aequorina interaccionaba con los iones calcio, generándose una luz azul, cuya energía era absorbida por el cromóforo de la proteína verde. En una segunda fase, tras la excitación del cromóforo, éste liberaba dicha energía y emitía luz en la zona verde del espectro (Morise y col., 1974). Por su parte, el americano Martin Chalfie empleó el gen de la proteína para expresarlo primero en la bacteria intestinal Escherichia coli y, más adelante, en neuronas del gusano eucariota Caenorhabditis elegans. La increíble aportación del norteamericano Roger Y. Tsien fue la generación de mutantes de la proteína nativa, los cuales absorbían y emitían luz en otras partes del espectro, apareciendo variantes tres colores distintos, azul, cian y amarillo. 

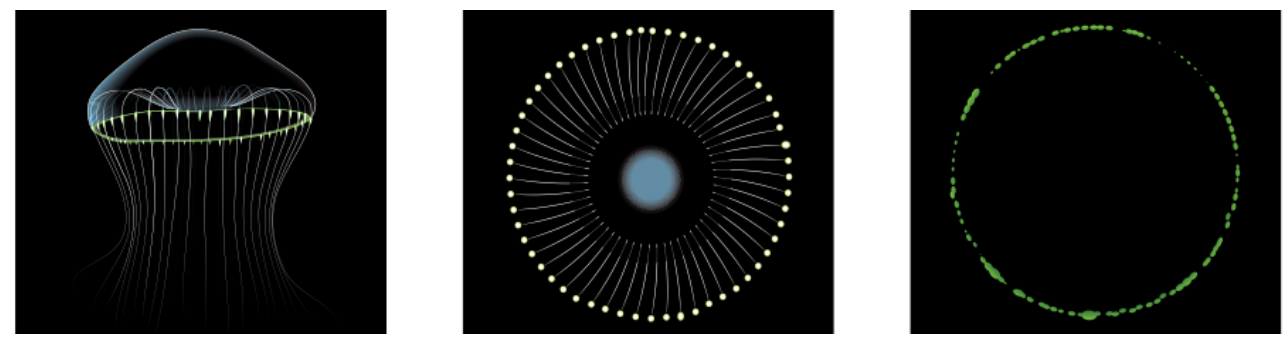

Figura 1.33. Imagen de la medusa Aequorea victoria y su órgano bioluminiscente localizado a lo largo de su "paraguas" (Premio Nobel de Química 2008).

Una de las claves del éxito de las proteínas fluorescentes es su capacidad de emitir luz por sí mimas, es decir, de no requerir cofactores como las proteínas bioluminiscentes, sino de ser autofluorescentes, con el único requisito de disponer de oxígeno molecular. La formación del cromóforo requiere de una reacción de ciclación seguida de una oxidación de los aminoácidos Ser65-Tyr66-Gly67, lo cual se produce de forma espontánea, tan sólo con la necesidad de oxígeno para que tenga lugar la modificación post-traduccional (Heim y col., 1994). Por tanto, simplemente la introducción de un fragmento de ADN adecuado en casi cualquier organismo lleva a la aparición de fluorescencia. Dado que la información necesaria para la aparición de la señal fluorescente se encuentra en la secuencia de ADN, dicha secuencia nucleotídica puede ser modificada, empleando técnicas básicas de biología molecular, para la obtención de proteínas recombinantes, fusionar estas proteínas fluorescentes a otras de interés o para la generación de organismos transgénicos. En este sentido, la introducción de sólo una mutación en la secuencia original de la GFP era suficiente para modificar las propiedades espectrales de la proteína, evidenciando que la fluorescencia dependía de la estructura proteica (Tsien, 1998). El cristal de la proteína se obtuvo en 1996 por el grupo de Roger Tsien y James Remington; la proteína fluorescente está formada por una sola cadena de 238 aminoácidos dispuestos en 11 láminas $\beta$ en forma de barril con una hélice coaxial, y el cromóforo situado en la hélice central.

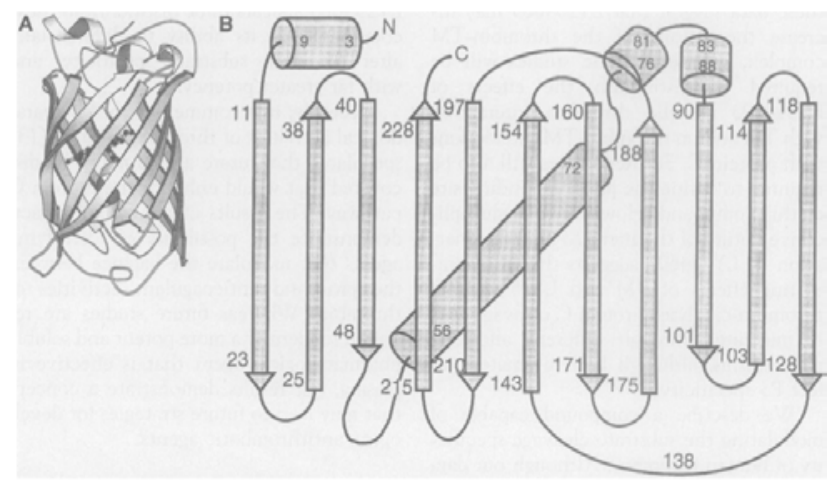

Figura 1.34. Dibujo esquemático de la estructura de la GFP con el cromóforo en el interior del barril (A) y las 11 láminas $\beta$ con el número aproximado de los aminoácidos que conforman la estructura secundaria de la proteína (B). N, extremo N-terminal; C, extremo C-terminal (Örmo y col., 1996). 
El primer mutante generado desplazaba las longitudes de onda de excitación y emisión hacia la zona azul del espectro, con tan sólo una mutación crítica en la Tyr66 del cromóforo a His, aunque con una intensidad de fluorescencia débil (Heim y col., 1994). En 1995 el mismo grupo publicó un artículo en el cual se mostraban variantes mejoradas de la GFP nativa, entre ellas una proteína fluorescente azul (BFP), más brillante que la primera y un primer mutante que poseía longitudes de onda desplazadas hacia la zona roja del espectro (Heim y col., 1995). Un año más tarde se describió una nueva proteína mutante con unas longitudes de onda de excitación y emisión significativamente desplazas hacia la zona roja del espectro, como resultado de la mutagénesis de tan sólo uno de los aminoácidos de la proteína original (Thr203 a Tyr o His) (Ormö y col., 1996).

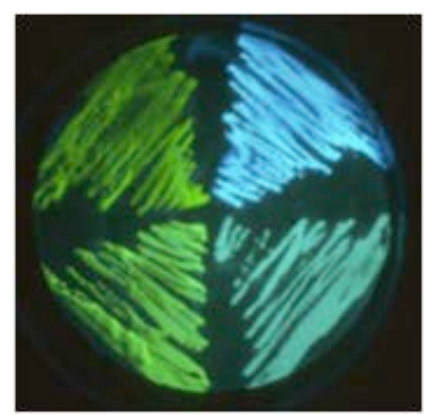

Figura 1.35. Bacterias de E. coli transformadas con distintos mutantes de la GFP nativa. En sentido horario desde el extremo superior derecho: mutante fluorescente azul o BFP (mutaciones Y66HY145F, Heim y Tsien, 1996); mutante cian o CFP (mutaciones Y66W-N146I-M153T-V163A-N212K,

Heim y Tsien, 1996); mutante verde o EGFP (Heim y col., 1995); y mutante amarillo o YFP (mutaciones S65G-V68L-S72A-T203Y, Ormö y col., 1996) (Zacharias y Tsien, 2006).

La disponibilidad de proteínas fluorescentes de distintos colores permite realizar experimentos de monitorización de al menos dos elementos diferentes, bien sean genes o proteínas, medir interacciones proteína-proteína mediante análisis FRET (Transmisión de Energía de Resonancia) al fusionar proteínas de interés con proteínas fluorescentes, estudiar la transducción de señales celulares, etc. Los mutantes amarillos de la GFP (YFP) generados presentaban una excesiva sensibilidad a cambios de $\mathrm{pH}$, además de dificultades en cuanto a su elevada sensibilidad a compuestos ácidos, su fotoestabilidad y su expresión a temperaturas de $37^{\circ} \mathrm{C}$.

Para solucionar estos problemas Griesbeck y colaboradores (2001), generaron una nueva proteína fluorescente amarilla que consistía en la GFP nativa con las siguientes mutaciones: S65G-V68L-Q69M-S72A-T203Y. El nuevo mutante recibió el nombre de Citrine reflejando su color amarillo y su resistencia ácida. La proteína mejorada poseía indiferencia a pHs ácidos, era dos veces más fotoestable que las otras YFPs y permitía su expresión a temperaturas fisiológicas y en distintos orgánulos, lo que evidenciaba un correcto plegamiento y conformación.

Sin embargo, y a pesar de lo publicado en el Science de 1996, el único color que Tsien no pudo generar a partir de la mutación de la secuencia original de la GFP fue el rojo. La luz roja tiene la capacidad de reducir el ruido de la autofluorescencia 
y penetrar los tejidos biológicos más fácilmente, por lo que es especialmente útil para experimentos en los que se busca el estudio de células y órganos en organismos vivos. Así es como entrarían en escena dos científicos rusos, Mikhail Matz y Sergei Lukyanov, los cuales identificaron seis proteínas fluorescentes homólogas a la GFP trabajando con distintas especies de Anthozoa, y de entre ellas una que emitía en longitudes de onda del rojo, drFP583, aislada del coral marino Discosoma striata. Estas proteínas fueron aisladas de organismos no bioluminiscentes ya que estos autores consideraban que la bioluminiscencia evolucionó de manera independiente y, relativamente reciente, en distintos grupos filogenéticos, por lo que las funciones o dominios ancestrales de las proteínas fluorescentes podían estar presentes también en estos organismos. La utilidad de las nuevas proteínas para el marcaje in vivo fue demostrada mediante ensayos de microinyección de ARN mensajeros (ARNm) en embriones de Xenopus (Matz y col., 1999).

Un año más tarde, el grupo de Tsien se haría con la proteína roja fluorescente drFP583 o DsRed, como ya se la conocía de forma comercial, para su caracterización bioquímica (Baird y col., 2000). Este trabajo estableció que la proteína de 28 kDa poseía un coeficiente de extinción mucho mayor (capacidad de absorción de luz a una determinada longitud de onda), un rendimiento cuántico más elevado (número de fotones de fluorescencia emitidos por cada fotón de excitación absorbido), una resistencia a $\mathrm{pH}$ extremos excelente y un fotoblanqueo muy favorable (destrucción de un fluoróforo excitado debido a la generación de ROs). Además, la única mutación de la Lys-83 a una Met se traducía en una mejora de la longitud de onda de emisión, que pasaba de $583 \mathrm{~nm}$ a $602 \mathrm{~nm}$. Sin embargo, la proteína contaba con importantes inconvenientes como el hecho de ser un tetrámero obligado in vitro y en células vivas, y su lenta maduración. Su empleo como marcador en gran cantidad de aplicaciones biológicas requeriría de la supresión de la tetramerización y la aceleración de su maduración.

En el año 2002, el mismo grupo de Roger Y. Tsien publicaría la dimerización y posterior monomerización de la proteína roja fluorescente DsRed, la cual recibiría el nombre de mRFP1 (Campbell y col., 2002). La estrategia que siguieron para reducir el estado de oligomerización fue la introducción de residuos de arginina en puntos clave de la interfaz de las subunidades, ya que la proximidad de cargas positivas destruiría la interacción entre ellas, además de la introducción de 17 mutaciones en el caso del dímero, y 33 en la mRFP1.

Esta aproximación ya se había empleado para eliminar la tendencia a dimerizar por parte de la GFP, todo ello sin alterar la maduración de la proteína o su intensidad de fluorescencia (Zacharias y col., 2002). Aunque la proteína mRFP1 tenía un coeficiente de extinción, un rendimiento cuántico y una fotoestabilidad algo menores que la originaria DsRed, el monómero maduraba 10 veces más rápido, por lo que mostraba una intensidad de fluorescencia similar en células vivas, y los picos de excitación y emisión estaban alejados $25 \mathrm{~nm}$ en el espectro visible, en comparación con la proteína DsRed. 

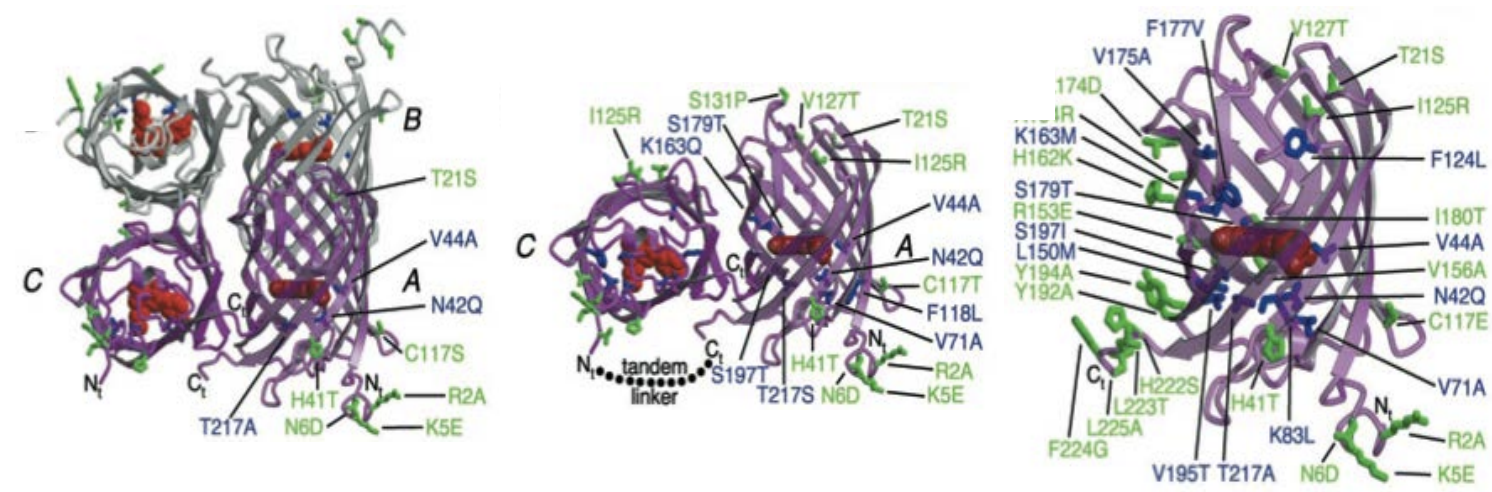

Figura 1.36. Representación gráfica del tetrámero de DsRed, el dímero y el monómero (mRFP1) a partir de la estructura del cristal de la proteína. Las posibles conformaciones de las subunidades aparecen representadas como A, B y C; el cromóforo aparece en rojo, los residuos externos en verde y los residuos internos en azul (Campbell y col., 2002).

A pesar de las mejoras obtenidas con la mRFP1, el grupo de Tsien continuó investigando cómo paliar y solucionar las propiedades menos ventajosas de la proteína y publicó la siguiente generación de monómeros fluorescentes (Shaner y col., 2004). La estrategia siguió siendo la de someter a la secuencia de la mRFP1 a distintas rondas de mutagénesis, lo que resultó en la obtención de variantes de nuevos colores, un aumento en la tolerancia a su fusión a otras proteínas por ambos extremos $\mathrm{N}$ - y C-terminales (mediante la inclusión de las secuencias de los extremos terminales de la GFP en las nuevas proteínas), y mejoras en los coeficientes de extinción, los rendimientos cuánticos y la fotoestabilidad.

Además se identificó la mutación Q66M como la responsable de promover una maduración completa de la proteína. A lo largo de las distintas rondas de mutagénesis, los mejores mutantes fueron seleccionados y caracterizados, recibiendo el nombre de distintas frutas como consecuencia de los colores fluorescentes de los mismos. Entre las nuevas proteínas se encontraban: mHoneydew, mBanana, mOrange, el dímero dTomato, el tándem tdTomato, mTangerine, mStrawberry y mCherry. La mayor intensidad de fluorescencia se encuentra en tdTomato, a costa de doblar su peso molecular; de entre los monómeros mCherry es la que ofrece las longitudes de onda más alejadas, una mayor fotoestabilidad, una tasa de maduración más rápida y una resistencia excelente a cambios de $\mathrm{pH}$; aunque su rendimiento cuántico es levemente menor que el de mRFP1, posee un coeficiente de extinción mucho mayor (debido a su completa maduración) y una tolerancia excelente a la fusión proteica en el extremo N-terminal.

En la actualidad existe una "paleta de color" que cubre prácticamente el espectro visible al completo (Shaner y col., 2005). Esto permite el empleo de varios fluorocromos a la vez o la selección de la proteína perfecta para un experimento concreto. Sin embargo, los estudios de fluorescencia en animales vivos siguen estando limitados por la pobre penetración de los tejidos de las proteínas fluorescentes disponibles. En este sentido las proteínas con longitudes de onda de excitación y emisión en la zona roja lejana o infrarroja del espectro, potenciarían la adquisición de imágenes a una mayor profundidad, las cuales están restringidas 
por una mayor dispersión y absorción de la luz, aunque con dependencia del tipo de tejido. Estos dos procesos ópticos determinan la "longitud de atenuación", la cual reduce las probabilidades de que un fotón se propague adecuadamente; así, a menor dispersión y absorción de la luz en el tejido biológico, la longitud de atenuación es mayor, como en el caso de la luz infrarroja (Lecoq y Schnitzer, 2011).
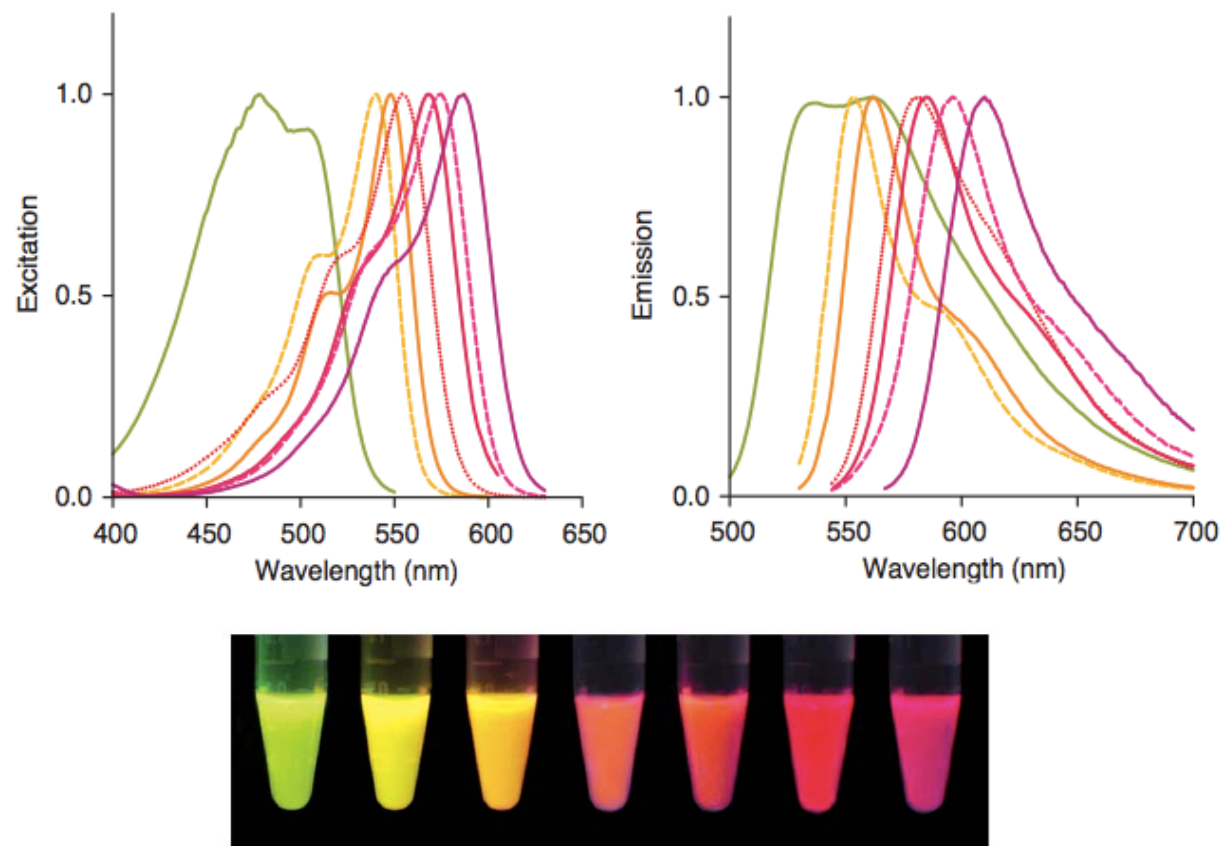

Figura 1.37. Caracterización de las nuevas variantes fluorescentes. Espectros de excitación y emisión de las distintas proteínas y extractos de las proteínas purificadas; de izquierda a derecha: mHoneydew, mBanana, mOrange, tdTomato, mTangerine, mStrawberry y mCherry (Shaner y col., 2004).

En el año 2004, Wang y colaboradores emplearon la hipermutación somática (SHM) utilizada por los linfocitos B para crear proteínas fluorescentes rojas con una fotoestabilidad mejorada y emisiones en el rojo lejano. Los linfocitos B del sistema inmune son capaces de mutar específicamente las inmunoglobulinas en respuesta a la interacción con antígenos. Este grupo demostró el empleo de la SHM para generar fenotipos útiles de un gen exógeno, que en su caso fue la mRFP1.2. Dos proteínas fluorescentes rojas fueron seleccionadas, mPlum $(\lambda e x=590 \mathrm{~nm}$, $\lambda$ em $=649 \mathrm{~nm})$ y mRaspberry $(\lambda e x=598 \mathrm{~nm}, \lambda e m=625 \mathrm{~nm})$. 

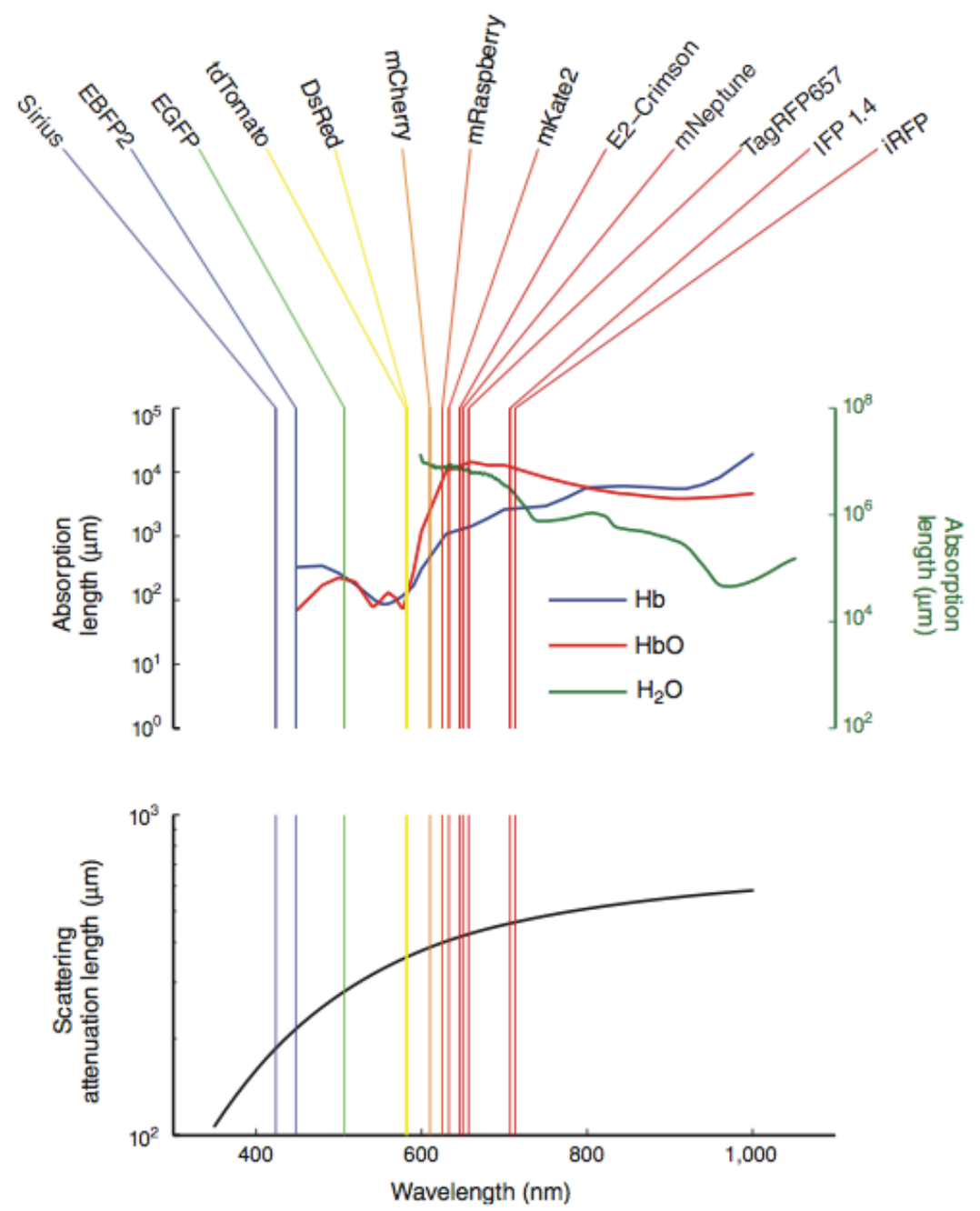

Figura 1.38. Longitudes de absorción y de dispersión de distintas proteínas fluorescentes. Las longitudes de atenuación son mayores para la luz infrarroja en comparación con la luz visible. También se muestran las longitudes de atenuación de la deoxihemoglobina (Hb, eje izquierdo), oxihemoglobina ( $\mathrm{HbO}$, eje izquierdo) y del agua (eje derecho). El panel inferior muestra la dependencia de la longitud de dispersión de la luz con la longitud de onda de una muestra de piel humana (Lecoq y Schnitzer, 2011).

Con la idea de mejorar los reporteros disponibles para el estudio de tejidos animales profundos por fluorescencia, otras dos proteínas fluorescentes con propiedades espectrales en el rojo lejano fueron descritas; Katushka $(\lambda \mathrm{ex}=588 \mathrm{~nm}$, $\lambda$ em=635 $\mathrm{nm}$ ), la cual era entre 7-10 veces más brillante que mPlum, poseía un tiempo de maduración más corto y una elevada estabilidad al $\mathrm{pH}$ y fotoestabilidad, y la versión monomérica mKate (Shcherbo y col., 2007). El mismo grupo publicaría dos años más tarde las versiones mejoradas de ambas proteínas, mKate2, probada en embriones de Xenopus laevis, y el tándem tdKatushka2, las cuales aparecían como la siguiente generación de proteínas fluorescentes en el rojo lejano para estudios en células vivas y en animales (Shcherbo y col., 2009 352).Sin embargo, ese mismo año el grupo de Roger Tsien publicaría la proteína fluorescente roja con las longitudes de onda más alejadas, Neptune, la primera proteína fluorescente con un pico de excitación en $600 \mathrm{~nm}(\lambda e x=600 \mathrm{~nm}, \lambda e m=650 \mathrm{~nm})$. En este caso coexpresaron las proteínas mKate o Neptune junto con la GFP en un vector 
monocistrónico de adenovirus, con el que transfectar células hepáticas HEK293A para obtener virus e infectar animales para estudios de imagen in vivo (Lin y col., 2009).
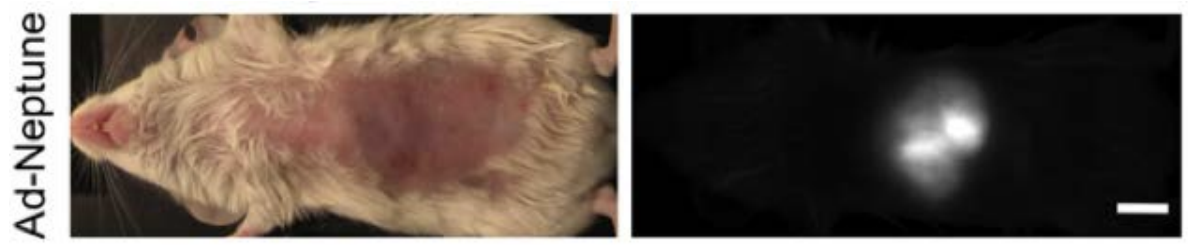

Figura 1.39. Imagen de epifluorescencia del hígado de un ratón infectado con adenovirus que expresaban la proteína fluorescente Neptune. Tras 5 días post-infección, los ratones fueron anestesiados, depilados y las imágenes tomadas en el sistema de imagen Maestro (Lin y col., 2009).

Como no podría haber sido de otra manera, fue el grupo de Tsien en el Instituto Médico Howard Hughes de la Universidad de California (San Diego, USA), el que continuaría abriendo camino en el descubrimiento y la generación de nuevas proteínas fluorescentes para estudios in vivo en animales. Una de las estrategias para tomar imágenes de tejidos profundos (más de unos pocos milímetros), ha sido el empleo de luz infrarroja. Esto se debe a que la hemoglobina, la cual absorbe luz visible, y el agua y los lípidos, los cuales absorben la luz infrarroja, tienen sus mínimos de absorción en la región comprendida entre los 650 y los $900 \mathrm{~nm}$. Además, la toma de imágenes en la región infrarroja tiene la ventaja añadida de minimizar la autofluorescencia de los tejidos y la dispersión de la luz, lo que puede mejorar notablemente el ratio señal/ruido (Weissleder y Ntziachristos, 2003). Sin embargo, hasta ese momento las longitudes de onda máximas no habían excedido los $611 \mathrm{~nm}$ de excitación para la proteína E2-Crimson (derivada de la proteína mejorada DsRed-Express2; Strack y col., 2009), y los 655 nm de emisión en el caso del mutante AQ143, aislado de la anémona de mar Actinia equina (Shkrob y col., 2005).

A diferencia de las proteínas fluorescentes "tipo GFP", longitudes de excitación y emisión de 644 y 672 nm, respectivamente, se habían observado en una proteína fluorescente basada en un fitocromo de una cianobacteria que incorporaba ficocianobilina como cromóforo (Fischer y Lagarias, 2004). Los fitocromos son receptores fotosensibles que absorben luz en la parte roja e infrarroja del espectro (Sharrock, 2008). Son homodiméricos y poseen tres dominios bien conservados, PAS, GAF y PHY, que conforman el dominio de unión al cromóforo (CBD). Este cromóforo es un tetrapirrol abierto como la biliverdina IX $\alpha$, la ficocianobilina o la fitocromobilina, unido covalentemente a uno de los dos primeros dominios. El empleo de bacteriofitocromos (BphPs) para el diseño de proteínas fluorescentes infrarrojas es más ventajoso ya que la biliverdina, que actúa como cofactor obligado de los mismos, es el intermediario inicial del metabolismo del grupo hemo en las células de mamíferos (Rockwell y col., 2010). 


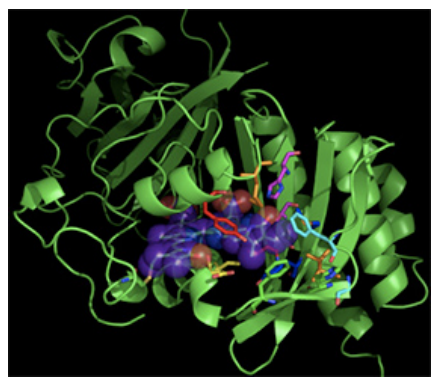

Figura 1.40. Estructura de un bacteriofitocromo con el anillo tetrapirrólico de la biliverdina en el centro y representado en azul (www.ucsdnews.ucsd.edu/archive).

Shu y colaboradores (2009), desarrollaron un bacteriofitocromo monomérico obtenido de la bacteria Deinococcus radiodurans capaz de incorporar espontáneamente biliverdina como cromóforo y de ser empleado como proteína infrarroja en células in vitro e in vivo en estudios de imagen a tiempo real. El bacteriofitocromo estaba formado por el dominio de unión al cromóforo (CBD) que contenía los domionios PAS y GAF necesarios y suficientes para la incorporación covalente de biliverdina; los 14 aminoácidos que rodeaban la biliverdina fueron identificados para las distintas rondas de mutagénesis. Se obtuvieron distintos mutantes, destacando las proteínas IFP $1.1(\lambda e x=686 \mathrm{~nm}, \lambda$ em=713 nm) y IFP 1.4 $(\lambda e x=684 \mathrm{~nm}, \lambda e m=708 \mathrm{~nm})$. La expresión de la proteína IFP 1.4 sin la adición de biliverdina generaba una fluorescencia infrarroja brillante y homogénea en la línea celular HEK293A además de permitir su fusión a otras proteínas. Igualmente, su expresión se comparó en hígados de ratones infectados con adenovirus que expresaban la proteína infrarroja IFP 1.1 y la GFP (Ad5I), y la proteína roja fluorescente mKate (Ad5K), tras la inyección o no de biliverdina. En el estudio se confirmó la mayor penetración de los tejidos por parte de la proteína infrarroja.

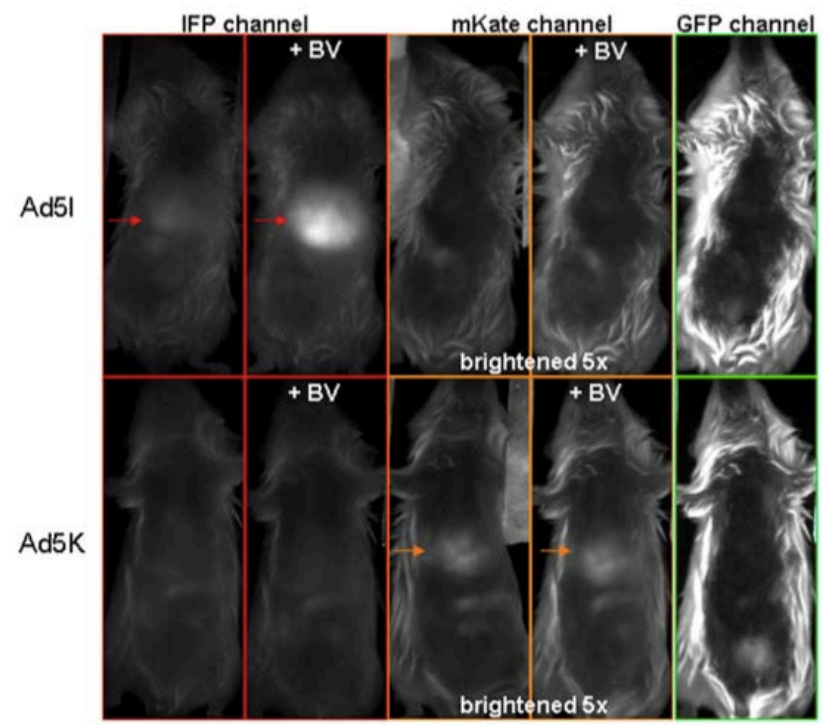

Figura 1.41. Imágenes de ratones infectados con los adenovirus Ad5I y Ad5K que sobreexpresan las proteínas IFP 1.1 y mKate, respectivamente. La adición de biliverdina permite visualizar los hígados infectados en el canal infrarrojo (Shu y col., 2009). 
Dos años más tarde el mismo grupo que había determinado la estructura y los aminoácidos clave en el funcionamiento del bacteriofitocromo de D. radiodurans, DrCBD (Wagner y col., 2008), desarrolló la proteína fluorescente infrarroja con las longitudes de onda más alejadas $(\lambda \mathrm{ex}=698 \mathrm{~nm}, \lambda \mathrm{em}=720 \mathrm{~nm})$, denominada Wi-Phy y basada en la sustitución de dos de los aminoácidos fundamentales (Auldridge y col., 2012).

La última generación de proteínas fluorescentes infrarrojas ha sido desarrollada por el grupo de Vladislav Verkusha a partir del bacteriofitocromo de la bacteria fotosintética Rhodopseudomonas palustris, RpBphP2 (Filonov y col., 2011). Tras distintas rondas de mutagénesis seleccionaron el mejor mutante, que recibió el nombre iRFP $(\lambda e x=690 \mathrm{~nm}, \lambda e m=713 \mathrm{~nm})$. Comparada con la proteína IFP 1.4, iRFP exhibía un coeficiente de extinción superior, un rendimiento cuántico algo menor y una intensidad de luz mayor. La estabilidad ante cambios de pH y el tiempo de maduración eran similares. A pesar de no presentar a priori diferencias demasiado marcadas entre las dos proteínas, la expresión de ambas proteínas en células HeLa demostró la superioridad en la intensidad de fluorescencia de iRFP incluso en ausencia de biliverdina; iRFP era 13 veces más brillante sin la adición de biliverdina y 7 veces más intenta tras la suplementación de la molécula en el cultivo. Además, mientras que para la proteína IFP 1.4, la adición de biliverdina debía mantenerse constante durante periodos de tiempo largos, la nueva proteína iRFP alcanzaba la intensidad de fluorescencia máxima sin requerir de la adición exógena de la molécula; esto apoyaba los resultados que demostraban la mayor afinidad de iRFP por la biliverdina, requiriendo concentraciones mucho más bajas de la biliverdina endógena producida por las propias células. Por último, los autores analizaron la aplicación de la proteína infrarroja en estudios de imagen in vivo en animales. Para ello infectaron ratones con adenovirus que expresaban ambas proteínas; la emisión de la iRFP in vivo fue 22 veces mayor sin la adición de biliverdina exógena y 7 veces mayor tras la inyección de la molécula.

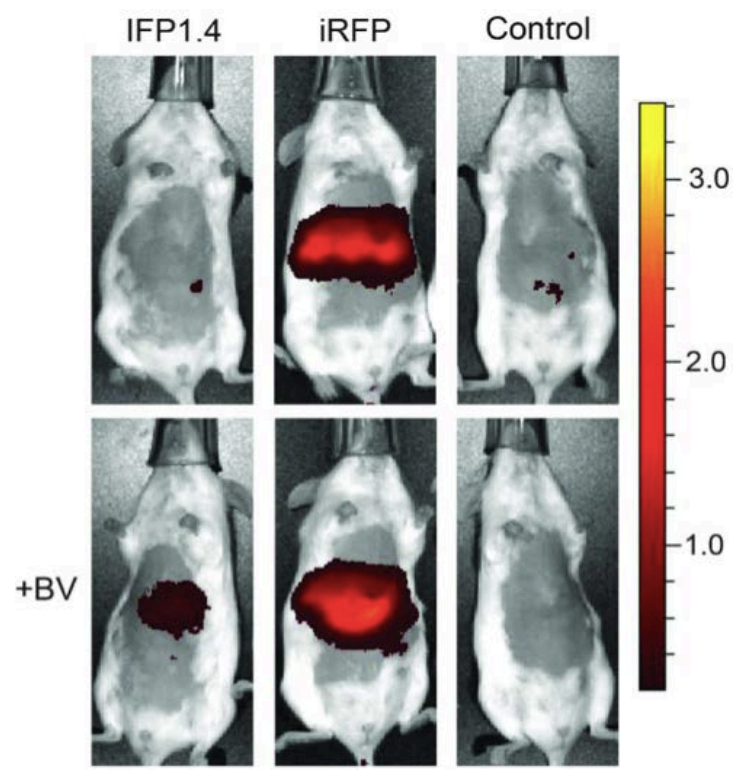

Figura 1.42. Expresión de la proteína iRFP e IFP 1.4 en el hígado de ratones infectados con adenovirus (Ad5) tras la adición o no de biliverdina (Filonov y col., 2011). 
Un estudio reciente del mismo grupo ha analizado el empleo de dos nuevas proteínas infrarrojas, iRFP670 e iRFP720, cuyas nomenclaturas se refieren al pico máximo de emisión, para realizar estudios de imagen multicolor en animales a los que se habían inyectado células cancerígenas que expresaban de forma estable los reporteros. Hasta la fecha son las proteínas infrarrojas fluorescentes con el espectro más desplazado hacia el azul y hacia el rojo, respectivamente, y es esa separación lo que permite su empleo para la adquisición de imágenes en las que dos colores puedan ser identificados a la vez (Shcherbakova y Verkhusha, 2013).

\subsection{EMPLEO DE PARÁSITOS TRANSGÉNICOS PARA EL DESCUBRIMIENTO $Y$ EL DESARROLLO DE NUEVOS FÁRMACOS CONTRA LA LEISHMANIOSIS}

Como se comentó en apartados anteriores, existe una necesidad urgente de obtener nuevos fármacos y drogas para luchar contra los distintos tipos de leishmaniosis en la actualidad debido al fallo de los tratamientos, la elevada toxicidad de los mismos y la aparición de resistencias, además de la ausencia de una vacuna eficaz, tanto profiláctica como curativa, o las dificultades asociadas al control de los vectores invertebrados, principalmente en zonas endémicas. Durante los últimos años la estrategia seguida ha sido la combinación de tratamientos ya conocidos con fármacos desarrollados contra otras enfermedades, como es el caso de la anfotericina B, desarrollada como antimicótico (Oura y col., 1955). Aunque esta aproximación disminuye el tiempo necesario para confirmar la eficacia de un compuesto o aprobar su empleo, la posibilidad de obtener un mecanismo de acción nuevo contra el parásito es muy reducida, y se limita el empleo de fármacos a los ya aprobados con anterioridad (Freitas-Junior y col., 2012).

En este sentido, desde hace unos años existe una mayor conciencia por parte de fundaciones sin ánimo de lucro como la Iniciativa Medicamentos para las Enfermedades Olvidadas (DNDi), y otras instituciones públicas como el "Open Lab" de GlaxoSmithKline para combatir las Enfermedades Olvidadas en el año 2020, entre las que se encuentran la leishmaniosis. Estas organizaciones cuentan con miles de compuestos procedentes de distintas librerías disponibles para ser testados, para lo cual es indispensable contar con infraestructuras, equipo humano y, sobre todo, financiación para ser capaces de encontrar posibles candidatos o "hits" que avancen hasta las etapas finales del desarrollo pre-clínico de nuevos fármacos.

Para identificar nuevos fármacos se pueden seguir dos aproximaciones principales, los estudios basados en una diana conocida o "target-based" y los estudios fenotípicos o "target-free". Para los primeros es necesario identificar y validar las dianas potenciales, tanto genética como químicamente, y aportar evidencia in vivo o al menos en la forma amastigote, de la esencialidad de la misma. Todo ello hace que los estudios basados en dianas conocidas se encuentren aún en las fases iniciales de desarrollo y no se consideren la mejor opción para el desarrollo de nuevos medicamentos (Payne y col., 2007). Por su parte, el testado de compuestos "target-free" no identificaría una molécula específica como diana, ni siquiera una ruta específica, sino que seleccionaría drogas que fueran capaces de eliminar al parásito. Típicamente los estudios fenotípicos son screenings de alto contenido o 
HCS (High-Content Screenings), de tal modo que una vez que son miniaturizados y adaptados a placas de microtitulación, el ensayo puede ser automatizado y llegar a ser compatible con screenings de alto rendimiento o HTS (High-Throughput Screenings), con el fin de testar miles de compuestos, aumentando las probabilidades de identificar "hits" potenciales.

\subsubsection{Estudios HTS en Leishmania}

Históricamente la ausencia de capacidad para realizar screenings fenotípicos a gran escala en Leishmania ha impedido el acceso a cantidades masivas de hits potenciales $\mathrm{y}$, por tanto, a la posibilidad de encontrar candidatos reales contra la enfermedad. En este sentido, se han intentado distintas aproximaciones que han empleado diferentes formas del ciclo de vida del parásito, parásitos transgénicos, diferentes formatos y distintas células hospedadoras. El sistema in vitro permite identificar compuestos que actúan directamente sobre el parásito pero aquéllos que son eficaces debido a su metabolización o cuya acción es mediada a través del sistema inmune del huésped pasarán desapercibidos. Por ello, en muchas ocasiones los tests in vitro no permiten una interpolación real a la situación in vivo (Gupta y Nishi, 2011).

El uso de promastigotes para el testado de compuestos leishmanicidas radica en la simplicidad del sistema y la disponibilidad de grandes cantidades de parásitos. Sin embargo, el metabolismo y la ecología de las formas extracelulares difieren en gran medida de las formas intracelulares (Croft y col., 2006). Otra condición que reduce la acción leishmanicida empleando promastigotes es la baja temperatura a la que el cultivo crece normalmente $\left(24-26^{\circ} \mathrm{C}\right)$, la cual difiere considerablemente de los $37^{\circ} \mathrm{C}$ de la situación in vivo. Además, el empleo de las formas extracelulares representa un cultivo artificial, por lo que carece de importancia para el testado de fármacos. A pesar de ello, existen varios ejemplos del empleo de promastigotes de Leishmania modificados para que expresaran el gen de la luciferasa o la GFP para analizar la actividad leishmanicida de distintos compuestos (Luque-Ortega y col., 2001 368; Chan y col., 2003; Singh y col., 2009). Recientemente, Paloque y colaboradores (2013), validaron el empleo de promastigotes de L. major, $L$. infantum y L. donovani para el ensayo de fármacos anti-Leishmania en términos de linearidad del sistema, sensibilidad, precisión y reproducibilidad según las recomendaciones de la ICH (International Conference on Harmonisation). Este grupo cuantificaba el ATP de las células viables al medir la luz producida por la reacción catalizada por la luciferasa de $P$. pyralis; lo novedoso de este sistema es la adición en el medio de luciferasa y luciferina, sin la necesidad de modificar genéticamente los parásitos.

De forma ideal, un ensayo de este tipo requiere reproducir las condiciones de la situación real en el hospedador definitivo, por lo que las formas de elección serían los amastigotes intracelulares contenidos en las células del huésped. En este punto existen tres aproximaciones, el empleo de i) amastigotes axénicos, ii) infecciones in vitro en distintas líneas celulares o macrófagos peritoneales, o iii) cultivos ex vivo de los órganos infectados. El uso de amastigotes axénicos presenta ciertas ventajas como el empleo de la forma relevante del parásito o la rapidez y simplicidad de su manipulación una vez establecido el cultivo axénico. Sin embargo, existen evidencias de las diferencias existentes entre los amastigotes axénicos y los amastigotes intracelulares en cuando a los perfiles de expresión proteica y su 
susceptibilidad a drogas (Holzer y col., 2006; Pescher y col., 2011); por ello, los hits identificados en estudios HTS empleando cultivos axénicos deben ser re-evaluados y confirmados en ensayos intra-macrófago. De igual modo, las posibles interacciones parásito-hospedador de los fármacos analizados no serán identificados de este modo (Sereno y col., 2007). Uno de los esfuerzos recientes para identificar nuevos fármacos ha sido el HTS de 700.000 compuestos realizado por el Instituto Genómico de la Fundación Novartis (GNF); el ensayó empleó amastigotes axénicos en placas de 1536 pocillos (Bustamante y col., 2011). Otros grupos han analizado la eficacia de fármacos anti-Leishmania en uso clínico en amastigotes axénicos de L. mexicana (Callahan y col., 1997), o en cultivos axénicos de L. infantum o L. donovani transformados con el de la luciferasa (Sereno y col., 2001; Ravinder y col., 2012).

La forma más empleada para testar drogas contra Leishmania es el empleo de amastigotes intracelulares, fluorescentes o bioluminiscentes, en infecciones in vitro de macrófagos peritoneales o diferenciados desde suspensiones de médula ósea de ratón (Bringmann y col., 2013; Aulner y col., 2013), o líneas celulares de macrófagos diferenciados desde monocitos humanos como THP-1 (Jain y col., 2012), U937 (Pulido y col., 2012), o J774 (Ashutosh y col., 2005). El Instituto Pasteur de Corea (IPK) junto con el DNDi desarrolló un HTS/HCS en placas de 384 pocillos para encontrar testar aproximadamente 300.000 compuestos nuevos contra Leishmania, de los cuales se identificaron 350 hits; la célula hospedadora elegida fue la línea monocítica de leucemia humana THP-1, la cual fue infectada con promastigotes metacíclicos de L. donovani (Freitas-Junior y col., 2012).

Cabe tener en cuenta la existencia de variación en la susceptibilidad a los antimoniales pentavalentes en función del modelo utilizado (Sereno y Lemesre, 1997). Aunque esta aproximación presenta ventajas respecto a las dos anteriores y se acerca algo más a la situación in vivo, las infecciones in vitro carecen de las células del sistema inmune presentes en los órganos infectados, las cuales influencian profundamente la replicación de los parásitos o su muerte (Murray y col., 1982; Murray y col., 2000; Alexander y col., 2000). Además, las infecciones in vitro son muy laboriosas técnicamente y pueden contener un número variable de promastigotes no internalizados que permanecen adheridos a los macrófagos.

Por todo ello, el empleo de los cultivos ex vivo procedentes de órganos infectados (bazo o ganglio para LV y LC, respectivamente), es la aproximación que mimetiza más fielmente la situación real de la infección, ya que incluye toda la población celular involucrada en la interacción parásito-hospedador y la forma intracelular del parásito. Esta metodología ha sido validada para analizar la actividad de miles de compuestos en bazos de hámsteres sirios infectados con una cepa de $L$. donovani transfectada con la luciferasa de la luciérnaga P. pyralis, empleando placas de 96 pocillos (Osorio y col., 2011); y recientemente en cultivos ex vivo de ganglios infectados con una cepa bioluminiscente de L. major (Peniche y col., 2014). Debido a la variedad de métodos para establecer la actividad y la potencia de compuestos contra Leishmania spp., es importante tener ensayos de referencia, métodos estandarizados y validados para comparar datos y seleccionar buenos hits y/o series de compuestos. Tras la selección de los hits o las series, se llevarán a cabo estudios de la relación estructura-actividad del compuesto para priorizar las 
distintas clases químicas, se sintetizarán derivados de los mismos y se identificarán las estructuras químicas activas (Freitas-Junior y col., 2012).

\subsubsection{Empleo de parásitos transgénicos en infecciones in vivo de imagen a tiempo real}

Hasta hace relativamente poco tiempo, el análisis de las infecciones parasitarias en el vector mamífero estaba restringido a estudios post-mortem o in vitro. El desarrollo de parásitos transgénicos que expresan reporteros fluorescentes o bioluminiscentes, en combinación con los últimos avances en equipos de imagen, permite la visualización de infecciones parasitarias en animales y aporta información valiosa sobre los mecanismos de la patogénesis, las interacciones parásito-hospedador, el descubrimiento de nuevos nichos de infección y el testado de nuevos fármacos y vacunas potenciales in vivo (Heussler y Doerig, 2006). La imagen biofotónica es una técnica altamente sensible, no tóxica y no invasiva, basada en la detección de luz visible procedente de la excitación de una proteína fluorescente o de la reacción de oxidación catalizada por la enzima luciferasa.

Aunque la luz emitida puede ser débil, el empleo de detectores externos altamente sensibles como las cámaras de carga acoplada (CCD, Charge Coupled Device), permiten detectar la señal lumínica generada. Esta técnica reduce el número de animales necesarios para obtener datos estadísticamente significativos, lo que está en concordancia con dos de los principios de la regla de las Tres Erres, la Reducción del número de animales y el Refinamiento en la manipulación de los mismos; además, a lo largo del mismo experimento se pueden tomar múltiples imágenes del mismo animal, disminuyendo así las variaciones individuales animalanimal (Andreu y col., 2011). Los principales factores que influyen en la sensibilidad de la imagen biofotónica hacen referencia a:

* La propagación de la luz a través de los tejidos del animal.

* Las señales de fondo o ruido de los propios animales (incluido el pelo).

* El nivel de expresión de las proteínas fluorescentes o bioluminiscentes.

* La longitud de onda de excitación (para fluorescencia), v) la disponibilidad $\mathrm{y}$ accesibilidad de los sustratos bioluminiscentes.

* La localización de la señal en el animal, en términos de profundidad y de tipo de tejido.

La imagen bioluminiscente es el método de elección para evaluar la carga parasitaria en órganos internos, ya que es más sensible debido a un ratio positivo señal/ruido (Troy y col., 2004). Pero esta técnica aporta solamente imágenes en dos dimensiones de baja resolución (Dube y col., 2009). Del mismo modo, la imagen bioluminiscente se refiere específicamente a la generación enzimática de luz visible por organismos vivos, por lo que la señal cesará si el animal muere durante el experimento (Lang y col., 2009). Además, requiere de la inyección de luciferina exógena la cual debe ser absorbida y liberada específicamente en el interior de los macrófagos infectados (Millington y col., 2010).Por su parte, la imagen fluorescente está limitada a modelos in vivo de LC, debido a la escasa penetración de la fluorescencia en los tejidos, la dispersión de la luz y la 
autofluorescencia de los mismos. La autofluorescencia de los tejidos es uno de los principales problemas de la imagen fluorescente. La imagen in vivo de tejidos profundos es más factible entre los 650 y los $900 \mathrm{~nm}$, debido a que en esas longitudes de onda se minimiza la absorbancia de la hemoglobina, el agua y los lípidos (Weissleder y Ntziachristos, 2003); por ello, el uso de proteínas fluorescentes situadas en la zona roja o infrarroja del espectro concentra la autofluorescencia en la zona gastrointestinal, debido a la presencia de clorofila en la dieta de los animales; esto se puede solventar mediante el empleo de dietas libres de alfalfa o purificadas (Inoue y col., 2008).

La LC se ha estudiado empleando parásitos fluorescentes y bioluminiscentes. Debido a que las infecciones experimentales en modelos de ratón se parecen en gran medida a las descritas en el ser humano, la imagen in vivo se puede emplear como una aproximación pre-clínica para la selección de drogas leishmanicidas previa a los ensayos clínicos en humanos. Lecoeur y colaboradores (2007), optimizaron la duración de la aplicación tópica de un aminoglicósido en forma de pomada en ratones infectados con una cepa de L. major bioluminiscente. Igualmente, otro trabajo estableció el efecto profiláctico de una vacuna recombinante en animales infectados con una cepa de L. amazonensis que expresaba la proteína fluorescente EGFP (Mehta y col., 2008).

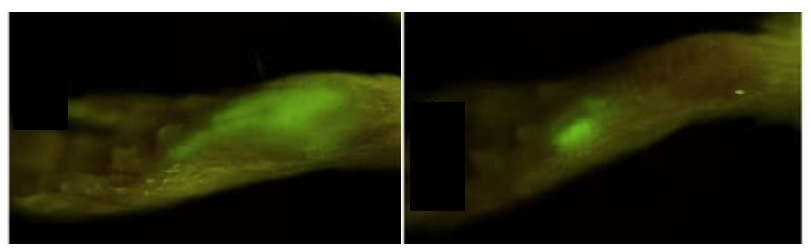

Figura 1.43. Inmunoterapia de un modelo de LC causado por una cepa de L. amazonensis tranfectada con el gen de la proteína fluorescente EFGP y tratada con la vacuna recombinante Leish $111 \mathrm{f}+$ MPL-SE. Los animales recibieron el tratamiento por vía subcutánea en la almohadilla infectada los días 7, 14 y 24 post-infección, y PBS los mismos días en el grupo control. Imágenes representativas de las almohadillas plantares de los animales infectados (izquierda) y los animales vacunados (derecha) a los 24 días de infección (Mehta y col., 2008).

Debido a la dificultad en la obtención de modelos de LV que permitan la cuantificación de la carga parasitaria mediante la imagen biofotónica, existe un número limitado de trabajos hasta la fecha. Un trabajo reciente demostró la utilidad de un modelo murino de LV empleando una cepa de L. infantum que expresaba el gen de la luciferasa, para la caracterización de la colonización parasitaria del hígado en primer lugar, y posteriormente del bazo del animal; tras seis semanas de infección, este modelo fue empleado para estudiar el efecto de la miltefosina en un tratamiento de 5 días y para demostrar la existencia de un nuevo sitio de proliferación parasitaria, la grasa mesentérica intra-abdominal (Michel y col., 2011). 


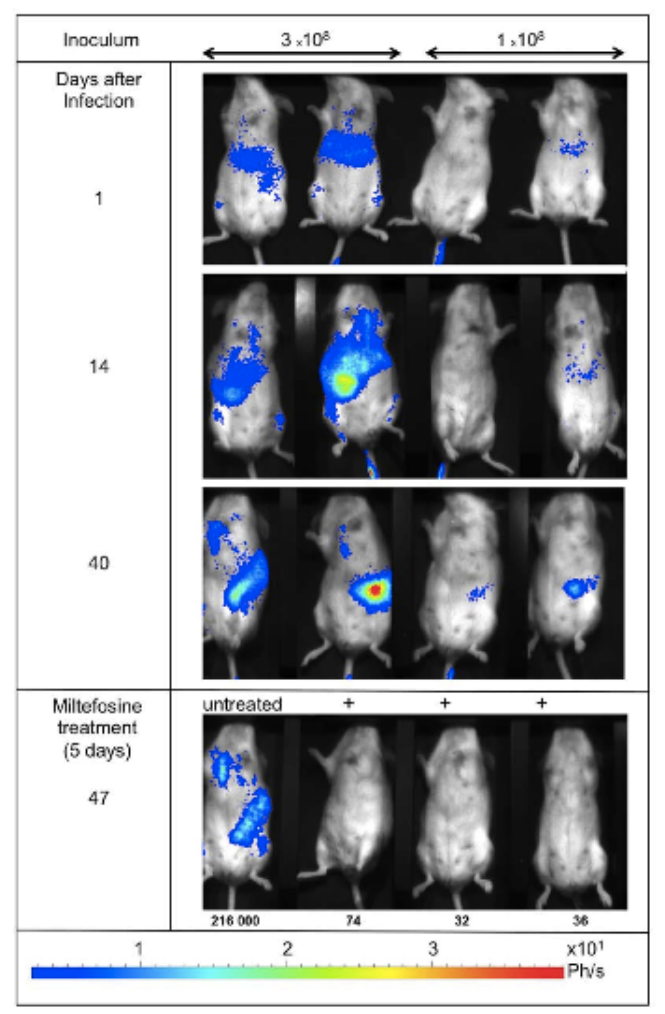

Figura 1.44. Monitorización de la infección causada por una cepa de L. infantum que expresaba el gen de la luciferasa y su aplicación para el testado in vivo de fármacos. La imagen bioluminiscente muestra la colonización hepática típica seguida de la infección en el bazo. El día 40 post-infección,

los animales fueron tratados con miltefosina durante cinco días; la eficacia del tratamiento se confirmó mediante la pérdida de la señal bioluminiscente (Michel y col., 2011).

\subsection{INTERCAMBIO GENÉTICO EN TRIPANOSOMÁTIDOS}

Durante años, se propuso que el proceso de reproducción de muchos protozoos parásitos, entre ellos los géneros Plasmodium, Trypanosoma o Leishmania, era estrictamente clonal, lo que fue definido como la "teoría clonal". En esos años ya se había sugerido una reproducción sexual debido, principalmente, a la diploidía encontrada en gran cantidad de aislados; sin embargo, estudios basados en polimorfismos indicaban que procesos típicos de la reproducción sexual, como la segregación o la recombinación, estaban ausentes o aparecían con una frecuencia realmente baja en poblaciones naturales (Tibayrenc y col., 1990). Durante esos años se habían analizado algunos procesos de recombinación sexual obtenidos en el laboratorio, para T. brucei (Jenni y col., 1986), o P. falciparum (Walliker y col., 1987), pero también otros autores habían postulado que la recombinación genética ocurría igualmente en poblaciones naturales de T. brucei (Tait, 1980), y Leishmania (Evans y col., 1987).

El intercambio genético contribuye a la diversidad fenotípica de las poblaciones naturales, siendo de gran importancia el análisis de la progenie híbrida para la identificación de genes que controlen mecanismos de virulencia, el tropismo tisular y la resistencia a fármacos. 


\subsection{1. ¿Teoría clonal o reproducción sexual?}

La teoría clonal establece que en las poblaciones naturales el proceso de recombinación no es lo suficientemente frecuente como para romper el patrón de la "evolución clonal predominante" (PCE, Preponderant Clonal Evolution) (Tibayrenc y Ayala, 2013). Las dos consecuencias fundamentales de la reproducción sexual son la segregación y la recombinación; la segregación involucra a alelos del mismo locus, mientras que la recombinación se refiere a la relación existente entre alelos de distintos loci. En un estudio llevado a cabo por Tibayrenc y colaboradores (1990), este grupo apoyaba la teoría clonal basándose en distintos criterios que estaban en contra de los procesos de segregación y recombinación en poblaciones parasitarias naturales. Una de las evidencias que apoyaba la ausencia de segregación era la presencia de una heterozigosidad constante en las poblaciones estudiadas, la cual aparecía en los mismos loci en todos las muestras analizadas de forma independiente tanto en T. cruzi (Tibayrenc y Ayala, 1987), como en T. brucei (Tait y col., 1985). La ausencia de segregación en los genotipos era el segundo criterio, ya que la reproducción sexual genera individuos homozigotos y heterozigotos y la ausencia de todos los posibles genotipos iba en relación con la heterozigosidad observada. El último criterio establecía la desviación del principio de Hardy-Weinberg, existiendo ejemplos en $T$. brucei (Tait y col., 1985) y T. cruzi (Tibayrenc y col., 1984). Las evidencias que iban en contra de la existencia de recombinación incluían i) la sobrerrepresentación de genotipos predominantes y su distribución en zonas geográficas amplias, ii) la ausencia de genotipos recombinantes, iii) el desequilibrio de ligamiento, el cual estaba cercano al valor máximo posible para las frecuencias alélicas observadas y, iv) la asociación entre marcadores genéticos no relacionados, lo que apoya la teoría de la reproducción clonal (Hartl, 1992). Con todo ello, estos autores proponían que la reproducción uniparental era predominante en las poblaciones naturales y que generaba clones estables en el tiempo y en el espacio.

Sin embargo, la teoría clonal de los protozoos parásitos ha sido recientemente reescrita por distintas investigaciones que establecen que los procesos de recombinación son mucho más frecuentes de lo que se pensaba, o de que la homogamia y la autofecundación deberían incluirse dentro de la definición de la PCE, ya que el resultado más evidente de todas ellas es la restricción del proceso de recombinación (Tibayrenc y Ayala, 2013). Por otro lado, estudios genéticos poblaciones han sido empleados para identificar signos de intercambio genético, como la ausencia de desequilibrio de ligamiento, la diversidad de las secuencias alélicas, la existencia de una amplia heterozigosidad o la presencia de híbridos genéticos (Schmid-Hempel y col., 2011).

Sin embargo, los casos experimentales de intercambio genético en tripanosomátidos son aún escasos. Aunque estos organismos se reproducen principalmente por fisión binaria, el análisis electroforético de variantes enzimáticas en poblaciones naturales (Tait, 1983; Tait, 1980), junto con estudios de polimorfismos de longitud de fragmentos de restricción (RFLP) de genes codificantes de enzimas glicolíticas y tubulina en T. brucei habían evidenciado de que este organismo era diploide (Gibson y col., 1985). Jenni y colaboradores (1986), demostraron por primera vez la formación de híbridos de T. brucei en coinfecciones experimentales de dos clones diferentes del parásito y moscas tsetse; la progenie híbrida analizada era heterozigota para los marcadores parentales 
empleados. En este estudio los autores ya apuntaban la posibilidad de meiosis en las cepas parentales seguido de la fusión de una forma haploide del parásito. Otra prueba de que el sistema genético en T. brucei seguía una herencia mendeliana e involucraba meiosis, fue obtenida por MacLeod y colaboradores en el año 2005; los autores aislaron numerosos clones obtenidos de los cruces entre dos clones aislados de T. $b$. brucei y otro entre T. b. brucei y T. b. gambiense tipo 2 , y analizaron la herencia de 11 marcadores micro y minisatélite localizados en distintos cromosomas. Los resultados mostraron que los alelos segregaban según las frecuencias esperadas y que los alelos situados en distintos cromosomas segregaban de forma independiente, lo que aportaba una evidencia inequívoca de que el intercambio genético había tenido lugar. Trypanosoma cruzi, el agente responsable de los casos de tripanosomiasis en el continente americano, también era capaz de experimentar intercambio genético. Dos clones de T. cruzi fueron modificados para expresar distintos marcadores de resistencia antibiótica, y los clones doble resistentes obtenidos de la co-infección en células Vero, mostraron la fusión de los genotipos parentales, la pérdida de alelos, recombinación homóloga y la herencia uniparental del ADN del maxicírculo del kinetoplasto. La obtención de la progenie híbrida en las células de mamífero implicaba que el intercambio genético podía darse en los reservorios vertebrados de T. cruzi, y no sólo en el vector invertebrado (Gaunt y col., 2003).

La primera demostración de que Leishmania era capaz de experimentar un ciclo sexual en el vector flebotomino fue presentada por Akopyants y colaboradores en 2009. Los autores emplearon dos cepas diferentes de L. major que expresaban dos marcadores distintos de resistencia a antibióticos, L. major LV39c5(HYG) y $L$. major Friedlin(SAT). La co-infección de ambas cepas con el vector P. duboscqi originó clones híbridos doble resistentes, los cuales fueron empleados para estudiar la segregación de loci independientes a la situación de los genes de resistencia antibiótica, mediante análisis de polimorfismos de nucleótido simple (SNPs) y secuenciación. Cada parental era homozigoto para cada marcador ensayado, mientras que todos los clones híbridos habían heredado los alelos de los dos parentales, presentando un genotipo heterozigoto, y el ADN del maxicírculo del kinetoplasto procedía exclusivamente de uno de ellos. Sin embargo, un porcentaje importante de la progenie híbrida era triploide, por lo que el mecanismo preciso por el cual había tenido lugar el intercambio seguía siendo incierto.

\subsubsection{Ploidía e intercambio genético en Leishmania}

Aunque los organismos del género Leishmania se multiplican por fisión binaria, la existencia de un genoma diploide sugiere la idea de la presencia de reproducción sexual. Las evidencias proporcionadas por los "knockouts" génicos, polimorfismos de sitio de restricción, recombinaciones génicas y alteraciones del cariotipo, apuntan a que el estado predominante es el de la diploidía. Las alteraciones del cariotipo en un cromosoma de $350 \mathrm{~kb}$ de L. major generaron un cromosoma igual al salvaje y una versión agrandada del mismo, cada uno de ellos presentes al $50 \%$ del nivel del cromosoma original, indicando un estado diploide (Iovannisci y Beverley, 1989). Además, la impresión general de que las poblaciones naturales de Leishmania eran a menudo aneuploides y que poseían una habilidad especial para tolerar cambios en el número de cromosomas (Beck y Ullman, 1991), fue 
confirmada por Cruz y colaboradores (1993); este grupo intentó generar, sin éxito, una cepa de L. major homozigota para el gen de la dihidrofolato reductasatimidilato sintasa ( $d h f r$-ts) mediante reemplazamiento doble con dos marcadores de resistencia antibiótica. En su lugar, obtuvieron principalmente líneas aneuploides y tetraploides. Para explicar la baja frecuencia de heterozigotos (ausencia de segregación) observados en poblaciones naturales de Leishmania, estos autores propusieron un estado de "aneuploidía transitoria" que podría generar progenie homozigota y heterozigota a partir de unos progenitores heterozigotos. Gueiros-Filho y Beverley (1996), indicaron que la tasa de pérdida espontánea de heterozigosis ( $\mathrm{LOH})$, es de $10^{-5}$ células/generación durante la selección en contra de las líneas heterozigóticas para la $d h f r-t s$, indicando que son los mecanismos que llevan a la $\mathrm{LOH}$, los que mantienen la homozigosis en las poblaciones de Leishmania. Recientemente, Lachaud y colaboradores (2014), ha analizado mediante hibridación fluorescente in situ (FISH), la ploidía de células individuales de tres especies del Viejo Mundo (L. infantum, L. donovani y L. tropica), y una del Nuevo Mundo (L. amazonensis), para seis cromosomas diferentes. Los resultados establecen la existencia de un mosaico aneuploide como una característica general del género Leishmania. Esta aneuploidía generalizada permitiría el mantenimiento de la diversidad genotípica sin la necesidad de gametos, cuya existencia en Leishmania aún no ha sido demostrada.

A pesar de la baja frecuencia del intercambio genético, de forma experimental en el laboratorio o en la naturaleza, existen varios ejemplos de genotipos híbridos en aislados de campo que involucran distintas especies de Leishmania. En 1991, Kelly y colaboradores caracterizaron mediante estudios de isoenzimas y de cariotipo dos cepas híbridas de Leishmania aisladas de animales salvajes en un foco zoonótico de LC en Arabia Saudí, las cuales presentaban características de L. major y L. arabica; además, determinaron que los híbridos contenían los minicírculos del ADN del kinetoplasto de L. major y no de L. arabica. Otros estudios encontraron híbridos de L. braziliensis y L. panamensis en Nicaragua (Belli y col., 1994), y de L. braziliensis y L. peruviana en Perú (Dujardin y col., 1995; Nolder y col., 2007). La primera referencia de la existencia de híbridos entre L. infantum y L. major, dos especies genéticamente muy distantes, fue descrito por Ravel y colaboradores en 2006, y fueron obtenidos de pacientes inmunocomprometidos en Portugal. En las poblaciones naturales, los híbridos originados generarían, potencialmente, una descendencia con una ventaja selectiva importante, por lo que estas transferencias genéticas podrían generar fenotipos más virulentos o resistentes a los fármacos empleados en el tratamiento de la leishmaniosis.

Distintas investigaciones que confirman la existencia de intercambio genético en Leishmania han sido descritas. Kreutzer y colaboradores (1994), evidenciaron la reproducción sexual de las formas amastigotes de distintos aislados de Leishmania mediante la determinación de los niveles de ADN en estudios de microespectrofotometría, en comparación con cultivos de promastigotes extracelulares. Los datos de algunos amastigotes del cultivo eran el doble de los promastigotes, lo que podía indicar que tras la fusión de los núcleos (4n), se seguía un proceso meiótico que generaba valores $2 \mathrm{n}$ de $\mathrm{ADN}$, volviendo a los niveles de los promastigotes. Otros estudios han analizado la formación de híbridos en el interior del vector flebotomino. Volf y colaboradores (2007), compararon el desarrollo de dos cepas híbridas de L. major/L. infantum en los vectores $L$. 
longipalpis y P. papatasi. En P. papatasi, vector natural de L. major y no de $L$. infantum, los híbridos generaban infecciones tardías con un alto número de promastigotes metacíclicos; en el vector permisivo L. longipapis, las dos cepas híbridas se desarrollaron adecuadamente. Además, los híbridos expresaban el LPG de L. major, lo que facilitaba su supervivencia en el intestino medio de P. papatasi. Este estudio sugería que en la naturaleza, las cepas híbridas podrían desarrollarse en vectores permisivos y no permisivos, aumentando así su distribución geográfica a nuevos focos de infección. Un estudio reciente confirmó que el intercambio genético en Leishmania no presentada barreras interespecíficas; emplearon distintas cepas de L. major aisladas de diferentes regiones geográficas que expresaban distintos genes de resistencia a antibióticos, y analizaron su capacidad de cruzamiento y el tiempo necesario para la obtención de híbridos en su vector natural P. duboscqi, y también en L. longipalpis. Al igual que en otros estudios previos, la herencia del ADN del kinetoplasto fue uniparental y las eficiencias de recuperación de híbridos fueron similares en todos los cruces propuestos, lo que eliminaba la idea de que existen "tipos" de cruzamiento específicos que limitan el intercambio genético (Inbar y col., 2013).

Otra aproximación de generar híbridos de Leishmania ha sido desarrollada por Coelho y colaboradores (2012). Este grupo examinó la capacidad obtener cepas híbridas mediante la electroporación del ADN genómico de células "donantes" de $L$. major en parásitos "receptores" de L. infantum, lo que podría ser de vital utilidad para analizar in vitro las funciones de genes específicos en los parásitos del género Leishmania. Por otro lado, la tecnología de la secuenciación masiva ha sido empleada para cuantificar la frecuencia de reproducción sexual en 11 aislados de $L$. infantum obtenidos desde moscas infectadas y un aislado procedente de un paciente infectado en un foco de Turquía donde no existen, actualmente, datos de casos de LV. El patrón irregular de heterozigosidad obtenido, sugiere que esas cepas se originaron de un cruce entre dos especies genéticamente diferentes del complejo L. donovani. Los análisis subsiguientes de los bloques heterozigotos encontrados indican que la población se había reproducido por fisión binaria tras la hibridación, pero que algún proceso de recombinación había tenido lugar con seguridad (Rogers y col., 2014). La existencia creciente de estudios sobre el intercambio genético en Leishmania apoya la idea de la recombinación sexual en estos parásitos, y aporta una explicación acerca de la expansión de los vectores y los reservorios, y las presentaciones clínicas de la enfermedad en los nuevos focos geográficos.

\subsubsection{Empleo de cepas fluorescentes en estudios de intercambio genético}

Una aplicación reciente de las proteínas fluorescentes es su utilización como biomarcadores potenciales en estudios de intercambio genético en tripanosomátidos, tanto en T. brucei como en Leishmania. En el año 2001, Bingle Ly colaboradores, generaron una cepa de T. brucei que expresaba genes de proteínas fluorescentes bajo el control de un represor de tetraciclina (Tet), con el fin de mostrar que el intercambio tenía lugar en las glándulas salivares del insecto y no en la zona intestinal. Uno de los clones parentales fue transfectado con el gen codificante de la GFP y el marcador de resistencia antibiótica a higromicina y geneticina, respectivamente. Los híbridos obtenidos eran fluorescentes y resistentes a los dos antibióticos, lo que era consistente con la segregación 
meiótica y la redistribución de los genes codificantes de la GFP y del represor Tet. La fluorescencia de los clones híbridos fue encontrada en las glándulas salivares de la mosca, pero no en el intestino medio. En un estudio posterior, el mismo grupo observó híbridos amarillos en las glándulas salivares de las moscas, como consecuencia de la combinación de la fluorescencia roja y verde, tras co-infectar dos cepas distintas de T. brucei que sobreexpresaban las proteínas fluorescentes GFP y RFP, respectivamente. Los clones híbridos mostraron una herencia biparental de los genomas nuclear y del kinetoplasto, mientras que la recuperación de híbridos diploides, triploides y tetraploides parecía no ir en concordancia con la herencia mendeliana de los genes reporteros (Gibson y col., 2008).

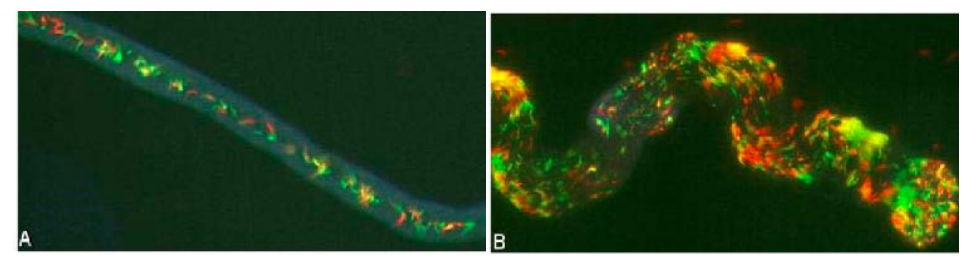

Figura 1.45. Visualización de híbridos amarillos de T. brucei junto con tripanosomas rojos y verdes en las glándulas salivares del vector invertebrado. A) Ductos salivares el día 27 post-infección; B) porción de la glándula salivar el día 20 post-infección (Gibson y col., 2008).

Un año después, el mismo grupo demostró el cruzamiento intraclonal de T. $b$. brucei en el interior del vector invertebrado, lo que iba en contra de investigaciones previas que establecían que la recombinación tenía lugar únicamente cuando otra cepa distinta estaba presente. Los clones parentales, procedentes de la misma cepa, habían sido modificados para que expresaran los genes de las proteínas fluorescentes GFP y RFP, respectivamente, por lo que la presencia de tripanosomas amarillos indicaba el cruzamiento intraclonal y la segregación de los genes reporteros. La frecuencia de recuperación de híbridos fue significativamente diferente a los cruces interclonales. Aunque no existían aún "tipos" de cruzamiento identificados en T. brucei, parecía que los tripanosomas tenían algún mecanismo por el cual se reconocían entre ellos, basándose en los resultados tan dispares entre los clones recuperados de los cruces entre cepas distintas y la misma cepa (Peacock y col., 2009). Recientemente, se han identificado cuatro genes homólogos de genes meióticos (HMGs, Homologs of Meiosis-specific Genes), en el genoma de T. brucei, definiéndose así una etapa desconocida del desarrollo de estos parásitos en las glándulas salivares del vector invertebrado. Su expresión se analizó mediante la generación de líneas transgénicas que contenían el gen HMG fusionado a la proteína fluorescente YFP, visualizándose la señal fluorescente en infecciones clonales y mixtas, previo a la fusión celular (Peacock y col., 2011).

Peacock y colaboradores (2014a), han explotado el empleo de las proteínas fluorescentes GFP y RFP para demostrar la existencia de gametos haploides en tripanosomas derivados de las glándulas salivares de las moscas; la visualización de la interacción y fusión de estas células tuvo lugar ex vivo durante el periodo en el que los genes específicos de meiosis tenían una mayor expresión. La medida de los contenidos de ADN nucleares mostró que estos promastigotes eran haploides 
en comparación con los parásitos metacíclicos diploides. La capacidad de los organismos unicelulares de reconocerse entre ellos es de gran importancia a la hora de elegir la mejor opción para el cruzamiento. La compatibilidad del cruzamiento suele estar controlada por la existencia de "tipos" (MTs, Mating Types), ya que los cruces entre células de distinto MT son más frecuentes y favorables evolutivamente, como ha sido evidenciado en cruces intraclonales e interclonales en T. brucei. Además, este grupo ha analizado la compatibilidad de los cruzamientos y la existencia de "tipos" específicos (MTs) en infecciones ex vivo con tripanosomas aislados del vector invertebrado. La expresión de las proteínas fluorescentes GFP y RFP permitió observar que la formación de los gametos comienza poco después de poner en contacto las células rojas y verdes fluorescentes, tanto del mismo, como de un genotipo distinto (Peacock y col., 2014b).

En Leishmania, la primera visualización de híbridos fluorescentes de L. donovani fue llevada a cabo por Sadlova y colaboradores (2011). En este estudio se realizaron infecciones de dos cepas distintas de $L$. donovani que expresaban los genes de resistencia antibiótica a higromicina y neomicina, junto con los genes codificantes de las proteínas fluorescentes GFP y RFP, respectivamente, en los vectores $P$. perniciosus y L. longipalpis. La recuperación de los híbridos amarillos fluorescentes se localizó en la sangre semi-digerida dos días después de la alimentación de las moscas, mediante estudios de microscopía, y también se confirmó por estudios de citometría. Sin embargo, los híbridos aislados no fueron viables in vitro tras la adición en el medio de cultivo de los dos antibióticos de selección. 

OBJETIVOS 


\section{OBJETIVOS}

1. Establecimiento de un modelo de cribado de fármacos de alto rendimiento mediante ensayos HTS (High Throughput Screening), empleando el sistema ex vivo de explantes esplénicos de ratones BALB/c infectados con una cepa infrarroja fluorescente de Leishmania infantum BCN 150.

2. Desarrollo de un sistema de seguimiento de una infección in vivo a tiempo real causada por una cepa roja fluorescente de $L$. major con el fin de monitorizar y evaluar la efectividad de una vacuna experimental contra la leishmaniosis cutánea.

3. Demostración de la existencia de intercambio genético intraclonal en el vector flebotomino Phlebotomus perniciosus entre dos cepas modificadas de L. infantum BCN 150 que sobreexpresan dos proteínas fluorescentes $y$ dos marcadores de resistencia antibiótica diferenciales. 



\section{ARTÍ́CULOS CIENTÍFICOS}


"Gimatecan and other camptothecin derivatives poison Leishmania DNAtopoisomerase IB leading to a strong leishmanicidal effect". Prada CF., Álvarez-Velilla R., Balaña-Fouce R., Prieto C., Calvo-Álvarez E., Escudero-Martínez JM., Requena JM., Ordóñez C., Desideri A., Pérez-Pertejo Y., Reguera RM. (2013) Biochem Pharmacol. 


\title{
Gimatecan and other camptothecin derivatives poison Leishmania DNA-topoisomerase IB leading to a strong leishmanicidal effect
}

\author{
Christopher F. Prada ${ }^{a, 1}$, Raquel Álvarez-Velilla ${ }^{a, 1}$, Rafael Balaña-Fouce ${ }^{\mathrm{a}, *}$, Carlos Prieto ${ }^{\mathrm{b}}$, \\ Estefania Calvo-Álvarez ${ }^{\mathrm{a}, 1}$, Jose Miguel Escudero-Martínez ${ }^{\mathrm{a}, 1}$, José María Requena ${ }^{\mathrm{c}}$, \\ César Ordóñez $^{\mathrm{a}, 1}$, Alessandro Desideri ${ }^{\mathrm{d}}$, Yolanda Pérez-Pertejo ${ }^{\mathrm{a}, 1}$, Rosa M. Reguera ${ }^{\mathrm{a}, 1}$ \\ a Departamento de Ciencias Biomédicas, Universidad de León, Campus de Vegazana s/n, 24071 León, Spain \\ ${ }^{\mathrm{b}}$ Instituto de Biotecnología de León (INBIOTEC), Parque Científico de León, Avenida Real 1, 24006 León, Spain \\ 'Departamento de Bioquímica y Biología Molecular, Centro de Biología Molecular "Severo Ochoa" c/Nicolás Cabrera, 1, 28049 Madrid, Spain \\ 'Department of Biology, University of Rome "Tor Vergata" Via della Ricerca Scientifica 1, 00133, Roma, Italy
}

\section{A R T I C L E I N F O}

\section{Article history:}

Received 14 December 2012

Accepted 22 February 2013

Available online 1 March 2013

\section{Keywords:}

DNA topoisomerase IB

Gimatecan

Camptothecin

Splenic explants

Leishmania spp.

\begin{abstract}
A B S T R A C T
The aim of this work is the in vitro and ex vivo assessment of the leishmanicidal activity of camptothecin and three analogues used in cancer therapy: topotecan (Hycantim ${ }^{(\mathbb{R}}$ ), gimatecan (ST1481) and the prodrug irinotecan $\left(\right.$ Camptosar $^{\circledR}$ ) as well as its active metabolite SN-38 against Leishmania infantum. The activity of camptothecin and its derivatives was studied on extracellular L. infantum infrared-emitting promastigotes and on an ex vivo murine model of infected splenocytes with L. infantum fluorescent amastigotes. In situ formation of $\mathrm{SDS} / \mathrm{KCl}$ precipitable DNA-protein complexes in Leishmania promastigotes indicated that these drugs are DNA topoisomerase IB poisons. The inhibitory potency of camptothecin derivatives on recombinant L. infantum topoisomerase IB was assessed in vitro showing that gimatecan is the most active compound preventing the relaxation of supercoiled DNA at submicromolar concentrations. Cleavage equilibrium assays in Leishmania topoisomerase IB show that gimatecan changes the equilibrium towards cleavage at much lower concentrations than the other camptothecin derivatives and that this effect persists over time. Gimatecan and camptothecin were the most powerful compounds preventing cell growth of free-living L. infantum promastigotes within the same concentration range. All these compounds killed L. infantum splenocyte-infecting amastigotes within the nanomolar range. The amastigote form showed higher sensitivity to topoisomerase IB poisons (with high therapeutic selectivity indexes) than free-living promastigotes. All the compounds assayed poisoned L. infantum DNA topoisomerase IB leading to a strong leishmanicidal effect. Camptothecin derivatives are suitable for reducing the parasitic burden of ex vivo infected splenocytes. The selectivity index of gimatecan makes it a promising drug against this neglected disease.
\end{abstract}

(c) 2013 Elsevier Inc. All rights reserved.

\section{Introduction}

Visceral leishmaniasis in Europe is a disease caused by the protozoan pathogen Leishmania infantum that affects all countries of the Mediterranean region. The disease has a low prevalence in humans - the definitive host - but not in dogs, which act as reservoirs of the parasite. The risk of human disease significantly increased in immunosuppressed individuals mainly

\footnotetext{
Abbreviations: Top, DNA topoisomerases; TopIB, DNA topoisomerase IB; LdTopIB, L. donovani TopIB; LiTopIB, L. infantum TopIB; IFP1.4, infrared fluorescent protein 1.4; $\mathrm{SI}_{48 \mathrm{~h}}$, selectivity index at $48 \mathrm{~h}$; MDR-1, multidrug resistant protein 1 .

* Corresponding author. Tel.: +34 987 291257; fax: +34 987291252.

E-mail address: rbalf@unileon.es (R. Balaña-Fouce).

1 Tel.: +34 987 291257; fax: +34987 291252.
}

linked to HIV, but due to highly active antiretroviral therapies its presence has dramatically decreased [1]. Current pharmacopoeia against leishmaniasis includes old-fashioned pentavalent antimonium derivatives, as well as amphotericin $\mathrm{B}$, paromomycin and alkylphospholipids [2]. Most of them have many undesirable side effects or require parental administration and longterm treatments, which can make treatment difficult to adhere to [3].

Searching for differentiable targets between the host and pathogen is a recognized strategy for designing new drugs. Type IB DNA topoisomerases (TopIB) were indicated as putative targets in proliferative processes when their mechanism of action was originally shown [4]. Since then, numerous compounds have shown antiproliferative effects: (i) by interfering with the catalytic properties of enzymes (TopIB inhibitors) or (ii) by stabilizing the 
enzyme-DNA complex - a transient step of all Top activities - that can be hindered in time by many compounds (TopIB poisons). TopIB poisons prevent the religation step and produces single DNA breaks that interfere with the replication fork of the dividing cells [5]. An amazing result found in 2003 was that L. infantum TopIB (LiTopIB) was a heterodimeric enzyme encoded by two genes that were placed on different chromosomes [6]. This characteristic is only shared by certain phylogenetically close microorganisms such as Trypanosoma cruzi and T. brucei [7]. Despite these differences, most of the domains related to the enzymatic activity are conserved between both subunits, which are interconnected by two polypeptide extensions that play the role of a putative linker. This region is not needed for TopIB activity, but it contributes to DNA binding and camptothecin inhibition, theoretically by slowing down the religation step of the nicking-closing reaction [8-10].

Camptothecin and derivatives, known as TopIB poisons, develop their function by binding in a specific and reversible manner to the transient DNA-enzyme complexes [11]. These drugs effectively target the TopIB-DNA binary complex, while they do not bind to the enzyme alone and display a weak affinity for DNA in the absence of the enzyme [12]. The presence of cleavage complexes generates collisions with the replication fork, causing DNA breaks by converting transient complexes to permanent strand damage and consequently making these compounds powerful anticancer drugs. Camptothecin in fact shows a remarkable antiproliferative potential in vitro against a wide range of tumor cells in the submicromolar range $[13,14]$ and it has been the first compound described as a specific inhibitor of eukaryotic cell TopIB with no effect on the bacterial TopIA and a well-defined mechanism of action. The development of camptothecin derivatives against several types of cancer has resulted in two watersoluble compounds currently used in clinical practice: topotecan (Hycantim ${ }^{\mathbb{R}}$ ) and the pro-drug irinotecan (Camptosar ${ }^{\mathbb{R}}$ ). In addition a third compound, gimatecan (ST1481) is an orphan drug that is being studied in clinical phase II against astrocytoma, glioblastoma and oligodendroglial tumors [15].

TopIB is essential for DNA replication, recombination and repair mechanisms. Most organisms are unable to survive in the absence of this enzyme [16]. Previous works have unsuccessfully tried to create Leishmania [17] or T. brucei [18] strains lacking the small monomer or both protomers, respectively. For these reasons and because of distinct structural differences between human and leishmanial TopIB, this protein is considered a valuable target for chemotherapy [19].

This paper explains the effect of these camptothecin derivatives on an ex vivo murine model of infected splenocytes with L. infantum. Furthermore, the in vitro effect of these compounds reveals for the first time their ability to trap TopIB-DNA covalent complexes on Leishmania parasites, thus preventing the religation step at micromolar concentrations.

\section{Materials and methods}

\subsection{Reagents and culture media}

Pyrococcus furiosus (Pfu), klenow polymerases and restriction enzymes were acquired from Roche (Roche Farma SA, Spain) and GE Healthcare (Spain). T4 DNA ligase was obtained from Stratagene (La Jolla, CA, USA). Cell culture media, camptothecin, irinotecan and SN-38 were purchased from Sigma (Sigma-Aldrich, Spain). Topotecan (Hycantim ${ }^{\mathbb{R}}$ ) was obtained from GlaxoSmithKline (UK). Gimatecan and camptothecin-N-oxide were kind gifts of Sigma Tau to Alessandro Desideri. Primers for PCR amplification were from Sigma Genosys (UK).

\subsection{Biological material}

L. infantum-IFP1.4 promastigotes and infecting amastigotes were obtained by stable transfection of $L$. infantum (BCN-150 strain) with the pLEXSY-IFP1.4 vector [20]. This vector contains the 987 bp ORF region of the infrared fluorescent protein 1.4 (IFP1.4) derived from Discosoma sp., [21] kindly provided by Dr. Roger Y. Tsien (Department of Pharmacology; Department of Chemistry and Biochemistry, University of California, San Diego, USA).

To obtain naturally amastigote-infected splenocytes cultures, $\mathrm{BALB} / \mathrm{c}$ mice were inoculated intraperitoneally with $10^{8} \mathrm{~L}$. infantum-IFP1.4 purified metacyclic promastigotes [22]. Five weeks post-infection spleens were aseptically dissected and infected splenocytes were cultured as described previously [20]. Different concentrations of miltefosine (included as positive control) and camptothecin derivatives were administered to the explants for $48 \mathrm{~h}$. The viability of infecting amastigotes was assessed registering the fluorescence emission at $708 \mathrm{~nm}$ in an Odyssey (Li-Cor) infrared imaging system. To determine the cytotoxicity of the drugs in mammalian cells, the Alamar Blue staining method was used on drug-exposed splenocytes derived from uninfected mice, according to manufacturer's recommendations. The animal research described in this manuscript complied with Spanish (Ley 32/2007) and European Union Legislation (2010/ $63 / \mathrm{UE}$ ). The used protocols were approved by the Animal Care Committee of Universidad de León (Spain).

\subsection{DNA relaxation assays}

Cloning of LiTopIB ORFs (encoding large and small subunits), expression and purification of the enzyme were carried out as previously described [9]. TopIB activity was assayed by the relaxation of negatively supercoiled plasmid DNA. The reaction mixture, in a total volume of $20 \mu \mathrm{L}$, contained $0.5 \mu \mathrm{g}$ of supercoiled DNA from the pBluescript SK(-) phagemid (pSK), $10 \mathrm{mM}$ Tris- $\mathrm{HCl}$ buffer $\mathrm{pH} 7.5,5 \mathrm{mM} \mathrm{MgCl}_{2}, 0.1 \mathrm{mM}$ EDTA, $15 \mu \mathrm{g} / \mathrm{mL}$ bovine serum albumin, $50 \mathrm{mM} \mathrm{KCl}, 1$ unit of the leishmanial enzyme and $1 \mu \mathrm{L}$ of the tested drugs at different concentrations (dose dependent) or at a fixed drug concentration $(75 \mu \mathrm{M})$ at different time points ranging from 0.2 to $15 \mathrm{~min}$ (time-course). Reaction mixtures were incubated at $37^{\circ} \mathrm{C}$. Enzyme reactions were stopped by the addition of up to $1 \%$ SDS (w/v) (final concentration) and digested with $1 \mathrm{mg} / \mathrm{mL}$ proteinase $\mathrm{K}$ at $37^{\circ} \mathrm{C}$ during one extra hour to remove protein that remained attached to the DNA fragments. The extent of plasmid DNA relaxation was assessed in $1 \%$ agarose gels by electrophoresis in $0.1 \mathrm{M}$ Tris borate EDTA buffer $(\mathrm{pH} 8.0)$ at $2 \mathrm{~V} / \mathrm{cm}$ for $16 \mathrm{~h}$. Gels were visualized with UV illumination after staining with ethidium bromide $(0.5 \mu \mathrm{g} / \mathrm{mL})$. A further electrophoresis was run in the presence of $0.1 \mu \mathrm{g} / \mathrm{mL}$ ethidium bromide, in order to separate the nicked DNA from the relaxed topoisomers.

\subsection{Oligonucleotide assays}

A 202-bp PvuII/HindIII fragment of pSK DNA substrate $\left[{ }^{32} \mathrm{P}\right]-$ labeled at a single $3^{\prime}$-end, was prepared as described elsewhere [23]. Equal concentrations of LiTopIB were incubated with at least $1.5 \mu \mathrm{L}$ of DNA containing a minimum of $100,000 \mathrm{cpm}$ in $10 \mathrm{mM}$ Tris- $\mathrm{HCl}$ buffer $\mathrm{pH} 7.5,5 \mathrm{mM} \mathrm{MgCl}_{2}, 5 \mathrm{mM}$ DTT, $0.1 \mathrm{mM}$ EDTA, $15 \mu \mathrm{g} / \mathrm{mL}$ bovine serum albumin, $50 \mathrm{mM} \mathrm{KCl}$, and different concentrations of camptothecin, topotecan, SN-38, gimatecan and camptothecin-N-oxide in 1\% DMSO. Following incubation for $2 \mathrm{~min}$ at room temperature, reactions were either stopped directly with $1 \%$ SDS or treated with $0.5 \mathrm{M} \mathrm{NaCl}$ for $1 \mathrm{~h}$ at $25^{\circ} \mathrm{C}$ to force LiTopIB religation and then stopped with $0.5 \%$ SDS at indicated times. The samples were heated at $75{ }^{\circ} \mathrm{C}$ for an extra 
15-min period, treated with proteinase $\mathrm{K}$ and subjected to doubleethanol precipitation prior to electrophoresis in a $16 \%$ polyacrylamide/7 M urea gel. Stabilized cleavage products were visualized with a PhosphorImager (Molecular Dynamics, Sunnyvale, CA).

\subsection{In situ sensitivity to camptothecin derivatives}

For drug-induced protein-DNA complex determination, L. infantum promastigotes, previously labeled for $24 \mathrm{~h}$ with $0.5 \mu \mathrm{Ci} / \mathrm{mL}\left[2-{ }^{14} \mathrm{C}\right]$ thymidine, were exposed to different concentrations of camptothecin and its derivatives for $30 \mathrm{~min}$, followed $\mathrm{SDS} / \mathrm{KCl}$ method as previously described [20]. All assays included solvent controls. DNA fragments formation, as a percentage of total labeled DNA, was calculated as follows: [(dpm in $\mathrm{SDS} / \mathrm{KCl}$ drug $-\mathrm{dpm}$ in $\mathrm{SDS} / \mathrm{KCl}$ solvent $) /(\mathrm{dpm}$ total incorporation $)] \times 100$. Each experiment was run at least in triplicate. For each drug the concentration causing $50 \%$ of DNA to be cleaved $\left(\mathrm{CC}_{50}\right)$ was calculated from dose/response curves.

\section{Results}

\subsection{Leishmanicidal effect of camptothecin and analogues}

We have analyzed the effect of the specific TopIB inhibitors outlined in Fig. 1 on the proliferation rate of $L$. infantum-IFR1.4 promastigotes and amastigotes. Table 1 shows the $\mathrm{IC}_{50}$ values obtained from dose-response plots, based on the percentage of infrared fluorescence signal at $708 \mathrm{~nm}$, obtained for free-living promastigotes and amastigote-infected splenocytes, exposed for $48 \mathrm{~h}$ to several concentrations of the tested compounds in comparison to untreated controls. The $\mathrm{IC}_{50}$ value obtained with miltefosine (a leishmanicidal alkylphospholipid) is also reported in Table as positive control. No differences in drug sensitivities are found between the IFR1.4-transfected strain and the wild-type (data not shown). Gimatecan and camptothecin are the most powerful compounds in killing promastigotes with $\mathrm{IC}_{50}$ values near $1 \mu \mathrm{M}$. The water-soluble derivative topotecan and SN-38 are less effective, but both have $\mathrm{IC}_{50}$ values lower than the positive-control miltefosine, that is more effective than camptothecin-N-oxide and irinotecan. The table also shows the $\mathrm{IC}_{50}$ value obtained for the amastigote-infected splenocytes. Gimatecan is the most effective one, having $\mathrm{IC}_{50}$ value on the nanomolar range, followed by camptothecin, $\mathrm{SN}-38$ and topotecan. Camptothecin-N-oxide and miltefosine are the weakest compounds in killing amastigotes working in the lower micromolar range. Irinotecan does not show a significative leishmanicidal effect likely due to its pro-drug nature.

The leishmanicidal effect of these compounds has been validated checking their potential toxicity on mammalian cells. For this purpose, freshly isolated splenocytes, from uninfected $\mathrm{BALB} / \mathrm{c}$ mice, have been exposed to different drug concentrations for $48 \mathrm{~h}$ and the percentage of living cells has been fluorimetrically determined with the Alamar Blue staining technique. The selective

A

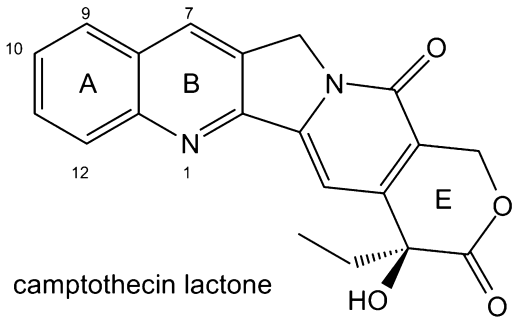<smiles>CCCCCCCOc1ccc2n(c1=O)Cc1cc3ccccc3nc1-2</smiles>

B<smiles>Cc1nc2cccc(O)c2cc1CN(C)C</smiles><smiles>CC1=Nc2ccccc2/C1=C\O/N=C\C(C)(C)C</smiles>

topotecan

gimatecan<smiles></smiles>

C

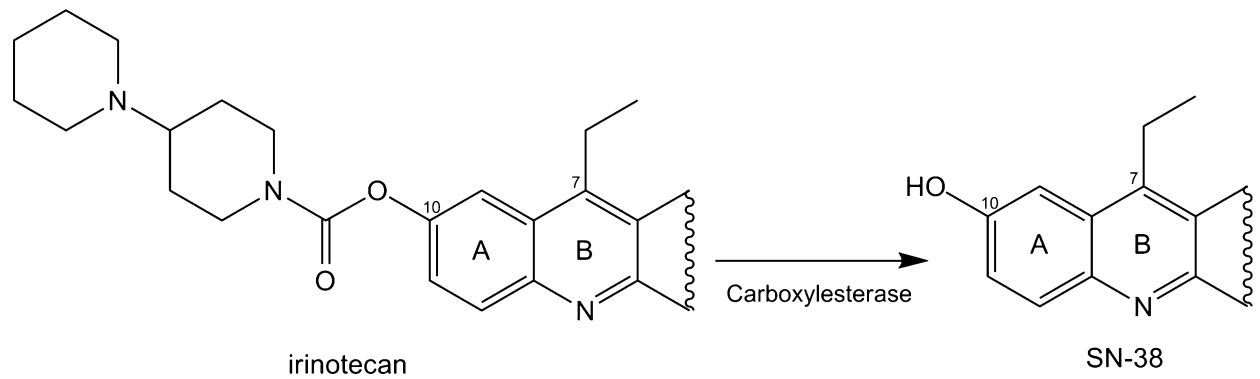

Fig. 1. Chemical structures of the camptothecin derivatives used in the study. (A) Lactone/carboxylate equilibrium of the camptothecin E-ring; (B) different moieties substituting the A and B rings of topotecan, gimatecan and camptothecin-N-oxide; (C) enzymatic hydrolysis of the prodrug irinotecan to the active compound SN-38. 
Table 1

$\mathrm{IC}_{50}$ calculation after a 48 -h period of exposure to the selected compounds of $L$. infantum promastigotes, ex vivo infected splenocytes and uninfected splenocytes. ${ }^{\mathrm{a}}$

\begin{tabular}{|c|c|c|c|c|}
\hline \multirow[t]{2}{*}{ Drug } & \multicolumn{4}{|l|}{$\mathrm{IC}_{50}$ for $^{\mathrm{b}}:$} \\
\hline & L. infantum promastigotes $(\mu \mathrm{M})^{\mathrm{c}}$ & Infecting amastigotes $(\mu \mathrm{M})^{\mathrm{c}}$ & Uninfected splenocyte culture $(\mu \mathrm{M})^{\mathrm{d}}$ & $\overline{\mathrm{SI}_{48}{ }^{\mathrm{e}}}$ \\
\hline Miltefosine & $25.15 \pm 2.35$ & $8.7 \pm 0.07$ & $504.1 \pm 7.0$ & 57.9 \\
\hline Camptothecin & $1.12 \pm 0.13$ & $0.03 \pm 0.01$ & $0.62 \pm 0.13$ & 20.7 \\
\hline Topotecan & $10.86 \pm 1.64$ & $0.16 \pm 0.05$ & $4.96 \pm 0.95$ & 31.0 \\
\hline Gimatecan & $1.73 \pm 0.10$ & $0.001 \pm 0.000$ & $0.21 \pm 0.00$ & 175 \\
\hline Camptothecin-N-oxide & $90.02 \pm 1.20$ & $1.48 \pm 0.54$ & $3.95 \pm 1.55$ & 2.7 \\
\hline $\mathrm{SN}-38$ & $12.20 \pm 2.11$ & $0.05 \pm 0.03$ & $0.54 \pm 0.08$ & 9.8 \\
\hline Irinotecan & $>200$ & $>100$ & $>200$ & ND \\
\hline
\end{tabular}

$\mathrm{ND}=$ no determined.

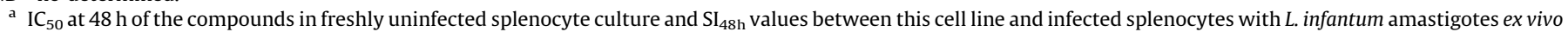

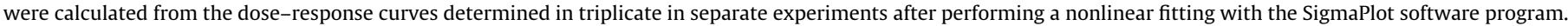

b Mean \pm SD.

c The viability of both L. infantum IFP1.4-promastigotes and infecting IFP1.4-amastigotes was assessed registering their infrared-fluorescence emission at 708 nm in an Odyssey (Li-Cor).

$\mathrm{d}$ The viability of uninfected splenocyte culture was assessed by using the Alamar Blue staining method on drug-exposed splenocytes derived from uninfected mice.

e Selectivity index; $\mathrm{SI}_{48 \mathrm{~h}}$, $\mathrm{IC}_{50}$ for uninfected splenocyte culture/ $/ \mathrm{IC}_{50}$ for amastigotes.

index $\left(\mathrm{SI}_{48 \mathrm{~h}}\right)$, calculated as the $\mathrm{IC}_{50}$ ratio of the uninfected and $L$. infantum-IFR1.4 infected splenocytes, reported in Table 1, shows that gimatecan is the safest compound with a $\mathrm{SI}_{48 \mathrm{~h}}$ value three fold higher than miltefosine and significantly higher than the other tested compounds.

\subsection{In situ formation of cleavable complexes}

The formation of enzyme-DNA adducts, in promastigotes exposed to camptothecin analogues, has been evaluated by protein precipitation with SDS. L. infantum promastigotes, grown in the presence of $\left[2-{ }^{14} \mathrm{C}\right]$-thymidine, have been exposed to increasing drugs concentrations over a period of $30 \mathrm{~min}$. The percentage of labeled $\mathrm{SDS} / \mathrm{KCl}$ precipitable complexes with respect to total labeled DNA has been determined using camptothecin as reference drug (Fig. 2A). Gimatecan displays the maximum DNA-cleaving potency $\left(\mathrm{CC}_{50}=0.02 \mu \mathrm{M}\right)$ since a gimatecan concentration of
$0.3 \mu \mathrm{M}$ is enough to obtain $80 \%$ of cleaved DNA (Fig. 2C). A camptothecin or topotecan concentration of 1 and $10 \mu \mathrm{M}$ respectively is needed to obtain a comparable DNA breakage percentage (Fig. 2A and B). Camptothecin-N-oxide reaches the same percentage at a concentration of $90 \mu \mathrm{M}$ (Fig. 2D), whilst in the case of SN-38 the maximum concentration of cleaved DNA is $50 \%$ even at a concentration of $90 \mu \mathrm{M}$ (Fig. $2 \mathrm{E}$ ).

\subsection{LiTopIB inhibition by camptothecin and derivatives}

The effect of the different compounds on the relaxation activity of LiTopIB has been monitored over time incubating $1 \mathrm{U}$ of LiTopIB with $75 \mu \mathrm{M}$ of each derivative in the presence of $0.5 \mu \mathrm{g}$ of $37^{\circ} \mathrm{C}$ pre-warmed supercoiled pSK DNA. Aliquots have been then taken at different time points, ranging from 0.2 to $15 \mathrm{~min}$. As shown in Fig. 3A, in absence of the drug, the supercoiled substrate is fully processed after $0.2 \mathrm{~min}$. Camptothecin and SN-38 inhibit the
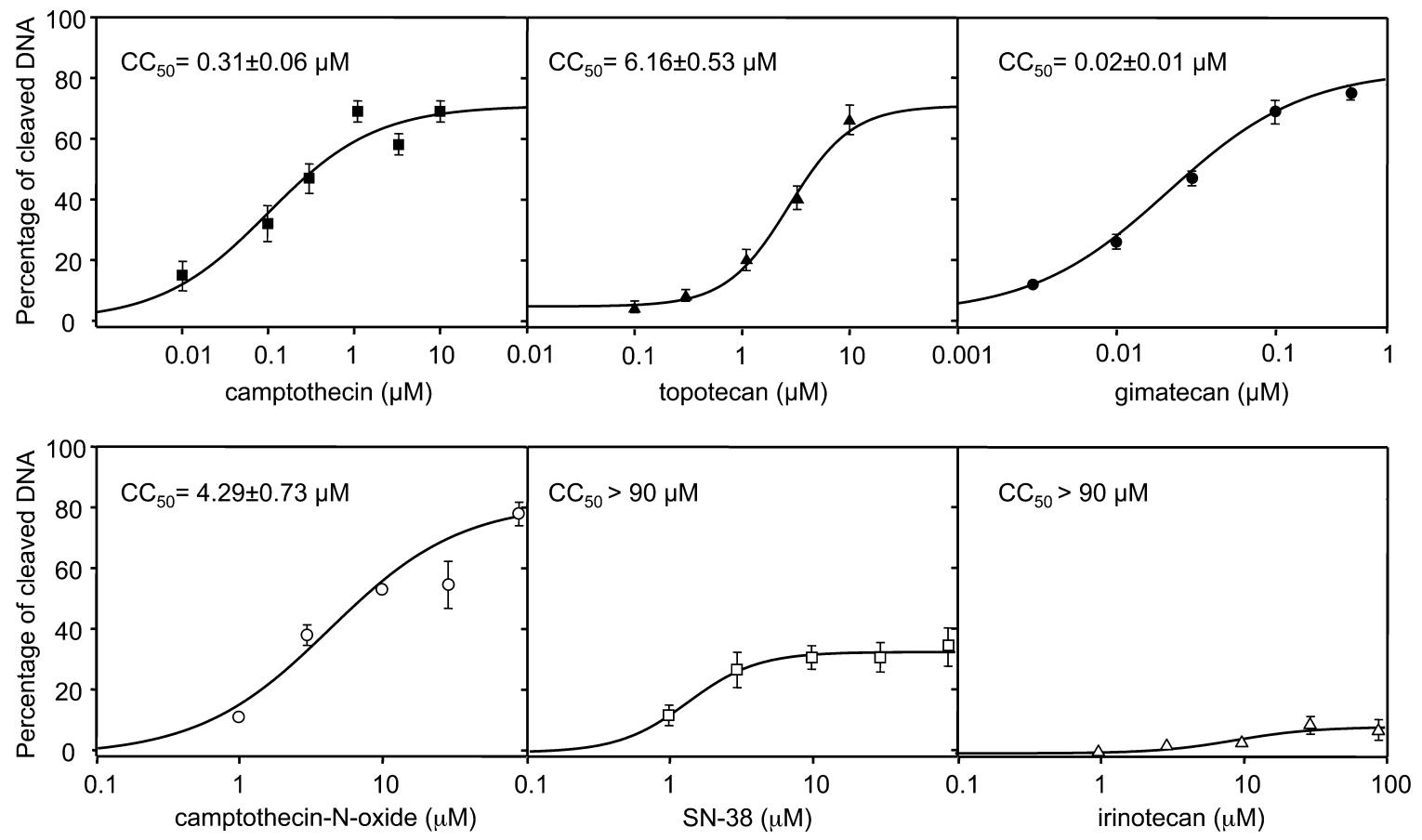

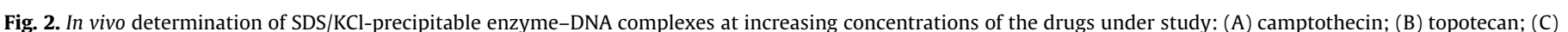

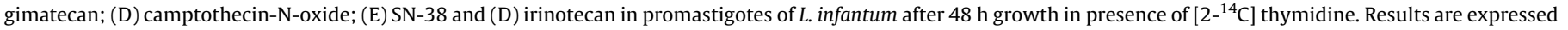
as mean \pm SE of at least three different experiments by duplicate. 
A

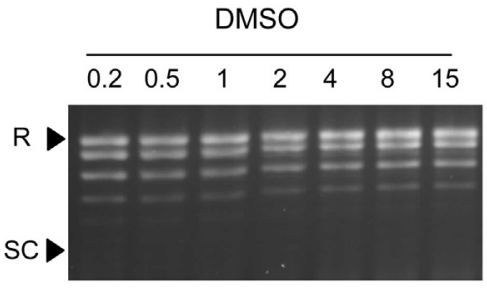

topotecan

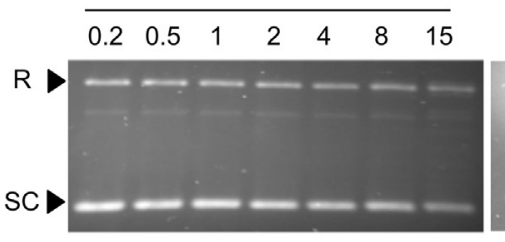

camptothecin

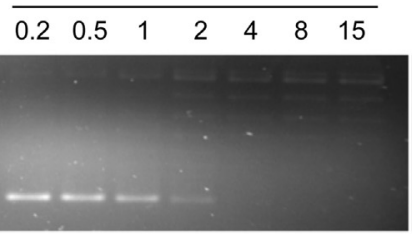

gimatecan

\begin{tabular}{lllllll}
\hline 0.2 & 0.5 & 1 & 2 & 4 & 8 & 15
\end{tabular}

camptothecin-N-oxide
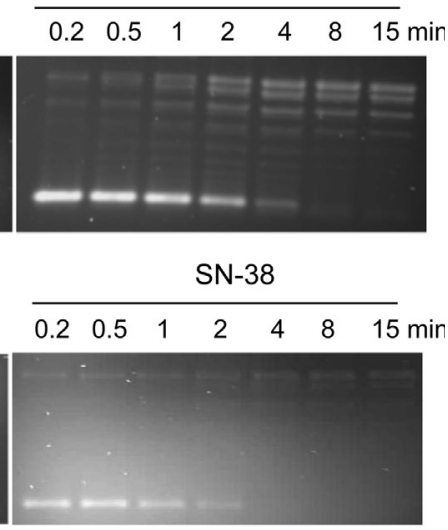

в

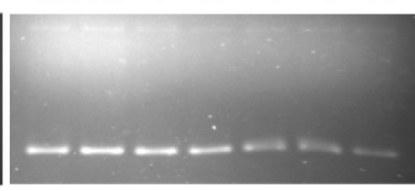

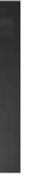

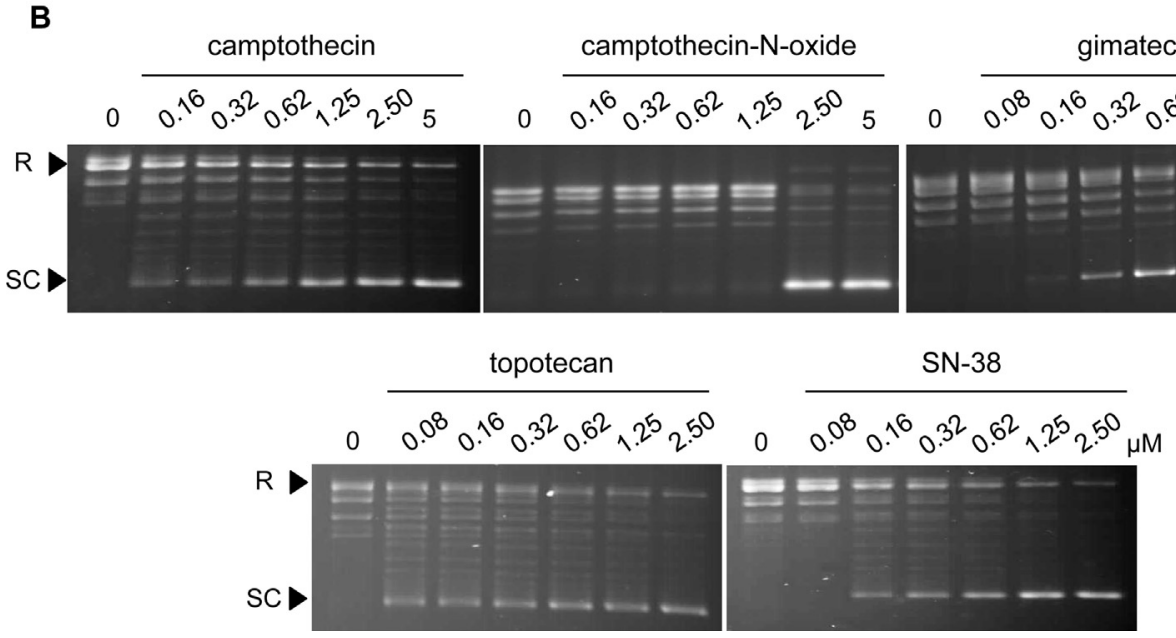

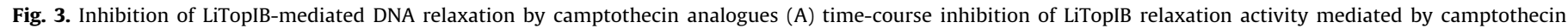

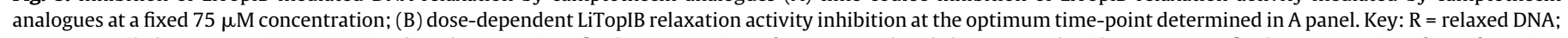

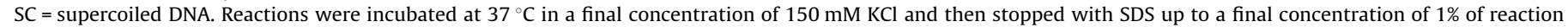
volume. Products were resolved in a $1 \%$ agarose gel and visualized by ethidium bromide staining. The results are representative of three independent trials.

relaxation of supercoiled DNA up to 2 min, camptothecin-N-oxide up to $4 \mathrm{~min}$, whilst gimatecan or topotecan are the most efficient ones preventing the relaxation activity of the enzyme up to $15 \mathrm{~min}$.

The inhibitory potency of the camptothecin derivatives on the relaxation activity of recombinant LiTopIB was also assessed after $30 \mathrm{sec}$ as a function of drug concentrations (Fig. 3B). Topotecan, camptothecin, gimatecan and SN38 have a comparable efficacy whilst larger camptothecin-N-oxide concentrations are required to have the same level of inhibition (Fig. 3B).

\subsection{Camptothecin derivatives poison LiTopIB}

A cleavage-religation equilibrium assay has been carried out in order to assess the cleavage stabilization nature of these drugs as TopIB poisons. These compounds are expected to act stabilizing the cleavable complexes generated by the nicking action of the enzyme. Once the enzyme is attached to DNA and cuts one of its strands, camptothecin stabilizes the LiTopIB-DNA complex and hinders the religation of the nicked DNA [10]. A PvuII/HindIII fragment of pSK DNA has been incubated with $100 \mathrm{U}$ of LiTopIB in presence of different drugs concentrations $(0.1,1,10$ and $100 \mu \mathrm{M})$. The first lane of Fig. 4 shows that in absence of the drugs no signals of the cleaved oligo are observed, indicating that the religated/ uncleaved $(\mathrm{R} / \mathrm{U})$ equilibrium is shifted towards religation. In presence of $\mathrm{SN}-38$, topotecan and gimatecan the equilibrium is shifted towards cleavage, since several cleaved bands (CL1, CL2 and CL3) are appearing due to the stabilization of the cleavable complexes. Gimatecan is the most powerful compound, since it stabilizes the enzyme-DNA complexes at concentrations of $0.1 \mu \mathrm{M}$. Camptothecin and $\mathrm{SN}-38$ require a concentration 10 -fold higher, whereas topotecan a 100-fold higher concentration to reproduce comparable effects. It is interesting to notice that topotecan is not able to trap the CL2 cleavable complex, likely due to a low residence time of the drug in this site or to a different cleavage pattern for topotecan in which CL2 is not a preferred site [24].

Fig. 5 shows a cleavage complex reversal assay comparing the stability of both LiTopIB-camptothecin-DNA and LiTopIB-gimatecan-DNA ternary complexes. The reversal of the LiTopIB cleavable complexes is much slower for gimatecan than for camptothecin. The effect of camptothecin persists for two minutes, whilst the gimatecan-stabilized complex can be detected up to $15 \mathrm{~min}$. The long persistence time of gimatecan on the DNA cleaved site provides an explanation to its greater potency in inducing cell death. 


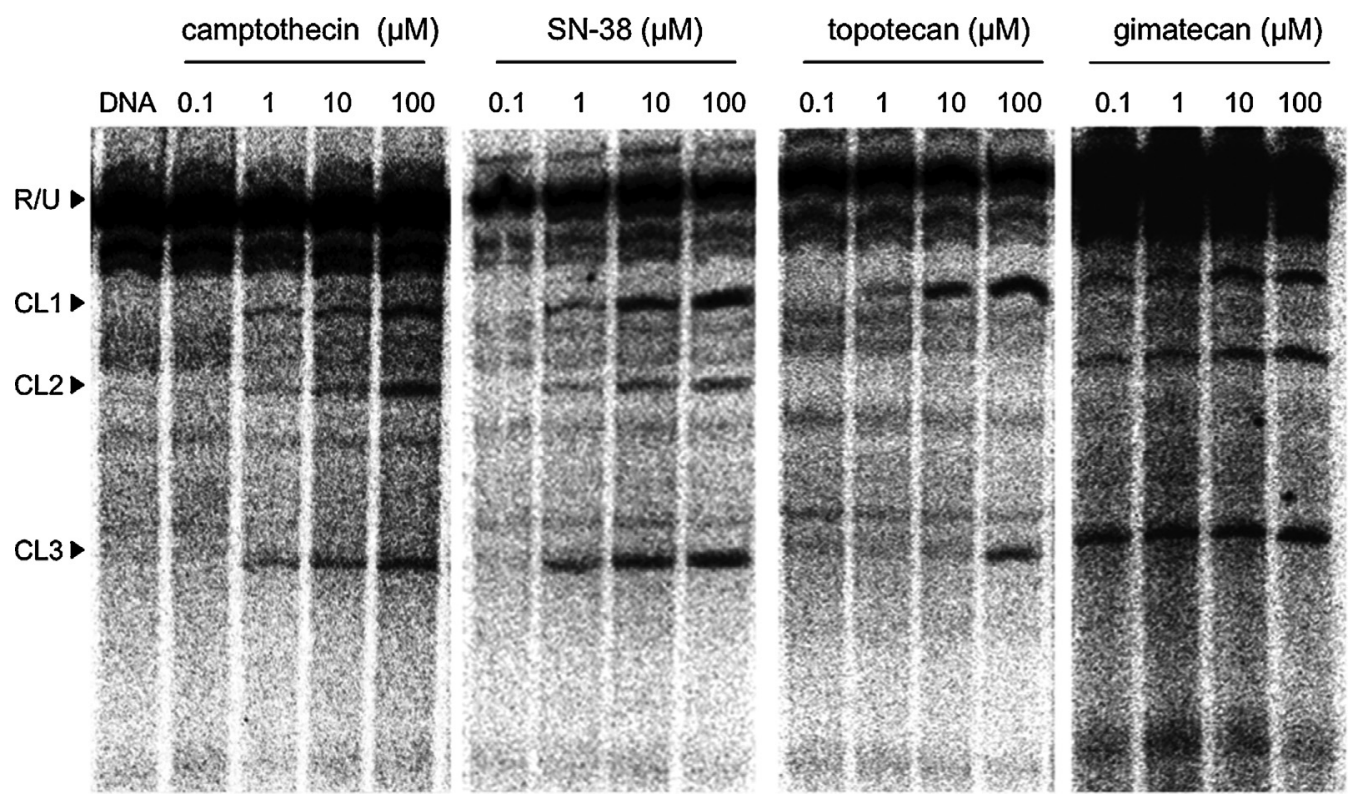

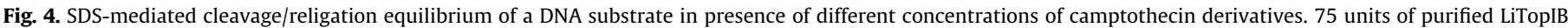

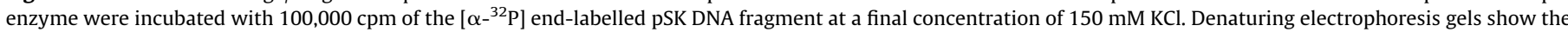

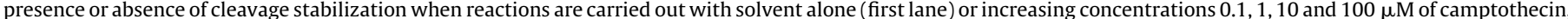

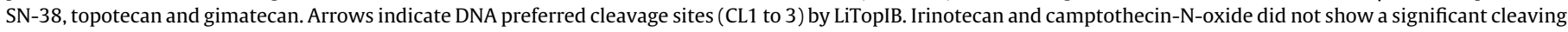
pattern at any concentration tested. The results are representative of three independent trials.

\section{Discussion}

One of the most problematic aspects of leishmaniases is the fast emergence of resistant strains against conventional drugs, which hinders the treatment and consequently, constant development of new therapeutic resources is required. In the present study, we have shown that gimatecan is a powerful growth inhibitor of L. infantum promastigotes that is even more lethal for its

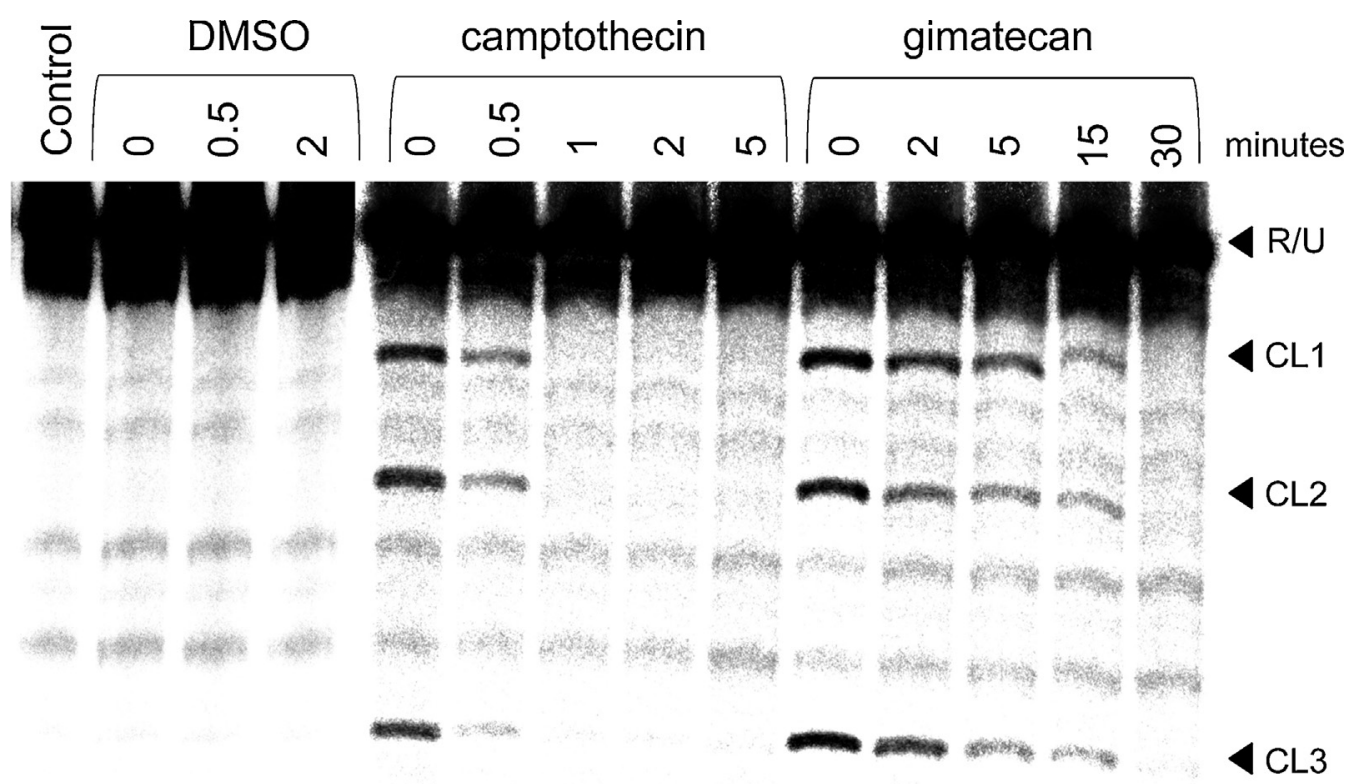

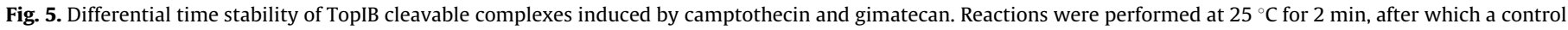
was taken (time 0 ) and $0.35 \mathrm{M} \mathrm{NaCl}$ was added. Times above each lane, aliquots were taken after $\mathrm{NaCl}$ addition and stopped by adding $0.5 \%$ SDS. 
intracellular form (amastigote) (Table 1 ). In addition, gimatecan is also shown to be a potent LiTopIB-poison.

In vitro results show that the relaxation activity of $L$. infantum DNA topoisomerase IB is inhibited by all the camptothecin derivatives, with the exception of camptothecin- $\mathrm{N}$-oxide and irinotecan, within the nanomolar range (Fig. 2B), suggesting that this enzyme is the potential target in camptothecin-treated Leishmania parasites. Gimatecan stabilizes the cleavable complexes at a concentration 10-fold lower than camptothecin, and of any other camptothecin derivatives (Fig. 4). Moreover the gimatecan-stabilized complexes are slowly reverted in comparison with the ones stabilized by camptothecin (Fig. 5). This fact may explain the enhanced leishmanicidal effect of gimatecan, since drug-induced DNA damage is directly proportional to the lifespan of the ternary complex. The slow reversal of the gimatecan-induced cleavable complexes is likely due to its 7-t-butoxyiminomethyl substitution, since this position has been shown to be important in other 7-modified camptothecin derivatives [25]. The long residence time of the gimatecan stabilized ternary complexes, is also in agreement with the long time that the LiTopIB relaxation activity remains hindered by this drug (Fig. 3A) and the greater potency of gimatecan in inducing $\mathrm{SDS} / \mathrm{KCl}$-precipitable DNA-topoisomerase complexes in vivo (Fig. 2).

The leishmanicidal activity of the camptothecin derivatives has been validated on a model of mouse splenocytes infected with a $L$. infantum strain expressing IFP1.4, which permits to study the compounds under conditions that resemble those found in the animal, including the presence of the complete range of immune host cells, infected macrophages and fibroblasts [20]. For all the studied derivatives the sensitivity of the amastigote form is much higher than that of free-living promastigotes (Table 1). This is not an unexpected result since many drugs with different intracellular targets have similar behavior [26]. However, irinotecan does not have leishmanicidal effect (up to $100 \mu \mathrm{M}$ ) in the splenocytes, suggesting that this compound is not metabolically hydrolyzed to $\mathrm{SN}-38$ within the splenic explants.

A remarkable finding is the extraordinary power of gimatecan in all trials conducted both in vitro and ex vivo. This drug has a therapeutic selectivity index above 170 , three times higher than miltefosine that is clinically used for the treatment of leishmaniasis (Table 1). Furthermore, gimatecan presents a series of added values, which must be taken into consideration, as they substantially improve the therapeutic index obtained for this drug and make it interesting for the treatment of visceral leishmaniasis: (i) after oral administration the highest tissue levels are found in liver and spleen [27]; (ii) the percentage of active lactone form in plasma is 80 to $100 \%$, much higher than those of its analogues, topotecan, irinotecan and SN-38 estimated at ca. $20 \%$ for each [28,29]; (iii) a half-life of over $76.5 \mathrm{~h}$, maintaining significant concentrations in plasma 7 days after the dose was given [28]; (iv) Zhu et al. [28] have shown in cancer patients that after weekly administration of oral gimatecan at $1.2 \mathrm{mg} / \mathrm{kg}$ concentration for 3 weeks the gimatecan is tolerated and has favorable pharmacokinetic properties. Miltefosine, despite its drug safety, has a less desirable dosage regimen that involves the administration of $1.76 \mathrm{mg} / \mathrm{kg} / \mathrm{d}$ for 28 days for an effective oral treatment of this cutaneous disease, resulting in difficulty of adherence to treatment of infected people in developing countries [30]; (v) unlike other camptothecins the pharmacokinetics of the compound appears to be more favorable in humans than in mice [29]; ( vi) it has recently been shown that gimatecan is not affected by multidrug resistant protein 1 (MDR-1) efflux in tumor cell lines (responsible for resistance to camptothecin), which have an orthologous protein-coding gene in Leishmania [15].
In conclusion, the present study indicates that all the here studied camptothecins with the exception of camptothecin-N-oxide, are Leishmania topoisomerase IB poisons in the low micromolar range, although gimatecan is the most efficient one and its excellent selectivity index suggest that this compound may be exploited as a potential drug candidate against visceral leishmaniasis.

\section{Conflict of interest statement}

The authors declare that there are no conflicts of interest.

\section{Acknowledgements}

This research was supported by Ministerio de Ciencia y Tecnología (grants AGL2009-11935/GAN and AGL2010-16078/ GAN), Instituto de Salud Carlos III (grants PI09/0448, PI12/00104 and the Network of Tropical Diseases RICET) and Junta de Castilla y León (grant Gr238) and AIRC (grant no. 10121). RAV, CFP and ECA are pre-doctoral fellows granted by Instituto de Salud Carlos III, JCyL-ESF and University of León, respectively. CP was supported by a Juan de la Cierva programme (JCI-2009-05444) of the Ministry of Economy and Competence (Spain). Authors wish to thank to Sigma-tau (Italy) for providing the gimatecan used in this study.

\section{References}

[1] Cruz I, Nieto J, Moreno J, Cañavate C, Desjeux P, Alvar J. Leishmania/HIV co-infections in the second decade. Indian J Med Res 2006;123:357-88.

[2] Berman J. Clinical status of agents being developed for leishmaniasis. Expert Opin Investig Drugs 2005;14:1337-46.

[3] Croft SL, Olliaro P. Leishmaniasis chemotherapy - challenges and opportunities. Clin Microbiol Infect 2011;17:1478-83.

[4] Champoux JJ. DNA topoisomerases: structure, function, and mechanism. Annu Rev Biochem 2001;70:369-413.

[5] Pommier Y. Topoisomerase I inhibitors: camptothecins and beyond. Nat Rev Cancer 2006;6:789-802.

[6] Villa H, Otero-Marcos AR, Reguera RM, Balaña-Fouce R, García-Estrada C, Pérez-Pertejo Y, et al. A novel active DNA topoisomerase I in Leishmania donovani. J Biol Chem 2003;278:3521-6.

[7] Bodley AL, Chakraborty AK, Xie S, Burri C, Shapiro TA. An unusual type IB topoisomerase from African trypanosomes. Proc Natl Acad Sci USA 2003;100:7539-44.

[8] Balaña-Fouce R, Redondo CM, Pérez-Pertejo Y, Díaz-González R, Reguera RM. Targeting atypical trypanosomatid DNA topoisomerase I. Drug Discov Today 2006;11:733-40.

[9] Díaz-González R, Pérez-Pertejo Y, Ordóñez D, Balaña-Fouce R, Reguera RM. Deletion study of DNA topoisomerase IB from Leishmania donovani: searching for a minimal functional heterodimer. PLoS ONE 2007;2:e1177.

[10] Prada CF, Alvarez-Velilla R, Diaz-González R, Prieto C, Pérez-Pertejo Y, BalañaFouce $\mathrm{R}$, et al. A pentapeptide signature motif plays a pivotal role in Leishmania DNA topoisomerase IB activity and camptothecin sensitivity. Biochim Biophys Acta 2012;1820:2062-71.

[11] Hertzberg RP, Caranfa MJ, Hecht SM. On the mechanism of topoisomerase I inhibition by camptothecin: evidence for binding to an enzyme-DNA complex. Biochemistry 1989;28:4629-38.

[12] Staker BL, Hjerrild K, Feese MD, Behnke CA, Burgin Jr AB, Stewart L. The mechanism of topoisomerase I poisoning by a camptothecin analog. Proc Natl Acad Sci USA 2002;99:15387-92.

[13] Luzzio MJ, Besterman JM, Emerson DL, Evans MG, Lackey K, Leitner PL, et al. Synthesis and antitumor activity of novel water soluble derivatives of camptothecin as specific inhibitors of topoisomerase I. J Med Chem 1995;38:395-401.

[14] Antony S, Agama KK, Miao ZH, Hollingshead M, Holbeck SL, Wright MH, et al. Bisindenoisoquinoline bis-1,3-\{(5,6-dihydro-5,11-diketo-11H-indeno[1,2c]isoquinoline)-6-propylamino\}propane bis(trifluoroacetate) (NSC 727357), a DNA intercalator and topoisomerase inhibitor with antitumor activity. Mol Pharmacol 2006;70:1109-20.

[15] Teicher AB. Next generation topoisomerase I inhibitors: rationale and biomarker strategies. Biochem Pharmacol 2008;75:1262-71.

[16] Lee MP, Brown SD, Chen A, Hsieh TS. DNA topoisomerase I is essential in Drosophila melanogaster. Proc Natl Acad Sci USA 1993;90:6656-60.

[17] Balaña-Fouce R, Garcia-Estrada C, Perez-Pertejo Y, Reguera RM. Gene disruption of the DNA topoisomerase IB small subunit induces a non-viable phenotype in the hemoflagellate Leishmania major. BMC Microbiol 2008;8:113.

[18] Bakshi RP, Shapiro TA. RNA interference of Trypanosoma brucei topoisomerase IB: both subunits are essential. Mol Biochem Parasitol 2004;136:249-55.

[19] Reguera RM, Redondo CM, Gutierrez de Prado R, Pérez-Pertejo Y, Balaña-Fouce R. DNA topoisomerase I from parasitic protozoa: a potential target for chemotherapy. Biochim Biophys Acta 2006;1759:117-31. 
[20] Balaña-Fouce R, Prada CF, Requena JM, Cushman M, Pommier Y, ÁlvarezVelilla R, et al. Indotecan (LMP400) and AM13-55: two novel indenoisoquinolines show potential for treating visceral leishmaniasis. Antimicrob Agents Chemother 2012;56:5264-70.

[21] Shu X, Royant A, Lin MZ, Aguilera TA, Lev-Ram V, Steinbach PA, et al. Mammalian expression of infrared fluorescent proteins engineered from a bacterial phytochrome. Science 2009;324:804-7.

[22] Osorio Y, Travi BL, Rensio AR, Peniche AG, Melby PC. Identification of small molecule lead compounds for visceral leishmaniasis using novel ex vivo splenic explant model system. Plos Negl Trop Dis 2011;5:e962.

[23] Dexheimer TS, Pommier Y. DNA cleavage assay for the identification of topoisomerase I inhibitors. Nat Protoc 2008;3:1736-49.

[24] Tanizawa A, Fujimori A, Fujimori Y, Pommier Y. Comparison of topoisomerase I inhibition, DNA damage, and cytotoxicity of camptothecin derivatives presently in clinical trials. J Natl Cancer Inst 1994;86:836-42.

[25] Valenti M, Nieves-Neira W, Kohlhagen G, Kohn KW, Wall ME, Wani MC, et al. Novel 7-alkyl methylenedioxy-camptothecin derivatives exhibit increased cytotoxicity and induce persistent cleavable complexes both with purified mammalian topoisomerase I and in human colon carcinoma SW620 cells. Mol Pharmacol 1997;52:82-7.

[26] Coombs GH, Hart DT, Capaldo J. Leishmania mexicana: drug sensitivities of promastigotes and transforming amastigotes. J Antimicrob Chemother 1983;11:151-62.

[27] Dallavalle S, Delsoldato T, Ferrari A, Merlini L, Penco S, Carenini N, et al. Novel 7-substituted camptothecins with potent antitumor activity. J Med Chem 2000;43:3963-9.

[28] Zhu AX, Ready N, Clark JW, Safran H, Amato A, Salem N, et al. Phase I and pharmacokinetic study of gimatecan given orally once a week for 3 of 4 weeks in patients with advanced solid tumors. Clin Cancer Res 2009;15: 374-81.

[29] Burke TG, Munshi CB, Mi Z, Jiang Y. The important role of albumin in determining the relative human blood stabilities of the camptothecin anticancer drugs. J Pharm Sci 1995;84:518-9.

[30] Dorlo TP, van Thiel PP, Huitema AD, Keizer RJ, de Vries HJ, Beijnen JH, et al. Pharmacokinetics of miltefosine in Old World cutaneous leishmaniasis patients. Antimicrob Agents Chemother 2008;52:2855-60. 

"Appraisal of a Leishmania major strain stably expressing mCherry fluorescent protein for both in vitro and in vivo studies of potential drugs and vaccine against cutaneous leishmaniasis". Calvo-Álvarez E., Guerrero NA., Alvarez-Velilla R., Prada CF., Requena JM., Punzón C., Llamas MÁ., Arévalo FJ., Rivas L., Fresno M., Pérez-Pertejo Y., Balaña-Fouce R., Reguera RM. (2012) PLoS Negl Trop Dis. 


\title{
Appraisal of a Leishmania major Strain Stably Expressing mCherry Fluorescent Protein for Both In Vitro and In Vivo Studies of Potential Drugs and Vaccine against Cutaneous Leishmaniasis
}

\author{
Estefania Calvo-Álvarez ${ }^{19}$, Nestor Adrian Guerrero ${ }^{29}$, Raquel Álvarez-Velilla ${ }^{1}$, Christopher \\ Fernández Prada ${ }^{1}$, Jose María Requena ${ }^{2}$, Carmen Punzón ${ }^{3}$, Miguel Ángel Llamas ${ }^{3}$, Francisco J. Arévalo ${ }^{3}$, \\ Luis Rivas ${ }^{4}$, Manuel Fresno ${ }^{2,3}$, Yolanda Pérez-Pertejo ${ }^{1}$, Rafael Balaña-Fouce ${ }^{1 *}$, Rosa M. Reguera ${ }^{1}$ \\ 1 Departamento de Ciencias Biomédicas, Universidad de León, León, Spain, 2 Centro de Biología Molecular "Severo Ochoa", Universidad Autónoma de Madrid, Madrid, \\ Spain, 3 Diomune, Parque Cientifico de Madrid, Madrid, Spain, 4 Centro de Investigaciones Biológicas, Madrid, Spain
}

\begin{abstract}
Background: Leishmania major cutaneous leishmaniasis is an infectious zoonotic disease. It is produced by a digenetic parasite, which resides in the phagolysosomal compartment of different mammalian macrophage populations. There is an urgent need to develop new therapies (drugs) against this neglected disease that hits developing countries. The main goal of this work is to establish an easier and cheaper tool of choice for real-time monitoring of the establishment and progression of this pathology either in BALB/c mice or in vitro assays. To validate this new technique we vaccinated mice with an attenuated $\Delta$ hsp70-II strain of Leishmania to assess protection against this disease.

Methodology: We engineered a transgenic L. major strain expressing the mCherry red-fluorescent protein for real-time monitoring of the parasitic load. This is achieved via measurement of fluorescence emission, allowing a weekly record of the footpads over eight weeks after the inoculation of BALB/c mice.

Results: In vitro results show a linear correlation between the number of parasites and fluorescence emission over a range of four logs. The minimum number of parasites (amastigote isolated from lesion) detected by their fluorescent phenotype was 10,000 . The effect of antileishmanial drugs against $m C h e r r y+L$. major infecting peritoneal macrophages were evaluated by direct assay of fluorescence emission, with $\mathrm{IC}_{50}$ values of $0.12,0.56$ and $9.20 \mu \mathrm{M}$ for amphotericin $\mathrm{B}$, miltefosine and paromomycin, respectively. An experimental vaccination trial based on the protection conferred by an attenuated $\Delta$ hsp70-II mutant of Leishmania was used to validate the suitability of this technique in vivo.

Conclusions: A Leishmania major strain expressing mCherry red-fluorescent protein enables the monitoring of parasitic load via measurement of fluorescence emission. This approach allows a simpler, faster, non-invasive and cost-effective technique to assess the clinical progression of the infection after drug or vaccine therapy.
\end{abstract}

Citation: Calvo-Álvarez E, Guerrero NA, Álvarez-Velilla R, Prada CF, Requena JM, et al. (2012) Appraisal of a Leishmania major Strain Stably Expressing mCherry Fluorescent Protein for Both In Vitro and In Vivo Studies of Potential Drugs and Vaccine against Cutaneous Leishmaniasis. PLoS Negl Trop Dis 6(11): e1927. doi:10.1371/journal.pntd.0001927

Editor: Genevieve Milon, Institut Pasteur, France

Received April 30, 2012; Accepted October 16, 2012; Published November 29, 2012

Copyright: @ 2012 Calvo-Álvarez et al. This is an open-access article distributed under the terms of the Creative Commons Attribution License, which permits unrestricted use, distribution, and reproduction in any medium, provided the original author and source are credited.

Funding: This research was supported by Ministerio de Ciencia y Tecnología (grants AGL2010 16078/GAN), Instituto de Salud Carlos III (grant PI09/0448 and the Network of Tropical Diseases RICET RD06/0021/1004). RAV, CFP and ECA are pre-doctoral fellows granted by RICET (ISCIII), Junta de Castilla y León (ESF; European Social Founding) and University of León, respectively to RMR. Instituto de Salud Carlos III (Network of Tropical Disasese RICET RD06/0021/0016), Ministerio de Ciencia e Innovación (SAF2010-17833), ChagasEpiNet 223034 European Union Seventh Framework Programme and Fundación Ramón Areces to MF. Funding by ISCIII-RETIC RD06/0021/0008-FEDER to JMR and ISCIII-RETIC RD06/0021/0006-FEDER to LR is also acknowledged. The funders had no role in study design, data collection and analysis, decision to publish, or preparation of the manuscript.

Competing Interests: The authors have declared that no competing interests exist.

*E-mail: rbalf@unileon.es

9 These authors contributed equally to this work.

\section{Introduction}

Leishmania major is the main cause of cutaneous leishmaniasis (CL) in the Old World. Parasites are transmitted by Phlebotominae sandflies whilst blood feeding on infected mammalian hosts. CL is widely spread in the developing world, affecting people in 88 countries with 1.5 million new cases reported each year. CL usually produces ulcers on the exposed parts of the body that often leave disfiguring scars, which in turn, can cause serious social prejudice [1]

Conventional in vivo animal models for the study of parasite-host relationships involve large number of animals. These animals are required to be slaughtered at different time points in order to identify both anatomical distribution and parasite numbers in 


\section{Author Summary}

Leishmaniasis is a parasitic disease that is far from eradication. The lack of an efficacious vaccine and treatment failures are major factors in its intractable worldwide prevalence. A non-invasive imaging technique using genetically engineered parasites that expressed fluorescent proteins could give to researchers a quantitative and visual tool to characterize the parasite burden in experimental infections. In addition, it can be useful for determining the efficacy of candidate vaccines or drugs using High Throughput Screening methods that allow the testing of libraries of compounds in an automated 96-well plate format. Herein, we demonstrate that there is a good correlation between fluorescence emission and the parasite load, thus permitting the use of this output to monitor the progression of the disease. In order to validate this tool we have immunized mice prior the parasite challenge with a red-emitting parasite strain, confirming the scientific suitability of this approach as a valuable alternative model.

organs and tissues. Furthermore, this approach has some important limitations that must be overcome: i) post-mortem analysis of animals makes it impossible to track the space/time progression of the pathogen within the hosts; ii) spread of the pathogen to unexpected anatomic sites can remain undetected; iii) in order to achieve precise and relevant data, it is necessary to kill large numbers of animals. Recent real-time in-vivo imaging techniques with genetically modified pathogens represent a valuable complementary tool. They can be used for conventional studies of pathogenesis and therapy as long as the modified pathogen retains the virulence of the parental strain. Moreover, this has led to an increased number of reports concerning genetically modified parasites that express bioluminescent and/or fluorescent reporters. This was principally developed for in-vitro infection studies and to monitor diseases in living animals [2,3]. Bioluminescent pathogens expressing the sea pansy Renilla reniformis luciferase have been used in experimental murine infections of Toxoplasma gondii [4] as well as in the rodent malaria parasite Plasmodium berghei [5]. A recent study has allowed scientists to identify the liver stages of firefly luciferase-expressing parasites in living animals [6].

This approach has also been successfully implemented in trypanosomatids. Lang and co-workers showed that a luciferase expressing L. amazonensis strain was useful for rapid screening of drugs in infected macrophages [7]. Further studies used the same techniques with L. major [8], L. infantum [9] and in in-vivo murine experimental infections [7,10]. Besides, the use of Trypanosoma brucei expressing $R$. reniformis luc gene has permitted scientists to find unusual colonizing niches during the progression of African trypanosomiasis [11].

Fluorescent imaging offers several benefits: i) unlike lightemitting proteins, fluorescent reporters do not require specific substrates: ii) the fluorescence emitted is very stable over time and iii) this approach is useful when studying tissue harvested from infected animals since parasites can be individually identified [12].

The first transgenic Leishmania species expressing the green fluorescent protein (GFP) was reported by Beverley's group [13]. Episomally transfected Leishmania spp. with GFP or enhanced GFP (EGFP) have enhanced High Throughput Screening (HTS) methods in free-living promastigotes [14-17] and amastigotes [18-22]. However, only recently, the stable transfection of the EGFP reporter has been found suitable for both in vitro and in vivo infection studies [21-24]. Although native GFP produces signif- icant fluorescence and is extremely stable, the excitation maximum is close to the ultraviolet range, which can result in damaging living cells.

Red-fluorescence labelled parasites have been used to determine the early stages of CL pathogeny at the infection site (revised by Millington and co-workers [25]). By combining a L. major Red Fluorescent Protein 1 (RFP)-expressing strain and dynamic intravital microscopy, the site of sandfly bites has been identified in vivo in a mouse model. The study reveals an essential role for both neutrophils and dendritic cells that converge at localized sites of acute inflammation in the skin following pathogen deposition [26,27]. Using mCherry-L. infantum chagasi - responsible of visceral leishmaniasis in the New World - researchers have been able to report the recruitment of neutrophils and their role in nonulcerative forms of leishmaniasis [28]. In addition, to study the mechanism regulating dentritic cell recruitment and activation in susceptible BALB/c [29] and resistant C57BL/6 mice [30] DsRed labelled parasites were used

Fluorescent parasites have been used to explain some aspects of Leishmania biology. L. donovani lines stably expressing either EGFP or RFP have been used to identify hybrid parasites produced during the early development of the sandfly [31]. In addition, a $L$. major strain, which episomally expressed the DsRed protein, was used for quantifying the infectious dosage transmitted by a sandfly bite [32].

Based on the improved photostability as well as suitability for intravital imaging, mCherry was considered the best choice for our studies in comparison to other red fluorescent proteins [33]. mCherry is a protein derived from the coral Discosoma striata RFP. It has a maximum emission peak at $610 \mathrm{~nm}$ with a $587 \mathrm{~nm}$ excitation wavelength. Despite the fact that it is $50 \%$ less bright than EGFP, it is more photostable and it has higher tissue penetration [12]. Because of this, it is the best-suited choice in applications of single-molecule fluorescence or multicolour fluorescent imaging [34]. In this report we describe the use of a stably mCherry-transfected L. major strain as a valuable tool to both in vitro assays for drug screening and in vivo pre-clinical vaccine studies in real-time.

\section{Materials and Methods}

\section{Mice and parasites}

The animal research described in this manuscript complied with Spanish (Ley 32/2007) and European Union Legislation (2010/ 63/UE). The used protocols were approved by the Animal Care Committee of the Centro de Biología Molecular and Universidad Autónoma de Madrid (Spain).

Female BALB/c mice (6-8 week old) were purchased from Harlan Interfauna Iberica S.A. (Barcelona, Spain) and maintained in specific-pathogen-free facilities for this study.

L. major LV39c5 (RHO/SU/59/P) strain was used for generating mCherry transgenic promastigotes. Parasites were cultured at $26^{\circ} \mathrm{C}$ in M199 supplemented with $25 \mathrm{mM}$ HEPES $\mathrm{pH} 7.2, \quad 0.1 \mathrm{mM}$ adenine, $0.0005 \%$ (w/v) hemin, $2 \mu \mathrm{g} / \mathrm{ml}$ biopterin, $0.0001 \%(\mathrm{w} / \mathrm{v})$ biotin, $10 \%(\mathrm{v} / \mathrm{v})$ heat-inactivated foetal calf serum (FCS) and antibiotic cocktail $(50 \mathrm{U} / \mathrm{ml}$ penicillin, $50 \mu \mathrm{g} / \mathrm{ml}$ streptomycin). Attenuated $\Delta \mathrm{hsp} 70$-II (Ahsp70-II::NEO/ $\Delta h s p 70$-II::HYG), used as candidate vaccine [35], is a null mutant for the hsp70-type-II gene, generated by targeted deletion in $L$. infantum (MCAN/ES/96/BCN150) strain [36]. $\Delta$ hsp70-II promastigotes were grown in RPMI 1640 (Sigma-Aldrich) culture medium supplemented with $10 \%$ (v/v) FCS, $50 \mathrm{U} / \mathrm{ml}$ penicillin and $50 \mu \mathrm{g} / \mathrm{ml}$ streptomycin. 


\section{Generation of a mCherry+L. major strain}

The 711-bp mCherry coding region was amplified by PCR from pRSETb-mCherry vector, a kindly gift from Dr Roger Y. Tsien Departments of Pharmacology and Chemistry \& Biochemistry, UCSD (USA) - [37] with the primers RBF634 and RBF600 (Table 1). PGR product was cut with appropriate restriction enzymes and ligated into the $B g I I \mathrm{I}$ and $\mathcal{N}_{0} t \mathrm{I}$ sites of the pLEXSYhyg2 expression vector (Jena Bioscience GmbH, Germany). Parasites expressing mCherry Open Reading Frame (ORF) were obtained by transfection of $L$. major with the large SwaI targeting fragment derived from pLEXSY-mCherry by electroporation and subsequent plating on semisolid media containing $200 \mu \mathrm{g} / \mathrm{ml}$ hygromycin B (Sigma-Aldrich) as previously described [38]. Correct integration of mCherry ORF into the 18S rRNA locus of the resulting transgenic clones (mCherry+L. major) was confirmed by Southern blot and PCR amplification analyses, using the primers of Table 1. The fluorescent of stable-transfected mCherry clones was confirmed by both flow cytometry (BD FACSCantoII) and confocal microscopy (Nikon Eclipse TE2000E).

\section{In vitro infections and drug screening}

Starch-elicited peritoneal macrophages were recovered from $\mathrm{BALB} / \mathrm{c}$ mice and then $5 \times 10^{4}$ cells were plated on black 96 wells plates with clear bottom. Macrophages were infected at a ratio of five metacyclic promastigotes per macrophage. Metacyclic mCherry + L. major promastigotes were isolated from stationary cultures (4-5 days old) by Ficoll gradient centrifugation [39]. Briefly, $2 \mathrm{ml}$ of parasite suspension in M199 containing approximately $7 \times 10^{7}$ stationary-phase promastigotes were layered onto a discontinuous density gradient in a $15 \mathrm{ml}$ conical tube consisting of $2 \mathrm{ml}$ of $20 \%$ (w/v) Ficoll stock solution made in distilled water and $2 \mathrm{ml}$ of 10\% (w/v) Ficoll diluted in M199 medium.

Metacyclic parasites were opsonized with $4 \%(\mathrm{v} / \mathrm{v}) \mathrm{C} 5^{-}$mouse deficient serum (The Jackson Laboratory, USA) at $37^{\circ} \mathrm{C}$ for $30 \mathrm{~min}$ and resuspended in RPMI containing 10\% (v/v) FCS [40]. The infection was synchronized by centrifugation $(330 \times \mathrm{g}, 3 \mathrm{~min}$ at $4^{\circ} \mathrm{C}$ ) and infected macrophages were incubated at $37^{\circ} \mathrm{C}$ in a humidified $5 \% \quad \mathrm{CO}_{2}$ atmosphere [41]. Cells were washed extensively with phosphate buffer saline (PBS) to remove the free parasites and overlaid with fresh medium, which was replaced daily thereafter. After one day incubation, to allow differentiation into amastigotes, drugs (miltefosine, amphotericin B and paromo- mycin) were added to the appropriate wells in a threefold dilution series in RPMI (Sigma-Aldrich) with 10\% (v/v) FCS and cells were further incubated at $37^{\circ} \mathrm{C}$ for a further incubation of $72 \mathrm{~h}$. Plates were read in a fluorescence microplate reader (Synergy HT; BioTek) $\left(\lambda_{\mathrm{ex}}=587 \mathrm{~nm} ; \lambda_{\mathrm{em}}=610 \mathrm{~nm}\right)$.

\section{In vivo infections}

Metacyclic promastigotes were isolated from stationary cultures (4-5 days old) by negative selection with peanut agglutinin for mouse infections. Briefly, promastigotes were resuspended in PBS at $10^{8} \mathrm{cells} / \mathrm{ml}$, and peanut agglutinin (Vector laboratories) was added at $50 \mu \mathrm{g} / \mathrm{ml}$; the sample was incubated for $25 \mathrm{~min}$ at room temperature. After centrifugation at $200 \times \mathrm{g}$ for $10 \mathrm{~min}$, the supernatant contained the non-agglutinated metacyclic promastigotes [42].

The virulence of $L$. major parasites was maintained by passage in $\mathrm{BALB} / \mathrm{c}$ mice by injecting hind footpads with $10^{6}$ stationary-phase parasites. After 6-8 weeks, animals were euthanized and popliteal lymph nodes were dissected, mechanically dissociated, homogenized and filtered. L. major amastigotes were isolated from murine lymph nodes by passing the tissue through a wire mesh followed by disrupting the cells sequentially through $25 \mathrm{G}_{1 / 2}$ and $27 \mathrm{G}_{1 / 2}$ needles, and polycarbonate membrane filters with pore size of 8,5 and $3 \mu \mathrm{m}$ (Isopore, Millipore) [43]. Isolated amastigotes were transformed to promastigote forms by culturing at $26^{\circ} \mathrm{C}$ in Schneider's medium (Gibco, BRL, Grand Island, NY, USA) supplemented with $20 \%$ (v/v) FCS, $100 \mathrm{U} / \mathrm{ml}$ penicillin and $100 \mu \mathrm{g} / \mathrm{ml}$ streptomycin. For infections, amastigote-derived promastigotes with less than five passages in vitro were used.

$\mathrm{BALB} / \mathrm{c}$ mice were injected with several inocula $\left(10^{4}, 10^{5}\right.$ and $10^{6}$ promastigotes/mouse) during the setting up of the model. For protection studies mice were vaccinated intravenously (tail-vein injection) with the $\Delta$ hsp 70 -II mutant strain $\left(2 \times 10^{7}\right.$ promastigotes/ mouse) [35], or injection of PBS (control group), and four weeks post-vaccination, were infected with $2 \times 10^{5}$ mCherry+L. major metacyclic promastigotes. The infections were performed by injection of parasites in $50 \mu \mathrm{l}$ PBS in the right hind footpads. The growth of the lesion was monitored by fluorescence emission detection (see below). The contralateral footpad of each animal represented the negative control value. Footpad swelling was measured using a Vernier calliper and data were represented as the increment of the lesion size respect to the not infected footpad.

Table 1. Oligonucleotides used in this work.

\begin{tabular}{|c|c|c|c|c|}
\hline \multicolumn{2}{|l|}{ Oligo No. } & \multirow{2}{*}{$\begin{array}{l}\text { Sequence }^{\mathbf{a}, \mathbf{b}} \\
\text { ccgCTCGAGgaAGATCTCCACCATGGTGAGCAAGGGCG }\end{array}$} & \multicolumn{2}{|l|}{ Purposed ${ }^{c}$} \\
\hline RBF 634 & $(7)$ & & mCherry & $\mathrm{F}$ \\
\hline RBF 600 & $(8)$ & ataagaatGCGGCCGCTTACTTGTACAGCTCGTCCATGC & mCherry & $\mathrm{R}$ \\
\hline RBF 630 & $(1)$ & CTTGTTTCAAGGACTTAGCCATG & 5 'integration & $\mathrm{F}$ \\
\hline RBF 637 & $(2)$ & TATTCGTTGTCAGATGGCGCAC & 5 'integration & $\mathrm{R}$ \\
\hline RBF 644 & (3) & CATGTGCAGCTCCTCCCTTTC & 3'integration & $\mathrm{F}$ \\
\hline RBF 645 & $(4)$ & CCTTGTTACGACTITTGCTTC & 3 'integration & $\mathrm{R}$ \\
\hline RBF 646 & $(5)$ & ATGAAAAAGCCTGAACTCACC & HYG & $\mathrm{F}$ \\
\hline RBF 647 & (6) & CTATTCCTTTGCCCTCGGAC & HYG & $\mathrm{R}$ \\
\hline RBF 630 & (9) & CTTGTITCAAGGACTTAGCCATG & Southern probe & $\mathrm{F}$ \\
\hline RBF 631 & $(10)$ & GCGGAAACCGCAAGATITITGC & Southern probe & $\mathrm{R}$ \\
\hline
\end{tabular}

a Underlined sequence indicates restriction site.

${ }^{\mathrm{b}}$ Bold sequence indicates optimized translation initiation sequence.

'Orientation of primers: $F$, forward; $R$, reverse.

doi:10.1371/journal.pntd.0001927.t001 


\section{In vivo fluorescence imaging and calibration}

Fluorescence emission was measured using an intensified charged coupled device camera of the In Vivo Imaging System (IVIS 100, Xenogen). Wild type- and mCherry+L. major-infected animals were lightly anesthetized with $2.5-3.5 \%$ isoflurane and then reduced to $1.5-2.0 \%$. Anesthetized animals were placed in the camera chamber, and the fluorescence signal was acquired for 3 s. Fluorescence determinations, recorded by the IVIS 100 system, were expressed as a pseudocolour on a gray background, with red colour denoting the highest intensity and blue the lowest. To quantify fluorescence, a region of interest was outlined and analyzed by using the Living Image Software Package (version 2.11, Xenogen).

\section{Quantification of parasite load}

The total number of living parasites invading the target organs (popliteal lymph node draining the injected site) was calculated from single-cell suspensions that were obtained by homogenization of the tissue through a wire mesh. The cells were washed and cultured in Schneider's medium containing 20\% (v/v) heatinactivated FCS, $100 \mathrm{U} / \mathrm{ml}$ penicillin and $100 \mu \mathrm{g} / \mathrm{ml}$ streptomycin. The cell suspensions were serially diluted and dispensed into 96-well plates. The plates were incubated for 10 days and then each well was examined and classified as positive or negative according to whether or not viable promastigotes were present. The number of parasites was calculated as follows: Limit Dilution Assay Units $(\mathrm{LDAU})=$ (geometric mean of titer from quadruplicate cultures $) \times($ reciprocal fraction of the homogenized organ added to the first well). The titer was the reciprocal of the last dilution in which parasites were observed [44].

\section{Results}

\section{Generation of a functionally fluorescent $L$. major strain}

Aimed to create a $L$. major fluorescent strain we electroporated wild-type promastigotes with the lineal $5874 \mathrm{bp}$ SwaI-SwaI fragment containing the ORF encoding mCherry as well as the hyg selection marker of the pLEXSY-mCherry plasmid. After selection on semisolid plates containing $100 \mu \mathrm{g} / \mathrm{ml}$ hygromycin $\mathrm{B}$, individual colonies were seeded in M199 liquid medium supplemented with 10\% FCS and hygromycin B. Genomic DNA isolated from these cultures was used to confirm the correct integration of the target sequence into the 18S rRNA locus of $L$. major genome. Figure 1A shows a schematic representation of the planned integration. Genomic DNA from wild-type strain and two hygromycin B resistant clones were digested with $\mathcal{N} d e \mathrm{I}$ and hybridized with a labelled external probe (EP). As shown in the Southern analysis of Fig. 1B, wild-type DNA digested with $\mathcal{N} d e \mathrm{I}$ yielded an 8.4-kb hybridization band, whereas in the twohygromycin B resistant clones an additional 3.8-kb hybridization band was observed; this band is generated by the integration event (Fig. 1A) corresponding to the expected size. Further confirmation of the correct planned replacements was confirmed by PCR (Fig. 1C) using the set of primers depicted in Fig. 1A.

The mCherry expression in stable-transfected L. major promastigotes (mCherry+L. major) was monitored by flow cytometry. Cell populations of mCherry $+L$. major strain and a parasite line containing the pLEXSY-mCherry episome emitted strong red fluorescence when they were excited at wavelength of $587 \mathrm{~nm}$ (Fig. 2A). Clones with integrated $m$ Cherry gene had an average 10fold higher fluorescence than the ones expressing the gene episomally. This is an expected result given that the mCherry gene was integrated under the control of rRNA promoter, which is known to present high-level transcription rates. As shown in
Fig. 2B, both strains (episomal and integrative) were strongly more fluorescent than untransfected parasites.

In order to establish the correlation between parasite number and fluorescence intensity, different number of procyclic and metacyclic promastigotes as well as freshly isolated amastigotes from infected animals were placed in 96-well plates and their fluorescence intensity was measured spectrofluorometrically. A clear correlation between fluorescence intensity and the number of the three parasitic forms was observed (Fig. 2C).

The stability of mCherry expression was monitored over a period of 6 months after transfection and no change was observed in fluorescence intensity during this period, even in the absence of hygromycin B.

\section{In vitro infections with $\mathrm{mCherry}+L$. major parasites}

Once the infectivity of the mCherry $+L$. major parasites was recovered through mouse infections, the amastigotes obtained from cutaneous lesions were differentiated back into promastigotes. These cells were grown up to stationary phase and used to infect freshly isolated BALB/c peritoneal macrophages at a 5:1 multiplicity in 24-well plates. Figure 3 shows fluorescence images of either promastigotes or amastigotes internalized in macrophages. A strong red fluorescence emission from free-living mCherry + L. major promastigotes was observed by confocal microscopy (Fig. 3B). Similarly, round-shaped red fluorescent emitting amastigotes were observed inside parasitophorous vacuoles in the cytoplasm of the infected macrophages (Fig. 3F). The course of the in vitro infection was followed over a period of $48 \mathrm{~h}$ by measuring the absolute fluorescence of the infection and the percentage of infected macrophages. These experiments were carried out in parallel with others using the classical Giemsa staining to determine parasite load in vitro (data not shown). No differences between both methods were accounted thus pointing to the suitability of fluorescence analyses to assess the infectivity of mCherry + L. major strain on mouse macrophages. A major application of a fluorescent Leishmania model would be its usefulness to perform HTS of potential leishmanicidal compounds in vitro. To assess the suitability of our mCherry+L. major for this goal, current drugs used in the treatment of human leishmaniasis (miltefosine, paromomycin and amphotericin B) were assayed in Leishmania-macrophage infections at different concentrations over a 72 h-span. Absolute fluorescence emitted by mCherry+L. major infected macrophages was plotted vs. drug concentrations, obtaining the dose-response curves of Fig. 4. Nonlinear regression analysis of the curves, fitted by the SigmaPlot statistic package, reached $\mathrm{IC}_{50}$ values of $0.12 \pm 0.03 \mu \mathrm{M}$ for amphotericin $\mathrm{B}$, $0.57 \pm 0.12 \mu \mathrm{M}$ for miltefosine and $9.20 \pm 3.59 \mu \mathrm{M}$ for paromomycin. In all the cases the difference in fluorescence emission corresponded to a difference in the percentage of infected cells, also observed microscopically. These findings clearly showed that the mCherry + L. major strain is a useful tool for in vitro drug screening.

\section{Validation of a $\mathrm{CL}$ murine model with mCherry $+L$. major}

In order to determine whether mCherry+L. major parasites could be detected in vivo using whole-body imaging, $10^{4}, 10^{5}$ and $10^{6}$ metacyclic forms of the fluorescent-transgenic strain were injected subcutaneously into the hind footpads of six BALB/c mice per group. Lesion progression monitored both by direct measuring of fluorescence emission by mCherry+L. major amastigotes (recorded in an IVIS 100) and by the development of hind-limb lesions assessed by measuring the thickness of the footpads with a Vernier calliper. Animals were examined every seven days for a total of eight weeks (except the group infected with $10^{6}$ parasites 


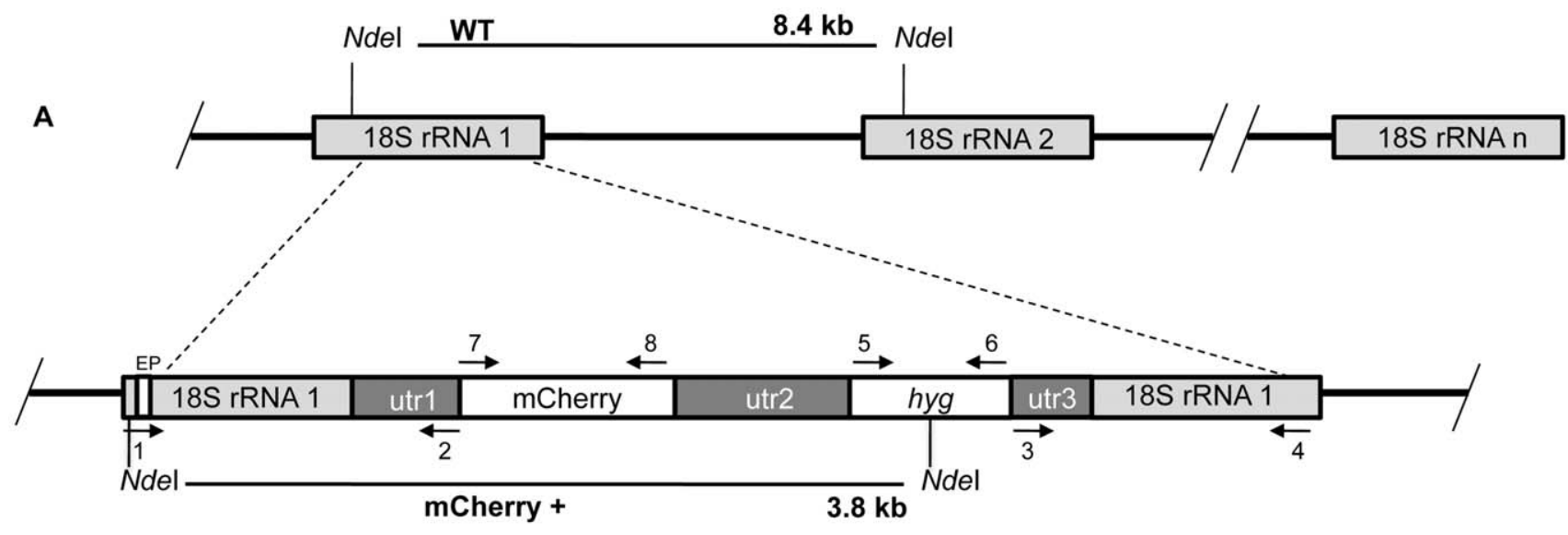

B

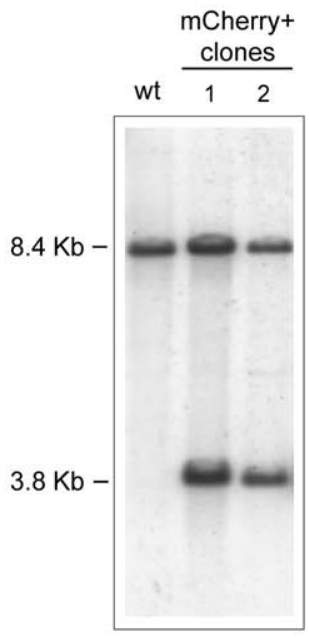

C

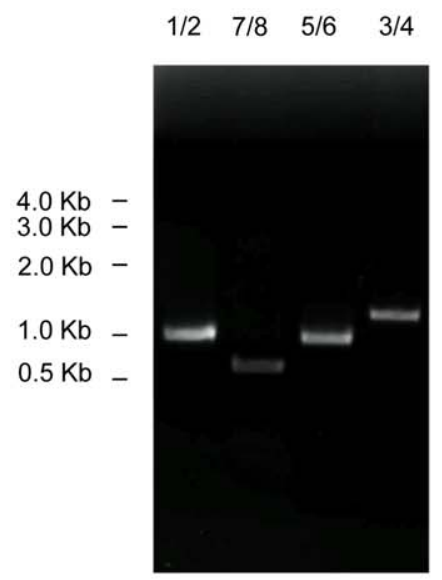

Figure 1. Strategy of integration of mCherry encoding gene into genomic rRNA locus of $L$. major. A) Scheme of the structure of the $18 \mathrm{~S}$ rRNA locus on wild type and planned integration of $m$ Cherry gene. Key: utr1: 5 'non-translated region of aprt gene; utr2: $1.4 \mathrm{~kb}$ intergenic region from cam operon; and utr3: 5'UTR of dhfr-ts gene; hyg; hygromycin B resistance cassette. The narrow white box on the left side corresponds to the external probe (EP) used for southern blot analyses. B) Southern blot analysis of two L. major clones after selection with hygromycin B. DNA was digested with Ndel and hybridized with the labelled EP. The similar intensities of 8.4 and $3.8 \mathrm{kbp}$ bands could be due to inefficiency transfer of the large band to the membrane. C) PCR confirmation of successful integration of the reporter cassette. Primers $1 / 2$ and $3 / 4$ together confirm the correct integration of the reporter cassette from the $5^{\prime}$ and $3^{\prime}$ sides, respectively. Primers $5 / 6$ confirm the presence of the HYG marker, and primers $7 / 8$, 9/10, confirm the presence of $m$ Cherry ORF, respectively. Primers: 1(RBF630); 2(RBF637); 3(RBF644); 4(RBF645); 5(RBF646); 6(RBF647); 7(RBF634) and 8(RBF600) (see Table 1 for sequences).

doi:10.1371/journal.pntd.0001927.g001

that were sacrificed at $6^{\text {th }}$ week post-infection because the appearance of ulcerations in the footpads).

Figure 5 shows the fluorescence intensity recorded weekly from the footpads of representative mice of each inoculum group $\left(10^{4}\right.$, $10^{5}$ and $10^{6}$ metacyclic promastigotes per mouse). The fluorescent signal (estimated as average radiance: $\mathrm{p} / \mathrm{s} / \mathrm{cm}^{2} / \mathrm{sr}$ ) was plotted against the infection time of each inoculum (Fig. 6A). Fluorescent signal was detected after the first week post-infection in mice infected with $10^{6}$ metacyclic parasites (radiance $=0.26 \times 10^{8} \mathrm{p} / \mathrm{s}$ / $\mathrm{cm}^{2} / \mathrm{sr}$ ), reaching a radiance of $5.0 \times 10^{8} \mathrm{p} / \mathrm{s} / \mathrm{cm}^{2} / \mathrm{sr}$ five weeks later. In the group of mice injected with $10^{5}$ metacyclic parasites, the fluorescence was detected the third week after inoculation (radiance $=0.8 \times 10^{8} \mathrm{p} / \mathrm{s} / \mathrm{cm}^{2} / \mathrm{sr}$ ), reaching similar intensity than the mice group injected with $10^{6}$ parasites at the $8^{\text {th }}$ week of inoculation. Finally, the fluorescence signal of mice injected with $10^{4}$ metacyclic mCherry + L. major parasites was not detectable until the $5^{\text {th }}$ week $\left(\right.$ radiance $=0.35 \times 10^{8} \mathrm{p} / \mathrm{s} / \mathrm{cm}^{2} / \mathrm{sr}$ ), reaching the maximum intensity $\left(\right.$ radiance $=1.14 \times 10^{8} \mathrm{p} / \mathrm{s} / \mathrm{cm}^{2} / \mathrm{sr}$ ) at the end of the experiment.

The success of infection defined as the lesion onset and its development in the inoculated footpads over the time, was observed in every mice. Although there was a good correlation to lesion size, fluorescence was more sensitive to evaluate the progression of infection. Figure $6 \mathrm{~B}$ shows that lesion emergence was dependent on the size of pathogen inoculum and it was hardly measurable during the first weeks after infection. Lesion size in $\mathrm{mm}$ was $0.34,0.94$ and 0.57 measured at the third, fifth and seventh week, respectively corresponding to $10^{6}, 10^{5}$ and $10^{4}$ metacyclic promastigotes per inoculum. It is remarkable that a weak but measurable fluorescence signal from infected hind limbs was detectable two weeks prior to visible and measurable injury took place in all dose groups.

As expected and since $\mathrm{BALB} / \mathrm{c}$ mice have a predisposition to develop an anti-inflammatory Th2 response, the lesions appearing 

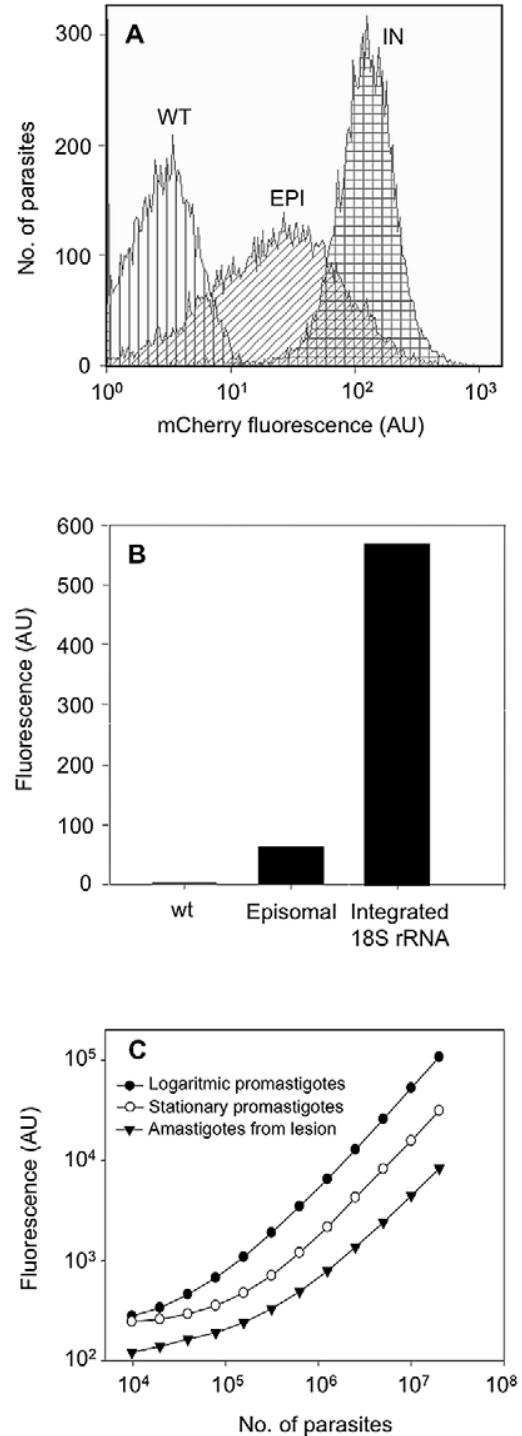

Figure 2. mCherry gene is functionally expressed in L. major parasites. Wild type (WT), pLEXSY episomal- (EPI) and integrated- (IN) $m$ Cherry expressing promastigotes were grown in the presence of hygromycin B and fluorescence levels were measured by flow cytometry. A) Histogram plot representative of the distribution of mCherry fluorescence levels in different populations of cells. B) Mean fluorescence intensity emitted by WT and the engineered parasite strains. The fluorescence is expressed as arbitrary units (AU). C) Correlation between fluorescence signal and the number of logarithmic promastigotes $(0)$, metacyclic promastigotes $(\bigcirc)$ and freshly isolated amastigotes $(\mathbf{\Lambda})$ of $m C h e r r y+L$. major. Two-fold serial dilutions were applied and parasites were counted using a Coulter counter. doi:10.1371/journal.pntd.0001927.g002

after infection setup were non-healing without treatment. A correlation analysis of the fluorescence emitted by the lesions toward the end of the 8-week period from mice infected with $10^{4}$ and $10^{5}$ metacyclic mCherry+L. major parasites (Fig. 6C) shows significant differences between both groups $(\mathrm{P}<0.001)$ using unpaired t-Student test. These differences were also found when the lesion thickness of the footpads was compared using the traditional calliper-based method (Fig. 6D). There was a clear correlation between both parameters in both dosing groups with an estimated Pearson coefficient of 0.94. At the end of the experiments, animals were sacrificed and the popliteal lymph nodes draining the lesions were dissected under sterile conditions. The parasite load of these organs was determined by the limit dilution method. Figure $6 \mathrm{E}$ shows the number of promastigotetransforming amastigotes estimated in the animals of both dosing groups, showing significant differences $(\mathrm{P}<0.001)$ and correlating highly with both size lesion and fluorescence (Pearson coefficient $=0.79$ ).

\section{Application of mCherry+L. major to a model of murine vaccination}

The suitability of this in vivo approach was assessed for the evaluation of an experimental vaccination protocol against CL that had been previously shown to be effective on a $L$. major$\mathrm{BALB} / \mathrm{c}$ infection model [35]. In previous studies, it was established that intravenous inoculation with Leishmania promastigotes, lacking both alleles of the $h s p 70-$ II gene ( $\Delta$ hsp70-II line), confers a partial protection against $L$. major infection in mice. For this study, we inoculated a group of six mice with $2 \times 10^{7}$ promastigotes of $\Delta \mathrm{hsp} 70$-II mutant and four weeks later, mice were challenged with $2 \times 10^{5}$ metacyclic forms of the mCherry $+L$. major strain into mouse footpads. In parallel to the vaccinated group, a control group was injected with the same inoculum of mCherry-expressing transgenic parasites.

Red fluorescence emission in the footpad of mice infected with mCherry + L. major parasites was followed over the time in both groups (Fig. 7A). Fluorescence signal was detected in both groups four weeks after challenge; however, fluorescence signal was higher in control group mice than in vaccinated animals. By the end of the $8^{\text {th }}$ week animals were euthanized, the poplyteal lymph nodes dissected, homogenized and the parasite load determined as above. Figure $7 \mathrm{~B}$ shows an $80 \%$ reduction $(\mathrm{P}<0.001)$ in the parasite load of popliteal lymph nodes of vaccinated group related to the control group. Therefore, since reproducible results were obtained with both parasite quantification and fluorescence emission methods, we conclude that the murine model of CL established with the mCherry+L. major fluorescent strain might be a suitable system for testing antileishmanial therapies both in vitro and in vivo.

\section{Discussion}

Transgenic parasites expressing reporter proteins are valuable tools to perform robust HTS platforms [45] and to understand the underlying mechanisms of pathogenesis [3]. GFP is one of the most commonly used reporters among fluorescent proteins. Several mutants derived from native GFP have been developed to cover longer wavelengths of the spectrum. Reporter molecules, whose emission peak is in the red spectral range, the same as mCherry, are excellent candidates for these kinds of studies. Furthermore, light absorption by tissues in the red and far-red spectra is reduced and consequently, the penetration is higher [46]. Moreover, mCherry is the best general-purpose red monomer due to its superior photostability compared to mStrawberry and DsRed, which is inadequately folded at $37^{\circ} \mathrm{C}$ [13].

The integration of the reporter gene into the 18S rRNA locus of L. major represents an efficient and effective strategy to guarantee a stable expression when the parasites need to be grown in the absence of selection drugs for both in vitro screenings and in mice infections [7,22-25,47,48].

mCherry fluorescence was detected in the different stages of the L. major life cycle. Lesion-derived amastigotes showed two times less activity than metacyclic promastigotes. In turn, these were three times less fluorescent than logarithmic promastigotes. Similar 


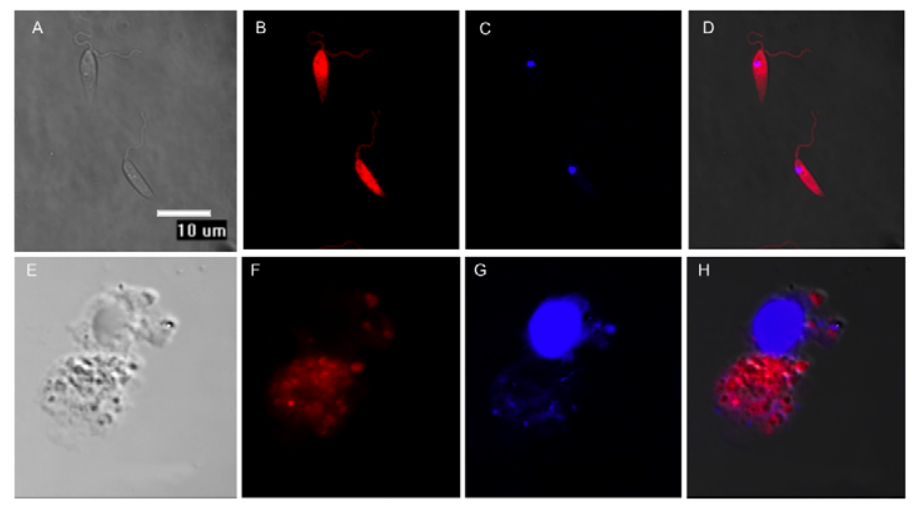

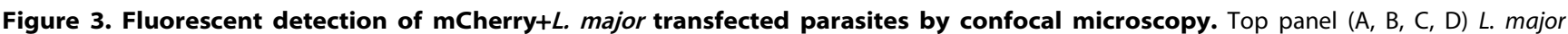
promastigotes. Bottom panel $(E, F, G, H) B A L B / c$ mouse peritoneal macrophages experimentally infected with mCherry $+L$. major metacyclic promastigotes. (A, E) Differential Interference Contrast (DIC); (B, F) mCherry+L. major emitting red fluorescence; (C, G) DAPI staining of nucleic acids; $(D, H)$ merged images. The microscopy images were acquired with a Nikon Eclipse TE2000E confocal microscope.

doi:10.1371/journal.pntd.0001927.g003

results were reported in promastigotes of different Leishmania species, in which luciferase expression was much higher than that of amastigotes from animal lesions and experimentally infected macrophages, respectively [7,47]. However, Mißlitz and coworkers [23] showed that EGFP expression levels were 2-10 times higher in amastigotes than in promastigotes of both $L$. mexicana and L. major. Although these species were stably transfected by the integration into the $18 \mathrm{~S}$ rRNA locus; they differed in the downstream region of the reporter gene. Whilst no specific $3^{\prime}$ untranslated region implicated in the stage-specific regulation was included downstream on the luc gene [47]; the intergenic calmodulin A region was configured into the pLEXSY plasmid ([7] and the present work). In a similar way, the cysteine proteinase intergenic region (cpb2.8) was included in the studies conducted by Mißlitz [23]. Intergenic sequences responsible for a high transcription rate in amastigotes should be included in future vectors for regulating the reporter's expression. In this sense, technologies such as RNA sequencing can provide a complete transcriptome that could be used to improve the expression technology in both promastigote and amastigote forms [49,50].

Assays designed to simplify rapid and large-scale drug screenings are not performed on the clinically relevant parasite stage, but on promastigotes instead. Axenic amastigotes have also been screened by means of HTS platforms [9,51,52]. However, expression arrays comparing both axenic amastigotes and those isolated from infected macrophages have shown metabolic differences, impaired intracellular transport and altered response to oxidative stress [53].

The suitability of mCherry $+L$. major transgenic strain is an important tool for bulk testing of drugs in the intracellular amastigote stage. This was demonstrated further by using three drugs in clinical use against leishmaniasis: amphotericin B, paromomycin and miltefosine.

Most of the drug screening assays attempted to analyze intracellular parasites using GFP-tranfected Leishmania spp. Theses methodologies clearly showed that there was not enough sensitivity to enable a precise and reliable microplate screening. Consequently an in-depth flow cytometric analysis is required [54]. Recently, a novel method for assessing the activity of potential leishmanicidal compounds on intracellular amastigotes through the use of resazurin (a fluorescent dye with emission wavelength in the red spectrum) has advanced to microplate analysis [55]. Unlike the GFP-expressing parasites, mCherry emission is also found in the same spectral range as resazurin. This level of sensitivity was sufficient to detect $10^{4}$ amastigotes isolated from lesions. This means that mCherry reporter provides several benefits over fluorescent proteins for performing HTS into microplate format.

Other advantages of fluorescent proteins are that they allow a dynamic follow up (kinetic monitoring) of the drug efficiency using a single plate. Drugs must be maintained in the culture medium

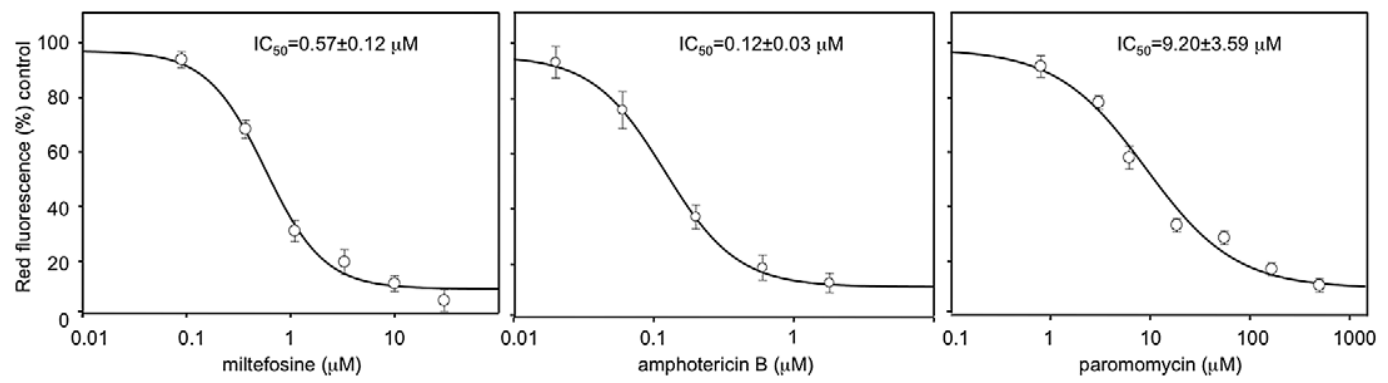

Figure 4. $\mathrm{IC}_{50}$ calculation after a 72-h period of exposure to currently used leishmanicidal drugs in infected peritoneal mouse

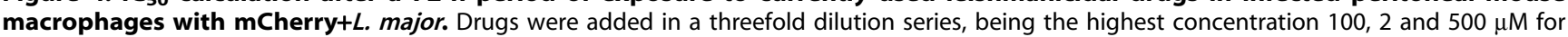
miltefosine, amphotericine $B$ and paromomycin, respectively. $I C_{50}$ values were calculated from dose-response curves performed in triplicate and repeated twice after nonlinear fitting with the SigmaPlot program.

doi:10.1371/journal.pntd.0001927.g004 

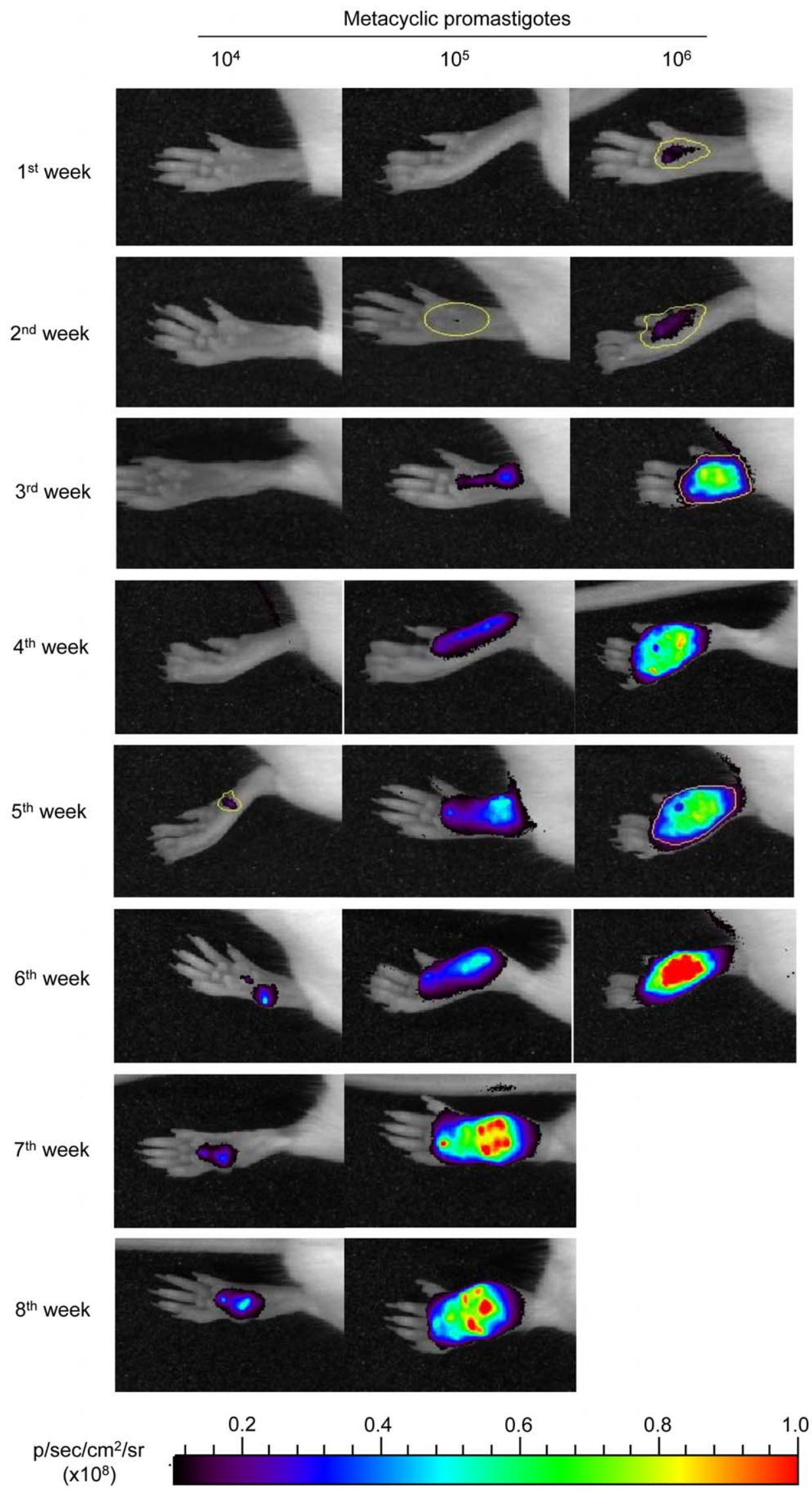
Figure 5. Progression of an experimental infection with $\mathbf{m C h e r r y}+L$. major in BALB/c mice. Photographs of mouse footpads over the time after inoculation with $10^{4} ; 10^{5}$ and $10^{6}$ mCherry+L. major metacyclic promastigotes. The images were taken weekly using an In Vivo Imaging System (IVIS 100; Xenogen) device. Six mice per dose were used in this experiment, and one representative mouse was chosen for all of the photographs. Examples of Regions of Interests (ROIs) used for quantification are marked in yellow.

doi:10.1371/journal.pntd.0001927.g005

for a time long enough for them to take effect. On the contrary, multiple plates are required if a specific substrate is added, requiring one for each recorded time interval.

Through our research we want to raise the importance of the source of host cells used for experimental infections when drugscreening assays are carried out. Several differences in the hostparasite interactions have been pinpointed when comparing primary macrophages with immortalized human macrophage-like cell lines [56]. Most of the current multiwell-screening methods involve established-macrophage cell lines since it is quite difficult to scale-up a procedure based on primary macrophages $[57,18,58,20,22,59]$. Accordingly, a well-planned combination of different approaches (promastigote/intracellular; cell line/primary cultures) would help us to identify lead compounds through largescale drug screening [60,61].

The manipulation of large numbers of potential drugs not only requires easy-to-use, repeatable and readily quantifiable tests, but also it needs to mimic natural conditions within the host cell. Because of the profound influence of the host's immune response on the treatment of leishmaniasis, new approaches should include the whole immunopathological environment found at the hostparasite interaction site. However, only one alternative approach has been used in order to transfer this immunological concept to HTS systems [43,61].

The main advantages of mCherry-transfected parasites are automation and miniaturization. As experiments are performed in 96-well plates, reducing costs of reagents, and time of analysis is of great importance. Besides, we can also eliminate tedious steps such as staining or cell lysis. In addition this allows a dynamic follow up as cells remain viable after each reading time interval.

As the stable integration of the gene encoding reporter proteins represents a valuable tool for assessing whole-body imaging in laboratory mice $[47,7,10,62-64]$, we decided to use the same mCherry-transfected strain for in vivo applications. Experimental infections with L. major in BALB/c mice footpads resulted in a nonhealing and destructive chronic lesion at the site of injection. The mCherry in vivo model developed in this study clearly allowed the fluorescence signal in the first week post-inoculation with $1 \times 10^{6}$
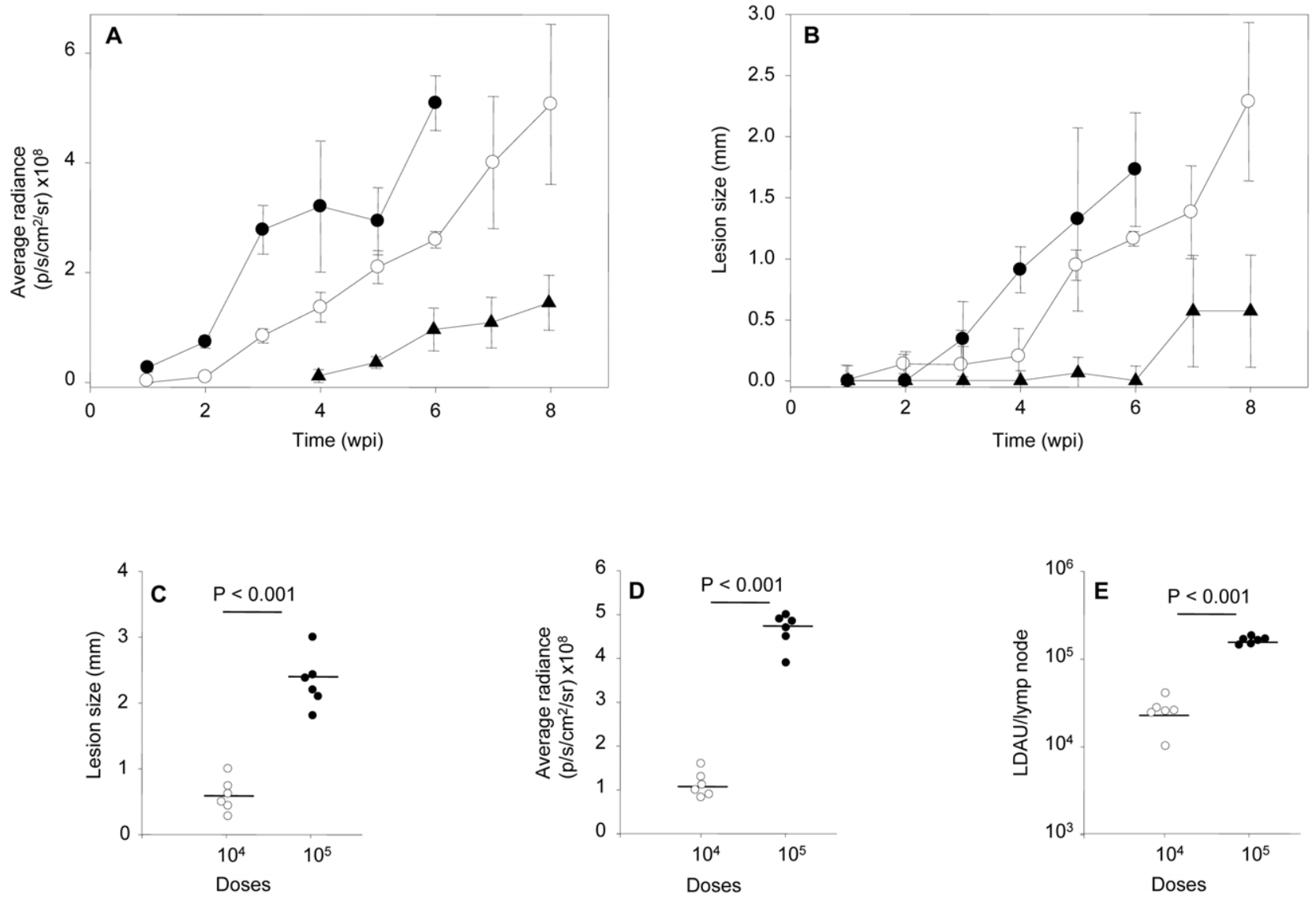

Figure 6. Follow up of the in vivo Leishmania major infection. A) Plot comparing the progression of fluorescence signal (pixel/second $\left./ \mathrm{cm}^{2} / \mathrm{sr}\right)$ mean \pm SEM over the time. (B) Plot comparing the progression of lesion size $(\mathrm{mm})$ mean \pm SEM over the time. Key: infective inocula: $10^{6}(\mathbf{C}), 10^{5}$ $(\bigcirc), 10^{4}(\mathbf{\Lambda})$ metacyclic promastigotes per mouse. Effect of infective inocula on: C) lesion size $\left.(\mathrm{mm}), \mathrm{D}\right)$ fluorescence signal (pixel/second $\left./ \mathrm{cm}^{2} / \mathrm{sr}^{2}, \mathrm{E}\right)$ parasitic load (LDAU) in the poplyteal lymph node draining the lesion of infected animals. Key: infective inocula: $10^{4}(\bigcirc), 10^{5}(\mathbf{O})$. Data were individually collected at the end of the experiment.

doi:10.1371/journal.pntd.0001927.g006 


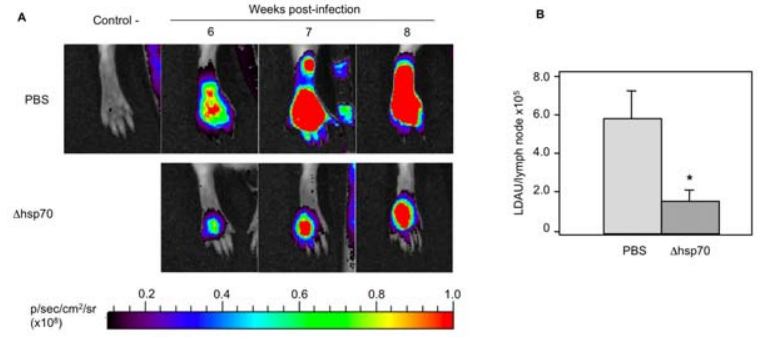

Figure 7. Effect of vaccination with $\Delta$ hsp70-II Leishmania mutant on development of a BALB/C CL model produced by mCherry+L. major strain. A) Top panel shows a non-infected animal (negative control) and the fluorescent signal emitted by hind footpads of animals infected with $2 \times 10^{5}$ metacyclic mCherry $+L$. major promastigotes at different time points. Bottom panel shows the footpads of animals immunized by intravenous administration of $10^{7} \Delta \mathrm{hsp} 70-\mathrm{II}$ metacyclic promastigotes per mouse four weeks before the challenge. Six mice in each group were imaged weekly. B) Parasite burdens in popliteal lymph nodes mean (LDAU/lymph node $\left.\times 10^{5}\right) \pm$ SEM of six animals. Statistical differences were observed between groups; *, $P<0.01$ using de paired Student $t$ test. doi:10.1371/journal.pntd.0001927.g007

stationary parasites, a dose used in leishmanial research to induce the rapid development of CL. Similar models in BALB/c mice with EGFP, used 10- and 200-fold parasite doses and the fluorescence signal was visualized afterwards [21,24]. The lymph node draining the lesion was not detected in this study, probably because the lower inoculum used or because of the shorter time of testing when the animals were killed. Previously, reports detected the fluorescence or luminescence signal emitted by the lymph node a long time after post-infection (2.5-10 months) [7,21,23].

In order to evaluate the eligibility of our fluorescent tool for the monitoring of in vivo treatments, we applied this approach by evaluating an experimental vaccine against leishmaniasis that had been previously shown to be effective. Our previous studies showed that a L. infantum strain lacking the hsp70-II gene $(\Delta \mathrm{hsp} 70$ -

\section{References}

1. Desjeux P (2004) Leishmaniasis: current situation and new perspectives. Comp Immunol Microbiol Infect Dis 27: 305-318.

2. Hutchens M, Luker GD (2007) Applications of bioluminescence imaging to the study of infectious diseases. Cell Microbiol 9: 2315-2322.

3. Lang T, Lecoeur H, Prina E (2009) Imaging Leishmania development in their host cells. Trends Parasitol 25: 464-473.

4. Saeij JP, Boyle JP, Grigg ME, Arrizabalaga G, Boothroyd JC (2005) Bioluminescence imaging of Toxoplasma gondii infection in living mice reveals dramatic differences between strains. Infect Immun 73: 695-702.

5. Franke-Fayard B, Waters AP, Janse CJ (2006) Real-time in vivo imaging of transgenic bioluminescent blood stages of rodent malaria parasites in mice. Nat Protoc 1: 476-485

6. Ploemen IH, Prudêncio M, Douradinha BG, Ramesar J, Fonager J, et al. (2009) Visualisation and quantitative analysis of the rodent malaria liver stage by real time imaging. PLoS One 4: e7881.

7. Lang T, Goyard S, Lebastard M, Milon G (2005) Bioluminescent Leishmania expressing luciferase for rapid and high throughput screening of drugs acting on amastigote-harbouring macrophages and for quantitative real-time monitoring of parasitism features in living mice. Cell Microbiol 7: 383-392.

8. Buckner FS, Wilson AJ (2005) Colorimetric assay for screening compounds against Leishmania amastigotes grown in macrophages. Am J Trop Med Hyg 72: 600-605.

9. Sereno D, Roy G, Lemesre JL, Papadopoulou B, Ouellette M (2001) DNA transformation of Leishmania infantum axenic amastigotes and their use in drug screening. Antimicrob Agents Chemother 45: 1168-1173.

10. Lecoeur H, Buffet P, Morizot G, Goyard S, Guigon G, et al. (2007) Optimization of topical therapy for Leishmania major localized cutaneous leishmaniasis using a reliable C57BL/6 model. PLoS Negl Trop Dis 1: e34.

11. Claes F, Vodnala SK, van Reet N, Boucher N, Lunden-Miguel H, et al. (2009) Bioluminescent imaging of Trypanosoma brucei shows preferential testis dissemination, which may hamper drug efficacy in sleeping sickness. PLoS Negl Trop Dis 3: e486.
II line) conferred resistance to a subsequent infection with $L$. major $[35,36]$. We found that the progression of the infection was efficiently and effectively observed by recording the mCherry signal through real-time imaging. Vaccination of infected mice for a period of 8 weeks with the vaccine reduced the infection when compared with the control group. Further to this, Mehta and coworkers successfully used a similar vaccination approach to assess the efficiency of a real-time imaging platform using an engineered strain of L. amazonensis expressing the egfp gene [24].

In conclusion, we have developed a valuable fluorescenceemitting L. major transfected strain. This strain allows us: i) actual imaging, which is important when studying tissue harvested from an infected animal because parasites can be individually identified; ii) to easily develop new, fast and efficient platforms for the screening of potential leishmanicide drugs testing thousands of compounds in Leishmania amastigote-infected macrophages; iii) to reproduce the infection in real-time due to the virulence of $L$. major-transfected strain, which in turn increases the sensitivity of detection especially at the earlier phases of the process. Furthermore, this avoids the unnecessary slaughter of large amounts of animals at different time-points owing to direct imaging and fluorescence testing, which can be performed without traumatic handling to the animals.

\section{Acknowledgments}

We appreciate SM Beverley (Washington University at Saint Louis MO, USA) for all the assistance in macrophage infections. We also thank to M Soto and V Franco (Centro de Biología Molecular Severo Ochoa, Madrid, Spain) for his assistance in recovery the infective parasites from animals.

\section{Author Contributions}

Conceived and designed the experiments: RMR MF LR JMR. Performed the experiments: ECA NAG RAV CFP CP MAL FJA. Analyzed the data: ECA NAG YPP RMR JMR. Contributed reagents/materials/analysis tools: LR RBF RMR MF. Wrote the paper: RMR RBF JMR.

12. Shaner NC, Steinbach PA, Tsien RY (2005) A guide to choosing fluorescent proteins. Nat Methods 2: 905-909.

13. Ha DS, Schwarz JK, Turco SJ, Beverley SM (1996) Use of the green fluorescent protein as a marker in transfected Leishmania. Mol Biochem Parasitol 77: 57-64.

14. Kamau SW, Grimm F, Hehl AB (2001) Expression of green fluorescent protein as a marker for effects of antileishmanial compounds in vitro. Antimicrob Agents Chemother 45: 3654-3656.

15. Singh N, Dube A (2004) Short report: fluorescent Leishmania: application to antileishmanial drug testing. Am J Trop Med Hyg 71: 400-402.

16. Chan MM, Bulinski JC, Chang KP, Fong D (2003) A microplate assay for Leishmania amazonensis promastigotes expressing multimeric green fluorescent protein. Parasitol Res 89: 266-271.

17. Okuno T, Goto Y, Matsumoto Y, Otsuka H, Matsumoto Y (2003) Applications of recombinant Leishmania amazonensis expressing egfp or the $\beta$-galactosidase gene for drug screening and histopathological analysis. Exp Anim 52: 109-118.

18. Dube A, Singh N, Sundar S, Singh N (2005) Refractoriness to the treatment of sodium stibogluconate in Indian kala-azar field isolates persist in in vitro and in vivo experimental models. Parasitol Res 96: 216-223.

19. Kram D, Thäle C, Kolodziej H, Kiderlen AF (2008) Intracellular parasite kill: flow cytometry and NO detection for rapid discrimination between antileishmanial activity and macrophage activation. J Immunol Methods 333: 7988.

20. Singh N, Gupta R, Jaiswal AK, Sundar S, Dube A (2009) Transgenic Leishmania donovani clinical isolates expressing green fluorescent protein constitutively for rapid and reliable ex vivo drug screening. J Antimicrob Chemother 64: 370-374.

21. Bolhassani A, Taheri T, Taslimi Y, Zamanilui S, Zahedifard F, et al. (2011) Fluorescent Leishmania species: development of stable GFP expression and its application for in vitro and in vivo studies. Exp Parasitol 127: 637-645.

22. Pulido SA, Muñoz DL, Restrepo AM, Mesa CV, Alzate JF, et al. (2012) Improvement of the green fluorescent protein reporter system in Leishmania spp. for the in vitro and in vivo screening of antileishmanial drugs. Acta Trop 122: $36-45$ 
23. Mißlitz A, Mottram JC, Overath P, Aebischer T (2000) Targeted integration into a rRNA locus results in uniform and high level expression of transgenes in Leishmania amastigotes. Mol Biochem Parasitol 107: 251-261.

24. Mehta SR, Huang R, Yang M, Zhang XQ Kolli B, et al. (2008) Real-time in vivo green fluorescent protein imaging of a murine leishmaniasis model as a new tool for Leishmania vaccine and drug discovery. Clin Vaccine Immunol 15: 1764 1770 .

25. Millington OR, Myburgh E, Mottram JC, Alexander J (2010) Imaging of the host/parasite interplay in cutaneous leishmaniasis. Exp Parasitol 126: 310-317.

26. Peters N, Egen J, Secundino N, Debrabant A, Kimblin N, et al. (2008) In vivo imaging reveals an essential role for neutrophils in leishmaniasis transmitted by sandflies. Science 321: 970-974

27. Ribeiro-Gomes F, Peters N, Debrabant A, Sacks DL (2012) Efficient capture of infected neutrophils by dendritic cells in the skin inhibits the early anti-Leishmania response. PLoS Pathog 8: e1002536.

28. Thalhofer CJ, Chen Y, Sudan B, Love-Homan L, Wilson ME (2011) Leukocytes infiltrate the skin and draining lymph nodes in response to the protozoan Leishmania infantum chagasi. Infect Immun 79: 108-117.

29. Lecoeur H, de La Llave E, Osorio Y, Fortéa J, Goyard S, et al. (2010) Sorting of Leishmania-bearing dendritic cells reveals subtle parasite-induced modulation of host-cell gene expression. Microbes Infect 12: 46-54.

30. De Trez C, Magez S, Akira S, Ryffel B, Carlier Y, et al. (2009) iNOS-Producing inflammatory dendritic cells constitute the major infected cell type during the chronic Leishmania major infection phase of C57BL/6 resistant mice. PLoS Pathog 5: e1000494.

31. Sadlova J, Yeo M, Seblova V, Lewis MD, Mauricio I, et al. (2011) Visualisation of Leishmania donovani fluorescent hybrids during early stage development in the sandfly vector. PLoS One 6: e19851.

32. Kimblin N, Peters N, Debrabant A, Secundino N, Egen J, et al. (2008) Quantification of the infectious dose of Leishmania major transmitted to the skin by single sandflies. Proc Nat Acad Sci USA 105: 10125-10130.

33. Graewe S, Retzlaff S, Struck N, Janse CJ, Heussler VT (2009) Going live: a comparative analysis of the suitability of the RFP derivatives RedStar, mCherry and tdTomato for intravital and in vitro live imaging of Plasmodium parasites. Biotechnol J 4: 895-902.

34. Seefeldt B, Kasper R, Seidel T, Tinnefeld P, Dietz KJ et al. (2008) Fluorescent proteins for single-molecule fluorescence applications. J Biophotonics 1: 74-82.

35. Carrion J, Folgueira C, Soto M, Fresno M, Requena JM (2011) Leishmania infantum HSP70-II null mutant as candidate vaccine against leishmaniasis: a preliminary evaluation. Parasit Vectors 4: 150.

36. Folgueira C, Quijada L, Soto M, Abanades DR, Alonso C, et al. (2005) The translational efficiencies of the two Leishmania infantum HSP70 mRNAs, differing in their $3^{\prime}$-untranslated regions, are affected by shifts in the temperature of growth through different mechanisms. J Biol Chem 280: 35172-35183.

37. Shaner NC, Campbell RE, Steinbach PA, Giepmans BN, Palmer AE, et al. (2004) Improved monomeric red, orange and yellow fluorescent proteins derived from Discosoma sp. red fluorescent protein. Nat Biotechnol 22: 1567-1572.

38. Kapler GM, Coburn CM, Beverley SM (1990) Stable transfection of the human parasite Leishmania major delineates a 30-kilobase region sufficient for extrachromosomal replication and expression. Mol Cell Biol 10: 1084-1094.

39. Späth GF, Beverley SM (2001) A lipophosphoglycan-independent method for isolation of infective Leishmania metacyclic promastigotes by density gradient centrifugation. Exp Parasitol 99: 97-103.

40. Racoosin EL, Beverley SM (1997) Leishmania major: promastigotes induce expression of a subset of chemokine genes in murine macrophages. Exp Parasitol 85: 283-295.

41. Gaur U, Showalter M, Hickerson S, Dalvi R, Turco SJ, et al. (2009) Leishmania donovani lacking the Golgi GDP-Man transporter LPG2 exhibit attenuated virulence in mammalian hosts. Exp Parasitol 122: 182-191.

42. Sacks DL, Perkins PV (1984) Identification of an infective stage of Leishmania promastigotes. Science 223: 1417-1419.

43. Osorio Y, Travi BL, Renslo AR, Peniche AG, Melby PC (2011) Identification of small molecule lead compounds for visceral leishmaniasis using a novel ex vivo splenic explant model system. PLoS Negl Trop Dis 5: e962.

44. Lima HC, Bleyenberg JA, Titus RG (1997) A simple method for quantifying Leishmania in tissues of infected animals. Parasitol Today 13: 80-82.
45. Dube A, Gupta R, Singh N (2009) Reporter genes facilitating discovery of drugs targeting protozoan parasites. Trends Parasitol 25: 432-439.

46. Lin MZ, McKeown MR, Ng HL, Aguilera TA, Shaner NC, et al. (2009) Autofluorescent proteins with excitation in the optical window for intravital imaging in mammals. Chem Biol 16: 1169-1179.

47. Roy G, Dumas G, Sereno D, Wu Y, Singh AK, et al. (2000) Episomal and stable expression of the luciferase reporter gene for quantifying Leishmania spp. infections in macrophages and in animal models. Mol Biochem Parasitol 110: 195-206.

48. Singh N, Gupta R, Jaiswal AK, Sundar S, Dube A (2009) Transgenic Leishmania donovani isolates expressing green fluorescent protein constitutively for rapid and reliable ex vivo drug screening. J Antimicrob Chemother 64: 370-374.

49. Rastrojo A, Aguado B, Carrasco F, Martín D, Crespillo A, et al. (2012) The transcriptome of Leishmania major by deep RNA sequencing: transcript annotation and relative expression levels in the axenic promastigote stage. Nucl Acids Res (submmited).

50. Holzer TR, McMaster WR, Forney JD (2006) Expression profiling by wholegenome interspecies microarray hybridization reveals differential gene expression in procyclic promastigotes, lesion-derived amastigotes, and axenic amastigotes in Leishmania mexicana. Mol Biochem Parasitol 146: 198-218.

51. Callahan HL, Portal AC, Devereaux R, Grogl M (1997) An axenic amastigote system for drug screening. Antimicrob Agents Chemother 41: 818-822.

52. Ravinder, Bhaskar, Gangwar S, Goyal N (2012) Development of luciferase expressing Leishmania donovani axenic amastigotes as primary model for in vitro screening of antileishmanial compounds. Curr Microbiol. (in press).

53. Rochette A, Raymond F, Corbeil J, Ouellette M, Papadopoulou B (2009) Whole-genome comparative RNA expression profiling of axenic and intracellular amastigote forms of Leishmania infantum. Mol Biochem Parasitol 165: 32-47.

54. Sereno D, Cordeiro Da Silva A, Mathieu-Daude F, Ouaissi A (2007) Advances and perspectives in Leishmania cell based drug-screening procedures. Parasitol Int 56: 3-7.

55. Bilbao-Ramos P, Sifontes-Rodríguez S, Dea-Ayuela MA, Bolás-Fernández F (2012) A fluorometric method for evaluation of pharmacological activity against intracellular Leishmania amastigotes. J Microbiol Methods 89: 8-11

56. Hsiao CH, Ueno N, Shao JQ Schroeder KR, Moore KC, et al. (2011) The effects of macrophage source on the mechanism of phagocytosis and intracellular survival of Leishmania. Microbes Infect 13: 1033-1044

57. Plock A, Sokolowska-Köhler W, Presber W (2001) Application of flow cytometry and microscopical methods to characterize the effect of herbal drugs on Leishmania spp. Exp Parasitol 97: 141-153.

58. Ashutosh, Gupta S, Ramesh, Sundar S, Goyal N (2005) Use of Leishmania donovani field isolates expressing the luciferase reporter gene in in vitro drug screening. Antimicrob Agents Chemother 49: 3776-3783

59. Siqueira-Neto JL, Moon S, Jang J, Yang G, Lee C, et al. (2012) An image-based high-content screening assay for compounds targeting intracellular Leishmania donovani amastigotes in human macrophages. PLoS Negl Trop Dis 6: e1671.

60. De Muylder G, Ang KK, Chen S, Arkin MR, Engel JC, et al. (2011) A screen against Leishmania intracellular amastigotes: comparison to a promastigote screen and identification of a host cell-specific hit. PLoS Negl Trop Dis 5:e1253.

61. Balaña-Fouce R, Prada CF, Requena JM, Cushman M, Pommier Y, et al. (2012) Indotecan (LMP400) and AM13-55: Two novel indenoisoquinolines show potential for treating visceral leishmaniasis. Antimicrob Agents Chemother 56: 5264-5270.

62. Thalhofer CJ, GraffJW, Love-Homan L, Hickerson SM, Craft N, et al. (2010) In vivo imaging of transgenic Leishmania parasites in a live host. J Vis Exp 41: pii 1980.

63. Lecoeur H, Buffet PA, Milon G, Lang T (2010) Early curative applications of the aminoglycoside WR279396 on an experimental Leishmania major-loaded cutaneous site do not impair the acquisition of immunity. Antimicrob Agents Chemother 54: 984-990.

64. Latorre-Esteves E, Akilov OE, Rai P, Beverley SM, Hasan T (2010) Monitoring the efficacy of antimicrobial photodynamic therapy in a murine model of cutaneous leishmaniasis using L. major expressing GFP. J Biophotonics 3: 328335 . 

"First evidence of intraclonal genetic exchange in trypanosomatids using two Leishmania infantum fluorescent transgenic clones". Calvo-Álvarez E., Alvarez-Velilla R., Jiménez M., Molina R., Pérez-Pertejo Y., Balaña-Fouce R., Reguera RM. (2014) PLoS Negl Trop Dis. 


\title{
First Evidence of Intraclonal Genetic Exchange in Trypanosomatids Using Two Leishmania infantum Fluorescent Transgenic Clones
}

\author{
Estefanía Calvo-Álvarez ${ }^{19}{ }^{,}$Raquel Álvarez-Velilla ${ }^{19}{ }^{,}$Maribel Jiménez ${ }^{2}$, Ricardo Molina ${ }^{2}$, \\ Yolanda Pérez-Pertejo ${ }^{1}$, Rafael Balaña-Fouce ${ }^{1}{ }^{*}$, Rosa M. Reguera ${ }^{1}$
}

1 Departamento de Ciencias Biomédicas, Universidad de León, Campus de Vegazana, León, Spain, 2 Unidad de Entomología Médica, Servicio de Parasitología, Centro Nacional de Microbiología, Instituto de Salud Carlos III, Majadahonda, Madrid, Spain

\begin{abstract}
Background: The mode of reproduction in Leishmania spp has been argued to be essentially clonal. However, recent data (genetic analysis of populations and co-infections in sand flies) have proposed the existence of a non-obligate sexual cycle in the extracellular stage of the parasite within the sand fly vector. In this article we propose the existence of intraclonal genetic exchange in the natural vector of Leishmania infantum.

Methodology/Principal findings: We have developed transgenic $L$. infantum lines expressing drug resistance markers linked to green and red fluorescent reporters. We hypothesized whether those cells with identical genotype can recognize each other and mate. Both types of markers were successfully exchanged within the sand fly midgut of the natural vector Phlebotomus perniciosus when individuals from these species were fed with a mixture of parental clones. Using the yellow phenotype and drug resistance markers, we provide evidence for genetic exchange in $L$. infantum. The hybrid progeny appeared to be triploid based on DNA content analysis. The hybrid clone analyzed was stable throughout the complete parasite life cycle. The progress of infections by the hybrid clone in BALB/c mice caused a reduction in parasite loads in both spleen and liver, and provided weight values similar to those obtained with uninfected mice. Spleen arginase activity was also significantly reduced relative to parental strains.

Conclusions/Significance: A L. infantum hybrid lineage was obtained from intraclonal genetic exchange within the midgut of the natural vector, suggesting the ability of this parasite to recognize the same genotype and mate. The yellow hybrid progeny is stable throughout the whole parasite life cycle but with a slower virulence, which correlates well with the lower arginase activity detected both in vitro and in vivo infections.
\end{abstract}

Citation: Calvo-Álvarez E, Álvarez-Velilla R, Jiménez M, Molina R, Pérez-Pertejo Y, et al. (2014) First Evidence of Intraclonal Genetic Exchange in Trypanosomatids Using Two Leishmania infantum Fluorescent Transgenic Clones. PLoS Negl Trop Dis 8(9): e3075. doi:10.1371/journal.pntd.0003075

Editor: Paul Andrew Bates, Lancaster University, United Kingdom

Received December 4, 2013; Accepted June 25, 2014; Published September 4, 2014

Copyright: (c) 2014 Calvo-Álvarez et al. This is an open-access article distributed under the terms of the Creative Commons Attribution License, which permits unrestricted use, distribution, and reproduction in any medium, provided the original author and source are credited.

Funding: This study was partially funded by EU grant FP7-2011-261504 EDENext and the paper is catalogued by the EDENext Steering Committee as EDENext. Ministerio de Ciencia y Tecnología (AGL2010-16078/GAN), CYTED $214 R T 0482$ and Instituto de Salud Carlos III (PI12/00104) partially supported this research. The funders had no role in study design, data collection and analysis, decision to publish, or preparation of the manuscript.

Competing Interests: The authors have declared that no competing interests exist.

*Email: rbalf@unileon.es

9 These authors contributed equally to this work.

\section{Introduction}

Leishmania is a unicellular digenetic parasite causative of several devastating zoonotic diseases in poor and developing countries. It can survive in diverse environments from the sand fly vector (promastigotes) to the mammalian host (amastigotes) where temperature, $\mathrm{pH}$ and other conditions are extremely different. In humans, once the disease is acquired several clinical forms can be manifested. Visceral leishmaniasis is the most aggressive and prevalent disease caused by Leishmania donovani in both Asia and Africa, whereas diseases caused by L. infantum are endemic to countries of the Mediterranean basin and Latin America. The disease manifests as organ swelling (specifically targeting liver, spleen and bone marrow) and may be deadly if left untreated [1].
For years, the reproductive mode of Leishmania has been assumed to be predominantly clonal, based on strong linkage disequilibrium (LD) [2,3]. Genetic population studies on different human strains of Leishmania (Viannia) braziliensis revealed substantial heterozygote deficit, which is inconsistent with a strictly clonal model of reproduction.

Alternatively a clonal/sexual reproduction and possible inbreeding is proposed [4]. In the above-mentioned studies Leishmania was considered "diploid", however aneuploidy is now proposed as the norm rather than the exception both for lab strains [5] and natural isolates [6] (for reviews see [7-8]). Nonetheless, LD analysis does not require the knowledge of ploidy [9]. These studies clash with other authors proposing sexual reproduction [10-12]. In a focus of cutaneous leishmaniasis in Turkey the number of meioses per mitosis was estimated to be 


\section{Author Summary}

Leishmaniasis is one of the most important human neglected parasitic diseases worldwide. When it appears in the visceral form it has the most aggressive outcome, and is fatal if left untreated. The current mode of reproduction of these parasites is under discussion, from propagation to a sexual reproduction process. Here, we describe for the first time the intraclonal genetic exchange between two transgenic $L$. infantum fluorescent strains in their natural vector Phlebotomus perniciosus. Hybrid clones displayed parental phenotypic traits such as yellow fluorescence and double-drug resistance. The DNA content of the hybrid lineage was $3 n$, while the parental lineage was $2 \mathrm{n}$. The hybrid clone was able to undergo all the morphogenic transitions required to complete a full life cycle to infect a susceptible mammalian host, and maintained both phenotype and genotype. However, its capacity to generate the same lesions as those observed with parental clones in BALB/c mice was reduced.

similar to the frequency of mating in co-infected sand fly studies [6].

In parallel, genetic exchange was demonstrated in landmark experiments by Beverleys' group following co-infections of Phlebotomus duboscqi sand flies with two strains of L. major. However, attempts to repeat the crosses of the parental lines during in vitro co-culture or co-infection in BALB/c mice were unsuccessful [10]. A subsequent study by the same group using four L. major strains from across its geographic range within both natural (P. duboscqi) and unnatural (Lutzomyia longipalpis) sand fly vectors confirmed that genetic exchange has no inter-specific barriers [11]. Another co-infection study in sand flies using genetically modified $L$. donovani strains, allowed the visualization and recovery of the progeny after experimental crosses, but the hybrids could not be propagated for further genotyping studies [12].

In support of the experimental work, there are some examples of naturally occurring hybrid genotypes observed in field isolates that involve different species of the L. (Viannia) subgenus [13]. L. (Viannia.) braziliensis/L. (V.) peruviana hybrids have been identified by microsatellite typing [14] and L. (V.) braziliensis/L. (V.) guyanensis hybrids are not uncommon [15-17]. Natural hybrids involving other species such as L. major and L. arabica have been reported [18,19]. Leishmania hybrids have also been identified from very distant species; L. major and L. infantum [20], and L. donovani and L. aethiopica [21].

Since mating events have been proved by genetic and experimental studies, our goal is to explore whether Leishmania is able to perform recombination between the same genotype during the mating process. We have chosen a L. infantum strain isolated from an infected dog in Spain, classified as MCAN/ES/ 1996/BCN150 zymodeme MON-1. The use of two drugselectable markers linked to fluorescent reporters (red and green), is an approach that relies on the production of yellow fluorescent hybrids as an identifiable biomarker of mating between two individuals from the same strain.

\section{Methods}

\section{Mice and parasites}

All experimental animal procedures described in this manuscript were carried out in strict accordance with the Spanish (Ley 32/2007) and European Union Legislation (2010/63/UE). The used protocols were approved by the Animal Care Committee of the University of León (Spain).

Female BALB/c mice (6-8 weeks old) were sourced from Harlan Interfauna Iberica SA (Barcelona, Spain) and housed in specific-pathogen-free facilities for this study. L. infantum (strain MCAN/ES/96/BCN 150) promastigotes were obtained from J.M. Requena (Centro de Biología Molecular Severo Ochoa, Madrid, Spain). Parasites were routinely cultured at $26^{\circ} \mathrm{C}$ in $\mathrm{M} 199$ medium supplemented with $25 \mathrm{mM}$ HEPES pH 6.9, $10 \mathrm{mM}$ glutamine, $7.6 \mathrm{mM}$ hemin, $0.1 \mathrm{mM}$ adenosine, $0.01 \mathrm{mM}$ folic acid, 1× RPMI 1640 vitamin mix (Sigma), 10\% (v/v) heatinactivated foetal calf serum (FCS) and antibiotic cocktail (50 U/ $\mathrm{ml}$ penicillin, $50 \mu \mathrm{g} / \mathrm{ml}$ streptomycin).

\section{Generation of fluorescent-transgenic Leishmania infantum}

Two fluorescent $L$. infantum strains were generated in order to overexpress two different fluorescent proteins; mCherry ( $\lambda$ exc. $587 \mathrm{~nm} ; \lambda \mathrm{em} .610 \mathrm{~nm}$ ), which was kindly provided by Dr Roger Y. Tsien - Departments of Pharmacology and Chemistry \& Biochemistry, UCSD (USA) and Citrine ( $\lambda$ exc. $516 \mathrm{~nm} ; \lambda$ em. $529 \mathrm{~nm}$ ), which was kindly provided by Dr. Juan Llopis - Facultad de Medicina and Centro Regional de Investigaciones Biomédicas, University of Castilla-La Mancha (Spain). For the CITRINEHYGROMYCIN (CTN-HYG) construct, the 720-bp CTN coding region was amplified by PCR using pcDNA3 (Invitrogen) as template and the oligonucleotides RBF613 and RBF614 as primers (Table 1 contains all primers used in this work). The amplified fragment was cut with BglII-NotI and inserted into the pLEXSY-hyg2 vector (Jena Bioscience GmbH, Germany) to yield pLEXSY-CTN-HYG construct.

For the mCHERRY-BLASTICIDIN (CHR-BSD) construct, the 711-bp $C H R$ coding region was amplified by PCR using the pRSETb-mCHERRY vector as template and primers RBF634 and RBF600. The resulting fragment was digested with BglII-NotI and inserted into the pLEXSY-hyg2 vector [22]. In this case, the $H Y G$ resistance cassette was replaced by the BSD ORF, which confers resistance to the antibiotic blasticidin S [23]. A $B S D$ resistance cassette was amplified from pXG- $B S D$ using the oligonucleotides RBF676 and RBF677 as primers. The amplified 399-bp fragment was digested with SpeI-XbaI and inserted into pSKII digested with SpeI-XbaI to generate the pSKII-BSD vector. The UTR2 from pLEXSY-hyg2 vector was amplified by PCR using the oligonucleotides RBF772 and RBF773 as primers. The amplified 1339-bp fragment was cut with NotI-SpeI and integrated into pSKII- $B S D$ vector previously cut with the same restriction enzymes, to generate the pSKII- $B S D$-UTR2 vector. The 1738-bp UTR2-BSD fragment was then generated after digestion with NotI-SpeI and inserted into the pLEXSY-CHR, which was previously cut with the same enzymes, yielding pLEXSY-CHR-BSD.

Parasites expressing $C H R-B S D$ and $C T N-H Y G$ reporters linked to their corresponding antibiotic-resistance cassettes were obtained after the electroporation of $L$. infantum promastigotes with the large SwaI targeting fragment from pLEXSY-CHR-BSD and pLEXSY-CTN-HYG vectors and plated on semisolid medium [24]. Transgenic L. infantum promastigotes derived from the integration of both reporters into the leishmanial $18 \mathrm{~S}$ rRNA locus were selected on semisolid medium containing $200 \mu \mathrm{g} / \mathrm{ml}$ of hygromycin B or blasticidin S, respectively and confirmed by PCR analysis. In addition, a strong fluorescent signal from both mCherry and Citrine was detected by flow cytometry (Cyan ADP, Dako) and fluorescence microscopy (Nikon Eclipse TE2000E). Parental clones CHR+ L.infantum and CTN+ 
Table 1. Oligonucleotides used in this work.

\begin{tabular}{|c|c|c|}
\hline Oligo No. & Sequence ${ }^{a, b}$ & Purpose $^{c}$ \\
\hline RBF613 & ccgCTCGAGgaAGATCTCCACCATGGTGAGCAAGGGCGAGG & Citrine $\mathrm{F}$ \\
\hline RBF613 & ataagaatGCGGCCGCTTACTTGTACAGCTCGTCCATG & Citrine $\mathrm{R}$ \\
\hline RBF634 & ccgCTCGAGgaAGATCTCCACCATGGTGAGCAAGGGCG & mCherry $\mathrm{F}$ \\
\hline RBF600 & ataagaatGCGGCCGCTTACTTGTACAGCTCGTCCATGC & mCherry $\mathrm{R}$ \\
\hline RBF630 & CTTGTTTCAAGGACTTAGCCATG & $5^{\prime}$ integration $\mathrm{F}$ \\
\hline RBF644 & CTCGTGTGAGCGTTCGCG & 3'integration $\mathrm{F}$ \\
\hline RBF645 & СTACCTTGTTACGACTITGC & 3'integration $\mathrm{R}$ \\
\hline RBF676 & gCTCTAGACCACCATGGCCAAGCCTTTGTCTCAAGAA & BSD F \\
\hline RBF677 & ggACTAGTTTAGCCCTCCCACACATAACCAG & BSD R \\
\hline RBF772 & ataagaatGCGGCCGCCCTCCTCCTCCTTTCTTGTTCC & utr2 F \\
\hline RBF773 & gсTCTAGAGGCTGCTGTGGAGGTGTGTAG & utr2 R \\
\hline
\end{tabular}

L.infantum (hereafter referred to as $C H R+$ and $C T N+$ ) were used to infect mice in order to recover the lost infectivity after cloning and plating.

\section{Promastigote co-cultures and Balb/c co-infections as platform to generate hybrids}

In order to assess the capacity of $L$. infantum to create hybrid progeny in vitro, both parental lines were co-cultured. Promastigotes transformed from lesion amastigotes (spleen), were mixed at an equal ratio (1:1) in M199 medium. Double antibiotic selection was started once the culture reached the stationary growth phase. Hygromycin B and blasticidin S were added on days 7, 11 and 15 after mixing the parental lines. All parasites were dead by this time. The experiment was repeated three independently times including three replicates. In parallel, parental lines that had recovered their infective capacity by passing independently through mice were used to co-infect BALB/c mice. A mix (1:1) of stationary cultures $\left(2 \times 10^{7}\right)$ was intraperitoneally injected into female mice (8-weeks old) in a single experiment using 5 animals. Five weeks post-infection, mice were sacrificed and spleens and livers were dissected and processed through a wire mesh and cultured in M199 plus $10 \%$ FBS at $26^{\circ} \mathrm{C}$. Five days later, promastigotes were seen on cultures. Double drug selection was applied at days 5, 9 and 13. All parasites were dead by this time.

\section{Experimental sand fly infections}

A local colony of $P$. perniciosus sand flies (Madrid) was maintained at $26^{\circ} \mathrm{C}$, with a 17 -h light/7-h dark photoperiod and 95-100\% of relative humidity at the Medical Entomology Unit of the Instituto de Salud Carlos III, Madrid (Spain). This colony was established in 1987 from sand flies captured at a Leishmania endemic area of Madrid. Two different protocols were carried out. In the first approach, 3-day old female sand flies were infected by feeding through a chick skin membrane on heat-inactivated rabbit blood containing a mixture $(1+1)$ of logarithmic phase promastigotes of CHR+ and CTN+ at a cell density of $2 \times 10^{7}$ promastigotes $/ \mathrm{ml}$. Eight days post-feeding sand flies were dissected in sterile saline and gut contents were transferred directly to $96-$ well plates containing $0.2 \mathrm{ml}$ media without antibiotics. Eleven days post-blood meal, a new session of dissections among surviving sand flies was done. In the second protocol 5-day old female sand flies were fed with a mixture $(1+1)$ of $1 \times 10^{7}$ logarithmic phase promastigotes of $C H R+$ and $C T N+$ promastigotes $/ \mathrm{ml}$. Sand fly midguts were dissected 6 days after feeding and the number of viable parasites was determined by counting in a hemocytometer chamber. Hybrid clones were selected by growing the recovered parasite mixture in 24-well plates containing $1 \mathrm{ml}$ of M199 medium supplemented with $100 \mu \mathrm{g} / \mathrm{ml}$ of both hygromycin B and blasticidin S. Fresh M199 medium and antibiotics were replaced every 5 days. PCR was performed to confirm the integration of the $C H R-B S D$ and $C T N-H Y G$ cassettes in the 18S rRNA locus and Southern blot analysis was used to confirm genetic exchange between both parental strains within the sand fly gut. Confocal microscopy was also conducted to confirm the hybrid phenotype.

\section{In vitro infections}

THP-1, the human acute leukemia monocyte cell line (ATCG TIB-202), was cultivated in RPMI medium supplemented with $10 \%$ heat-inactivated FBS and 1\% streptomycin/penicillin at $37^{\circ} \mathrm{C}$ and $5 \% \mathrm{CO}_{2}$. The cultures were diluted every 3 or 4 days to maintain the cell density between $10^{5}$ cells $/ \mathrm{ml}$ and $8 \times 10^{5}$ cells/ ml. THP- 1 cells at $5 \times 10^{5}$ cells $/ \mathrm{ml}$ were differentiated with $50 \mathrm{ng} /$ $\mathrm{ml}$ of phorbol 12-myristate 13-acetate (PMA) for 48 hours at $37^{\circ} \mathrm{C}$ and $5 \% \mathrm{CO}_{2}$. Stationary promastigotes of each parental and hybrid strains (5-6 day cultures) freshly transformed from lesion amastigotes were added to differentiated-macrophages at 1:10 ratio for $24 \mathrm{~h}$ at $37^{\circ} \mathrm{C}$. Then, the parasites that have not been internalized were removed by washing with phosphate buffered saline (PBS). Intracellular infections were analyzed after $72 \mathrm{~h}$.

\section{In vivo infections and parasite quantification}

Strains infectivity was recovered passing through BALB/c mice. Female BALB/c mice (5 animals per group) were injected intraperitoneally with either $10^{7}$ infective-stage metacyclic promastigotes of L. infantum BCN 150 wild type, CHR+, CTN+ or Hybridl. Stationary cells freshly transformed from lesion amastigotes were used for the negative selection of metacyclic parasites with peanut agglutinin [25]. After 5 weeks of infection, these animals were euthanized and their spleens and livers were dissected and weighed. The total number of living parasites in the organs was calculated from single-cell suspensions that were obtained by homogenization of the tissue through a wire mesh. 
A

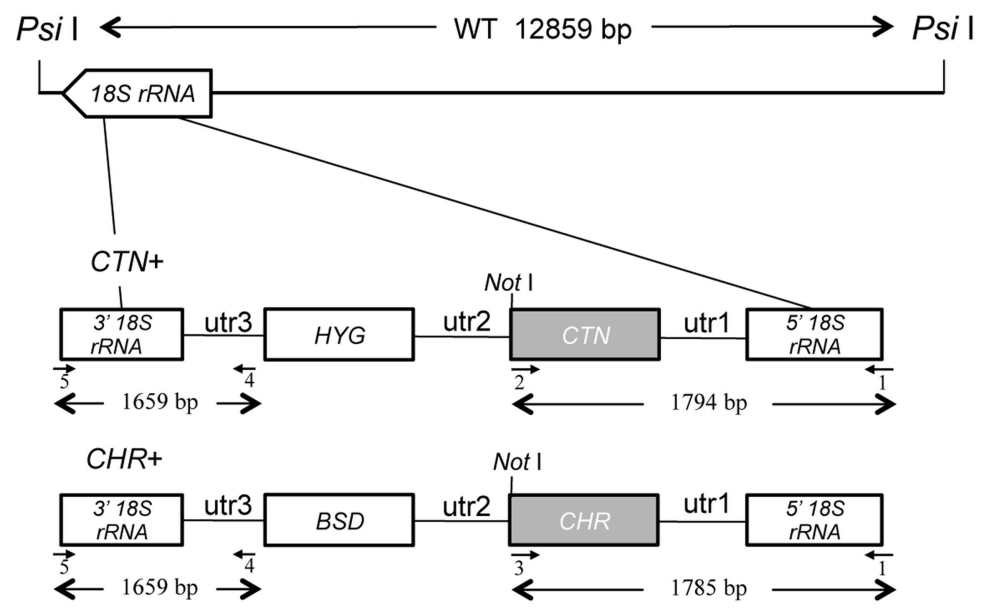

B

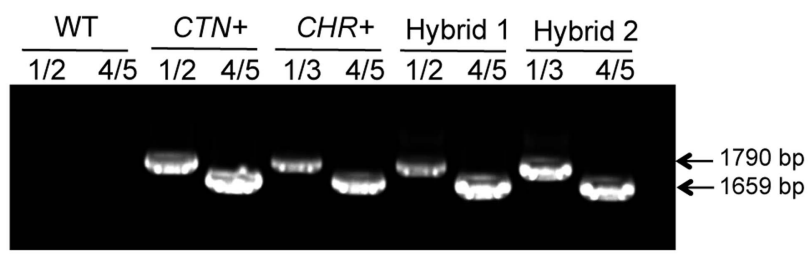

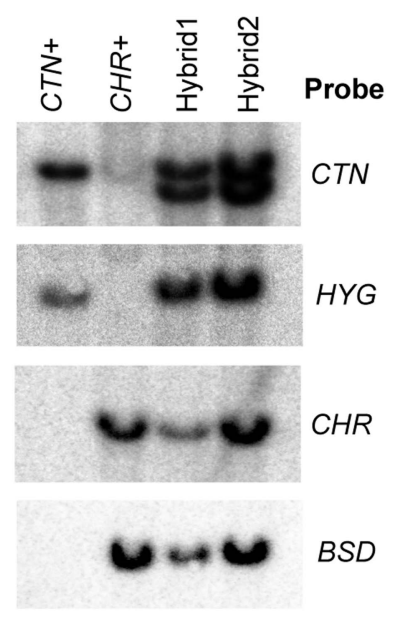

D

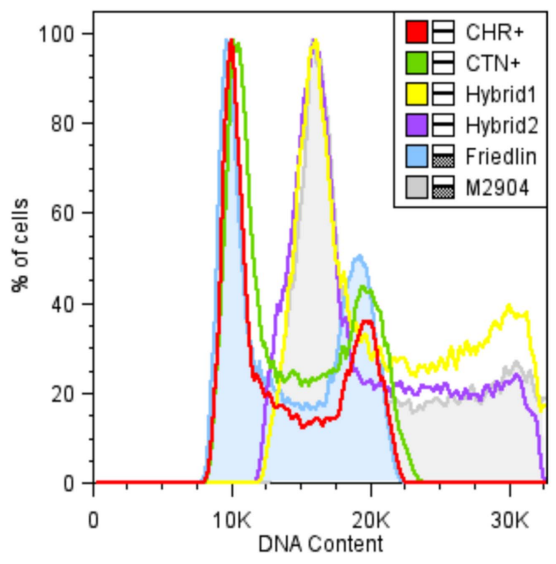

Figure 1. Generation of parental clones and molecular characterization of the hybrid progeny. A) Schematic view of one copy of the $18 \mathrm{~S}$ rRNA loci on WT and planned integration of the stably-transfected L. infantum. B) PCR amplification of the genes encoding fluorescence and antibiotic resistance reporters using the following primers: 1 (RBF630), 2 (RBF614), 3 (RBF600), 4 (RBF644), 5 (RBF645). C) Autorradiography showing Southern blot analysis using four different probes (CTN, HYG, CHR and BSD ORFs), in parental (CTN+, CHR+) and two hybrids. DNA was digested with Psil combined with Notl. The DNA amount loaded in lane 3 (Hybrid1) is lesser than in other lanes. D) DNA contents of parental and Hybrid 1 and 2 clones. L. major Friedlin FV1 and L. braziliensis M2904 were introduced as representative (diploid and triploid) strains in the analysis. doi:10.1371/journal.pntd.0003075.g001

Briefly, liver and spleen homogenates $(100 \mathrm{mg} / \mathrm{ml})$ were serially diluted in complete Schneider's medium and distributed in 96-well plates at $26^{\circ} \mathrm{C}$. After 10 days, each well was examined and categorized as positive or negative according to the presence of viable promastigotes. The number of parasites was calculated as follows: Limit Dilution Assay Units $($ LDAU) $=$ (geometric mean of titer from quadruplicate cultures $) \times($ reciprocal fraction of the homogenized organ added to the first well). The titer was the reciprocal of the last dilution in which parasites were observed [26].

\section{DNA content analysis}

Total DNA content was determined by flow cytometry following staining of $10^{6}$ permeabilized RNase-treated cells with propidium iodide. L. infantum promastigotes $\left(5 \times 10^{6}\right)$ were washed with PBS and fixed with 70\% methanol-30\% PBS for $30 \mathrm{~min}$ at $4^{\circ} \mathrm{C}$. Parasites were pelleted, washed twice with PBS, resuspended in $1 \mathrm{ml}$ of PBS containing $20 \mu \mathrm{g} / \mathrm{ml}$ propidium iodide and $200 \mu \mathrm{g} / \mathrm{ml} \mathrm{RNase} \mathrm{A}$, and incubated at $25^{\circ} \mathrm{C}$ for $1 \mathrm{~h}$. Data were acquired on a FACS flow cytometer (Becton Dickinson), counting at least 10,000 cells per sample, and analyzed using CellQuest 3.1 (BD Bioscience) software.

\section{Arginase activity and nitric oxide content}

The alternative activation of macrophages was assessed by means of determining the arginase activity using the rate of urea yielded from L-arginine in the presence of the chromophore 1phenyl-1,2-propanedione-2-oxime (ISPF) at $540 \mathrm{~nm}$ [27]. The amount of nitric oxide (NO) from infected spleens was indirectly measured using a colorimetric assay based on the Griess reaction [28].

\section{Results}

Hybrids are generated on the sand fly $P$. perniciosus

The parental clones were tested for their ability to generate doubly drug-resistant parasites during co-infections on the sand fly. In the first protocol a total of 289 sand flies were fed, and after 8 days, 66 of them were dissected and 21 midguts were positive for promastigotes $(21 / 66)$ giving a transmission index of $32 \%$. Eleven days post-blood-feeding, 54 new dissections among surviving sand flies were done resulting in 20 positive flies. However, due to fungal contamination, only 15 samples had a "clean gut" (15/54) giving a transmission index of $27 \%$. A mix of green and red 
parasites was detected after sand fly dissections. No promastigotes survived after double drug selection.

In the second protocol 373 sand flies were fed and six days later, 35 were dissected, and 23 guts were positive for promastigotes (23/35) giving a transmission index of $65 \%$. The number of promastigotes per midgut was between 2000 and 5000 . Using this protocol only one gut was lost due to fungal contamination. Microscopic analysis showed a mixture of green and red parasite and an intermediate orange color promastigotes after dissection of the sand flies (data not shown). Two populations (isolated from different flies) were resistant to both drugs giving a recombination rate per doubly infected sand fly of $8 \%$. For each doubly drug-resistant population, only a single clone was selected for further analysis.

\section{Hybrid clones displayed a hybrid genotype and a yellow phenotype}

Once double antibiotic selection was done, clonal promastigotes were recovered by plating them on semi-solid media containing both drugs. Only one clone from each hybrid was selected. Therefore, all the molecular work was conducted with two hybrid clones.

PCR analysis with specific primers for parental markers $(H Y G$, $B S D, C T N$ and CHR) (Fig. 1A) showed that all doubly drugresistant clones contained both genes encoding the antibiotic resistance proteins and both reporter genes. The proper location of the marker genes within the 18S rRNA locus was confirmed for all the clones (Fig. 1B).

Southern blot analysis was performed for four different genes $(C T N$ and $C H R$ as reporter genes, and $H Y G$ and $B S D$ as antibiotic cassettes). Figure $1 \mathrm{C}$ showed that all doubly drugresistant clones tested contained the $H Y G$ and $B S D$ drug resistance genes as well as the $C T N$ and $C H R$ reporter genes. However, two hybridization bands corresponding to $C T N$ were detected. The smaller size of one of them could be the result of chromosomal rearrangement. This might suggest that both hybrid clones have inherited two chromosome copies from the $C T N+$ and one chromosome copy from $\mathrm{CHR}+$.

In order to confirm the hypothesis of a triploid hybrid strain, total DNA content of the progeny clones was measured and compared to that of the parental strains by flow cytometry. L. major Friedlin FV 1 and L. braziliensis M2904 were introduced in the analysis as representative "diploid" and "triploid" strains respectively [5]. While parental strains showed 2n DNA contents, hybrid progeny showed 3n DNA contents, their pattern being similar to $L$. braziliensis M2904 (Fig. 1D). These results suggest that the hybrid had inherited two genomic complements from the CTN-HYG and one from $C H R-B S D$ parents.

The yellow fluorescent phenotype was detected from doubly drug-resistant hybrids (both hybrids were yellow, only Hybridl is shown) (Fig. 2A). The growth rate of both hybrids as promastigotes in M199 with selection antibiotics (hygromycin B and blasticidin S) was slower than that observed in parental lines in the presence of drugs (Fig. 2B). This effect disappeared when drugs were removed (data not shown).

Since the genotype, determined by PCR and Southern blot, was similar for both hybrids, mice infection experiments were performed only with one of the hybrids (hereafter referred to as Hybrid1). To confirm that hybrid formation was stable throughout the complete parasite life cycle, BALB/c mice were injected intraperitoneally with $10^{7}$ stationary-phase Hybridl promastigotes. Five weeks post-infection, animals were sacrificed and parasites were recovered from infected organs (liver and spleen). Freshly transformed promastigotes were again analyzed by confocal microscopy and the stability of the progeny was
A
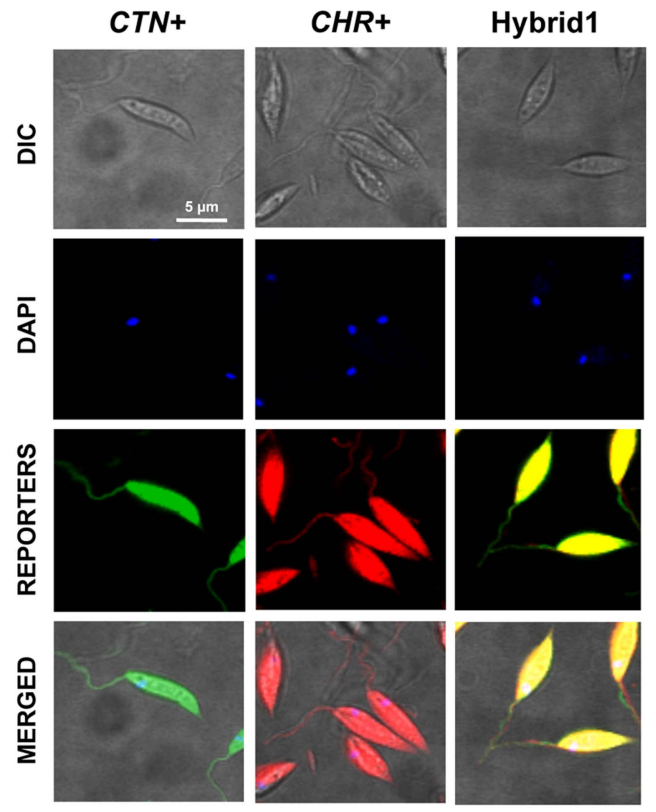

B
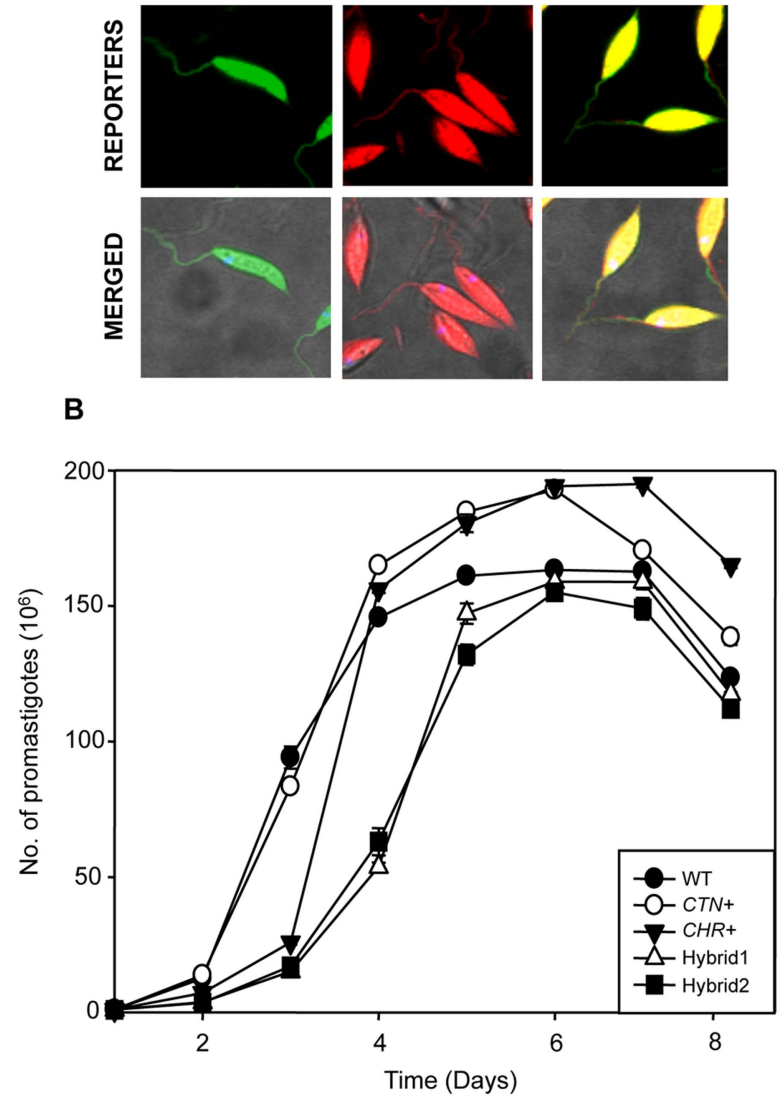

Figure 2. Confocal microscopy analysis of parental and hybrid clones and comparative growth rate analysis. A) L. infantum promastigotes were grown in $\mathrm{M} 199$ at $26^{\circ} \mathrm{C}$ in the presence of $100 \mu \mathrm{g} /$ $\mathrm{ml}$ hygromycin $\mathrm{B}$ and blasticidin S. Microscopy images were acquired with a Nikon Eclipse TE2000E confocal microscope. B) Growth rate of parental and hybrid promastigotes in the presence of the corresponding selection antibiotics. Cell density was measured by Coulter. This figure only shows Hybrid1 (Hybrid2 grows similarly, data not shown). Experiments were carried out by triplicate and error bars represent standard deviations.

doi:10.1371/journal.pntd.0003075.g002

confirmed through the analysis of total DNA contents (data not shown). Freshly recovered parasites were used to infect differentiated THP-1 macrophages, where the yellow phenotype was conserved (Fig. 3), thus confirming that the hybrid was stable throughout the whole parasite life cycle.

The hybrid differs in virulence traits in BALB/c mice and macrophage infection

The ability of parental and hybrid strains to survive and replicate in differentiated THP-1 macrophages was assessed. The 

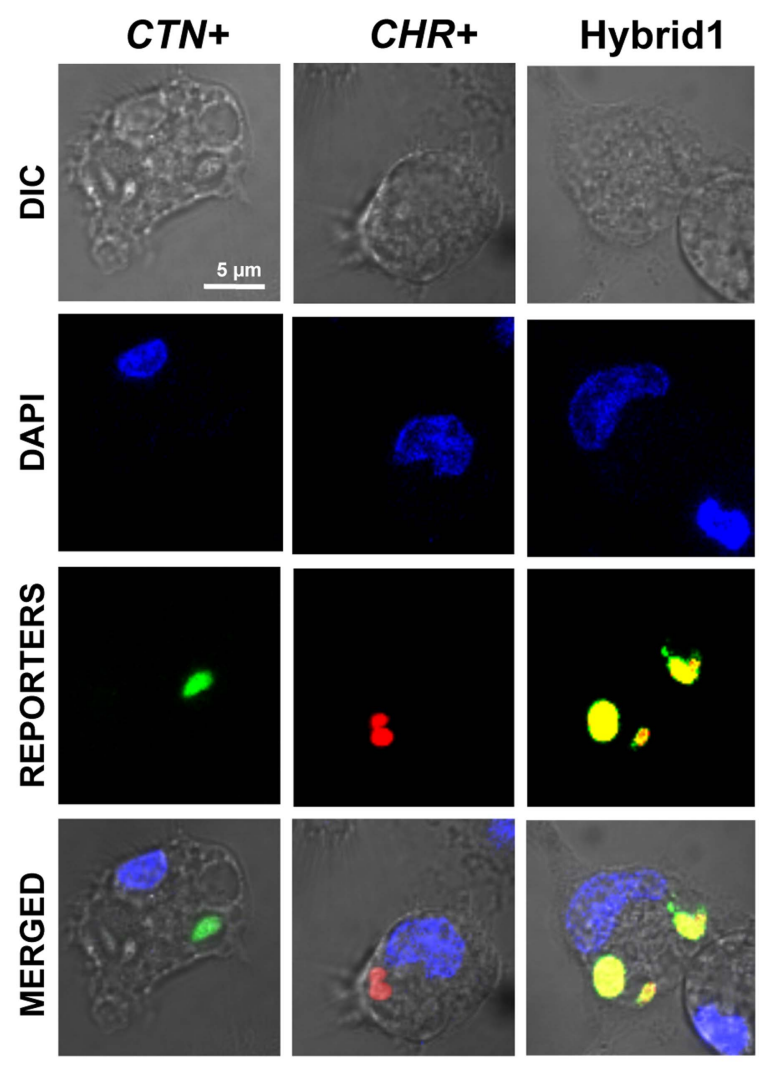

Figure 3. Hybrid parasites are stable and retain yellow fluorescence throughout the whole parasite life cycle. Metacyclic promastigotes (parental and Hybrid1 clones) transformed from amastigotes were co-cultured with differentiated human THP-1 macrophages (ratio $10: 1$ ) at $37^{\circ} \mathrm{C}$ and $5 \% \mathrm{CO}_{2}$. After $24 \mathrm{~h}$ the wells were washed and the infected macrophages were maintained under similar conditions for further $48 \mathrm{~h}$. Microscopy images were acquired with a Nikon Eclipse TE2000E confocal microscope.

doi:10.1371/journal.pntd.0003075.g003

time-course of fluorescence emitted by infected macrophages showed significant differences between parental and hybrid clones. The former exhibited higher infection and replication rates, which is represented by an increase in the fluorescent emission along the time-course. The latter showed lower infection rates and its proliferation ability was impaired (Fig. 4A). These results were also confirmed by the percentage of infected macrophages using Giemsa staining. A wild-type (WT) strain was also included only for comparative purposes (Fig. 4B). The arginase activity was significantly reduced in the Hybridl in comparison with to parental strains (Fig. 4G).

Progression of infection in BALB/c mice by parental and hybrid progeny clones was analyzed 5 weeks post-infection. Spleens from infected mice were 4-7 fold bigger than those dissected from uninfected mice (ca. $0.1 \mathrm{~g}$, data not shown), with the exception of mice infected with Hybridl clone, whose spleen weight values were around $0.2 \mathrm{~g}$ (Fig. 5A).

Total parasite load of spleens and livers was measured using the LDA method. Parasite load per gram of tissue was $10^{6}-10^{7}$ in liver and spleen, respectively in all infected mice with the exception of those mice infected with the Hybridl clone. In this case, parasite load was 3 to 4 log lower (liver and spleen, respectively) $(\mathrm{p}<0.001)$ than with the WT or parental strains (Fig. 5B). Freshly recovered parasites were grown to stationary phase and peanut agglutinin was used to agglutinate preferentially procyclic parasites. Negative selection of metacyclics showed no differences between different cell lines (parental and Hybrid1) (data not shown).

To gain further insight into the different virulence traits among the parental and Hybridl clones, we assessed arginase activity and nitric oxide (NO) production in splenocytes isolated from BALB/c mice infected with parental and Hybridl clones. Arginase activity remained similar in WT and parental strains. However, a significant decrease was observed in mice infected with Hybridl (Fig. 5C). When supernatants from these cultures were analyzed for nitrite formation by means of the Griess assay, similar values were obtained in all cases (Fig. 5D). Despite the differences in arginase activity induced by parental and Hybridl clones, there was no correlation with NO production, which suggests its insignificant role in disease progression. These results indicate that the reduced pathology found in mice infected with Hybridl was not the result of increased parasite clearance due to a competitive advantage to metabolize L-arginine via the inducible NO synthetase pathway, but to the impaired virulence of the hybrid line.

\section{Discussion}

In this study we have isolated for the first time in L. infantum doubly drug-resistant intraclonal yellow hybrids, which confirm the capacity of Leishmania to experience mating within the sand fly vector. Using a system that co-express two reporter genes, two yellow hybrid clones were isolated in a straight-forward manner, extending the genetic exchange not only to cutaneous but also to visceral strains. Additionally, yellow hybrids were generated with individuals of the same $L$. infantum strain, which suggests that Leishmania is capable of performing recombination between the same genotype. The percentage of yellow population recovered from total dissected midguts, $(2 / 59)$ was $3.4 \%$. However, $8-13 \%$ recovery was reached in co-infections with $L$. major species $[10,11]$ and up to $20 \%(25 / 121)$ in experiments with L. donovani, [12] although finally none of them were able to survive. Although the low number of hybrid progeny recovered in the present study might suggest that the occurrence of mating in visceral strains is lower than in cutaneous ones, the estimation of meiosis events of L. infantum isolates from a focus of cutaneous leishmaniasis in Turkey, gave similar values to those found in experimental trials [6]. The most plausible explanation to the low number of hybrids recovered maybe that intraclonal mating is more unlikely than inter-clonal mating. These results are in concordance with those obtained with the agent responsible for African trypanosomiasis after intraclonal crossing [29].

In the first approach carried out with flies dissected only at late time points (8-11 days), the hybrid recovery was null. Surprisingly, although a time-course was not the aim of this work, shorter coinfection experiments rendered two yellow hybrids by day 6 . Previous studies with $L$. donovani co-infecting $P$. perniciosus did not yield viable hybrids, although yellow progeny was described as soon as 3 days after co-infection [12]. Similarly, early hybrid formation (6-8 days post-infection) was pointed by Inbar et al. using L. major strains [11]. The frequency of genetic exchange in the co-infected sand fly experiments was $2-5 \times 10^{-4}$. Data were roughly comparable in all the previous studies ranging from $<10^{-4}$ to $2.5 \times 10^{-5}$.

For both hybrids, the inheritance of four parental selectable markers was confirmed by PCR. Further evidence of chromosomal recombination was the presence of two CTN copies of different sizes in the hybrid progeny. The smaller size of one of the copies might be explained by chromosomal rearrangements outside the integration locus. However, parental controls showed 

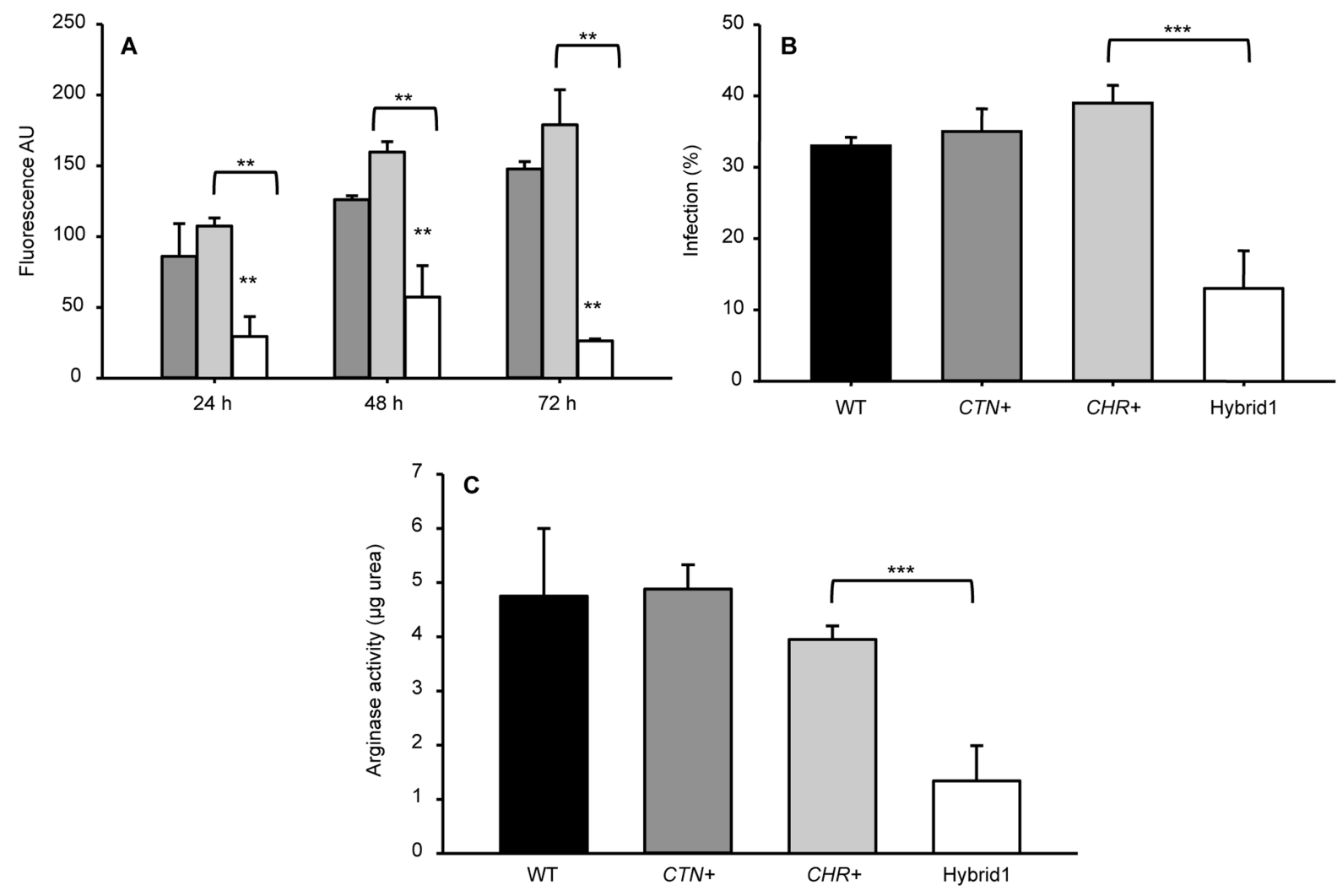

Figure 4. Low infection rate and proliferation impaired in Hybrid1 clone. Differentiated THP-1 macrophages were infected with WT [black]), parental strains (CTN+ [dark gray], CHR+ [light gray] or Hybrid1 [white] and free parasites were washed away after $24 \mathrm{~h}$. A) Time course of the fluorescence emitted by the parental clones and the hybrid progeny. B) Infection rate determined by Giemsa staining of the macrophages infected with the parental and hybrid lineages after $72 \mathrm{~h}$ post-infection. C) Total arginase activity was determined as described in the Materials and Methods section. Data are presented as the mean \pm standard deviation and are representative of two different experiments with similar results; ${ }^{* *}, p<0.05$; ***, $\mathrm{p}<0.001$.

doi:10.1371/journal.pntd.0003075.g004

that the marker loci had not undergone rearrangement during hybrid formation, thus maintaining their proper location within the $18 \mathrm{~S}$ rRNA locus. Total DNA content analysis showed that both hybrids were triploids. No diploid, tetraploid or intermediate DNA contents were detected, although the presence of a small number of aneuploid chromosomes may not have been detected by the methods employed in this study.

Hybridl was used to infect mice. Recovered promastigotes transformed from lesion amastigotes had yellow phenotype, maintained the doubly drug-resistance and the 3n DNA contents, which evidenced that they were stable throughout the whole parasite life cycle. Ploidy analysis by flow cytometry showed that most of the hybrids recovered from L. major and T. bruce $i$ were diploid like the parental lines, but a significant percentage of hybrids with increased DNA contents $(3-4 n)$ was also detected [10,11,30-32]. This effect was also observed when double gene replacement was conducted in order to knock down an essential gene [33]. Leishmania genome contains $\sim 8000$ predicted proteincoding genes and is approximately $33 \mathrm{Mb}$ in size [34]. A 1.5-2 increase in DNA content, equivalent to $16.5-33 \mathrm{Mb}$, can be only reasonably explained by the duplication of chromosomal material either endogenously or through genetic exchange. Triploids have been considered most likely to be formed by models in which one diploid parental strain omits meiotic reduction and fuses with a haploid gamete provided by the other progenitor (i.e. $2 n+n$ ) [35]. Mendelian segregation is well established since long in $T$. brucei [36] and more recently meiosis-specific proteins were expressed in the nucleus mostly before cell fusion [37]. In addition, a promastigote-like cell with haploid DNA contents has been described [38], demonstrating that this excavate protist is essentially a sexual organism. Orthologs of the meiosis-specific genes are present in the L. infantum genome and therefore, further studies to demonstrate their functionality during infections in sand fly should be conducted to definitely establish the meiotic program in Leishmania. In this scenario triploid hybrids can be generated by the previously proposed idea of fusion between haploid and diploid cells.

The viability and virulence of the $L$. infantum hybrid clone are also important results. The increased arginase activity has been associated with the disease status in patients with visceral leishmaniasis. A local depletion in L-arginine impairs the ability of CD4 T cells to proliferate in the lesion and produce IFN- $\gamma$ [39]. In this study, the decrease in arginase activity expressed by both THP-1 and splenocytes infected with the Hybridl clone suggests a "slow virulence phenotype" in disease progression, and this has not been associated with the growth rate. In Candida albicans, tetraploid strains have been described to be less virulent than isogenic diploid strains [40]. Adaptation to the mammalian host environment involves stressful conditions, which requires a 

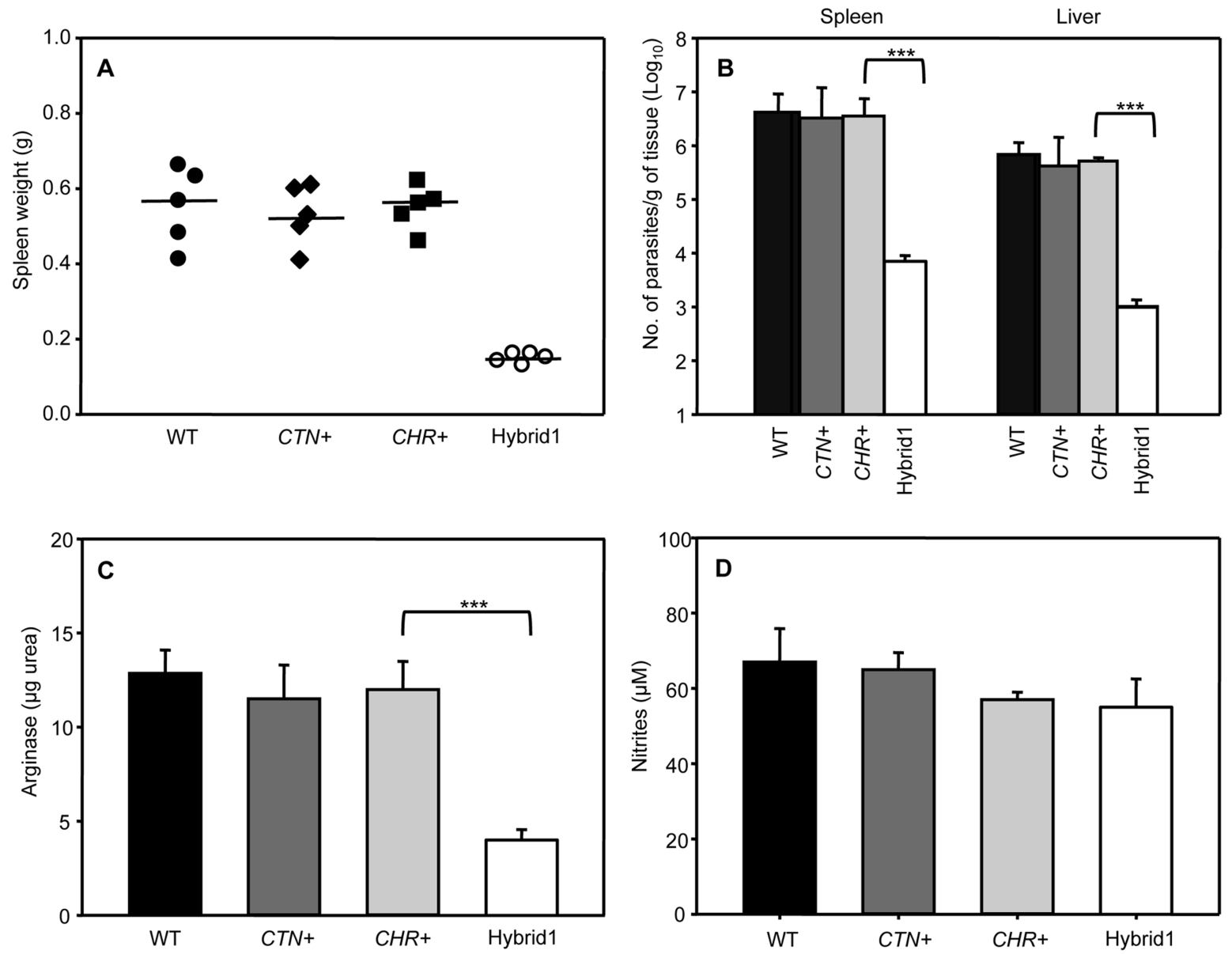

Figure 5. Reduced virulence of Hybrid1 clone. BALB/c mice were infected intraperitoneally with $2 \times 10^{6}$ (stationary phase promastigotes) WT, parental $(C T N+, C H R+)$ or Hybrid1 clones. A) Spleen weight of infected animals five weeks post-infection. B) Parasite load per gram of tissue (spleen and liver). C) Total arginase activity from spleen. D) Nitric oxide levels from cultured splenocytes. Data are presented as means \pm standard deviation and are representative of three independent experiments with similar results; ${ }^{* * *}, \mathrm{p}<0.001$.

doi:10.1371/journal.pntd.0003075.g005

particular protein expression pattern that might be impaired by ploidy. Co-infections in sand fly generate polyploid strains. However, there are no reports about the latter among clinical isolates. In Leishmania the absence of polyploids in clinical isolates can be explained by two mechanisms: loss of virulence in mice (for $4 / 5$ tetraploids [32]) and reduction to diploid stage [11]. Experiments aimed to analyze gene expression in order to determine differences associated to ploidy must clarify this question.

In summary, $L$. infantum retains the capacity of mating within its natural sand fly vector. Mating is a non-obligatory event in the cell cycle of Leishmania triggered by the presence of a unique strain in the sand fly. A clear slower virulence has been shown. It could be a positive feature for the parasite, since it allows the

\section{References}

1. Matlashewski G, Arana B, Kroeger A, Battacharya S, Sundar S, et al. (2011) Visceral leishmaniasis: elimination with existing interventions. Lancet Infect Dis 11: 322-325.

2. Tibayrenc M, Ben Abderrazak S, Guerrini F, Bañuls A (1993) Leishmania and the clonal theory of parasitic protozoa. Arch Inst Pasteur Tunis 70: 375-382.

3. Tibayrenc M, Ayala FJ (2013) How clonal are Trypanosoma and Leishmania? Trends Parasitol 29: 264-249.

4. Rougeron V, De Meeûs T, Hide M, Waleckx E, Bermudez H, et al. (2009) Extreme inbreeding in Leishmania braziliensis. Proc Natl Acad Sci USA 106: 10224-10229. transmission from cryptic hosts to vectors, spreading the disease through endemic areas.

\section{Acknowledgments}

We thank Dr. Christopher Fernández Prada, Centre de Recherche en Infectiologie du CHUL, and Dr. Carlos Garcia-Estrada (INBIOTEC) for his insightful and helpful critique in the improvement of this article.

\section{Author Contributions}

Conceived and designed the experiments: RBF RMR. Performed the experiments: EGA RAV MJ RM RMR YPP. Analyzed the data: ECA RAV RMR YPP. Contributed reagents/materials/analysis tools: ECA RAV MJ RM. Wrote the paper: RBF RMR ECA RAV.

5. Rogers MB, Hilley JD, Dickens NJ, Wilkes J, Bates PA, et al. (2011) Chromosome and gene copy number variation allow major structural change between species and strains of Leishmania. Genome Res 21: 2129-2142.

6. Rogers MB, Downing T, Smith BA, Imamura H, Sanders M, et al. (2014) Genomic confirmation of hybridisation and recent inbreeding in a vectorisolated Leishmania population. PLoS Genet 10: e1004092.

7. Mannaert A, Downing T, Imamura H, Dujardin JC (2012) Adaptive mechanisms in pathogens: universal aneuploidy in Leishmania. Trends Parasitol 28: $370-376$. 
8. Sterkers Y, Lachaud L, Bourgeois N, Crobu L, Bastien P, et al. (2012) Novel insights into genome plasticity in Eukaryotes: mosaic aneuploidy in Leishmania. Mol Microbiol 86: 15-23.

9. Tibayrenc M1, Ayala FJ. (2012) Reproductive clonality of pathogens: a perspective on pathogenic viruses, bacteria, fungi, and parasitic protozoa. Proc Natl Acad Sci U S A 109: E3305-13.

10. Akopyants NS, Kimblin N, Secundino N, Patrick R, Peters N, et al. (2009) Demonstration of genetic exchange during cyclical development of Leishmania in the sand fly vector. Science 324: 265-268.

11. Inbar E, Akopyants NS, Charmoy M, Romano A, Lawyer P, et al. (2013) The mating competence of geographically diverse Leishmania major strains in their natural and unnatural sand fly vectors. PLoS Genet 9: e1003672.

12. Sadlova J, Yeo M, Seblova V, Lewis MD, Mauricio I, et al. (2011) Visualisation of Leishmania donovani fluorescent hybrids during early stage development in the sand fly vector. PLoS One 6: e19851.

13. Bañuls AL, Hide M, Prugnolle F (2007) Leishmania and the leishmaniases: a parasite genetic update and advances in taxonomy, epidemiology and pathogenicity in humans. Adv Parasitol 64: 1-109.

14. Nolder D, Roncal N, Davies CR, Llanos-Cuentas A, Miles MA (2007) Multiple hybrid genotypes of Leishmania (Viannia) in a focus of mucocutaneous Leishmaniasis. Am J Trop Med Hyg 76: 573-578.

15. Bonfante-Garrido R, Melendez E, Barroeta S, de Alejos MA, Momen H, et al. (1992) Cutaneous leishmaniasis in western Venezuela caused by infection with Leishmania venezuelensis and $L$. braziliensis variants. Trans $\mathrm{R}$ Soc Trop Med Hyg 86: 141-148.

16. Delgado O, Cupolillo E, Bonfante-Garrido R, Silva S, Belfort E, et al. (1997) Cutaneous leishmaniasis in Venezuela caused by infection with a new hybrid between Leishmania (Viannia) braziliensis and L. (V.) guyanensis. Mem Inst Oswaldo Cruz 92: 581-582.

17. Bañuls AL, Guerrini F, Le Pont F, Barrera C, Espinel I, et al. (1997) Evidence for hybridization by multilocus enzyme electrophoresis and random amplified polymorphic DNA between Leishmania braziliensis and Leishmania panamensis/ guyanensis in Ecuador. J Eukaryot Microbiol 44: 408-411.

18. Evans DA, Kennedy WP, Elbihari S, Chapman CJ, Smith V, Peters W (1987) Hybrid formation within the genus Leishmania? Parassitologia 29: 165-173.

19. Kelly JM, Law JM, Chapman CJ, Van Eys GJ, Evans DA (1991) Evidence of genetic recombination in Leishmania. Mol Biochem Parasitol 46: 253-263.

20. Ravel C, Cortes S, Pratlong F, Morio F, Dedet JP, et al. (2006) First report of genetic hybrids between two very divergent Leishmania species: Leishmania infantum and Leishmania major. Int J Parasitol 36: 1383-1388.

21. Odiwuor S, De Doncker S, Maes I, Dujardin JC, Van der Auwera G (2011) Natural Leishmania donovani/Leishmania aethiopica hybrids identified from Ethiopia. Infect Genet Evol 11: 2113-2118.

22. Calvo-Álvarez E, Guerrero NA, Alvarez-Velilla R, Prada CF, Requena JM, et al. (2012) Appraisal of a Leishmania major strain stably expressing mCherry fluorescent protein for both in vitro and in vivo studies of potential drugs and vaccine against cutaneous leishmaniasis. PLoS Negl Trop Dis 6: e1927.

23. Goyard S, Beverley SM (2000) Blasticidin resistance: a new independent marker for stable transfection of Leishmania. Mol Biochem Parasitol 108: 249-252.
24. Robinson KA, Beverley SM (2003) Improvements in transfection efficiency and tests of RNA interference (RNAi) approaches in the protozoan parasite Leishmania. Mol Biochem Parasitol 128: 217-228.

25. Sacks DL, Perkins PV (1984) Identification of an infective stage of Leishmania promastigotes. Science 223: 1417-1419.

26. Titus RG, Marchand M, Boon T, Louis JA (1985) A limiting dilution assay for quantifying Leishmania major in tissues of infected mice. Parasite Immunol 7: 545-555.

27. Reguera RM, Balaña-Fouce R, Showalter M, Hickerson S, Beverley SM (2009) Leishmania major lacking arginase (ARG) are auxotrophic for polyamines but retain infectivity to susceptible BALB/c mice. Mol Biochem Parasitol 165: 4856.

28. Evans TG, Thai L, Granger DL, Hibbs JB Jr (1993) Effect of in vivo inhibition of nitric oxide production in murine leishmaniasis. J Immunol 151: 907-915.

29. Peacock L, Ferris V, Bailey M, Gibson W (2009) Intraclonal mating occurs during tsetse transmission of Trypanosoma brucei. Parasit Vectors 2: 43.

30. Gibson W, Garside L, Bailey M (1992) Trisomy and chromosome size changes in hybrid trypanosomes from a genetic cross between Trypanosoma brucei rhodesiense and T. b. brucei. Mol Biochem Parasitol 51: 189-199.

31. Gibson W, Peacock L, Ferris V, Williams K, Bailey M (2008) The use of yellow fluorescent hybrids to indicate mating in Trypanosoma brucei. Parasit Vectors 1, 4.

32. Hope M, MacLeod A, Leech V, Melville V, Sasse J, et al. (1999) Analysis of ploidy (in megabase chromosomes) in Trypanosoma brucei after genetic exchange. Mol Biochem Parasitol 104: 1-9.

33. Cruz AK, Titus R, Beverley SM (1993) Plasticity in chromosome number and testing of essential genes in Leishmania by targeting. Proc Natl Acad Sci USA 90: 1599-1603.

34. Ivens AC, Peacock CS, Worthey EA, Murphy L, Aggarwal G, et al. (2005) The genome of the kinetoplastid parasite, Leishmania major. Science 309: 436-442.

35. Heitman J (2010) Evolution of eukaryotic microbial pathogens via covert sexual reproduction. Cell Host Microbe 8: 86-99.

36. MacLeod A, Tweedie A, McLellan S, Hope M, Taylor S, et al. (2005) Allelic segregation and independent assortment in T. brucei crosses: Proof that the genetic system is Mendelian and involves meiosis. Mol Biochem Parasitol 143: 12-19.

37. Peacock L, Ferris V, Sharma R, Sunter J, Bailey M, et al. (2011) Identification of the meiotic life cycle stage of Trypanosoma brucei in the tsetse fly. Proc Natl Acad Sci USA 108: 3671-3676.

38. Peacock L, Bailey M, Carrington M, Gibson W (2014) Meiosis and haploid gametes in the pathogen Trypanosoma brucei. Curr Biol 24: 181-186.

39. Abebe T, Hailu A, Woldeyes M, Mekonen W, Bilcha K, et al. (2012) Local increase of arginase activity in lesions of patients with cutaneous leishmaniasis in Ethiopia. PLoS Negl Trop Dis 6: e1684.

40. Ibrahim AS, Magee BB, Sheppard DC, Yang M, Kauffman S, et al. (2005) Effects of ploidy and mating type on virulence of Candida albicans. Infect Immun 73: 7366-7374. 

RESULTADOS Y DISCUSIÓN 


\section{RESULTADOS Y DISCUSIÓN}

El empleo de parásitos modificados genéticamente que sobreexpresan proteínas fluorescentes o bioluminiscentes, supone un avance vital en el estudio de las enfermedades causadas por tripanosomátidos. En la actualidad, estos microorganismos transgénicos se emplean en el cribado de miles de nuevos compuestos según los sistemas de alto rendimiento o HTS. Otra aplicación de dichos parásitos modificados es la de realizar infecciones experimentales, la cual presenta la ventaja de reducir drásticamente el número de animales empleados en los estudios preclínicos. Finalmente, el uso de parásitos fluorescentes está contribuyendo notablemente al entendimiento de los mecanismos de intercambio genético que tienen lugar en los parásitos del género Leishmania, en T. brucei y en T. cruzi; la importancia de este fenómeno radica en que puede ser la causa de la transferencia de caracteres tales como la virulencia, el tropismo tisular y la resistencia a fármacos, además de la aparición de nuevas cepas.

\subsection{ARTÍCULO 1: "Gimatecan and other camptothecin derivatives poison Leishmania DNA-topoisomerase IB leading to a strong leishmanicidal effect"}

Uno de los aspectos más preocupantes de las enfermedades causadas por los parásitos del género Leishmania es la rapidez de aparición de cepas resistentes contra los fármacos empleados en la actualidad. La emergencia de estos parásitos resistentes invalida la efectividad de los tratamientos y frena el desarrollo de nuevos fármacos, por lo que la necesidad de terapias novedosas es cada vez más urgente. La farmacopea actual contra las leishmaniosis incluye derivados de los ya conocidos antimoniales pentavalentes, al igual que el empleo de anfotericina $\mathrm{B}$ o paromomicina (Berman, 2005), los cuales presentan efectos secundarios indeseables o requieren de tratamientos largos y administraciones por vía parenteral, lo que dificulta la adherencia a los tratamientos (Croft y Olliaro, 2011). La búsqueda de dianas diferenciales entre el parásito y el hospedador es una estrategia ampliamente empleada para el diseño de nuevos fármacos. La ADN topoisomerasa IB de Leishmania (TopIB), debido a su estructura dimérica en contraste con la enzima monomérica humana (Villa y col., 2003), aparece como una de las dianas preferenciales en la quimioterapia actual contra la leishmaniosis (Reguera y col., 2006). Esta característica es común a otros tripanosomátidos, como T. cruzi y T. brucei (Bodley y col., 2003). La camptotecina, un alcaloide con actividades antitumorales extraído del árbol Camptotheca acuminata, y sus derivados, son venenos de la TopIB, los cuales desarrollan su función al unirse de forma específica y reversible al complejo ADN-TopIB (Hertzberg y col., 1989). Este artículo describe la actividad leishmanicida, tanto in vitro como ex vivo, de la camptotecina y tres análogos empleados en la terapia contra el cáncer: topotecan (Hycantim ${ }^{\circledR}$ ), gimatecan (ST1481) y el pro-fármaco irinotecan (Camptostar ${ }^{\circledR}$ ), al igual que su metabolito activo SN-38, contra L. infantum.

La actividad de la camptotecina y sus derivados fue estudiada sobre promastigotes de L. infantum modificados genéticamente para expresar de forma estable la 
proteína infrarroja IFP 1.4 (Shu y col., 2009), y sobre un modelo ex vivo de esplenocitos murinos infectados con amastigotes de la misma cepa fluorescente. El gimatecan y la camptotecina fueron los compuestos que exhibieron una capacidad mayor para inhibir el crecimiento de los promastigotes extracelulares de $L$. infantum-IFP 1.4. Ensayos in vitro específicos demostraron que todos los fármacos empleados eran venenos de la TopIB, y entre ellos, el gimatecan destacó como el inhibidor más potente de la relajación del ADN superenrrollado, comprobándose su papel como veneno de la TopIB de Leishmania.

El modelo ex vivo de esplenocitos murinos infectados con la cepa L. infantum-IFP 1.4, permite el estudio de la actividad de compuestos y fármacos bajo unas condiciones que mimetizan al máximo la situación in vivo, al presentar la totalidad de las células inmunes del órgano infectado, incluyendo los macrófagos infectados y los fibroblastos (Balaña-Fouce y col., 2012). La actividad citotóxica de todos los compuestos sobre los esplenocitos infectados se situó en el rango nanomolar, a excepción del irinotecan (>100 mM), el cual parece no metabolizarse a SN-38 en el explante ex vivo. La forma amastigote presentó una mayor sensibilidad a los venenos de la TopIB que las formas extracelulares, obteniéndose índices terapéuticos más elevados. Este no es un resultado inesperado ya que muchos compuestos dirigidos a distintas dianas intracelulares tienen un comportamiento similar (Coombs y col., 1983).

Un resultado destacable es el gran potencial del gimatecan en todos los ensayos llevados a cabo, tanto in vitro como ex vivo. Este fármaco tiene un índice selectivo superior a 170, tres veces superior a la miltefosina, la cual se emplea actualmente en el tratamiento de la leishmaniosis. Además, el gimatecan presenta algunas características muy positivas que podrían convertirlo en un fármaco de interés para el tratamiento de la LV: i) tras su administración oral, los niveles más elevados se encuentran en el bazo y el hígado (Dallavalle y col., 2000); ii) el porcentaje de la forma activa en plasma se encuentra en torno al $80-100 \%$, superando significativamente al topotecan, el irinotecan y el SN-38, con unos porcentajes cercanos al 20\% (Zhu y col., 2009; Burke y col., 1995); iii) posee una vida media de 76,5 h, manteniendo concentraciones en plasma 7 días después de su administración (Zhu y col., 2009); iv) Zhu y colaboradores (2009), demostraron las propiedades farmacocinéticas favorables del gimatecan en pacientes enfermos de cáncer tras una administración oral semanal durante tres semanas $(1,2 \mathrm{mg} / \mathrm{Kg})$. La miltefosina, a pesar de su seguridad, requiere de una administración oral durante 28 días $(1,76 \mathrm{mg} / \mathrm{Kg} /$ día), para conseguir un tratamiento eficaz contra la LC, lo que dificulta la adherencia al tratamiento (Dorlo y col., 2008); v) a diferencia de otras camptotecinas, el gimatecan parece presentar unas mejores características farmacocinéticas en humanos que en ratones (Burke y col., 1995); vi) además, se ha demostrado que este fármaco no se ve afectado por la proteína resistente a fármacos (MDR-1), responsable de la resistencia a camptotecina, la cual posee un gen ortólogo en Leishmania (Teicher, 2008). Por tanto, los derivados de la camptotecina son venenos de la TopIB y son capaces de reducir la carga parasitaria del cultivo ex vivo, destacando el gimatecan como el más eficiente entre los análogos analizados, y su elevado índice selectivo lo convierte en un fármaco potencial contra la LV. 
En este sentido, este artículo es una primera aproximación del empleo de parásitos modificados genéticamente que sobreexpresan proteínas fluorescentes para el cribado de miles de nuevos compuestos en sistemas HTS. Este sistema facilita y acelera el descubrimiento de nuevos fármacos, ya que permite identificar "hits" potenciales, además de validar y optimizar el proceso de identificación. Los "screenings" basados en el empleo de proteínas fluorescentes presentan la ventaja de poder contar con un gran número de réplicas que aseguran la uniformidad entre los pocillos y la reproducibilidad del experimento. En nuestro caso se empleó una cepa modificada de L. infantum para que expresara de forma estable la proteína infrarroja IFP 1.4 en todas las etapas del ciclo vital del parásito. El sistema HTS empleado fue el uso de esplenocitos infectados de ratones BALB/c y placas de 96 pocillos. Además de utilizar la forma relevante de la enfermedad, el amastigote intracelular, el modelo ex vivo mimetiza al máximo la inmunopatología de la enfermedad, al incluir todas las poblaciones celulares del órgano infectado. Tras la adición del compuesto sobre el cultivo ex vivo, éste permanece en contacto con las células $72 \mathrm{~h}$, tiempo durante el cual se realizan mediciones de la misma placa de microtítulo para calcular finalmente la actividad leishmanicida del fármaco en cuestión.

Como se ha comentado recientemente, los tratamientos terapéuticos contra las enfermedades causadas por tripanosomatidos tratan de dirigirse específicamente contra las formas intracelulares de la enfermedad. Sereno y colaboradores (2001), establecieron la actividad leishmanicida de dos fármacos empleados en clínica, la pentamidina y el Glucantime ${ }^{\circledR}$, por medio de una cepa bioluminiscente de $L$. amazonensis. Este grupo concluyó que ambos compuestos eran más efectivos en macrófagos infectados que sobre amastigotes axénicos. Lang y colaboradores (2005), mostraron resultados muy prometedores de la efectividad de la anfotericina $\mathrm{B}$, la pentamidina y otros derivados en infecciones de macrófagos aislados de médula ósea de ratón con una cepa de L. amazonensis que expresaba la luciferasa de P. pyralis. Por otra parte, una cepa de L. donovani que expresaba la GFP y que había sido obtenida desde aislados clínicos de pacientes resistentes y sensibles a Glucantime ${ }^{\circledR}$, fueron empleadas para infectar monocitos J744.1. Los amastigotes procedentes de la cepa resistente mostraron sensibilidad a miltefosina, pentamidina, paromomicina y anfotericina B, aunque seguían siendo resistentes a los antimoniales pentavalentes tras la manipulación genética.

Idealmente, las plataformas HTS deberían mimetizar las condiciones naturales encontradas por los parásitos en el interior del hospedador mamífero. Kram y colaboradores (2008), desarrollaron un test para diferenciar si el efecto antiLeishmania se debía a la actividad leishmanicida de forma directa, o a funciones indirectas como consecuencia de la activación de los macrófagos. Este método combinaba el uso de una cepa de L. major que sobreexpresaba la GFP con análisis por FACS, además de utilizar el yoduro de propidio y la cuantificación del óxido nítrico liberado. Debido al fuerte impacto de la respuesta inmune del hospedador sobre el tratamiento de la leishmaniosis, los explantes ex vivo establecidos desde los órganos de animales infectados con cepas de parásitos transgénicos, aparecen como la mejor opción para recrear el microambiente en el vector definitivo. Esta es la metodología seguida en este artículo, la cual había sido validada en explantes derivados de bazos de hámsteres sirios infectados con una cepa de L. donovani que expresaba la luciferasa de luciérnaga; además, el sistema fue empleado para testar 
una librería compuesta por miles de compuestos contra la LV (Osorio y col., 2011). Recientemente, el mismo grupo ha validado el empleo de explantes ex vivo de ganglios linfáticos infectados con una cepa bioluminiscente de L. major (Peniche y col., 2014).

\subsection{ARTÍCULO 2: "Appraisal of a Leishmania major strain stably expressing mCherry fluorescent protein for both in vitro and in vivo studies of potential drugs and vaccine against cutaneous leishmaniasis"}

Los parásitos modificados genéticamente que sobreexpresan proteínas reporteras fluorescentes se han convertido en herramientas esenciales para realizar estudios HTS (Dube y col., 2009), y para entender los mecanismos de la patogénesis de la enfermedad in vivo (Lang y col., 2009). Aunque la GFP es uno de los reporteros fluorescentes más empleados, la aparición de variantes de la misma y otras proteínas fluorescentes aisladas de otros organismos ha permitido cubrir prácticamente todas las longitudes de onda del espectro visible. De entre ellas, destacan aquéllas cuyo pico de emisión se encuentra en la zona roja del espectro, como la proteína mCherry empleada en este estudio. La absorción de la luz por los tejidos en la región roja y roja lejana del espectro se reduce y, por consiguiente, la penetración se ve aumentada (Lin y col., 2009). Además, la proteína monomérica mCherry es el reportero de elección para llevar a cabo estudios in vitro e in vivo debido a su mayor fotoestabilidad en comparación con otras proteínas rojas fluorescentes como mStrawberry o el dímero DsRed (Ha y col., 1996).

La integración del gen reportero en el locus del ARNr 18S de L. major supone la estrategia más eficiente y efectiva para garantizar una expresión estable de la proteína en ausencia de la selección antibiótica, principalmente en estudios con animales (Lang y col., 2005; Pulido y col., 2012; Mißlitz y col., 2000; Mehta y col., 2008; Millington y col., 2010; Roy y col., 2000; Singh y col., 2009). La señal fluorescente de la proteína mCherry fue detectada en las distintas etapas del ciclo biológico del parásito L. major, incluida la fase intracelular, mostrando los amastigotes aislados de las lesiones una actividad dos veces menor que los promastigotes metacíclicos. Resultados similares han sido observados en distintas especies de Leishmania, en las que la expresión de la luciferasa bioluminiscente fue mucho mayor en comparación con los amastigotes de lesión y las formas intracelulares de infecciones in vitro experimentales, respectivamente (Lang y col., 2005; Roy y col., 2000). Sin embargo, Mißlitz y colaboradores (2000), obtuvieron unos niveles de expresión de la proteína EGFP hasta 10 veces superior en amastigotes que en promastigotes de L. mexicana y L. major; aunque el reportero fue integrado en el locus del ARNr $18 \mathrm{~S}$ en las dos especies, ambas diferían en la región localizada corriente abajo del gen fluorescente, cuya expresión estaba controlada por la región intergénica del gen de expresión en amastigotes cisteín proteinasa 2.8 ( $C P B$ 2.8). En el caso del trabajo de Roy y colaboradores (2000), ninguna región 3' intergénica específica de la fase intracelular fue incluida tras el gen de la luciferasa; en el presente trabajo la región intergénica del gen de la calmodulina A ( $c a m C B)$ aparece corriente abajo del gen de la proteína fluorescente mCherry en el vector pLEXSY empleado. Las secuencias intergénicas de genes regulados diferencialmente en la fase intracelular del parásito deberían ser 
incluidas en futuros vectores para obtener niveles de expresión aumentados de las proteínas reporteras en la fase amastigote. En este sentido, tecnologías como la secuenciación de ARN pueden aportar un conocimiento valioso del transcriptoma completo de los parásitos de Leishmania que puede ser empleado para mejorar los sistemas de expresión disponibles en la actualidad tanto en las formas amastigote como promastigote (Rastrojo y col., 2013; Holzer y col., 2006).

La mayoría de los "screenings" masivos de drogas en Leishmania se realizan empleando las formas extracelulares del parásito y no la forma clínica relevante, el amastigote. Los amastigotes axénicos también han sido empleados por distintos autores para testar fármacos por medio de plataformas de alto rendimiento o HTS (Sereno y col., 2001; Callahan y col., 1997; Ravinder y col., 2012). Sin embargo, "arrays" comparativos de expresión en amastigotes axénicos y amastigotes aislados de macrófagos infectados presentan importantes diferencias metabólicas, alteraciones en el transporte intracelular y una respuesta modificada al estrés oxidativo (Rochette y col., 2009). La disponibilidad de una cepa transgénica de $L$. major que expresa la proteína fluorescente mCherry (mCherry+L. major), permite la evaluación de la actividad leishmanicida de distintos compuestos en la fase amastigote del parásito, lo cual ha sido demostrado en este trabajo mediante el empleo de tres fármacos de uso clínico contra la leishmaniosis: la anfotericina B, la paromomicina y la miltefosina. El principal reportero para el testado de drogas en Leishmania spp. ha sido la GFP, aunque esta metodología ha puesto de manifiesto la necesidad de ensayos más precisos y sensibles para obtener resultados fiables, haciéndose necesario en algunos casos análisis por citometría de flujo (Sereno y col., 2007). Bilbao-Ramos y colaboradores (2012), desarrollaron un método para establecer la actividad leishmanicida potencial de distintos compuestos en amastigotes de Leishmania, mediante el empleo de la resazurina (un tinte fluorescente con un pico de emisión en la zona roja del espectro) en placas de microtitulación. A diferencia de los parásitos que expresan la GFP, la emisión de la proteína mCherry, también en la zona roja del espectro, permite un nivel de sensibilidad suficiente para detectar $10^{4}$ amastigotes aislados desde lesión, lo que evidencia los beneficios de este reportero sobre otras proteínas fluorescente para su uso en sistemas de testado de fármacos HTS.

Otra ventaja de las proteínas fluorescentes es su empleo en estudios dinámicos que permiten analizar la eficiencia de los fármacos en la misma placa de microtítulo a distintos tiempos. Los compuestos deben permanecer en contacto con los parásitos el tiempo suficiente para permitir que ejerzan su efecto, el cual oscila entre las 48 y las 72 horas de cultivo. Los parásitos modificados genéticamente que sobreexpresan una proteína bioluminiscente requieren de la lisis de las células y la adición de un sustrato específico, luciferina o coelenterazina, lo que hace imposible el uso de una única placa para obtener resultados a distintos tiempos.

De igual modo, este trabajo pretende destacar la importancia de las células hospedadoras empleadas en las infecciones experimentales para el testado de fármacos, ya que existen diferencias importantes en la interacción parásitohospedador entre el empleo de macrófagos peritoneales o aislados de médula ósea, y el uso de líneas celulares de monocitos humanos (Hsiao y col., 2011). La mayor parte de los ensayos en placa de microtitulación utilizan líneas celulares debido a la dificultad que supone el escalado experimental basado en cultivos primarios de 
macrófagos, además de la necesidad de un alto número de animales para llevarlo a cabo (Plock y col., 2001; Dube y col., 2005; Ashutosh y col., 2005; Singh y col., 2009; Pulido y col., 2012; Siqueira-Neto y col., 2012). Por tanto, el empleo de una combinación de distintas aproximaciones que incluyan el uso de promastigotes, amastigotes intracelulares y cultivos celulares primarios, permitiría identificar compuestos interesantes a través de "screenings" masivos de fármacos leishmanicidas (De Muylder y col., 2011; Balaña-Fouce y col., 2012).

La manipulación de grandes cantidades de fármacos potenciales requiere tests fáciles de realizar y cuantificar y que sean reproducibles, pero además deben mimetizar las condiciones naturales en la célula hospedadora. Debido a la gran influencia de la respuesta inmune en el tratamiento de la leishmaniosis, las futuras aproximaciones de estudios HTS deberían incluir el ambiente inmunopatológico encontrado en el sitio de interacción del parásito y las células del huésped (Osorio y col., 2011; Balaña-Fouce y col., 2012; Prada y col., 2013; Peniche y col., 2014). Las principales ventajas del empleo de la cepa mCherry+L. major son la automatización y la miniaturización de los experimentos, ya que los ensayos se realizan en placas de 96 pocillos, lo que reduce los costes de los reactivos. Además, se eliminan pasos tediosos como la tinción de las células o la lisis de las mismas, y permite realizar estudios cinéticos a lo largo del tiempo del ensayo en la misma placa de cultivo.

Debido a que la integración estable de proteínas reporteras en el genoma del parásito es una estrategia valiosa para llevar a cabo infecciones en animales a tiempo real (Lang y col., 2005; Lecoeur y col., 2007; Lecoeur y col., 2010; Roy y col., 2000; Thalhofer y col., 2010; Latorre-Esteves y col., 2010), la cepa modificada mCherry $+L$. major fue empleada para infectar las almohadillas plantares de ratones BALB/c susceptibles, resultando en lesiones crónicas y destructivas en el lugar de la inyección. Además, esta aproximación supone una mejora bioética importante, ya que se requiere un número más reducido de animales para obtener resultados estadísticamente significantes al eliminarse las variaciones animalanimal (Lang y col., 2005). El modelo animal empleado en este estudio permitía el seguimiento de la señal fluorescente procedente de los parásitos desde la primera semana post-infección, empleando una dosis de $1 \times 10^{6}$ parásitos estacionarios, dosis empleada para inducir un desarrollo rápido de la LC. Otros modelos similares en ratones BALB/c que emplearon parásitos transfectados con la proteína EGFP y animales infectados con dosis 10 y 200 veces más elevadas, necesitaron tiempos más largos para obtener la señal verde fluorescente (Bolhassani y col., 2011; Mehta y col., 2008). El ganglio linfático drenante de la lesión no fue detectado en este estudio debido, probablemente, al inóculo empleado o al tiempo empleado para el seguimiento de la infección, tras el cual los animales fueron sacrificados. Estudios previos en los cuales se detectó emisión de los parásitos en los ganglios requirieron tiempos post-infección mucho más largos (2,5-10 meses) (Lang y col., 2005; Bolhassani y col., 2011; Mißlitz y col., 2000).

Con el fin de evaluar la idoneidad de nuestro modelo para monitorizar tratamientos in vivo, aplicamos esta aproximación para evaluar una vacuna experimental contra la leishmaniosis. Estudios previos habían confirmado que una cepa de L. infantum carente del gen codificante de la proteína de choque térmico Hsp70, HSP70-II ( $\triangle$ Hsp70-II), era capaz de conferir resistencia a una infección con 
L. major (Carrión y col., 2011; Folgueira y col., 2005). En nuestro caso, la progresión de la infección fue observada eficaz y eficientemente mediante la señal roja fluorescente emitida por los amastigotes mCherry+L. major durante 8 semanas de infección a través de un sistema de imagen a tiempo real (IVIS). La vacunación de los animales infectados resultó en una reducción de la carga parasitaria en comparación con el grupo control. Mehta y colaboradores (2008), utilizaron con éxito una aproximación similar en la que evaluaron la eficiencia de una vacuna experimental empleando una cepa de L. amazonensis que sobreexpresaba la proteína EGFP.

En comparación con los modelos de LC, y debido a la gran dificultad que supone obtener un modelo animal de LV, existe un número muy reducido de trabajos que combinen el empleo de parásitos fluorescentes o bioluminiscentes y el seguimiento de la infección en los órganos internos parasitados. Thalhofer y colaboradores (2010), fueron capaces de detectar la presencia de parásitos en el hígado y en el bazo de animales infectados durante cinco semanas con una cepa bioluminiscente de L. infantum chagasi, mostrando cómo la señal obtenida podía variar en función de la carga parasitaria, el tejido infectado, la fase de crecimiento y la viabilidad de los parásitos. Recientemente, se ha obtenido un modelo de LV empleando una cepa de L. infantum que sobreexpresaba la luciferasa de P. pyralis. Este estudio fue empleado para determinar la colonización diferencial y temporal del hígado y del bazo, además de para estudiar el efecto de la miltefosina, la cual resultó ser efectiva tras 5 días de tratamiento (Michel y col., 2011).

Existen ejemplos de estudios in vivo en otros tripanosomátidos. La generación de cepas estables fluorescentes o bioluminiscentes en el agente responsable de la enfermedad de Chagas ha tenido lugar recientemente, debido a la dificultad que ha supuesto la modificación genética del parásito y la integración de genes exógenos en el genoma de T. cruzi. En este sentido, Canavaci y colaboradores (2010), testaron varias series de compuestos que habían demostrado ser eficaces en estudios in vitro, mediante una cepa de T. cruzi bioluminiscente. Sorprendentemente, ningún compuesto, a excepción del benznidazol y el posaconazol, fue capaz de causar una reducción significativa de la infección de las almohadillas plantares inyectadas. Este resultado evidencia la ausencia de correlación proporcional, en algunos casos, entre los ensayos in vitro y los estudios preclínicos. Sin embargo, Andriani y colaboradores (2011), encontraron dos "leads" entre una librería de 23 hits identificados mediante un estudio HTS en $T$. cruzi; estos dos fármacos eran capaces de reducir la infección en más del $90 \%$ en un modelo animal empleando bioluminiscencia. De forma similar, una cepa bioluminiscente de T. brucei sirvió para comprobar la eficacia del melarsoprol y el DB829, tras tres días de tratamiento, en el área craneal de ratones CD-1 durante las etapas tardías de la enfermedad (Myburgh y col., 2013). Recientemente, el empleo de una luciferasa de P. pyralis más sensible y con un espectro de emisión desplazado hacia el rojo, ha servido para revelar la persistencia de los parásitos transgénicos de T. brucei en el sistema nervioso central, a pesar de la eliminación de la carga parasitaria en el torrente sanguíneo, el criterio clásico empleado para establecer el éxito o el fracaso del tratamiento (McLatchie y col., 2013). La detección de parásitos en sitios inesperados supone otra de las ventajas que presenta la imagen in vivo, en comparación con los métodos clásicos. Michel y colaboradores (2011), localizaron una señal biluminiscente en la grasa 
mesentérica intra-abdominal de un modelo animal bioluminiscente de LV. La ausencia señal en los animales infectados con una cepa transgénica de L. donovani sugirió que este nicho raro podía ser específico de L. infantum. El modelo in vivo ha servido también para explicar la eficacia sub-curativa de series de análogos de la adenosina en un modelo animal de tripanosomiasis africana. Estos autores encontraron un tropismo preferencial de los parásitos de T. brucei en las gónadas masculinas, estando protegidos del efecto de la droga por la barrera hematotesticular (Claes y col., 2009).

En conclusión, nuestro grupo ha desarrollado una cepa roja fluorescente de $L$. major valiosa para: i) identificar parásitos de forma individual en los tejidos animales a poder tomar fotografías mediante microscopía; ii) desarrollar fácilmente plataformas más rápidas y novedosas que permitan evaluar la actividad leishmanicida de grandes cantidades de fármacos potenciales empleando la forma clínica relevante del parásito, los amastigotes; y, iii) reproducir la infección natural en animales susceptibles debido a la virulencia de la cepa modificada, lo que incrementa la sensibilidad de la detección, especialmente en las etapas más tempranas del proceso. Además, esta aproximación está en concordancia con el principio de las Tres Erres y con la legislación actual, ya que permite reducir el número de animales empleados al poder emplear el mismo a lo largo del intervalo completo del procedimiento.

\subsection{ARTíCULO 3: "First evidence of intraclonal genetic exchange in trypanosomatids using two Leishmania infantum fluorescent transgenic clones"}

Una aplicación reciente de las proteínas fluorescentes es su empleo como biomarcadores potenciales en estudios de intercambio genético en tripanosomátidos. Durante años, la replicación clonal fue considerada como la única forma de propagación en estos protozoos parásitos. Sin embargo, existen cada vez más evidencias de que el intercambio genético intraespecífico ocurre y que, además, puede ser el responsable de la transferencia de factores de virulencia y genes de resistencia a fármacos. Los primeros genotipos híbridos fueron obtenidos mediante el uso de marcadores de resistencia antibiótica al infectar moscas tsetse con dos cepas diferentes de T. brucei (Jenni y col., 1986). Más tarde, una cepa transgénica de T. brucei que expresaba el gen de la GFP bajo el control de un represor inducible por tetraciclina, fue empleada para demostrar el intercambio genético con una cepa salvaje en las glándulas salivares del insecto, pero no en el intestino medio del mismo (Bingle y col., 2001). En otro estudio, el mismo grupo de investigación observó híbridos amarillos (como consecuencia del solapamiento de las fluorescencias roja y verde), tras la co-infección de moscas tsetse con dos cepas distintas de T. brucei que expresaban los reporteros GFP y RFP, respectivamente (Gibson y col., 2008). En Leishmania, el intercambio genético fue demostrado de forma experimental en 2009 empleando cepas de L. major que presentaban resistencia a distintos marcadores antibióticos; los clones híbridos fueron recuperados desde el vector natural de esta cepa cutánea, P. perniciosus, el cual había sido infectado con dos cepas parentales transgénicas distintas. La 
población híbrida resultante había heredado el set completo de los genes de resistencia antibiótica (Akopyants y col., 2009).

En este estudio, nuestro grupo ha aislado por primera vez híbridos intraclonales de la misma cepa de L. infantum, lo que confirma la capacidad que poseen los parásitos del género Leishmania para llevar a cabo una reproducción sexual en el interior del vector invertebrado P. perniciosus. Para ello se emplearon dos cepas parentales transgénicas de L. infantum BCN 150 que expresaban de forma estable un marcador fluorescente y otro de resistencia antibiótica diferentes; así la cepa $C H R+$ sobreexpresaba la proteína roja fluorescente mCherry y tenía resistencia a blasticidina, mientras que el otro parental denominado CTN+ expresaba la proteína verde Citrina y era resistente a higromicina. De esta manera, los dos clones híbridos recuperados presentaban una fluorescencia amarilla y resistencia a los dos antibióticos que presentaban los parentales por separado, ampliando el intercambio genético en Leishmania no sólo a las cepas cutáneas, sino también a las viscerales. Además, al generarse los híbridos amarillos desde la misma cepa de L. infantum, se abre la posibilidad de que estos parásitos sean capaces de llevar a cabo recombinación entre en mismo genotipo. El porcentaje de la población híbrida recuperada de todos los intestinos diseccionados fue del 3,4\% (2/59). Sin embargo, porcentajes no demasiado elevados habían sido obtenido en coinfecciones de especies de L. major (8-13\%) (Akopyants N.S. y col., 2009; Inbar E. y col., 2013), y hasta un 20\% (25/121) en experimentos con L. donovani (Sadlova J. y col., 2011), aunque en este último estudio ninguno de los híbridos recuperados fue viable. El bajo número de progenie híbrida aislada en el presente estudio puede evidenciar que el intercambio genético en las cepas viscerales es menos frecuente que en las cutáneas, aunque valores similares fueron obtenidos en aislados de $L$. infantum en un foco de leishmaniosis cutánea en Turquía (Rogers y col., 2014). Po ello, la explicación más razonable parece ser que el cruzamiento intraclonal es mucho menos probable que la reproducción interclonal. Estos resultados están en concordancia con los cruzamientos intraclonales obtenidos en T. brucei (Peacock y col., 2009).

Se llevaron a cabo dos co-infecciones experimentales en las moscas, realizándose las disecciones de las mismas a distintos tiempos. En la primera aproximación, las disecciones tuvieron lugar 8-11 días tras la ingesta de la sangre infectada, sin éxito en la recuperación de clones híbridos. Aunque la finalidad de este estudio no era la de analizar el tiempo necesario para la obtención de progenie híbrida, los experimentos de co-infección más cortos fueron los que generaron dos híbridos (realizando las disecciones el día 6 post-alimentación de las moscas). Otros estudios previos que emplearon L. donovani y P. perniciosus no obtuvieron híbridos viables, aunque la existencia de una progenie amarilla fluorescente fue descrita tan sólo 3 días tras la co-infección (Sadlova y col., 2011). De forma similar, Inbar y colaboradores (2013), aislaron clones híbridos tempranos (6-8 días postinfección), empleando cuatro cepas distintas de L. major en los vectores P. duboscqi y en Lutzomyia longipalpis. La frecuencia de intercambio genético en los experimentos de co-infección fue de $2-5 \times 10^{-4}$. Además, este estudio demostró que el intercambio genético no tenía barreras inter-específicas en cuanto a la permisividad de los vectores invertebrados empleados. 
En los dos híbridos obtenidos, la herencia de los cuatro marcadores parentales fue confirmada por PCR. Mediante análisis por Southern blot, la existencia de recombinación cromosómica fue puesta de manifiesto por la presencia de dos bandas de Citrina de distintos tamaños en la progenie híbrida. El menor tamaño de una de las copias puede deberse a una reorganización cromosómica fuera del locus de integración. Sin embargo, los controles de los parentales no mostraron reorganización alguna de los marcadores involucrados, sino que mantuvieron su localización en el locus del ARNr 18S. De forma complementaria, el análisis del contenido de ADN de los híbridos mostró que ambos eran triploides, en contraste con las cepas parentales, las cuales eran diploides. Aunque mediante estos métodos no se hubieran detectado aneuploidías cromosómicas, tampoco fueron detectados contenidos de material genético diploide, tetraploide o intermedios, en ninguno de los clones híbridos.

Además, el Híbrido1 fue utilizado para llevar a cabo infecciones experimentales en ratones BALB/c. Los promastigotes transformados desde amastigotes de lesión aislados de bazos infectados, presentaban un fenotipo amarillo, crecían en presencia de los dos antibióticos de selección y mantenían el contenido triploide de ADN mediante ensayos de citometría de flujo. Todo ello sirvió para evidenciar que los clones híbridos eran estables a lo largo de todo el ciclo del parásito.

Otros estudios de ploidía mediante citometría de flujo habían mostrado que la mayoría de los clones híbridos recuperados desde L. major y T. brucei eran diploides al igual que las líneas parentales, pero también se habían detectado híbridos con contenidos mayores de ADN (3n-4n) (Akopyants y col., 2009; Inbar y col., 2013; Gibson y col., 1992; Gibson y col., 2008; Hope y col., 1999). Este efecto también ha sido observado en los casos en los que se realiza un doble reemplazamiento génico para conseguir una disminución de la expresión de un gen esencial (Cruz y col., 1993). El genoma de Leishmania contiene aproximadamente 8.000 genes que codifican para proteínas, con un tamaño cercano a las $33 \mathrm{Mb}$. Un incremento de 1,5-2 en el contenido de ADN equivale a unas 16,5-33 Mb, lo que únicamente puede ser explicado mediante duplicaciones del material cromosómico, tanto de forma endógena como mediante intercambio genético. Se ha considerado que los organismos triploides se originan mediante la omisión de la reducción meiótica por una de las cepas parentales diploides, y la fusión con un gameto haploide procedente del otro progenitor (i.e. $2 n+n$ ). Por otra parte, la segregación mendeliana es conocida en T. brucei desde hace años (MacLeod y col., 2005), y recientemente han sido identificados cuatro genes específicos de meiosis que se expresan previa a la fusión celular (Peacock y col., 2011). Además, la existencia de una célula similar a un promastigote pero con un contenido haploide de ADN ha sido descrita en T. brucei, lo que ha demostrado que este organismo es esencialmente sexual (Peacock y col., 2014). Igualmente, se han identificado ortólogos de los genes específicos de meiosis en el genoma de $L$. infantum, por lo que la presencia de estos genes podría demostrar su funcionalidad en procesos meióticos en Leishmania.

La viabilidad y la virulencia del Híbrido1 de L. infantum fueron analizadas. El incremento de la actividad arginasa ha sido relacionada con un estado de enfermedad en pacientes con LV. Una reducción de L-arginina debilita la capacidad proliferativa de los linfocitos T CD4 y, por consiguiente, de producir IFN- $\gamma$ (Abebe y 
col., 2012). En este estudio, la disminución en la actividad arginasa evidenciada tanto en macrófagos humanos diferenciados THP-1 y en esplenocitos murinos infectados con el Híbrido1, sugiere un la aparición de un fenotipo con una "virulencia reducida" en la progresión de la enfermedad. En Candida albicans, se han descrito cepas triploides con una virulencia reducida en comparación con las cepas diploides isogénicas (Ibrahim y col., 2005). La adaptación de los parásitos al microambiente del hospedador mamífero supone un estado de estrés que lleva a la expresión diferencial de genes que podrían estar inhabilitados debido a los distintos estados de ploidía. Aunque se sabe que las co-infecciones en las moscas originan cepas poliploides, no existen evidencias de ello en aislados clínicos. En Leishmania, la ausencia de estas cepas poliploides en aislados de campo puede ser explicada mediante dos mecanismos: i) la pérdida de virulencia en el ratón (Hope y col., 1999) y, ii) la reducción al estado diploide (Inbar y col., 2013).

En conclusión, L. infantum posee la capacidad de reproducción sexual intraclonal en su vector flebotomino natural, generándose una progenie híbrida que heredó los complementos cromosómicos de ambos parentales. Este tipo de cruzamiento es un proceso no obligatorio en el ciclo celular de Leishmania, caracterizado por la presencia de una única cepa en la mosca. Además, el Híbrido1 mostró una virulencia reducida clara. Esto puede ser una característica positiva para el parásito, ya que permite su transmisión desde hospedadores crípticos a los vectores invertebrados, extendiéndose así la enfermedad a través de las zonas endémicas. 

CONCLUSIONES 


\section{CONCLUSIONES}

\subsection{ARTÍCULO 1: "Gimatecan and other camptothecin derivatives poison Leishmania DNA-topoisomerase IB leading to a strong leishmanicidal effect"}

1. La actividad leishmanicida de la captotecina y sus derivados fue validada en un modelo de cribado de fármacos de alto rendimiento (HTS), mediante el uso de esplenocitos murinos infectados con una cepa de L. infantum que expresa la proteína infrarroja IFP 1.4. Este cultivo ex vivo permite analizar la actividad de los compuestos bajo unas condiciones que mimetizan el microambiente del animal, ya que se incluyen todas las células inmunes encontradas en el órgano infectado.

2. Esta aproximación se puede utilizar para determinar la eficacia de compuestos candidatos contra la leishmaniosis visceral, empleando sistemas HTS que permitan la evaluación de librerías de fármacos en placas de microtitulación de 96 pocillos.

3. De entre todos los venenos de la ADN topoisomerasa IB de Leishmania analizados (TopIB), el gimatecan y la camptotecina fueron los compuestos más potentes evitando el crecimiento de los promastigotes de la cepa L. infantum-IFP 1.4 .

4. El gimatecan y la camptotecina poseían una actividad leishmanicida sobre los amastigotes infrarrojos del cultivo ex vivo en el rango nanomolar.

5. La forma amastigote mostró una mayor sensibilidad a los venenos de la TopIB (con unos índices selectivos más elevados), que los promastigotes extracelulares.

6. Los derivados de la camptotecina son capaces de reducir la carga parasitaria de los esplenocitos infectados.

7. El elevado índice selectivo del gimatecan lo convierte en un fármaco prometedor contra la leishmaniosis visceral.

\subsection{ARTÍ́CULO 2: "Appraisal of a Leishmania major strain stably expressing mCherry fluorescent protein for both in vitro and in vivo studies of potential drugs and vaccine against cutaneous leishmaniasis"}

1. La cepa de L. major que sobreexpresaba la proteína roja fluorescente mCherry fue utilizada para evaluar la actividad leishmanicida de cuatro fármacos en uso clínico contra la leishmaniosis, mediante un sistema HTS basado en la infección de macrófagos peritoneales. La cepa mCherry+L. major puede ser empleada para el descubrimiento de nuevos fármacos en la fase de amastigote.

2. Esta cepa fluorescente permitió el seguimiento in vivo del establecimiento y la progresión de la infección cutánea en ratones BALB/c. 
3. Dicha cepa transgénica fue utilizada para cuantificar la carga parasitaria a través de la medición de la fluorescencia emitida por los parásitos en las almohadillas plantares infectadas durante un periodo de 8 semanas.

4. Esta técnica fue validada in vivo mediante un ensayo de vacunación experimental con una cepa atenuada de L. infantum carente del gen codificante de la proteína de choque térmico de tipo II $(\Delta$ hsp70-II). La infección de animales con una cepa roja fluorescente de L. major para estudios de imagen a tiempo real se convierte en un método simple, más rápido, no invasivo y efectivo para establecer la progresión clínica de una infección tras una vacunación experimental o un tratamiento farmacológico.

\subsection{ARTíCULO 3: "First evidence of intraclonal genetic exchange in trypanosomatids using two Leishmania infantum fluorescent transgenic clones"}

1. La generación de dos cepas fluorescentes de L. infantum ha confirmado la existencia de un ciclo sexual no obligado en la fase extracelular del parásito al realizar co-infecciones experimentales en el vector invertebrado $P$. perniciosus.

2. Una línea híbrida fluorescente de L. infantum fue obtenida, por primera vez, a través del intercambio genético intraclonal en el interior del vector flebotomino, lo que sugiere la habilidad de este parásito de reconocer el mismo genotipo y reproducirse.

3. El cruzamiento intraclonal es un fenómeno menos frecuente que la reproducción entre cepas distintas, lo cual fue evidenciado por el bajo número de clones híbridos obtenido.

4. La progenie híbrida amarilla fluorescente fue estable a lo largo de todo el ciclo biológico del parásito, pero presentó un fenotipo de virulencia reducida, lo que fue confirmado a través de la actividad arginasa en infecciones in vitro e in vivo.

5. El intercambio genético es un proceso de vital importancia para comprender los mecanismos que controlan la transferencia de caracteres como la virulencia, el tropismo tisular o la resistencia a fármacos, al igual que la aparición de cepas nuevas en las poblaciones naturales. 


\subsection{ARTICLE 1: "Gimatecan and other camptothecin derivatives poison Leishmania DNA-topoisomerase IB leading to a strong leishmanicidal effect"}

1. The leishmanicidal activity of the camptothecin derivatives has been validated on a High Throughput Screening (HTS) model of mouse splenocytes infected with a L. infantum strain expressing IFP1.4. This ex vivo culture permits to study the compounds under conditions that resemble those found in the animal, including the presence of the complete range of immune host cells, infected macrophages and fibroblasts.

2. This approach can be employed for determining the efficacy of candidate drugs using HTS methods that allow the testing of libraries of compounds in an automated 96-well plate format.

3. Among all TopIB poisons assayed, gimatecan and camptothecin were the most powerful compounds preventing cell growth of free-living L. infantum-IFP 1.4 promastigotes within the same concentration range.

4. Gimatecan and camptothecin killed L. infantum-IFP 1.4 splenocyte-infecting amastigotes within the nanomolar range.

5. The amastigote form showed higher sensitivity to topoisomerase IB poisons (with high therapeutic selectivity indexes) than free-living promastigotes.

6. Camptothecin derivatives are suitable for reducing the parasitic burden of $e x$ vivo-infected splenocytes.

7. The selectivity index of gimatecan makes it a promising drug against visceral leishmaniasis.

\subsection{ARTICLE 2: "Appraisal of a Leishmania major strain stably expressing mCherry fluorescent protein for both in vitro and in vivo studies of potential drugs and vaccine against cutaneous leishmaniasis"}

1. A L. major strain expressing mCherry red-fluorescent protein was used to perform HTS of well-known leshmanicidal compounds in vitro by infecting peritoneal macrophages. The suitability of mCherry+L. major transgenic strain can be an important tool for drug screening in the intracellular amastigote stage.

2. This fluorescent strain enables the in vivo monitoring of the establishment and progression of cutaneous leishmaniasis in BALB/c mice.

3. This transgenic strain enabled us to quantify the parasitic load via measurement of fluorescence emission, allowing a weekly record of the infected footpads over eight weeks after the inoculation of BALB/c mice. 
4. An experimental vaccination trial based on the protection conferred by an attenuated $\Delta$ hsp70-II mutant of Leishmania was used to validate the suitability of this technique in vivo. This approach allows a simpler, faster, non-invasive and cost-effective technique to assess the clinical progression of the infection after drug or vaccine therapy.

\subsection{ARTICLE 3: "First evidence of intraclonal genetic exchange in trypanosomatids using two Leishmania infantum fluorescent transgenic clones"}

1. The generation of two L. infantum fluorescent transgenic clones permitted to confirm the existence of a non-obligate sexual cycle in the extracellular stage of the parasite within the natural sand fly vector $P$. perniciosus.

2. A L. infantum fluorescent hybrid lineage was obtained, for the first time, from intraclonal genetic exchange within the midgut of the natural vector, suggesting the ability of this parasite to recognize the same genotype and mate.

3. Intraclonal mating is more unlikely than inter-clonal mating, evidenced by the low number of hybrid progeny recovered.

4. The yellow hybrid progeny was stable throughout the whole parasite life cycle, but with a slower virulence, which correlates well with the lower arginase activity detected both in vitro and in vivo infections.

5. Genetic exchange events are of great importance for understanding the mechanisms by which traits such as virulence, tissue tropism, and drug resistance are transferred, as well as the emergence of novel strains in natural populations. 



\section{BIBLIOGRAFÍA}




\section{BIBLIOGRAFÍA}

Abebe T., Hailu A., Woldeyes M., Mekonen W., Bilcha K., Cloke T., Fry L., Seich Al Basatena NK., Corware K., Modolell M., Munder M., Tacchini-Cottier F., Müller I., Kropf P. (2012) Local increase of arginase activity in lesions of patients with cutaneous leishmaniasis in Ethiopia. PLoS Negl Trop Dis 6: e1684.

Adler S., Ber M. (1941) The transmission of Leishmania tropica by the bite of Phlebotomus papatasi. Indian J Med Res 29: 803-809.

Aguilar-Torrentera F., Laman JD., Van Meurs M., Adorini L., Muraille E., Carlieri, Y. (2002) Endogenous interleukin-12 is critical for controlling the late but not the early stage of Leishmania mexicana infection in C57BL/6 mice. Infect Immun 70: 5075-5080.

Akiyama HJ., McQuillen NK. (1972) Interaction and transformation of Leishmania donovani within in vitro cultured cells. An electron microscopical study. Am J Trop Med Hyg 21: 873-879.

Akopyants NS., Kimblin N., Secundino N., Patrick R., Peters N., Lawyer P., Dobson DE., Beverley SM., Sacks DL. (2009) Demonstration of genetic exchange during cyclical development of Leishmania in the sand fly vector. Science 324: 265-268.

Alexander J., Carter KC., Al-Fasi N., Satoskar A., Brombacher F. (2000) Endogenous IL-4 is necessary for effective drug therapy against visceral leishmaniasis. Eur J Immunol 30: 2935-2943.

Alexander J., Coombs GH., Mottram JC. (1998) Leishmania mexicana cysteine proteinase-deficient mutants have attenuated virulence for mice and potentiate a Th1 response. J Immunol 161: 6794-6801.

Ali A., Ashford RW. (1994) Visceral leishmaniasis in Ethiopia. IV. Prevalence, incidence and relation of infection to disease in an endemic area. Ann Trop Med Parasitol 88: 289-293.

Alrajhi AA., Ibrahim EA., De Vol EB., Khairat M., Faris RM., Maguire JH. (2002) Fluconazole for the treatment of cutaneous leishmaniasis caused by Leishmania major. N Engl J Med 346: 891-895.

Alvar J., Aparicio P., Aseffa A., Den Boer M., Cañavate C., Dedet JP., Gradoni L., Ter Horst R., López-Vélez R., Moreno J. (2008) The relationship between leishmaniasis and AIDS: the second 10 years. Clin Microbiol Rev 21: 334-359.

Alvar J., Cañavate C., Gutiérrez-Solar B., Jiménez M., Laguna F., López-Vélez R., Molina R., Moreno J. (1997) Leishmania and human immunodeficiency virus coinfection: the first 10 years. Clin Microbiol Rev 10: 298-319.

Alvar J., Gutiérrez-Solar B., Pachón I., Calbacho E., Ramírez M., Vallés R., Guillén JL., Cañavate C., Amela C. (1996) AIDS and Leishmania infantum. New approaches for a new epidemiological problem. Clin Dermatol 14: 541-546. 
Alvar, J. (2001) Leishmaniasis: de la biología al control. Laboratorios Intervet. 2a Edición: 200pp.

Amaral VF., Teva A., Oliveira-Neto MP., Silva AJ., Pereira MS., Cupolillo E., Porrozzi R., Coutinho SG., Pirmez C., Beverley SM., Grimaldi G Jr. (2002) Study of the safety, immunogenicity and efficacy of attenuated and killed Leishmania (Leishmania) major vaccines in a rhesus monkey (Macaca mulatta) model of the human disease. Mem Inst Oswaldo Cruz 97: 1041-1048.

Amaral VF., Teva A., Porrozzi R., Silva AJ., Pereira MS., Oliveira-Neto MP., Grimaldi G Jr. (2001) Leishmania (Leishmania) major-infected Rhesus macaques (Macaca mulatta) develop varying levels of resistance against homologous re-infections. Mem Inst Oswaldo Cruz 96: 795-804.

Ambroise-Thomas P. (2001) Parasitic diseases and immunodeficiencies. Parasitology 122 Suppl 65-71.

Ampel NM. (1991) Plagues, what's past is present: thoughts on the origin and history of new infectious diseases. Rev Infect Dis 13: 658-665.

Andersen EM., Cruz-Saldarriaga M., Llanos-Cuentas A., Luz-Cjuno M., Echevarria J., Miranda-Verastegui C., Colina O., Berman JD. (2005) Comparison of meglumine antimoniate and pentamidine for peruvian cutaneous leishmaniasis. Am J Trop Med Hyg 72: 133-137.

Andreu N., Zelmer A., Wiles S. (2011) Noninvasive biophotonic imaging for studies of infectious disease. FEMS Microbiol Rev 35: 360-394.

Andriani G., Chessler AD., Courtemanche G., Burleigh BA., Rodriguez A. (2011) Activity in vivo of anti-Trypanosoma cruzi compounds selected from a high throughput screening. PLoS Negl Trop Dis 5: e1298.

Antinori S., Schifanella L., Corbellino M. (2012) Leishmaniasis: new insights from an old and neglected disease. Eur J Clin Microbiol Infect Dis 31: 109-118.

Antony S., Agama KK., Miao ZH., Takagi K., Wright MH., Robles AI., Varticovski L., Nagarajan M., Morrell A., Cushman M., Pommier Y. (2007) Novel indenoisoquinolines NSC 725776 and NSC 724998 produce persistent topoisomerase I cleavage complexes and overcome multidrug resistance. Cancer Res 67: 10397-10405.

Ashford RW. (2000) The leishmaniases as emerging and reemerging zoonoses. Int J Parasitol 30: 1269-1281.

Ashutosh, Gupta S., Ramesh, Sundar S., Goyal N. (2005) Use of Leishmania donovani field isolates expressing the luciferase reporter gene in in vitro drug screening. Antimicrob Agents Chemother 49: 3776-3783.

Ato M., Stäger S., Engwerda CR., Kaye PM. (2002) Defective CCR7 expression on dendritic cells contributes to the development of visceral leishmaniasis. Nat Immunol 3: 1185-1191. 
Auldridge ME., Satyshur KA., Anstrom DM., Forest KT. (2012) Structure-guided engineering enhances a phytochrome-based infrared fluorescent protein. J Biol Chem 287: 7000-7009.

Aulner N., Danckaert A., Rouault-Hardoin E., Desrivot J., Helynck O., Commere PH., Munier-Lehmann H., Späth GF., Shorte SL., Milon G., Prina E. (2013) High content analysis of primary macrophages hosting proliferating Leishmania amastigotes: application to anti-leishmanial drug discovery. PLoS Negl Trop Dis 7: e2154.

Baird GS., Zacharias DA., Tsien RY. (2000) Biochemistry, mutagenesis, and oligomerization of DsRed, a red fluorescent protein from coral. Proc Natl Acad Sci USA 97: 11984-11989.

Bakshi RP., Shapiro TA. (2003) DNA topoisomerases as targets for antiprotozoal therapy. Mini Rev Med Chem 3: 597-608.

Balaña-Fouce R., Calvo-Álvarez E., Álvarez-Velilla R., Prada CF., Pérez-Pertejo Y., Reguera RM. (2012a) Role of trypanosomatid's arginase in polyamine biosynthesis and pathogenesis. Mol Biochem Parasitol 181: 85-93.

Balaña-Fouce R., García-Estrada C., Pérez-Pertejo Y., Reguera RM. (2008) Gene disruption of the DNA topoisomerase IB small subunit induces a non-viable phenotype in the hemoflagellate Leishmania major. BMC Microbiol 8: 113.

Balaña-Fouce R., Prada CF., Requena JM., Cushman M., Pommier Y., Álvarez-Velilla R., Escudero-Martínez JM., Calvo-Álvarez E., Pérez-Pertejo Y., Reguera RM. (2012b) Indotecan (LMP400) and AM13-55: two novel indenoisoquinolines show potential for treating visceral leishmaniasis. Antimicrob Agents Chemother 56: 5264-5270.

Balaña-Fouce R., Redondo CM., Pérez-Pertejo Y., Diaz-González R., Reguera RM. (2006) Targeting atypical trypanosomatid DNA topoisomerase. Drug Discov Today 11: 733-740.

Banerjee R., Kumar S., Sen A., Mookerjee A., Roy S., Pal S., Das P. (2010) TGF- $\beta$ regulated tyrosine phosphatases induce lymphocyte apoptosis in Leishmania donovani-infected hamsters. Immunol Cell Biol 89: 466-474.

Baneth G., Koutinas AF., Solano-Gallego L., Bourdeau P., Ferrer L. (2008) Canine leishmaniasis- new concepts and insights on an expanding zoonosis: part one. Trends Parasitol 24: 324-330.

Barreto-de-Souza V., Pacheco GJ., Silva AR., Castro-Faria-Neto HC., Bozza PT., Saraiva EM., Bou-Habib DC. (2006) Increased Leishmania replication in HIV-1infected macrophages is mediated by tat protein through cyclooxygenase- 2 expression and prostaglandin E2 synthesis. J Infect Dis 194: 846-854.

Basselin M., Badet-Denisot MA., Robert-Gero M. (1998) Modification of kinetoplast DNA minicircle composition in pentamidine-resistant Leishmania. Acta Trop 70: 43-61.

Bates PA. (2007) Transmission of Leishmania metacyclic promastigotes by phlebotomine sand flies. Int J Parasitol 37: 1097-1106. 
Bates PA. (2008) Leishmania sand fly interaction: progress and challenges. Curr Opin Microbiol 11: 340-344.

Beattie L., Peltan A., Maroof A., Kirby A., Brown N., Coles M., Smith DF., Kaye PM. (2010) Dynamic imaging of experimental Leishmania donovani-induced hepatic granulomas detects Kupffer cell-restricted antigen presentation to antigen-specific CD8+ T cells. PLoS Pathog 6: e1000805.

Beck JT., Ullman B. (1991) Biopterin conversion to reduced folates by Leishmania donovani promastigotes. Mol Biochem Parasitol 49: 21-28.

Belkaid Y., Kamhawi S., Modi G., Valenzuela J., Noben-Trauth N., Rowton E., Ribeiro J., Sacks DL. (1998) Development of a natural model of cutaneous leishmaniasis: powerful effects of vector saliva and saliva preexposure on the long-term outcome of Leishmania major infection in the mouse ear dermis. J Exp Med 188: 1941-1953.

Belkaid Y., Mendez S., Lira R., Kadambi N., Milon G., Sacks D. (2000) A natural model of Leishmania major infection reveals a prolonged "silent" phase of parasite amplification in the skin before the onset of lesion formation and immunity. J Immunol 165: 969-77.

Belli AA., Miles MA., Kelly JM. (1994) A putative Leishmania panamensis/Leishmania braziliensis hybrid is a causative agent of human cutaneous leishmaniasis in Nicaragua. Parasitology 109: 435-442.

Bentwich Z. (2003) Concurrent infections that rise the HIV viral load. J HIV Ther 8: 72-75.

Berman J. (2005) Clinical status of agents being developed for leishmaniasis. Expert Opin Investig Drugs 14: 1337-1346.

Bernier R., Turco SJ., Olivier M., Tremblay M. (1995) Activation of human immunodeficiency virus type 1 in monocytoid cells by the protozoan parasite Leishmania donovani. J Virol 69: 7282-7285.

Besteiro S., Williams RA., Coombs GH., Mottram JC. (2007) Protein turnover and differentiation in Leishmania. Int J Parasitol 37: 1063-1075.

BIBLIOGRAFÍA

Bilbao-Ramos P., Sifontes-Rodríguez S., Dea-Ayuela MA., Bolás-Fernández F. (2012) A fluorometric method for evaluation of pharmacological activity against intracellular Leishmania amastigotes. J Microbiol Methods 89: 8-11.

Bingle LE., Eastlake JL., Bailey M., Gibson WC. (2001) A novel GFP approach for the analysis of genetic exchange in trypanosomes allowing the in situ detection of mating events. Microbiology 147: 3231-3240.

Blackwell JM., Goswami T., Evans CAW., Sibthorpe D., Papo N., White JK, Searle S., Miller EN., Peacock CS., Mohammed H., Ibrahim M. (2001) SLC11A1 (formely NRAMP1) and disease resistance. Cell Microbiol 3: 773-784. 
Blanchette J., Abu-Dayyeh I., Hassani K., Whitcombe L., Olivier M. (2009) Regulation of macrophage nitric oxide production by the protein tyrosine phosphatase Src homology 2 domain phosphotyrosine phosphatase 1 (SHP-1). Immunology 127: 123-133.

Bodley AL., Chakraborty AK., Xie S., Burri C., Shapiro TA. (2003) An unusual type IB topoisomerase from African trypanosomes. Proc Natl Acad Sci USA 100: 75397544.

Bolhassani A., Taheri T., Taslimi Y., Zamanilui S., Zahedifard F., Seyed N., Torkashvand F., Vaziri B., Rafati S. (2011) Fluorescent Leishmania species: development of stable GFP expression and its application for in vitro and in vivo studies. Exp Parasitol 127: 637-645.

Boulanger N., Lowenberger C., Volf P., Ursic R., Sigutova L., Sabatier L., Svobodova M., Beverley SM., Späth G., Brun R., Pesson B., Bulet P. (2004) Characterization of a defensin from the sand fly Phlebotomus duboscqi induced by challenge with bacteria or the protozoan parasite Leishmania major. Infect Immun 72: 7140-7146.

Bringmann G., Thomale K., Bischof S., Schneider C., Schultheis M., Schwarz T., Moll H., Schurigt U. (2013) A novel Leishmania major amastigote assay in 96-well format for rapid drug screening and its use for discovery and evaluation of a new class of leishmanicidal quinolinium salts. Antimicrob Agents Chemother 57: 30033011.

Brittingham A., Morrison CJ., McMaster WR., McGwire BS., Chang KP., Mosser DM. (1995) Role of the Leishmania surface protease gp63 in complement fixation, cell adhesion, and resistance to complement-mediated lysis. J Immunol 155: 31023111.

Broderson JR., Chapman Jr WL., Hanson WL. (1986) Experimental visceral leishmaniasis in the owl monkey. Vet Pathol 23: 293-302.

Bronstein I., Fortin J., Stanley PE., Stewart GS., Kricka LJ. (1994) Chemiluminescent and bioluminescent reporter gene assays. Anal Biochem 219: 169-81.

Bryan CP. (1974) Ancient Egyptian Medicine: The Papyrus Ebers. ISBN-13: 9780890050040.

Burke TG., Munshi CB., Mi Z., Jiang Y. (1995) The important role of albumin in determining the relative human blood stabilities of the camptothecin anti-cancer drugs. J Pharm Sci 84: 518-519.

Bustamante JM., Park HJ., Tarleton RL., The Chagas Drug Discovery Consortium. (2011) Report of the 2nd Chagas Drug Discovery Consortium meeting, held on 3 November 2010; Atlanta GA, USA. Expert Opin Drug Discov 6: 965-973.

Callahan HL., Portal AC., Devereaux R., Grogl M. (1997) An axenic amastigote system for drug screening. Antimicrob Agents Chemother 41: 818-822.

Campbell RE., Tour O., Palmer AE., Steinbach PA., Baird GS., Zacharias DA., Tsien RY. (2002) A monomeric red fluorescent protein. Proc Natl Acad Sci USA 99: 78777882. 
Canavaci AM., Bustamante JM., Padilla AM., Perez Brandan CM., Simpson LJ., Xu D., Boehlke CL., Tarleton RL. (2010) In vitro and in vivo high-throughput assays for the testing of anti-Trypanosoma cruzi compounds. PLoS Negl Trop Dis 4: e740.

Carrión J., Folgueira C., Soto M., Fresno M., Requena JM. (2011) Leishmania infantum HSP70-II null mutant as candidate vaccine against leishmaniasis: a preliminary evaluation. Parasit Vectors 4: 150.

Carter CR., Whitcomb JP., Campbell JA., Mukbel RM., McDowell MA. (2009) Complement receptor 3 deficiency influences lesion progression during Leishmania major infection in BALB/c mice. Infect Immun 77: 5668-5675.

Chakravarty J., Kumar S., Trivedi S., Rai VK., Singh A., Ashman JA., Laughlin EM., Coler RN., Kahn SJ., Beckmann AM., Cowgill KD., Reed SG., Sundar S., Piazza FM. (2011) A clinical trial to evaluate the safety and immunogenicity of the LEISHF1+MPL-SE vaccine for use in the prevention of visceral leishmaniasis. Vaccine 29: 3531-3537.

Chalfie M., Tu Y., Euskirchen G., Ward WW., Prasher DC. (1994) Green fluorescent protein as a marker for gene expression. Science 263: 802-805.

Chan MM., Bulinski JC., Chang KP., Fong D. (2003) A microplate assay for Leishmania amazonensis promastigotes expressing multimeric green fluorescent protein. Parasitol Res 89: 266-271.

Chandra D., Naik S. (2008) Leishmania donovani infection down-regulates TLR2stimulated IL-12p40 and activates IL-10 in cells of macrophage/monocytic lineage by modulating MAPK pathways through a contact-dependent mechanism. Clin Exp Immunol 154: 224-234.

Chang KP. (1978) Leishmania infection of human skin fibroblasts in vitro: absence of phagolysosomal fusion after induced phagocytosis of promastigotes, and their intracellular transformation. Am J Trop Med Hyg 27: 1084-1096.

Chappuis F., Sundar S., Hailu A., Ghalib H., Rijal S., Peeling RW., Alvar J., Boelaert M. (2007) Visceral leishmaniasis: what are the needs for diagnosis, treatment and control? Nat Rev Microbiol 5: 873-882.

Charest H., Matlashewski G. (1994) Developmental gene expression in Leishmania donovani: differential cloning and analysis of an amastigote-stage-specific gene. Mol Cell Biol 14: 2975-2984.

Chirac P., Torreele E. (2006) Global framework on essential health R\&D. Lancet 367: 1560-1561.

Ciaramella P., Oliva G., Luna RD., Gradoni L., Ambrosio R., Cortese L., Scalone A., Persechino A. (1997) A retrospective clinical study of canine leishmaniasis in 150 dogs naturally infected by Leishmania infantum. Vet Rec 141: 539-543.

Claes F., Vodnala SK., van Reet N., Boucher N., Lunden-Miguel H., Baltz T., Goddeeris BM., Büscher P., Rottenberg ME. (2009) Bioluminescent imaging of Trypanosoma brucei shows preferential testis dissemination which may hamper drug efficacy in sleeping sickness. PLoS Negl Trop Dis 3: e486. 
Coelho AC., Leprohon P., Ouellette M. (2012) Generation of Leishmania hybrids by whole genomic DNA transformation. PLoS Negl Trop Dis 6: e1817.

Coelho AC., Messier N., Ouellette M., Cotrim PC. (2007) Role of the ABC transporter PRP1 (ABCC7) in pentamidine resistance in Leishmania amastigotes. Antimicrob Agents Chemother 51: 3030-3032.

Coler RN., Goto Y., Bogatzki L., Raman V., Reed SG. (2007) Leish-111f, a recombinant polyprotein vaccine that protects against visceral leishmaniasis by elicitation of CD4+ T cells. Infect Immun 75: 4648-4654.

Coler RN., Reed SG. (2005) Second-generation vaccines against leishmaniasis. Trends Parasitol 21: 244-249.

Convit J., Ulrich M., Polegre MA., Avila A., Rodríguez N., Mazzedo MI., Blanco B. (2004) Therapy of Venezuelan patients with severe mucocutaneous or early lesions of diffuse cutaneous leishmaniasis with a vaccine containing pasteurized Leishmania promastigotes and bacillus Calmette-Guerin: preliminary report. Mem Inst Oswaldo Cruz 99: 57-62.

Coombs GH., Hart DT., Capaldo J. (1983) Leishmania mexicana: drug sensitivities of promastigotes and transforming amastigotes. J Antimicrob Chemother 11: 151162.

Corona P., Gibellini F., Cavalli A., Saxena P., Carta A., Loriga M., Luciani R., Paglietti G., Guerrieri D., Nerini E., Gupta S., Hannaert V., Michels PA., Ferrari S., Costi PM. (2012) Structure-based selectivity optimization of piperidine-pteridine derivatives as potent Leishmania pteridine reductase inhibitors. J Med Chem 55: 8318-8329.

Coulson RM., Smith DF. (1990) Isolation of genes showing increased or unique expression in the infective promastigotes of Leishmania major. Mol Biochem Parasitol 40: 63-75.

Courret N., Prina E., Mougneau E., Saraiva EM., Sacks DL., Glaichenhaus N., Antoine JC. (1999) Presentation of the Leishmania antigen LACK by infected macrophages is dependent upon the virulence of the phagocytosed parasites. Eur J Immunol 29: 762-773.

Cox FE. (2002) History of human parasitology. Clin Microbiol Rev 15: 595-612.

Croft SL., Olliaro P. (2011) Leishmaniasis chemotherapy: challenges and opportunities. Clin Microbiol Infect 17: 1478-1483.

Croft SL., Sundar S., Fairlamb AH. (2006) Drug resistance in leishmaniasis. Clin Microbiol Rev 19: 111-126.

Cruz AK., Titus R., Beverley SM. (1993) Plasticity in chromosome number and testing of essential genes in Leishmania by targeting. Proc Natl Acad Sci USA 90: 1599-1603.

Cruz I., Morales MA., Noguer I., Rodríguez A., Alvar J. (2002) Leishmania in discarded syringes from intravenous drug users. Lancet 359: 1124-1125. 
Cruz I., Nieto J., Moreno J., Cañavate C., Desjeux P., Alvar J. (2006) Leishmania/HIV co-infections in the second decade. Indian J Med Res 123: 357-388.

Culley FJ., Harris RA., Kaye PM., McAdam KP., Raynes JG. (1996) C-reactive protein binds to a novel ligand on Leishmania donovani and increases uptake into human macrophages. J Immunol 156: 4691-4696.

Cunningham DD. (1885) On the presence of peculiar parasitic organisms in the tissue of a specimen of Delhi boil. Sci Mem Med Offic Army India 1: 21-31.

Cunningham ML., Titus RG., Turco SJ., Beverley SM. (2001) Regulation of differentiation to the infective stage of the protozoan parasite Leishmania major by tetrahydrobiopterin. Science 292: 285-287.

Curret N., Fréhel C., Gouhier N., Pouchelet M., Prina E., Roux P., Antoine JC. (2002) Biogenesis of Leishmania-harbouring parasitophorous vacuoles following phagocytosis of the metacyclic promastigote or amastigote stages of the parasites. J Cell Sci 115: 2303-2316.

da Silva RA., Tavares NM., Costa D., Pitombo M., Barbosa L., Fukutani K., Miranda JC., de Oliveira CI., Valenzuela JG., Barral A., Soto M., Barral-Netto M., Brodskyn C. (2011) DNA vaccination with KMP11 and Lutzomyia longipalpis salivary protein protects hamsters against visceral leishmaniasis. Acta Trop 120: 185-190.

da Silva RP., Hall BF., Joiner KA., Sacks DL. (1989) CR1, the C3b receptor, mediates binding of infective Leishmania major metacyclic promastigotes to human macrophages. J Immunol 143: 617-622.

Dallavalle S., Delsoldato T., Ferrari A., Merlini L., Penco S., Carenini N., Perego P., De Cesare M., Pratesi G., Zunino F. (2000) Novel 7-substituted camptothecins with potent antitumor activity. J Med Chem 43: 3963-3969.

Dantas-Torres F. (2009) Canine leishmaniosis in South America. Parasit Vectors 2(Suppl 1): S1.

Das S., Pandey K., Kumar A., Sardar AH., Purkait B., Kumar M., Kumar S., Ravidas VN., Roy S., Singh D., Das P. (2012) TGF- $\beta 1$ re-programs TLR4 signaling in $L$. donovani infection: enhancement of SHP-1 and ubiquitin-editing enzyme A20. Immunol Cell Biol 90: 640-654.

Das VN., Ranjan A., Sinha AN., Verma N., Lal CS., Gupta AK., Siddiqui NA., Kar SK. (2001) A randomized clinical trial of low dosage combination of pentamidine and allopurinol in the treatment of antimony unresponsive cases of visceral leishmaniasis. J Assoc Physicians India 49: 609-613.

David CV., Craft N. (2009) Cutaneous and mucocutaneous leishmaniasis. Dermatol Ther 22: 491-502.

de Almeida MC., Vilhena V., Barral A., Barral-Netto M. (2003) Leishmanial infection: analysis of its first steps. A review. Mem Inst Oswaldo Cruz 98: 861-870.

de Campos SN., Souza-Lemos C., Teva A., Porrozzi R., Grimaldi G Jr. (2010) Systemic and compartmentalised immune responses in a Leishmania braziliensis-macaque 
model of self-healing cutaneous leishmaniasis. Vet Immunol Immunopathol 137: 149-154.

de Leo FR., Ulman KV., Davis AR., Jutila KL., Quinn MT. (1996) Assembly of the human neutrophil NADPH oxidase involves binding of p67phox and flavocytochrome $b$ to a common functional domain in p47phox. J Biol Chem 271: 17013-17020.

De Muylder G., Ang KK., Chen S., Arkin MR., Engel JC., McKerrow JH. (2011) A screen against Leishmania intracellular amastigotes: comparison to a promastigote screen and identification of a host cell-specific hit. PLoS Negl Trop Dis 5: e1253.

de Veer MJ., Curtis JM., Baldwin TM., DiDonato JA., Sexton A., McConville MJ., Handman E., Schofield L. (2003) MyD88 is essential for clearance of Leishmania major: possible role for lipophosphoglycan and Toll-like receptor 2 signaling. Eur J Immunol 33: 2822-2831.

Deniau M., Cañavate C., Faraut-Gambarelli F., Marty P. (2003) The biological diagnosis of leishmaniasis in HIV-infected patients. Ann Trop Med Parasitol 97 Suppl 1: 115-133.

Dennis VA., Lujan R., Chapman WL Jr., Hanson WL. (1986) Leishmania donovani: cellular and humoral immune responses after primary and challenge infections in squirrel monkeys, Saimiri sciureus. Exp Parasitol 61: 319-334.

Descoteaux A., Turco SJ. (1999) Glycoconjugates in Leishmania infectivity. Biochim Biophys Acta 1455: 341-352.

Desjeux P. (2004) Leishmaniasis: current situation and new perspectives. Comp Immunol Microbiol Infect Dis 2004 27: 305-318.

Desjeux P., Alvar J. (2003) Leishmania/HIV co-infections: epidemiology in Europe. Ann Trop Med Parasitol 97 Suppl 1: 3-15.

Díaz González R., Pérez Pertejo Y., Ordóñez D., Balaña-Fouce R., Reguera RM. (2007) Deletion study of DNA topoisomerase IB from Leishmania donovani: searching for a minimal functional heterodimer. PLoS One 2: e1177.

Díaz-González R., Pérez-Pertejo Y., Pommier Y., Balaña-Fouce R., Reguera RM. (2008) Mutational study of the "catalytic tetrad" of DNA topoisomerase IB from the hemoflagellate Leishmania donovani: Role of Asp-353 and Asn-221 in camptothecin resistance. Biochem Pharmacol 76: 608-619.

Dietze R., Carvalho SF., Valli LC., Berman J., Brewer T., Milhous W., Sanchez J., Schuster B., Grogl M. (2001) Phase 2 trial of WR6026, an orally administered 8aminoquinoline, in the treatment of visceral leishmaniasis caused by Leishmania chagasi. Am J Trop Med Hyg 65: 685-689.

Dillon RJ., Lane RP. (1993) Influence of Leishmania infection on blood-meal digestion in the sandflies Phlebotomus papatasi and P. langeroni. Parasitol Res 79: 492-496. 
Doherty TM., Coffman RL. (1996) Leishmania major: effect of infectious dose on T cell subset development in BALB/c mice. Exp Parasitol 84: 124-135.

Donnelly JJ., Ulmer JB., Shiver JW., Liu MA. (1997) DNA vaccines. Annu Rev Immunol 15: 617-648.

Donovan C. (1903) The etiology of the heterogeneous fevers in India. Br Med J 2: 1401.

Dorlo TP., van Thiel PP., Huitema AD., Keizer RJ., de Vries HJ., Beijnen JH., de Vries PJ. (2008) Pharmacokinetics of miltefosine in Old World cutaneous leishmaniasis patients. Antimicrob Agents Chemother 52: 2855-2860.

Dostalova A., Volf P. (2012) Leishmania development in sand flies: parasite-vector interactions overview. Parasit Vectors 5: 276.

Dostalova A., Votýpka J., Favreau AJ., Barbian KD., Volf P., Valenzuela JG., Jochim RC. (2011) The midgut transcriptome of Phlebotomus (Larroussius) perniciosus, a vector of Leishmania infantum: comparison of sugar fed and blood fed sand flies. BMC Genomics 12: 223.

Dube A., Gupta R., Singh N. (2009) Reporter genes facilitating discovery of drugs targeting protozoan parasites. Trends Parasitol 25: 432-439.

Dujardin JC., Dujardin JP., Tibayrenc M., Timperman G., De Doncker S., Jacquet D., Arevalo J., Llanos-Cuentas A., Guerra H., Bermudez H. (1995) Karyotype plasticity in neotropical Leishmania: an index for measuring genomic distance among $L$. (V.) peruviana and L. (V.) braziliensis populations. Parasitology 110: 21-30.

Escomel E. (1929) La leishmaniose amèricaine et les leishmanioses en amèriques. Bull Soc Path Exot 22: 35-46.

Evans DA., Kennedy WP., Elbihari S., Chapman CJ., Smith V., Peters W. (1987) Hybrid formation within the genus Leishmania? Parassitologia 29: 165-173.

Ezra N., Ochoa MT., Craft N. (2010) Human immunodeficiency virus and leishmaniasis. J Glob Infect Dis 2: 248-257.

Faria MS., Reis FC., Lima AP. (2012) Toll-like receptors in Leishmania infections: guardians or promoters? J Parasitol Res 2012: 930257.

Feldhaar H., Gross R. (2008) Insects as hosts for mutualistic bacteria. Int J Med Microbiol 299: 1-8.

Filonov GS., Piatkevich KD., Ting LM., Zhang J., Kim K., Verkhusha VV. (2011) Bright and stable near-infrared fluorescent protein for in vivo imaging. Nat Biotechnol 29: 757-761.

Fischer AJ., Lagarias JC. (2004) Harnessing phytochrome's glowing potential. Proc Natl Acad Sci USA 101: 17334-17339.

Flandin JF., Chano F., Descoteaux A. (2006) RNA interference reveals a role for TLR2 and TLR3 in the recognition of Leishmania donovani promastigotes by interferon-gamma-primed macrophages. Eur J Immunol 36: 411-420. 
Foglia Manzillo V., Di Muccio T., Cappiello S., Scalone A., Paparcone R., Fiorentino E., Gizzarelli M., Gramiccia M., Gradoni L., Oliva G. (2013) Prospective study on the incidence and progression of clinical signs in naïve dogs naturally infected by Leishmania infantum. PLoS Negl Trop Dis 7: e2225.

Folgueira C., Quijada L., Soto M., Abanades DR., Alonso C., Requena JM. (2005) The translational efficiencies of the two Leishmania infantum HSP70 mRNAs, differing in their 3'-untranslated regions, are affected by shifts in the temperature of growth through different mechanisms. J Biol Chem 280: 35172-35183.

Forestier CL., Machu C., Loussert C., Pescher P., Späth GF. (2011) Imaging host cellLeishmania interaction dynamics implicates parasite motility, lysosome recruitment, and host cell wounding in the infection process. Cell Host Microbe 9: 319-330.

Fraga J., Montalvo AM., De Doncker S., Dujardin JC., Van der Auwera G. (2010) Phylogeny of Leishmania species based on the heat-shock protein 70 gene. Infect Genet Evol 10: 238-245.

Franco LH., Beverley SM., Zamboni DS. (2012) Innate immune activation and subversion of Mammalian functions by Leishmania lipophosphoglycan. J Parasitol Res 2012: 165126.

Franke-Fayard B., Waters AP., Janse CJ. (2006) Real-time in vivo imaging of transgenic bioluminescent blood stages of rodent malaria parasites in mice. Nat Protoc 1: 476-485.

Freitas-Junior LH., Chatelain E., Kim HA., Siqueira-Neto JL. (2012) Visceral leishmaniasis treatment: What do we have, what do we need and how to deliver it? Int J Parasitol Drugs Drug Resist 2: 11-19.

Garg R., Trudel N., Tremblay MJ. (2007) Consequences of the natural propensity of Leishmania and HIV-1 to target dendritic cells. Trends Parasitol 23: 317-324.

Gaunt MW., Yeo M., Frame IA., Stothard JR., Carrasco HJ., Taylor MC., Mena SS., Veazey P., Miles GA., Acosta N., de Arias AR., Miles MA. (2003) Mechanism of genetic exchange in American trypanosomes. Nature 421: 936-939.

Gautam S., Kumar R., Maurya R., Nylén S., Ansari N., Rai M., Sundar S., Sacks DL. (2011) IL-10 neutralization promotes parasite clearance in splenic aspirate cells from patients with visceral leishmaniasis. J Infect Dis 204: 1134-1137.

Gibson ME. (1983) The identification of kala-azar and the discovery of Leishmania donovani. Med Hist 27: 203-123.

Gibson W., Garside L., Bailey M. (1992) Trisomy and chromosome size changes in hybrid trypanosomes from a genetic cross between Trypanosoma brucei rhodesiense and T. b. brucei. Mol Biochem Parasitol 51: 189-199.

Gibson W., Peacock L., Ferris V., Williams K., Bailey M. (2008) The use of yellow fluorescent hybrids to indicate mating in Trypanosoma brucei. Parasit Vectors 1: 4. 
Gibson WC., Osinga KA., Michels PA., Borst P. (1985) Trypanosomes of subgenus Trypanozoon are diploid for housekeeping genes. Mol Biochem Parasitol 16: 231242.

Gicheru MM., Olobo JO., Kariuki TM., Adhiambo C. (1995) Visceral leishmaniasis in ververt monkeys: immunological responses during asymptomatic infections. Scand J Immunol 41: 202-208.

Gil-Prieto R., Walter S., Alvar J., de Miguel AG. (2011) Epidemiology of leishmaniasis in Spain based on hospitalization records (1997-2008). Am J Trop Med Hyg 85: 820-825.

Gillespie M., Titus RG. (2000) The immunomodulatory factors of bloodfeeding arthropod saliva. Parasite Immunol 22: 319-331.

Goodwin LG. (1995) Pentostam (sodium stibogluconate); a 50-year personal reminiscence. Trans R Soc Trop Med Hyg 89: 339-341.

Goto H., Prianti MG. (2009) Immunoactivation and immunopathogeny during active visceral leishmaniasis. Rev Inst Med Trop Sao Paulo 51: 241-246.

Greene WC. (2007) A history of AIDS: looking back to see ahead. Eur J Immunol 37 Suppl 1: S94-102.

Griesbeck O., Baird GS., Campbell RE., Zacharias DA., Tsien RY. (2001) Reducing the environmental sensitivity of yellow fluorescent protein. Mechanism and applications. J Biol Chem 276: 29188-29194.

Grimaldi Jr G. (2008) The utility of rhesus monkey (Macaca mulatta) and nonhuman primate models for preclinical testing of Leishmania candidate vaccines. Mem Inst Oswaldo Cruz 103: 629-644.

Gueiros-Filho FJ., Beverley SM. (1996) Selection against the dihydrofolate reductase-thymidylate synthase (DHFR-TS) locus as a probe of genetic alterations in Leishmania major. Mol Cell Biol 16: 5655-5663.

Guha R., Gupta D., Rastogi R., Vikram R., Krishnamurthy G., Bimal S., Roy S., Mukhopadhyay A. (2013) Vaccination with Leishmania hemoglobin receptorencoding DNA protects against visceral leishmaniasis. Sci Transl Med 5: 202ra121.

Guha-Niyogi A., Sullivan DR., Turco SJ. (2001) Glycoconjugate structures of parasitic protozoa. Glycobiology 11: 45R-59R.

Gupta G., Oghumu S., Satoskar AR. (2013) Mechanisms of immune evasion in leishmaniasis. Adv Appl Microbiol 82: 155-184.

Gupta S., Nishi. (2011) Visceral leishmaniasis: experimental models for drug discovery. Indian J Med Res 133: 27-39.

Ha DS., Schwarz JK., Turco SJ., Beverley SM. (1996) Use of the green fluorescent protein as a marker in transfected Leishmania. Mol Biochem Parasitol 77: 57-64.

Haldar AK., Sen P., Roy S. (2011) Use of antimony in the treatment of leishmaniasis: current status and future directions. Mol Biol Int 2011: 571242. 
Handman E. (1999) Cell biology of Leishmania. Adv Parasitol 44: 1-39.

Handman E. (2001) Leishmaniasis: current status of vaccine development. Clin Microbiol Rev 14: 229-243.

Hao Z., Kasumba I., Lehane MJ., Gibson WC., Kwon J., Aksoy S. (2001) Tsetse immune responses and trypanosome transmission: implications for the development of tsetse-based strategies to reduce trypanosomiasis. Proc Natl Acad Sci USA 98: 12648-12653.

Hartl DL. (1992) Population genetics of microbial organisms. Curr Opin Genet Dev 2: 937-942.

Hashim FA., Khalil EA., Ismail A., el Hassan AM. (1995) Apparently successful treatment of two cases of post kala-azar dermal leishmaniasis with liposomal amphotericin B. Trans R Soc Trop Med Hyg 89: 440.

Hayden EC. (2014) Projects set to tackle neglected diseases. Nature 505: 142.

Hazra S., Ghosh S., Das Sarma M., Sharma S., Das M., Saudagar P., Prajapati VK., Dubey VK., Sundar S., Hazra B. (2013) Evaluation of a diospyrin derivative as antileishmanial agent and potential modulator of ornithine decarboxylase of Leishmania donovani. Exp Parasitol 135: 407-413.

Heim R., Cubitt AB., Tsien RY. (1995) Improved green fluorescence. Nature 373: 663-664.

Heim R., Prasher DC., Tsien RY. (1994) Wavelength mutations and posttranslational autoxidation of green fluorescent protein. Proc Natl Acad Sci USA 91: 12501-12504.

Heim R., Tsien RY. (1996) Engineering green fluorescent protein for improved brightness, longer wavelengths and fluorescence resonance energy transfer. Curr Biol 6: 178-182.

Heisig P. (2001) Inhibitors of bacterial topoisomerases: mechanisms of action and resistance and clinical aspects. Planta Med 67: 3-12.

Hermoso T., Fishelson Z., Becker SI., Hirschberg K., Jaffe CL. (1991) Leishmanial protein kinases phosphorylate components of the complement system. EMBO J 10: 4061-4067.

Hertzberg RP., Caranfa MJ., Hecht SM. (1989) On the mechanism of topoisomerase I inhibition by camptothecin: evidence for binding to an enzyme-DNA complex. Biochemistry 28: 4629-4638.

Heussler V., Doerig C. (2006) In vivo imaging enters parasitology. Trends Parasitol 22: 192-195.

Hoare CA. (1938) Early discoveries regarding parasite of oriental sore. Trans Roy Soc Trop Med Hyg 32: 67-92.

Holm A., Tejle K., Magnusson KE., Descoteaux A., Rasmusson B. (2001) Leishmania donovani lipophosphoglycan causes periphagosomal actin accumulation: 
correlation with impaired translocation of PKCalpha and defective phagosome maturation. Cell Microbiol 3: 439-447.

Holzer TR., McMaster WR., Forney JD. (2006) Expression profiling by wholegenome interspecies microarray hybridization reveals differential gene expression in procyclic promastigotes, lesion-derived amastigotes, and axenic amastigotes in Leishmania mexicana. Mol Biochem Parasitol 146: 198-218.

Hope M., MacLeod A., Leech V., Melville S., Sasse J., Tait A., Turner CM. (1999) Analysis of ploidy (in megabase chromosomes) in Trypanosoma brucei after genetic exchange. Mol Biochem Parasitol 104: 1-9.

Hsiao CH., Ueno N., Shao JQ., Schroeder KR., Moore KC., Donelson JE., Wilson ME. (2011) The effects of macrophage source on the mechanism of phagocytosis and intracellular survival of Leishmania. Microbes Infect 13: 1033-1044.

Huber M., Timms E., Mak TW., Röllinghoff M., Lohoff M. (1998) Effective and longlasting immunity against the parasite Leishmania major in CD8-deficient mice. Infect Immun 66: 3968-3970.

Ibrahim AS., Magee BB., Sheppard DC., Yang M., Kauffman S., Becker J., Edwards JE. Jr, Magee PT. (2005) Effects of ploidy and mating type on virulence of Candida albicans. Infect Immun 73: 7366-7374.

Inbar E., Akopyants NS., Charmoy M., Romano A., Lawyer P., Elnaiem DE., Kauffmann F., Barhoumi M., Grigg M., Owens K., Fay M., Dobson DE., Shaik J., Beverley SM., Sacks D. (2013) The mating competence of geographically diverse Leishmania major strains in their natural and unnatural sand fly vectors. PLoS Genet 9: e1003672.

Iniesta V., Gómez-Nieto LC., Molano I., Mohedano A., Carcelén J., Mirón C., Alonso C., Corraliza I. (2002) Arginase I induction in macrophages, triggered by Th2-type cytokines, supports the growth of intracellular Leishmania parasites. Parasite Immunol 24: 113-118.

Inoue Y., Izawa K., Kiryu S., Tojo A., Ohtomo K. (2008) Diet and abdominal autofluorescence detected by in vivo fluorescence imaging of living mice. Mol Imaging 7: 21-27.

Iovannisci DM., Beverley SM. (1989) Structural alterations of chromosome 2 in Leishmania major as evidence for diploidy, including spontaneous amplification of the mini-exon array. Mol Biochem Parasitol 34: 177-188.

Jain SK., Sahu R., Walker LA., Tekwani BL. (2012) A parasite rescue and transformation assay for antileishmanial screening against intracellular Leishmania donovani amastigotes in THP1 human acute monocytic leukemia cell line. J Vis Exp pii: 4054.

Jenni L., Marti S., Schweizer J., Betschart B., Le Page RW., Wells JM., Tait A., Paindavoine P., Pays E., Steinert M. (1986) Hybrid formation between African trypanosomes during cyclical transmission. Nature 322: 173-175. 
Jones DE., Buxbaum LU., Scott P. (2000) IL-4-independent inhibition of IL-12 responsiveness during Leishmania amazonensis infection. J Immunol 165: 364-372.

Joshi A., Narain JP., Prasittisuk C., Bhatia R., Hashim G., Jorge A., Banjara M., Kroeger A. (2008) Can visceral leishmaniasis be eliminated from Asia? J Vector Borne Dis 45: 105-111.

Kamhawi S. (2006) Phlebotomine sand flies and Leishmania parasites: friends or foes? Trends Parasitol 22: 439-445.

Kamir D., Zierow S., Leng L., Cho Y., Diaz Y., Griffith J., McDonald C., Merk M., Mitchell RA., Trent J., Chen Y., Kwong YK., Xiong H., Vermeire J., Cappello M., McMahon-Pratt D., Walker J., Bernhagen J., Lolis E., Bucala R. (2008) A Leishmania ortholog of macrophage migration inhibitory factor modulates host macrophage responses. J Immunol 180: 8250-8261.

Kandpal M., Tekwani BL. (1997) Polyamine transport systems of Leishmania donovani promastigotes. Life Sci 60: 1793-1801.

Katzman SD., Fowell DJ. (2008) Pathogen-imposed skewing of mouse chemokine and cytokine expression at the infected tissue site. J Clin Invest 118: 801-811.

Kavoosi G., Ardestani SK., Kariminia A. (2009) The involvement of TLR2 in cytokine and reactive oxygen species (ROS) production by PBMCs in response to Leishmania major phosphoglycans (PGs). Parasitology 136: 1193-1199.

Kavoosi G., Ardestani SK., Kariminia A., Alimohammadian MH. (2010) Leishmania major lipophosphoglycan: discrepancy in Toll-like receptor signaling. Exp Parasitol 124: 214-218.

Kaye P., Scott P. (2011) Leishmaniasis: complexity at the host-pathogen interface. Nat Rev Microbiol 9: 604-615.

Kazemi B. (2011) Genomic organization of Leishmania species. Iran J Parasitol 6: 118.

Kedzierska K., Crowe SM. (2002) The role of monocytes and macrophages in the pathogenesis of HIV-1 infection. Curr Med Chem 9: 1893-1903.

Kelly JM., Law JM., Chapman CJ., Van Eys GJ., Evans DA. (1991) Evidence of genetic recombination in Leishmania. Mol Biochem Parasitol 46: 253-263.

Kenney RT., Sacks DL., Sypek JP., Vilela L., Gam AA., Evans-Davis K. (1999) Protective immunity using recombinant human IL-12 and alum as adjuvants in a primate model of cutaneous leishmaniasis. J Immunol 163: 4481-4488.

Khamesipour A., Dowlati Y., Asilian A., Hashemi-Fesharki R., Javadi A., Noazin S., Modabber F. (2005) Leishmanization: use of an old method for evaluation of candidate vaccines against leishmaniasis. Vaccine 23: 3642-3648.

Khan W., Kumar R., Singh S., Arora SK., Kumar N. (2013) Paromomycin-loaded albumin microspheres: efficacy and stability studies. Drug Test Anal 5: 468-473. 
Killick-Kendrick R. (1999) The biology and control of phlebotomine sand flies. Clin Dermatol 17: 279-289.

Kimblin N., Peters N., Debrabant A., Secundino N., Egen J., Lawyer P., Fay MP., Kamhawi S., Sacks D. (2008) Quantification of the infectious dose of Leishmania major transmitted to the skin by single sand flies. Proc Natl Acad Sci USA 105: 10125-10130.

Klowden MJ., Lea AO. (1978) Blood meal size as a factor affecting continued hostseeking by Aedes aegypti (L.). Am J Trop Med Hyg 27: 827-831.

Koutinas AF., Saridomichelakis MN., Mylonakis ME., Leontides L., Polizopoulou Z., Billinis C., Argyriadis D., Diakou N., Papadopoulos O. (2001) A randomised, blinded, placebo-controlled clinical trial with allopurinol in canine leishmaniosis. Vet Parasitol 98: 247-261.

Kram D., Thäle C., Kolodziej H., Kiderlen AF. (2008) Intracellular parasite kill: flow cytometry and NO detection for rapid discrimination between anti-leishmanial activity and macrophage activation. J Immunol Methods 333: 79-88.

Krauss K., James JS. (2003) Federal AIDS policy emergencies. AIDS Treat News 392: 3-5.

Kreutzer RD., Yemma JJ., Grogl M., Tesh RB., Martin TI. (1994) Evidence of sexual reproduction in the protozoan parasite Leishmania (Kinetoplastida: Trypanosomatidae). Am J Trop Med Hyg 51: 301-307.

Kumar R., Engwerda C. (2014) Vaccines to prevent leishmaniasis. Clin Trans Immunol 3: e13.

Kumar R., Nylén S. (2012) Immunobiology of visceral leishmaniasis. Front Immunol 3: 251.

Lachaud L., Bourgeois N., Kuk N., Morelle C., Crobu L., Merlin G., Bastien P., Pagès M., Sterkers Y. (2014) Constitutive mosaic aneuploidy is a unique genetic feature widespread in the Leishmania genus. Microbes Infect 16: 61-66.

Laguna F., López-Vélez R., Pulido F., Salas A., Torre-Cisneros J., Torres E., Medrano FJ., Sanz J., Picó G., Gómez-Rodrigo J., Pasquau J., Alvar J. (1999) Treatment of visceral leishmaniasis in HIV-infected patients: a randomized trial comparing meglumine antimoniate with amphotericin B. Spanish HIV-Leishmania Study Group. AIDS 13: 1063-1069.

Laguna F., Videla S., Jiménez-Mejías ME., Sirera G., Torre-Cisneros J., Ribera E., Prados D., Clotet B., Sust M., López-Vélez R., Alvar J; Spanish HIV-Leishmania Study Group. (2003) Amphotericin B lipid complex versus meglumine antimoniate in the treatment of visceral leishmaniasis in patients infected with HIV: a randomized pilot study. J Antimicrob Chemother 52: 464-468.

Lang T., Courret N., Colle JH., Milon G., Antoine JC. (2003) The levels and patterns of cytokines produced by CD4 T lymphocytes of BALB/c mice infected with Leishmania major by inoculation into the ear dermis depend on the infectiousness and size of the inoculum. Infect Immun 71: 2674-2683. 
Lang T., Goyard S., Lebastard M., Milon G. (2005) Bioluminescent Leishmania expressing luciferase for rapid and high throughput screening of drugs acting on amastigote-harbouring macrophages and for quantitative real-time monitoring of parasitism features in living mice. Cell Microbiol 7: 383-392.

Lang T., Lecoeur H, Prina E. (2009) Imaging Leishmania development in their host cells. Trends Parasitol 25: 464-473.

Latorre-Esteves E., Akilov OE., Rai P., Beverley SM., Hasan T. (2010) Monitoring the efficacy of antimicrobial photodynamic therapy in a murine model of cutaneous leishmaniasis using L. major expressing GFP. J Biophotonics 3: 328-335.

Lecoeur H., Buffet P., Morizot G., Goyard S., Guigon G., Milon G., Lang T. (2007) Optimization of topical therapy for Leishmania major localized cutaneous leishmaniasis using a reliable C57BL/6 model. PLoS Negl Trop Dis 1: e34.

Lecoeur H., Buffet PA., Milon G., Lang T. (2010) Early curative applications of the aminoglycoside WR279396 on an experimental Leishmania major-loaded cutaneous site do not impair the acquisition of immunity. Antimicrob Agents Chemother 54: 984-990.

Lecoq J., Schnitzer MJ. (2011) An infrared fluorescent protein for deeper imaging. Nat Biotechnol 29: 715-716.

Liang PH., Anderson KS. (1998) Kinetic reaction scheme for the dihydrofolate reductase domain of the bifunctional thymidylate synthase-dihydrofolate reductase from Leishmania major. Biochemistry 37: 12206-12212.

Lima HC., Titus RG. (1996) Effects of sand fly vector saliva on development of cutaneous lesions and the immune response to Leishmania braziliensis in BALB/c mice. Infect Immun 64: 5442-5445.

Lin MZ., McKeown MR., Ng HL., Aguilera TA., Shaner NC., Campbell RE., Adams SR., Gross LA., Ma W., Alber T., Tsien RY. (2009) Autofluorescent proteins with excitation in the optical window for intravital imaging in mammals. Chem Biol 16: 1169-1179.

Lo SK., Bovis L., Matura R., Zhu B., He S., Lum H., Turco SJ., Ho JL. (1998) Leishmania lipophosphoglycan reduces monocyte transendothelial migration: modulation of cell adhesion molecules, intercellular junctional proteins, and chemoattractants. J Immunol 160: 1857-1865.

Locksley RM., Reiner SL., Hatam F., Littman DR., Killeen N. (1993) Helper T cells without CD4: control of leishmaniasis in CD4-deficient mice. Science 261: 14481451.

Luque-Ortega JR., Rivero-Lezcano OM., Croft SL., Rivas L. (2001) In vivo monitoring of intracellular ATP levels in Leishmania donovani promastigotes as a rapid method to screen drugs targeting bioenergetic metabolism. Antimicrob Agents Chemother 45: 1121-1125.

MacLeod A., Tweedie A., McLellan S., Hope M., Taylor S., Cooper A., Sweeney L., Turner CM., Tait A. (2005) Allelic segregation and independent assortment in $T$. 
brucei crosses: proof that the genetic system is Mendelian and involves meiosis. Mol Biochem Parasitol 143: 12-19.

Maltezou HC. (2010) Drug resistance in visceral leishmaniasis. J Biomed Biotechnol 2010: 617521.

Mastroianni A. (2004) Liposomal amphotericin B and rHuGM-CSF for treatment of visceral leishmaniasis in AIDS. Infez Med 12: 197-204.

Matz MV., Fradkov AF., Labas YA., Savitsky AP., Zaraisky AG., Markelov ML., Lukyanov SA. (1999) Fluorescent proteins from nonbioluminescent Anthozoa species. Nat Biotechnol 17: 969-973.

McLatchie AP., Burrell-Saward H., Myburgh E., Lewis MD., Ward TH., Mottram JC., Croft SL., Kelly JM., Taylor MC. (2013) Highly sensitive in vivo imaging of Trypanosoma brucei expressing "red-shifted" luciferase. PLoS Negl Trop Dis 7: e2571.

McMahon-Pratt D., Alexander J. (2004) Does the Leishmania major paradigm of pathogenesis and protection hold for New World cutaneos leishmaniases or the visceral disease? Immunol Rev 201: 206-224.

Mehta SR., Huang R., Yang M., Zhang XQ., Kolli B., Chang KP., Hoffman RM., Goto Y., Badaro R., Schooley RT. (2008) Real-time in vivo green fluorescent protein imaging of a murine leishmaniasis model as a new tool for Leishmania vaccine and drug discovery. Clin Vaccine Immunol 15: 1764-1770.

Melby P., Tryon V., Chandrasekar V., Freeman GL. (1998) Cloning of Syrian hamster (Mesocricetus auratus) cytokine cDNAs and analysis of cytokine mRNA expression in experimental visceral leishmaniasis. Infect Immun 66: 2135-2142.

Melby PC., Chandrasekar B., Zhao W., Coe JE. (2001) The hamster as a model of human visceral leishmaniasis: progressive disease and impaired generation of nitric oxide in the face of a prominent Th1-like cytokine response. J Immunol 166: 1912-1920.

Menezes-Sousa D., Corrêa-Oliveira R., Guerra-Sá R., Giunchetti RC., TexeiraCarvalho A., Martins-Filho OA., Oliveira GC., Reis AB. (2011) Cytokine and transcription factor profiles in the skin of dogs naturally infected by Leishmania (Leishmania) chagasi presenting distinct cutaneous parasite density and clinical status. Vet Parasitol 177: 39-49.

Michel G., Ferrua B., Lang T., Maddugoda MP., Munro P., Pomares C., Lemichez E., Marty P. (2011) Luciferase-expressing Leishmania infantum allows the monitoring of amastigote population size, in vivo, ex vivo and in vitro. PLoS Negl Trop Dis 5: e1323.

Miles MA., Yeo M., Mauricio IL. (2009) Genetics. Leishmania exploit sex. Science 324: 187-189.

Millington OR., Myburgh E., Mottram JC., Alexander J. (2010) Imaging of the host/parasite interplay in cutaneous leishmaniasis. Exp Parasitol 126: 310-317. 
Mishra M., Biswas UK., Jha DN., Khan AB. (1992) Amphotericin versus pentamidine in antimony-unresponsive kala-azar. Lancet 340: 1256-1257.

Mißlitz A., Mottram JC., Overath P., Aebischer T. (2000) Targeted integration into a rRNA locus results in uniform and high level expression of transgenes in Leishmania amastigotes. Mol Biochem Parasitol 107: 251-261.

Mohapatra S. (2014) Drug resistance in leishmaniasis: Newer developments. Trop Parasitol 4: 4-9.

Monge-Maillo B., López-Vélez R. (2013) Therapeutic options for visceral leishmaniasis. Drugs 73: 1863-1888.

Mookerjee A., Sen PC., Ghose AC. (2003) Immunosuppression in hamsters with progressive visceral leishmaniasis is associated with an impairment of protein kinase $\mathrm{C}$ activity in their lymphocytes that can be partially reversed by okadaic acid or anti-transforming growth factor $\beta$ antibody. Infect Immun 71: 2439-2446.

Morise H., Shimomura O., Johnson FH., Winant J. (1974) Intermolecular energy transfer in the bioluminescent system of Aequorea. Biochemistry 13: 2656-2662.

Mottram JC., Coombs GH. (1998) Leishmania cysteine proteinases: virulence factors in quest of a function-reply. Parasitol Today 14: 251-252.

Murray HW., Delph-Etienne S. (2000) Roles of endogenous gamma interferon and macrophage microbicidal mechanisms in host response to chemotherapy in experimental visceral leishmaniasis. Infect Immun 68: 288-293.

Murray HW., Masur H., Keithly JS. (1982) Cell mediated immune response in experimental visceral leishmaniasis. I. Correlation between resistance to $L$. donovani and lymphokine-generating capacity. J Immunol 129: 344-350.

Musa A., Khalil E., Hailu A., Olobo J., Balasegaram M., Omollo R., Edwards T., Rashid J., Mbui J., Musa B., Abuzaid AA., Ahmed O., Fadlalla A., El-Hassan A., Mueller M., Mucee G., Njoroge S., Manduku V., Mutuma G., Apadet L., Lodenyo H., Mutea D., Kirigi G., Yifru S., Mengistu G., Hurissa Z., Hailu W., Weldegebreal T., Tafes H., Mekonnen Y., Makonnen E., Ndegwa S., Sagaki P., Kimutai R., Kesusu J., Owiti R., Ellis S., Wasunna M. (2012) Sodium stibogluconate (SSG) \& paromomycin combination compared to SSG for visceral leishmaniasis in East Africa: a randomised controlled trial. PLoS Negl Trop Dis 6: e1674.

Myburgh E., Coles JA., Ritchie R., Kennedy PG., McLatchie AP., Rodgers J., Taylor MC., Barrett MP., Brewer JM., Mottram JC. (2013) In vivo imaging of trypanosome-brain interactions and development of a rapid screening test for drugs against CNS stage trypanosomiasis. PLoS Negl Trop Dis 7: e2384.

Nadim A., Javadian E., Tahvildar-Bidruni G., Ghorbani M. (1983) Effectiveness of leishmanization in the control of cutaneous leishmaniasis. Bull Soc Pathol Exot Filiales 76: 377-383.

Nascimento E., Fernandes DF., Vieira EP., Campos-Neto A., Ashman JA., Alves FP., Coler RN., Bogatzki LY., Kahn SJ., Beckmann AM., Pine SO., Cowgill KD., Reed SG., Piazza FM. (2010) A clinical trial to evaluate the safety and immunogenicity of the 
LEISH-F1+MPL-SE vaccine when used in combination with meglumine antimoniate for the treatment of cutaneous leishmaniasis. Vaccine 28: 6581-6587.

Navin TR., Arana BA., Arana FE., Berman JD., Chajón JF. (1992) Placebo-controlled clinical trial of sodium stibogluconate (Pentostam) versus ketoconazole for treating cutaneous leishmaniasis in Guatemala. J Infect Dis 165: 528-534.

Nolder D., Roncal N., Davies CR., Llanos-Cuentas A., Miles MA. (2007) Multiple hybrid genotypes of Leishmania (Viannia) in a focus of mucocutaneous Leishmaniasis. Am J Trop Med Hyg 76: 573-578.

Olivier M., Gregory DJ., Forget G. (2005) Subversion mechanisms by which Leishmania parasites can escape the host immune response: a signaling point of view. Clin Microbiol Rev 18: 293-305.

Omollo R., Alexander N., Edwards T., Khalil EA., Younis BM., Abuzaid AA., Wasunna M., Njoroge N., Kinoti D., Kirigi G., Dorlo TP., Ellis S., Balasegaram M., Musa AM. (2011) Safety and efficacy of miltefosine alone and in combination with sodium stibogluconate and liposomal amphotericin B for the treatment of primary visceral leishmaniasis in East Africa: study protocol for a randomized controlled trial. Trials 12: 166.

OMS. (2010) Control of the leishmaniases. Report of a WHO expert committee. World Health Organ Tech Rep Ser 949: 1-186.

Ormö M., Cubitt AB., Kallio K., Gross LA., Tsien RY., Remington SJ. (1996) Crystal structure of the Aequorea victoria green fluorescent protein. Science 273: 13921395.

Osorio Y., Travi BL., Renslo AR., Peniche AG., Melby PC. (2011) Identification of small molecule lead compounds for visceral leishmaniasis using a novel ex vivo splenic explant model system. PLoS Negl Trop Dis 5: e962.

Oura M., Sternberg TH., Wright ET. (1955) A new antifungal antibiotic, amphotericin B. Antibiot Annu 3: 566-573.

Paloque L., Vidal N., Casanova M., Dumètre A., Verhaeghe P., Parzy D., Azas N. (2013) A new, rapid and sensitive bioluminescence assay for drug screening on Leishmania. J Microbiol Methods 95: 320-323.

Pandey K., Pun SB., Pandey BD. (2012) Relapse of kala-azar after use of multiple drugs: a case report and brief review of literature. Indian J Med Microbiol 30: 227229.

Papadopoulou B., Roy G., Breton M., Kündig C., Dumas C., Fillion I., Singh AK., Olivier M., Ouellette M. (2002) Reduced infectivity of a Leishmania donovani biopterin transporter genetic mutant and its use as an attenuated strain for vaccination. Infect Immun 70: 62-68.

Paredes R., Munoz J., Diaz I., Domingo P., Gurgui M., Clotet B. (2003) Leishmaniasis in HIV infection. J Postgrad Med 49: 39-49. 
Payne DJ., Gwynn MN., Holmes DJ., Pompliano DL. (2007) Drugs for bad bugs: confronting the challenges of antibacterial discovery. Nat Rev Drug Discov 6: 29-40.

Peacock L., Bailey M., Carrington M., Gibson W. (2014) Meiosis and haploid gametes in the pathogen Trypanosoma brucei. Curr Biol 24: 181-186.

Peacock L., Ferris V., Bailey M., Gibson W. (2009) Intraclonal mating occurs during tsetse transmission of Trypanosoma brucei. Parasit Vectors 2: 43.

Peacock L., Ferris V., Bailey M., Gibson W. (2014) Mating compatibility in the parasitic protist Trypanosoma brucei. Parasit Vectors 7: 78.

Peacock L., Ferris V., Sharma R., Sunter J., Bailey M., Carrington M., Gibson W. (2011) Identification of the meiotic life cycle stage of Trypanosoma brucei in the tsetse fly. Proc Natl Acad Sci USA 108: 3671-3676.

Peniche AG., Osorio Y., Renslo AR., Frantz DE., Melby PC., Travi BL. (2014) Development of an ex vivo lymph node explant model for identification of novel molecules active against Leishmania major. Antimicrob Agents Chemother 58: 7887.

Perez LE., Chandrasekar B., Saldarriaga OA., Zhao W., Arteaga LT., Travi BL., Melby PC. (2006) Reduced nitric oxide synthase 2 (NOS2) promoter activity in the Syrian hamster renders the animal functionally deficient in NOS2 activity and unable to control an intracellular pathogen. J Immunol 176: 5519-5528.

Pescher P., Blisnick T., Bastin P., Späth GF. (2011) Quantitative proteome profiling informs on phenotypic traits that adapt Leishmania donovani for axenic and intracellular proliferation. Cell Microbiol 13: 978-991.

Peters N., Sacks D. (2006) Immune privilege in sites of chronic infection: Leishmania and regulatory T cells. Immunol Rev 213: 159-79.

Pimenta PF., Modi GB., Pereira ST., Shahabuddin M., Sacks DL. (1997) A novel role for the peritrophic matrix in protecting Leishmania from the hydrolytic activities of the sand fly midgut. Parasitology 115: 359-369.

Pinelli E., Gonzalo RM., Boog CJP., Rutten V., Gebhard D., Del Real G., Ruitenberg EJ. (1995) Leishmania infantum specific $T$ cell lines derived from asymptomatic dogs that lyse infected macrophages in a major histocompatibility complex restricted manner. Eur J Immunol 25: 1594-600.

Pinheiro NF., Hermida MD., Macedo MP., Mengel J., Bafica A., dos-Santos WL. (2006) Leishmania infection impairs beta 1-integrin function and chemokine receptor expression in mononuclear phagocytes. Infect Immun 74: 3912-3921.

Plock A., Sokolowska-Köhler W., Presber W. (2001) Application of flow cytometry and microscopical methods to characterize the effect of herbal drugs on Leishmania spp. Exp Parasitol 97: 141-153.

Pommier Y. (2006) Topoisomerase I inhibitors: camptothecins and beyond. Nat Rev Cancer 6: 789-802. 
Porrozzi R., Teva A., Amaral VF., Santos da Costa MV., Grimaldi G Jr. (2004) Crossimmunity experiments between different species or strains of Leishmania in Rhesus macaques (Macaca mulatta). Am J Trop Med Hyg 71: 297-305.

Prada CF., Álvarez-Velilla R., Balaña-Fouce R., Prieto C., Calvo-Álvarez E., EscuderoMartínez JM., Requena JM., Ordóñez C., Desideri A., Pérez-Pertejo Y., Reguera RM. (2013) Gimatecan and other camptothecin derivatives poison leishmania DNAtopoisomerase IB leading to a strong leishmanicidal effect. Biochem Pharmacol 85: 1433-1440.

Prasher DC., Eckenrode VK., Ward WW., Prendergast FG., Cormier MJ. (1992) Primary structure of the Aequorea victoria green-fluorescent protein. Gene 111: 229-233.

Prudhomme M. (2003) Rebeccamycin analogues as anti-cancer agents. Eur J Med Chem 38: 123-140.

Puentes SM., Da Silva RP., Sacks DL., Hammer CH., Joiner KA. (1990) Serum resistance of metacyclic stage Leishmania major promastigotes is due to release of C5b-9. J Immunol 145: 4311-4316.

Pulido SA., Muñoz DL., Restrepo AM., Mesa CV., Alzate JF., Vélez ID., Robledo SM. (2012) Improvement of the green fluorescent protein reporter system in Leishmania spp. for the in vitro and in vivo screening of antileishmanial drugs. Acta Trop 122: 36-45.

Purkait B., Kumar A., Nandi N., Sardar AH., Das S., Kumar S., Pandey K., Ravidas V., Kumar M., De T., Singh D., Das P. (2012) Mechanism of amphotericin B resistance in clinical isolates of Leishmania donovani. Antimicrob Agents Chemother 56: 1031-1041.

Rastrojo A., Carrasco-Ramiro F., Martín D., Crespillo A., Reguera RM., Aguado B., Requena JM. (2013) The transcriptome of Leishmania major in the axenic promastigote stage: transcript annotation and relative expression levels by RNAseq. BMC Genomics 14: 223.

Ravel C., Cortes S., Pratlong F., Morio F., Dedet JP., Campino L. (2006) First report of genetic hybrids between two very divergent Leishmania species: Leishmania infantum and Leishmania major. Int J Parasitol 36: 1383-1388.

Ravinder, Bhaskar, Gangwar S., Goyal N. (2012) Development of luciferase expressing Leishmania donovani axenic amastigotes as primary model for in vitro screening of antileishmanial compounds. Curr Microbiol 65: 696-700.

Reed SG., Coler RN., Campos-Neto A. (2003) Development of a leishmaniasis vaccine: the importance of MPL. Expert Rev Vaccines 2: 239-252.

Reguera RM., Balaña-Fouce R., Showalter M., Hickerson S., Beverley SM. (2009) Leishmania major lacking arginase (ARG) are auxotrophic for polyamines but retain infectivity to susceptible BALB/c mice. Mol Biochem Parasitol 165: 48-56.

Reguera RM., Calvo-Álvarez E., Álvarez-Velilla R., Balaña-Fouce R. (2014) Targetbased vs. phenotypic screenings in Leishmania drug discovery: A marriage of 
convenience or a dialogue of the deaf? Int J Parasitol Drugs Drug Resist http://dx.doi.org/10.1016/j.ijpddr.2014.05.001.

Reguera RM., Redondo CM., Gutierrez de Prado R., Pérez-Pertejo Y., Balaña-Fouce R. (2006) DNA topoisomerase I from parasitic protozoa: a potential target for chemotherapy. Biochim Biophys Acta 1759: 117-131.

Reiner NE., Ng W., McMaster WR. (1987) Parasite-accessory cell interactions in murine leishmaniasis. II. Leishmania donovani suppresses macrophage expression of class I and class II major histocompatibility complex gene products. J Immunol 138: 1926-1932.

Reithinger R., Davies CR. (1999) Is the domestic dog (Canis familiaris) a reservoir host of American cutaneous leishmaniasis? A critical review of the current evidence. Am J Trop Med Hyg 61: 530-541.

Reveiz L., Maia-Elkhoury AN., Nicholls RS., Romero GA., Yadon ZE. (2013) Interventions for American cutaneous and mucocutaneous leishmaniasis: a systematic review update. PLoS One 8: e61843.

Ritmeijer K., Dejenie A., Assefa Y., Hundie TB., Mesure J., Boots G., den Boer M., Davidson RN. (2006) A comparison of miltefosine and sodium stibogluconate for treatment of visceral leishmaniasis in an Ethiopian population with high prevalence of HIV infection. Clin Infect Dis 43: 357-364.

Ritter U., Moll H., Laskay T., Bröcker E., Velazco O., Becker I., Gillitzer R. (1996) Differential expression of chemokines in patients with localized and diffuse cutaneous American leishmaniasis. J Infect Dis 173: 699-709.

Roberts M., Stober C., Mckenzie A., Blackwell J. (2005) Interleukin-4 (IL-4) and IL10 collude in vaccine failure for novel exacerbatory antigens in murine Leishmania major infection. Infect Immun 73: 7620-7628.

Rochette A., Raymond F., Corbeil J., Ouellette M., Papadopoulou B. (2009) Wholegenome comparative RNA expression profiling of axenic and intracellular amastigote forms of Leishmania infantum. Mol Biochem Parasitol 165: 32-47.

Rockwell NC., Lagarias JC. (2010) A brief history of phytochromes. Chemphyschem 11: 1172-1180.

Rodrigues Júnior V., Da Silva JS., Campos-Neto A. (1992) Selective inability of spleen antigen presenting cells from Leishmania donovani infected hamsters to mediate specific T cell proliferation to parasite antigens. Parasite Immunol 14: 4958.

Rogers M., Kropf P., Choi B., Dillon R., Podinovskaia M., Bates P., Müller I. (2009) Proteophosophoglycans regurgitated by Leishmania-infected sand flies target the L-arginine metabolism of host macrophages to promote parasite survival. PLoS Pathog 5: 555-568.

Rogers MB., Downing T., Smith BA., Imamura H., Sanders M., Svobodova M., Volf P., Berriman M., Cotton JA., Smith DF. (2014) Genomic confirmation of hybridisation 
and recent inbreeding in a vector-isolated Leishmania population. PLoS Genet 10: e1004092.

Roy G., Dumas C., Sereno D., Wu Y., Singh AK., Tremblay MJ., Ouellette M., Olivier M., Papadopoulou B. (2000) Episomal and stable expression of the luciferase reporter gene for quantifying Leishmania spp. infections in macrophages and in animal models. Mol Biochem Parasitol 110: 195-206.

Sadlova J., Yeo M., Seblova V., Lewis MD., Mauricio I., Volf P., Miles MA. (2011) Visualisation of Leishmania donovani fluorescent hybrids during early stage development in the sand fly vector. PLoS One 6: e19851.

Saeij JP., Boyle JP., Grigg ME., Arrizabalaga G., Boothroyd JC. (2005) Bioluminescence imaging of Toxoplasma gondii infection in living mice reveals dramatic differences between strains. Infect Immun 73: 695-702.

Saenz RE., Paz H., Berman JD. (1990) Efficacy of ketoconazole against Leishmania braziliensis panamensis cutaneous leishmaniasis. Am J Med 89: 147-155.

Saravia NG., Escorcia B., Osorio Y., Valderrama L., Brooks D., Arteaga L., Coombs G., Mottram J., Travi BL. (2006) Pathogenicity and protective immunogenicity of cysteine proteinase-deficient mutants of Leishmania mexicana in non-murine models. Vaccine 24: 4247-4259.

Schmid-Hempel R., Salathé R., Tognazzo M., Schmid-Hempel P. (2011) Genetic exchange and emergence of novel strains in directly transmitted trypanosomatids. Infect Genet Evol 11: 564-571.

Schneider E., Hsiang YH., Liu LF. (1990) DNA topoisomerases as anticancer drug targets. Adv Pharmacol 21: 149-183.

Schröder J., Noack S., Marhöfer RJ., Mottram JC., Coombs GH., Selzer PM. (2013) Identification of semicarbazones, thiosemicarbazones and triazine nitriles as inhibitors of Leishmania mexicana cysteine protease CPB. PLoS One 8: e77460.

Scianimanico S., Desrosiers M., Dermine JF., Méresse S., Descoteaux A., Desjardins M. (1999) Impaired recruitment of the small GTPase rab7 correlates with the inhibition of phagosome maturation by Leishmania donovani promastigotes. Cell Microbiol 1: 19-32.

Secundino NF., de Freitas VC., Monteiro CC., Pires AC., David BA., Pimenta PF. (2012) The transmission of Leishmania infantum chagasi by the bite of the Lutzomyia longipalpis to two different vertebrates. Parasit Vectors 5: 20.

Selvapandiyan A., Dey R., Nylen S., Duncan R., Sacks DL., Nakhasi HL. (2009) Intracellular replication-deficient Leishmania donovani induces long lasting protective immunity against visceral leishmaniasis. J Immunol 183: 1813-1820.

Senkovich O., Schormann N., Chattopadhyay D. (2009) Structures of dihydrofolate reductase-thymidylate synthase of Trypanosoma cruzi in the folate-free state and in complex with two antifolate drugs, trimetrexate and methotrexate. Acta Crystallogr D Biol Crystallogr 65: 704-716. 
Sereno D., Cordeiro da Silva A., Mathieu-Daude F., Ouaissi A. (2007) Advances and perspectives in Leishmania cell based drug-screening procedures. Parasitol Int 56: 3-7.

Sereno D., Lemesre JL. (1997) Axenically cultured amastigote forms as an in vitro model for investigation of antileishmanial agents. Antimicrob Agents Chemother 41: 972-976.

Sereno D., Roy G., Lemesre JL., Papadopoulou B., Ouellette M. (2001) DNA transformation of Leishmania infantum axenic amastigotes and their use in drug screening. Antimicrob Agents Chemother 45: 1168-1173.

Shaner NC., Campbell RE., Steinbach PA., Giepmans BN., Palmer AE., Tsien RY. (2004) Improved monomeric red, orange and yellow fluorescent proteins derived from Discosoma sp. red fluorescent protein. Nat Biotechnol 22: 1567-1572.

Shaner NC., Steinbach PA., Tsien RY. (2005) A guide to choosing fluorescent proteins. Nat Methods 2: 905-909.

Sharrock RA. (2008) The phytochrome red/far-red photoreceptor superfamily. Genome Biol 9: 230.

Shcherbakova DM., Subach OM., Verkhusha VV. (2012) Red fluorescent proteins: advanced imaging applications and future design. Angew Chem Int 51: 1072410738.

Shcherbakova DM., Verkhusha VV. (2013) Near-infrared fluorescent proteins for multicolor in vivo imaging. Nat Methods 10: 751-754.

Shcherbo D., Merzlyak EM., Chepurnykh TV., Fradkov AF., Ermakova GV., Solovieva EA., Lukyanov KA., Bogdanova EA., Zaraisky AG., Lukyanov S., Chudakov DM. (2007) Bright far-red fluorescent protein for whole-body imaging. Nat Methods 4:741-746.

Shcherbo D., Murphy CS., Ermakova GV., Solovieva EA., Chepurnykh TV., Shcheglov AS., Verkhusha VV., Pletnev VZ., Hazelwood KL., Roche PM., Lukyanov S., Zaraisky AG., Davidson MW., Chudakov DM. (2009) Far-red fluorescent tags for protein imaging in living tissues. Biochem J 418: 567-574.

Shimomura O., Johnson FH., Saiga Y. (1962) Extraction, purification and properties of aequorin, a bioluminescent protein from the luminous hydromedusan, Aequorea. J Cell Comp Physiol 59: 223-239.

Shkrob MA., Yanushevich YG., Chudakov DM., Gurskaya NG., Labas YA., Poponov SY., Mudrik NN., Lukyanov S., Lukyanov KA. (2005) Far-red fluorescent proteins evolved from a blue chromoprotein from Actinia equina. Biochem J 392: 649-654.

Shu X., Royant A., Lin MZ., Aguilera TA., Lev-Ram V., Steinbach PA., Tsien RY. (2009) Mammalian expression of infrared fluorescent proteins engineered from a bacterial phytochrome. Science 324: 804-807.

Shweash M., Adrienne McGachy H., Schroeder J., Neamatallah T., Bryant CE., Millington O., Mottram JC., Alexander J., Plevin R. (2011) Leishmania mexicana 
promastigotes inhibit macrophage IL-12 production via TLR-4 dependent COX-2, iNOS and arginase-1 expression. Mol Immunol 48: 1800-1808.

Singh N. (2006) Drug resistance mechanisms in clinical isolates of Leishmania donovani. Indian J Med Res 123: 411-422.

Singh N., Gupta R., Jaiswal AK., Sundar S., Dube A. (2009) Transgenic Leishmania donovani clinical isolates expressing green fluorescent protein constitutively for rapid and reliable ex vivo drug screening. J Antimicrob Chemother 64: 370-374.

Sinha PK., van Griensven J., Pandey K., Kumar N., Verma N., Mahajan R., Kumar P., Kumar R., Das P., Mitra G., Flevaud L., Ferreyra C., Remartinez D., Pece M., Palma PP. (2011) Liposomal amphotericin B for visceral leishmaniasis in human immunodeficiency virus-coinfected patients: 2-year treatment outcomes in Bihar, India. Clin Infect Dis 53: e91-8.

Siqueira-Neto JL., Moon S., Jang J., Yang G., Lee C., Moon HK., Chatelain E., Genovesio A., Cechetto J., Freitas-Junior LH. (2012) An image-based high-content screening assay for compounds targeting intracellular Leishmania donovani amastigotes in human macrophages. PLoS Negl Trop Dis 6: e1671.

Souza-Lemos C., De-Campos SN., Teva A., Porrozzi R., Grimaldi G Jr. (2011) In situ characterization of the granulomatous immune response with time in non-healing lesional skin of Leishmania braziliensis-infected Rhesus macaques (Macaca mulatta). Vet Immun Immunopathol 142: 147-155.

Späth GF., Lye LF., Segawa H., Sacks DL., Turco SJ., Beverley SM. (2003) Persistence without pathology in phosphoglycan-deficient Leishmania major. Science 301: 1241-1243.

Späth GF., Lye LF., Segawa H., Turco SJ., Beverley SM. (2004) Identification of a compensatory mutant (lpg2-REV) of Leishmania major able to survive as amastigotes within macrophages without LPG2-dependent glycoconjugates and its significance to virulence and immunization strategies. Infect Immun 72: 36223627.

Strack RL., Hein B., Bhattacharyya D., Hell SW., Keenan RJ., Glick BS. (2009) A rapidly maturing far-red derivative of DsRed-Express2 for whole-cell labeling. Biochemistry 48: 8279-8281.

Sundar S., Agrawal N., Arora R., Agarwal D., Rai M., Chakravarty J. (2009) Shortcourse paromomycin treatment of visceral leishmaniasis in India: 14-day vs 21day treatment. Clin Infect Dis 49: 914-918.

Sundar S., Chakravarty J., Agarwal D., Rai M., Murray HW. (2010) Single-dose liposomal amphotericin B for visceral leishmaniasis in India. N Engl J Med. 362: 504-512.

Sundar S., Jha TK., Thakur CP., Mishra M., Singh VP., Buffels R. (2002) Single-dose liposomal amphotericin B in the treatment of visceral leishmaniasis in India: a multicenter study. Clin Infect Dis 37: 800-804. 
Suzuki E., Tanaka AK., Toledo MS., Takahashi HK., Straus AH. (2002) Role of betaD-galactofuranose in Leishmania major macrophage invasion. Infect Immun 70: 6592-6596.

Szatkiewicz JP., Beane GL., Ding Y., Hutchins L., Pardo-Manuel de Villena F., Churchill GA. (2008) An imputed genotype resource for the laboratory mouse. Mamm Genome 19: 199-208.

Tabatabaee PA., Abolhassani M., Mahdavi M., Nahrevanian H., Azadmanesh K. (2011) Leishmania major: secreted antigens of Leishmania major promastigotes shift the immune response of the C57BL/6 mice toward Th2 in vitro. Exp Parasitol 127: 46-51.

Tait A. (1980) Evidence for diploidy and mating in trypanosomes. Nature 287: 536-538.

Tait A. (1983) Sexual processes in the kinetoplastida. Parasitology 86: 29-57.

Tait A., Barry JD., Wink R., Sanderson A., Crowe JS. (1985) Enzyme variation in T. brucei ssp. II. Evidence for T. $b$. rhodesiense being a set of variants of T. $b$. brucei. Parasitology 90: 89-100.

Teicher AB. (2008) Next generation topoisomerase I inhibitors: Rationale and biomarker strategies. Biochem Pharmac 75: 1262-1271.

Telleria EL., de Araújo AP., Secundino NF., d'Avila-Levy CM., Traub-Csekö YM. (2010) Trypsin-like serine proteases in Lutzomyia longipalpis: expression, activity and possible modulation by Leishmania infantum chagasi. PLoS One 5: e10697.

Telleria EL., Sant'Anna MR., Alkurbi MO., Pitaluga AN., Dillon RJ., Traub-Csekö YM. (2013) Bacterial feeding, Leishmania infection and distinct infection routes induce differential defensin expression in Lutzomyia longipalpis. Parasit Vectors 6: 12.

Thalhofer CJ., Graff JW., Love-Homan L., Hickerson SM., Craft N., Beverley SM., Wilson ME. (2010) In vivo imaging of transgenic Leishmania parasites in a live host. J Vis Exp pii: 1980.

Tibayrenc M., Ayala FJ. (1987) Trypanosoma cruzi populations: more clonal than sexual. Parasitol Today 3: 189-190.

Tibayrenc M., Ayala FJ. (2013) How clonal are Trypanosoma and Leishmania? Trends Parasitol 29: 264-269.

Tibayrenc M., Echalar L., Dujardin JP., Poch O., Desjeux P. (1984) The microdistribution of isoenzymic strains of Trypanosoma cruzi in southern Bolivia; new isoenzyme profiles and further arguments against Mendelian sexuality. Trans R Soc Trop Med Hyg 78: 519-525.

Tibayrenc M., Kjellberg F., Ayala FJ. (1990) A clonal theory of parasitic protozoa: the population structures of Entamoeba, Giardia, Leishmania, Naegleria, Plasmodium, Trichomonas, and Trypanosoma and their medical and taxonomical consequences. Proc Natl Acad Sci USA 87: 2414-2418. 
Trouiller P., Olliaro PL. (1999) Drug development output: what proportion for tropical diseases? Lancet 354: 164.

Troy T., Jekic-McMullen D., Sambucetti L., Rice B. (2004) Quantitative comparison of the sensitivity of detection of fluorescent and bioluminescent reporters in animal models. Mol Imaging 3: 9-23.

Tsien R.Y. (1998) The green fluorescent protein. Annu Rev Biochem 67: 509-544.

Uzonna JE., Späth GF., Beverley SM., Scott P. (2004) Vaccination with phosphoglycan-deficient Leishmania major protects highly susceptible mice from virulent challenge without inducing a strong Th1 response. J Immunol 172: 37933797.

Villa H., Otero-Marcos AR., Reguera RM., Balaña-Fouce R., García- Estrada C., PérezPertejo Y., Tekwani BL., Myler PJ., Stuart KD., Bjornsti MA., Ordóñez D. (2003) A novel active DNA topoisomerase I in Leishmania donovani. J Biol Chem 278: 35213526.

Vinet AF., Fukuda M., Turco SJ., Descoteaux A. (2009) The Leishmania donovani lipophosphoglycan excludes the vesicular proton-ATPase from phagosomes by impairing the recruitment of synaptotagmin V. PLoS Pathog 5: e1000628.

Volf P., Benkova I., Myskova J., Sadlova J., Campino L., Ravel C. (2007) Increased transmission potential of Leishmania major/Leishmania infantum hybrids. Int J Parasitol 37: 589-593.

Vouldoukis I., Drapier JC., Nüssler AK., Tselentis Y., Da Silva O., Gentilini M., Mossalayi DM., Monjour L., Dugas B. (1996) Canine visceral leishmaniasis: successful chemotherapy induces macrophage antileishmanial activity via the Larginine nitric oxide pathway. Antimicrob Agents Chemother 40: 253-256.

Wagner JR., Zhang J., von Stetten D., Günther M., Murgida DH., Mroginski MA., Walker JM., Forest KT., Hildebrandt P., Vierstra RD. (2008) Mutational analysis of Deinococcus radiodurans bacteriophytochrome reveals key amino acids necessary for the photochromicity and proton exchange cycle of phytochromes. J Biol Chem 283: $12212-12226$.

Walliker D., Quakyi IA., Wellems TE., McCutchan TF., Szarfman A., London WT., Corcoran LM., Burkot TR., Carter R. (1987) Genetic analysis of the human malaria parasite Plasmodium falciparum. Science 236: 1661-1666.

Walters LL., Irons KP., Modi GB., Tesh RB. (1992) Refractory barriers in the sand fly Phlebotomus papatasi (Diptera: Psychodidae) to infection with Leishmania panamensis. Am J Trop Med Hyg 46: 211-228.

Wang L., Jackson WC., Steinbach PA., Tsien RY. (2004) Evolution of new nonantibody proteins via iterative somatic hypermutation. Proc Natl Acad Sci USA 101: $16745-16749$.

Weingärtner A., Kemmer G., Müller FD., Zampieri RA., Gonzaga dos Santos M., Schiller J., Pomorski TG. (2012) Leishmania promastigotes lack phosphatidylserine 
but bind annexin $\mathrm{V}$ upon permeabilization or miltefosine treatment. PLoS One 7: e42070.

Weissleder R., Ntziachristos V. (2003) Shedding light onto live molecular targets. Nat Med 9: 123-128.

Wenzel UA., Bank E., Florian C., Förster S., Zimara N., Steinacker J., Klinger M., Reiling N., Ritter U., van Zandbergen G. (2012) Leishmania major parasite stagedependent host cell invasion and immune evasion. FASEB J 26: 29-39.

Williams D., Mullen AB., Baillie AJ., Carter KC. (1998) Comparison of the efficacy of free and non-ionic-surfactant vesicular formulations of paromomycin in a murine model of visceral leishmaniasis. J Pharm Pharmacol 50: 1351-1356.

Wilson J., Huynh C., Kennedy KA., Ward DM., Kaplan J., Aderem A., Andrews NW. (2008) Control of parasitophorous vacuole expansion by LYST/Beige restricts the intracellular growth of Leishmania amazonensis. PLoS Pathog 4: e1000179.

Wilson ME., Jeronimo SMB., Pearson RD. (2005) Immunopathogenesis of infection with the visceralizing Leishmania species. Microb Pathog 38: 147-160.

Yeates C. (2002) Sitamaquine (GlaxoSmithKline/Walter Reed Army Institute). Curr Opin Investig Drugs 3: 1446-1452.

Zacharias DA., Tsien RY. (2006) Molecular biology and mutation of green fluorescent protein. Methods Biochem Anal 47: 83-120.

Zacharias DA., Violin JD., Newton AC., Tsien RY. (2002) Partitioning of lipidmodified monomeric GFPs into membrane microdomains of live cells. Science 296: 913-916.

Zhu AX., Ready N., Clark JW., Safran H., Amato A., Salem N., Pace S., He X., Zvereva N., Lynch TJ., Ryan DP., Supko JG. (2009) Phase I and pharmacokinetic study of gimatecan given orally once a week for 3 of 4 weeks in patients with advanced solid tumors. Clin Cancer Res 15: 374-381. 
